ALBERT R. MANN LIBRARY

AT

CORNELL UNIVERSITY

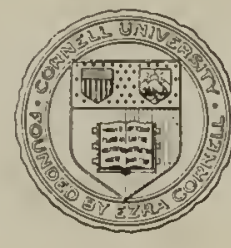

THE GIFT OF

Isabel Zucker

class ' 26 
$8 j \sec$

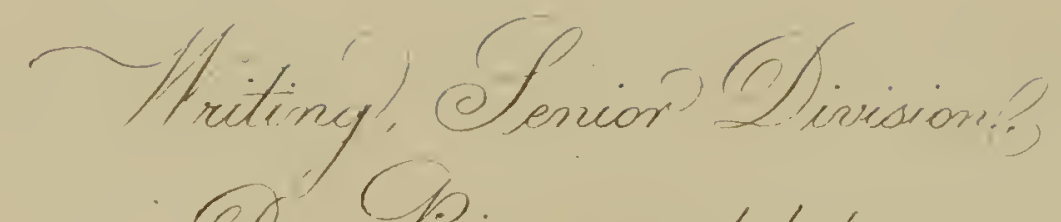

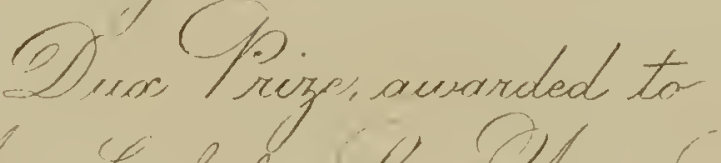

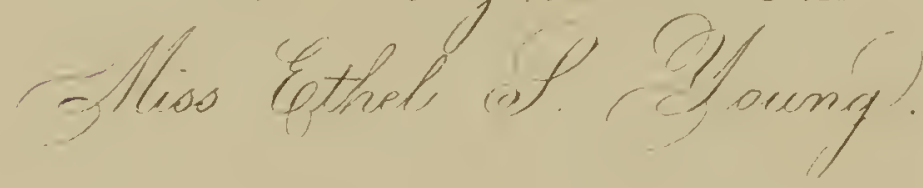

Mir. Hi. Andersomp. Niastor.

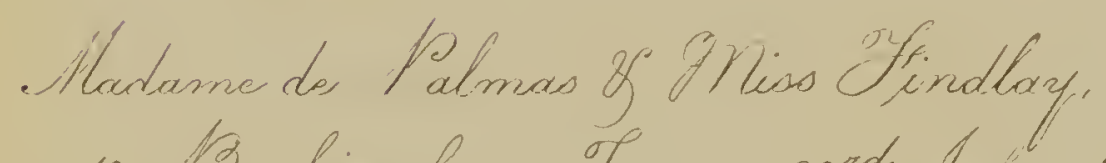

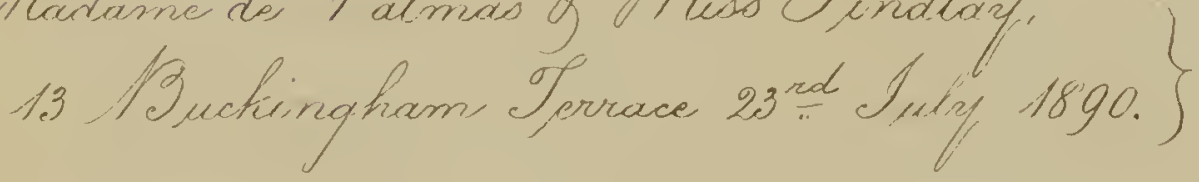




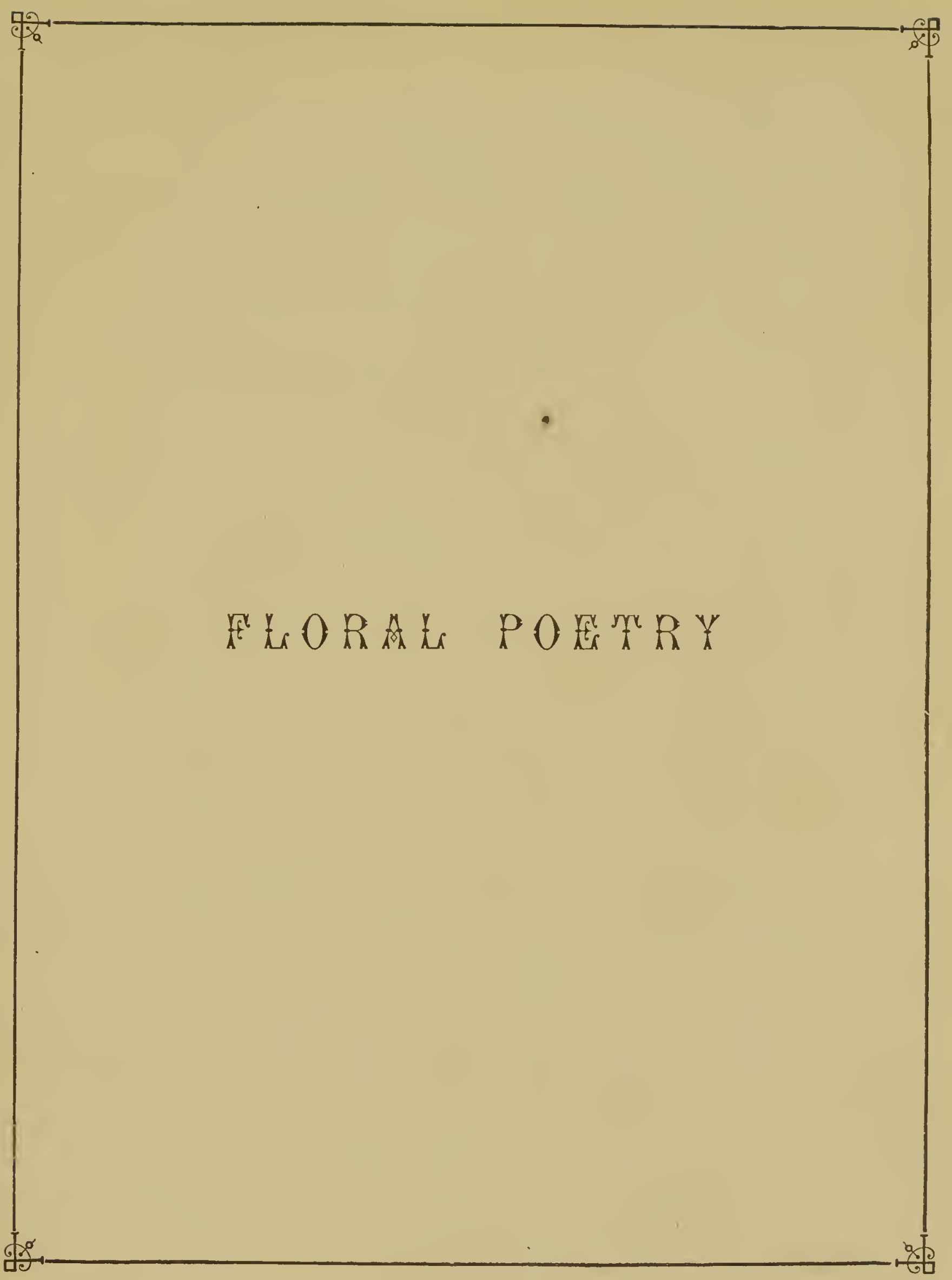






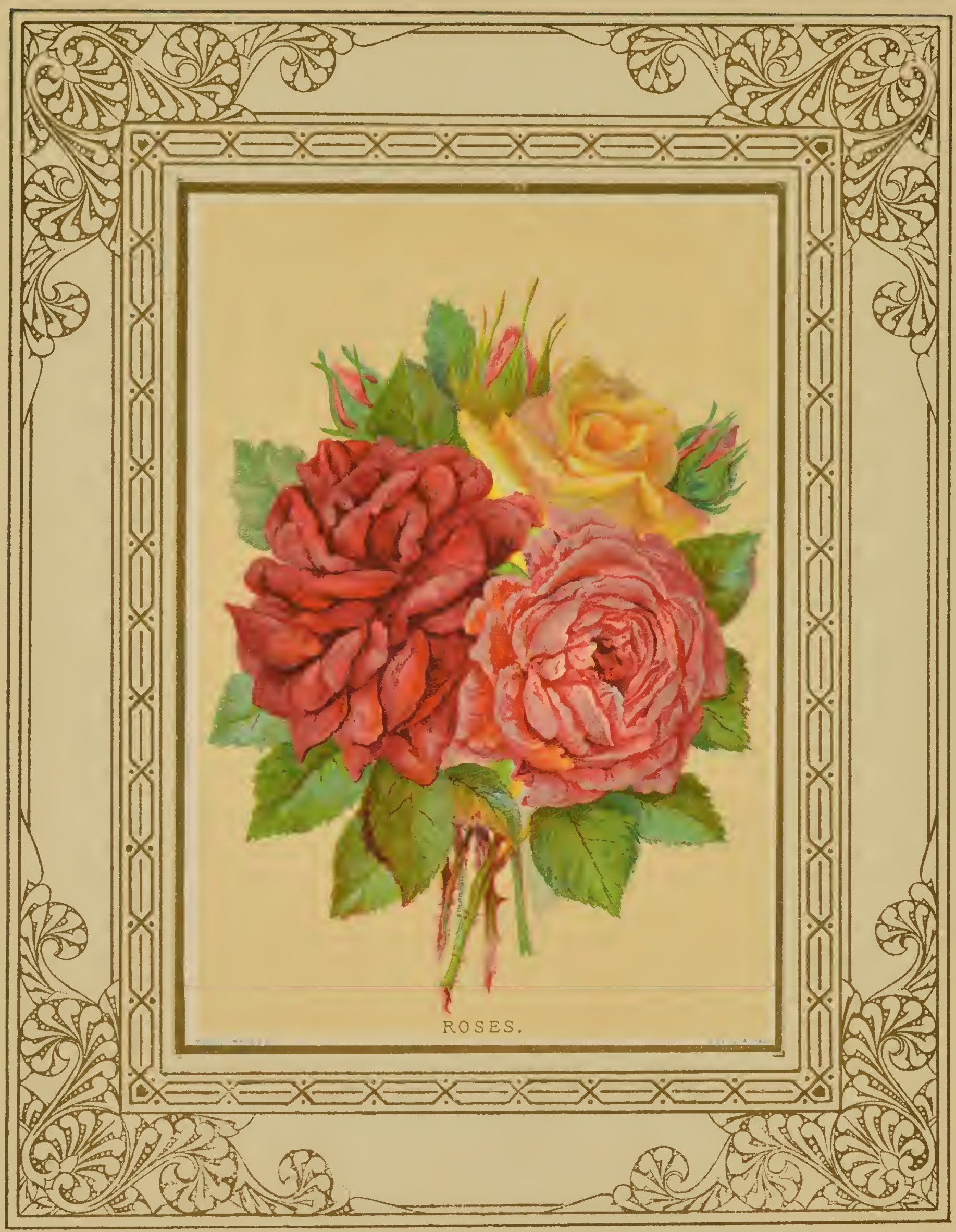




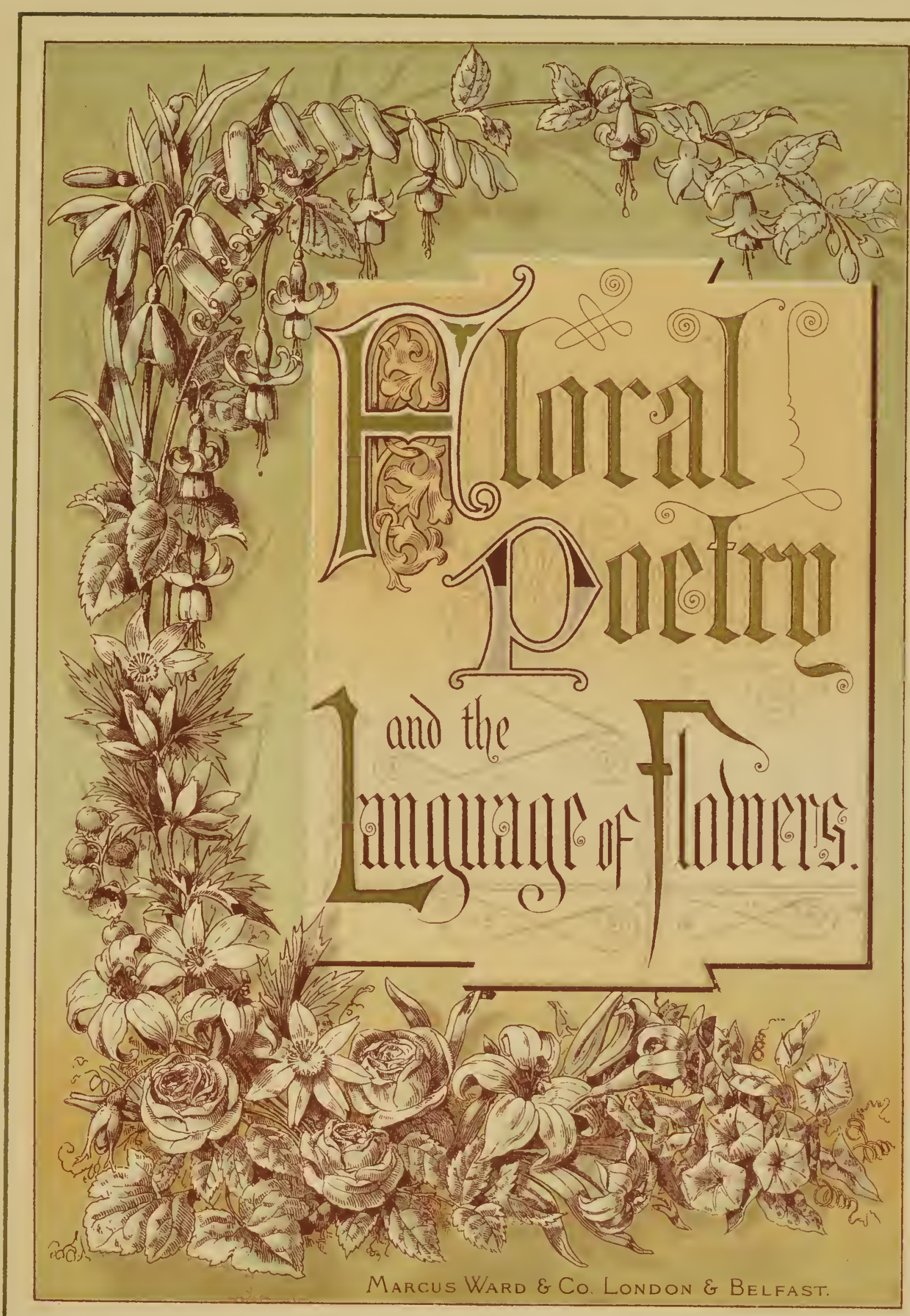





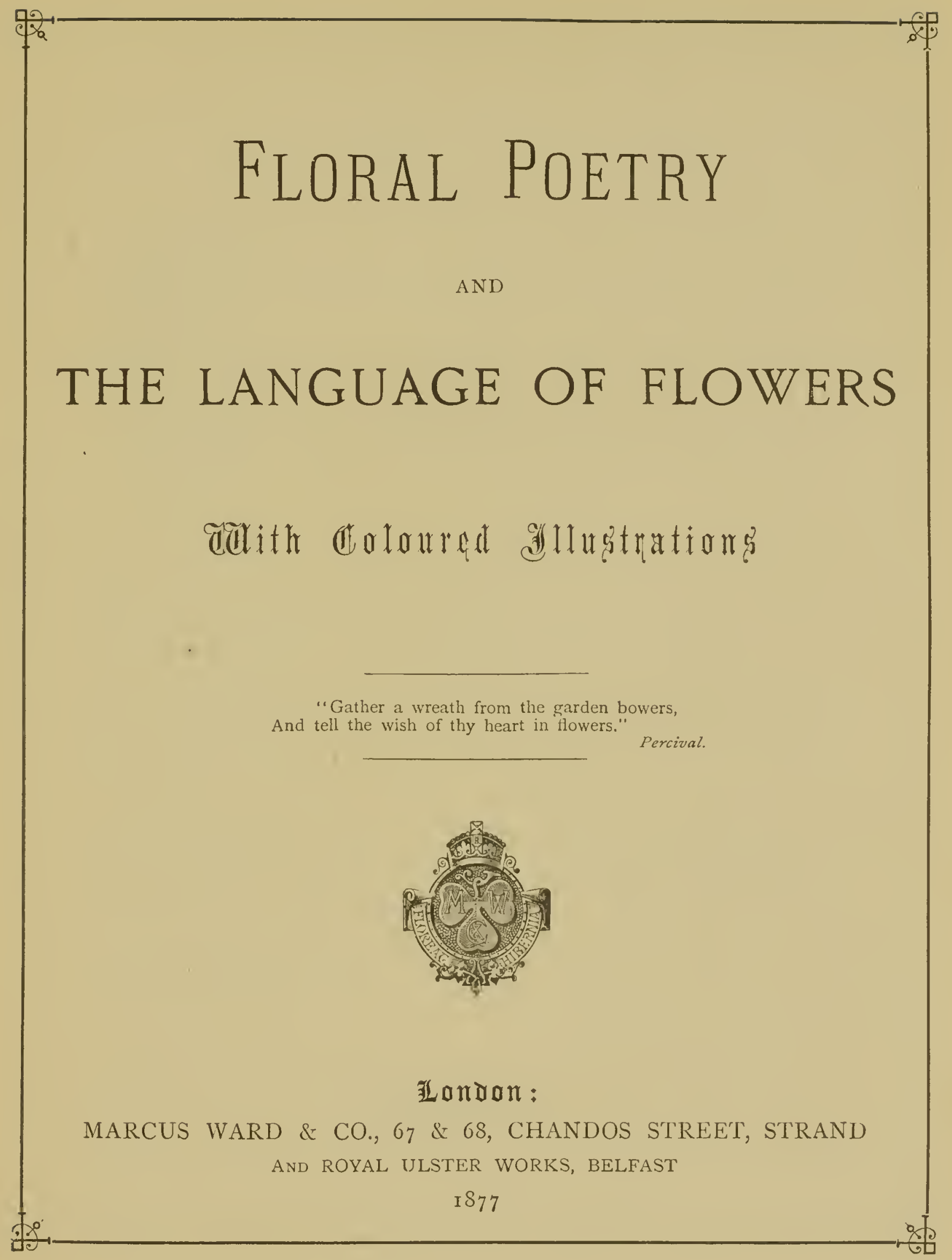




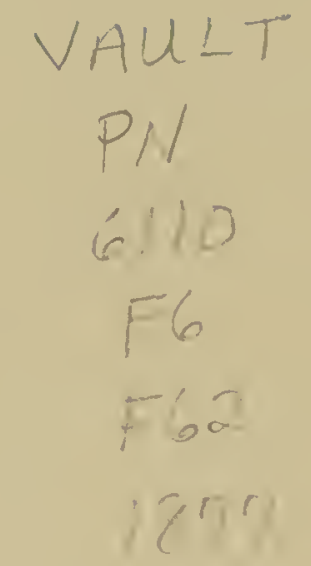

PRINTED BY

MARCUS WARD AND CO.

ROYAL ULSTER WORKS

belfast 


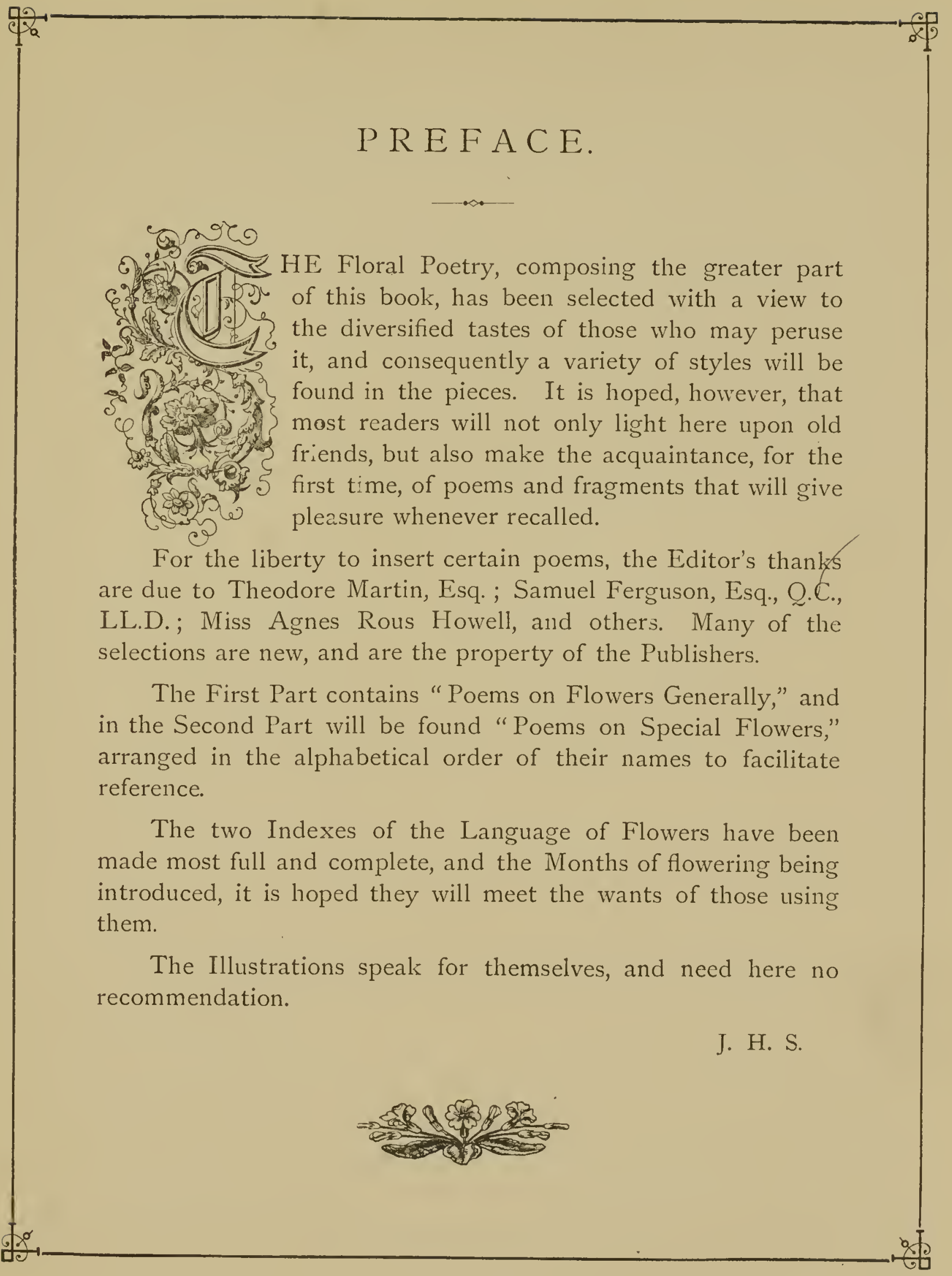





\section{List of Authors.}

Allingham, W., 57.

Anonymous, 24, 32, 50, 62, 76, 8I, 98, го3, го7, го8, гі6, гі9, г 2 I, г22, г 28 , 1 38, I 83, I 88, I 93, I 98, 200, 225, 229.

ARnOLd, EDWIN, 67.

BARTON, BERNARD，79，I27， I52， I 55, I72, 232.

BEAUMONT AND FleTCHER, I 76.

BIDLAKE, I 68.

Blessington, Countess of, I 24.

BOWLES, C., 242.

BOWRING, I 78 .

BROWNE, I6, I I 3 .

Browning, Elizabeth B., ili, i94.

BRYANT, WILliaM C., 64, II2, I37, 234.

BURNS, 25, 89, I6I, I79.

BYRON, I 39.

CAMPBell, 60.

CAREw, ThOMAS, I65.

CASIMIR, I23.

Chaucer, 88 .

Clare, John, 6i, ioi, i6 I.

Coleridge, Samuel T., i 33 .

COOK, ElizA, 70, 73.

CORNWALL, BARRY, 49, I53, 222.

COWVPER, 39, 59, I 36.

DANA, RICHARD H., 53 .

DANIEL, I 97.

DRAYTON, I 4 .

Elliott, 48, 49, 72, 2 I2.

FERGUSON, SAMUEL, II 5 .
Fletcher, Giles, I 38 .

GAY, I 5 O.

GIFFORD, WILLIAM, 236.

Gillespie, Thomas, i 86 .

Gillet, Thomas, i Io, I2O, I 43.

GOOD, J. MASON, 96.

GoULD, H. F., I 84 .

Gover, Rev. Canon, i93.

G. W., 2 I 6.

Hemans, Mrs., 28, 33，38，44， I26， I 48, I 54, I 80, 192.

HERRICK, 45, 9I, I48, I6o.

HINCKS, REV. T., 2 I9.

HOFFMAN, 9, 63, $20 \mathrm{I}$.

HOLMES, O. W., I 46.

HOOD, I74.

Howell, AgNes R., I44, 219.

Howite, Mary, i $8,78$.

HUNTER, MRS., I63.

HURDIS, JAMES, I 45.

JEWSBURY, Miss, 46.

JONSON, BEN, 149.

KEATS, 20, 65, i $5 \mathrm{I}$.

KEBLE, I $90,220$.

LANDON, L. E., 27, 68, 230.

LONGFELLOW, IO.

MANT, BISHOP, IO2, I4O.

MARTIN, THEODORE, IO4, I 89, 228.

MiLTON, I 8, 66.

MONTGOMERY, 87, 92, I 32, 226, 227.

MoORE, 37, 54, I 3 I , I 77, I 87, 2 I 5. 


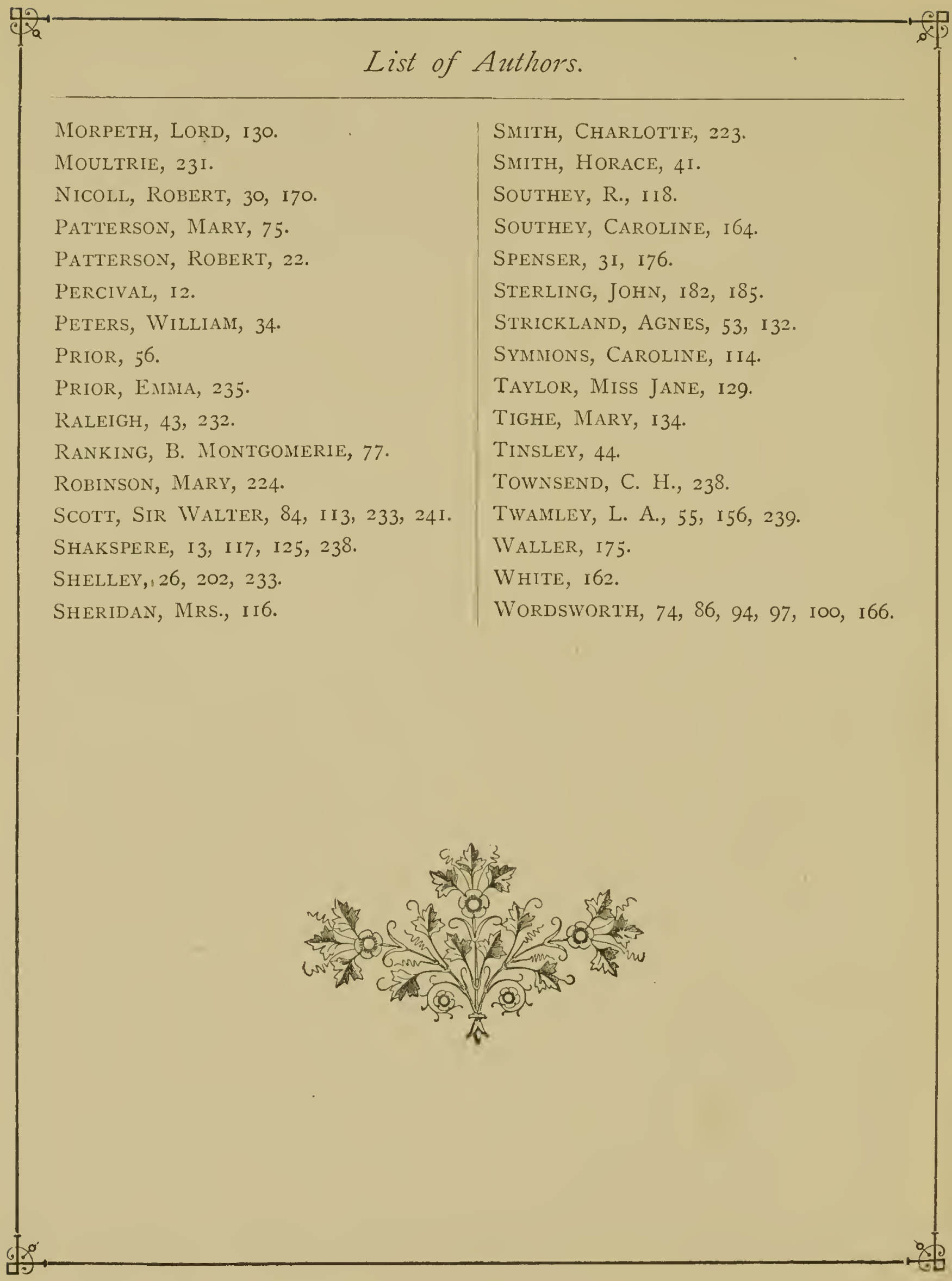




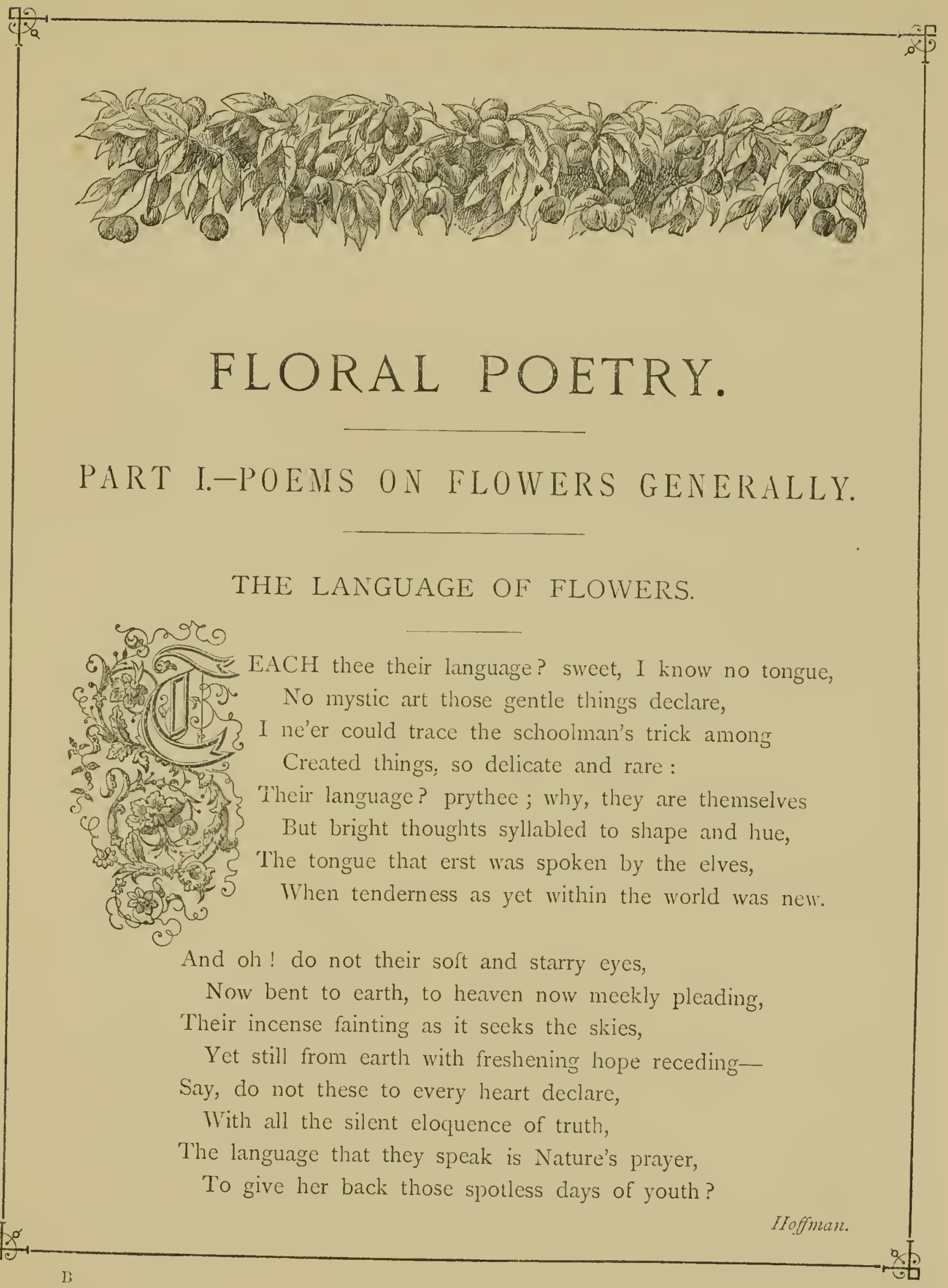




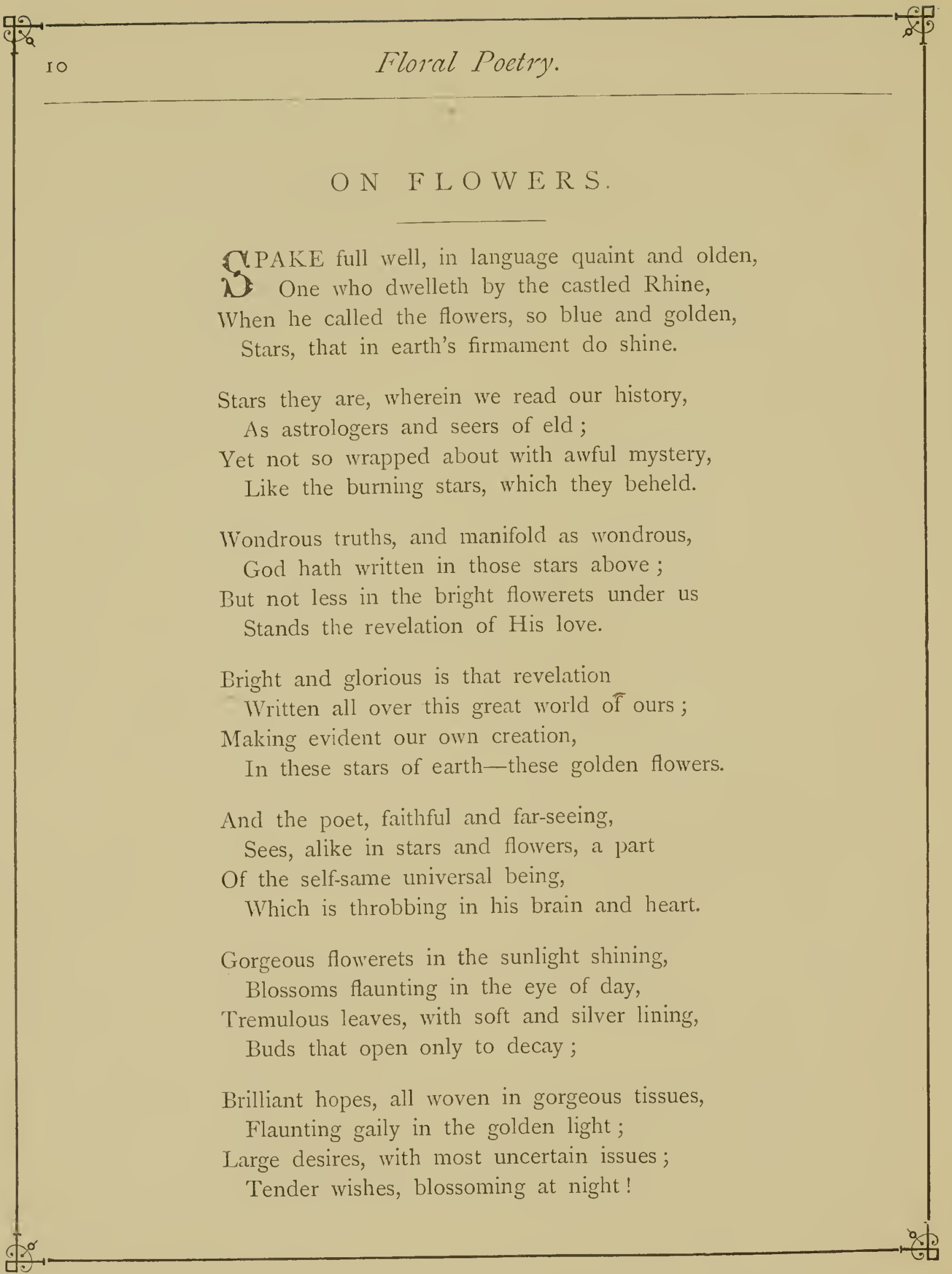


These in flowers and men are more than seeming;

Workings are they of the self-same powers,

Which the poet, in no idle dreaming,

Seeth in himself and in the flowers.

Everywhere about us are they glowing, Some like stars, to tell us Spring is born;

Others, their blue eyes with tears o'erflowing,

Stand like Ruth amid the golden corn;

Not alone in Spring's armorial bearing,

And in Sunmer's green emblazoned field,

But in the arms of brave old Autumn's wearing,

In the centre of his brazen shield:

Not alone in meadows and green alleys,

On the mountain-top, and by the brink

Of sequestered pools in woodland valleys,

Where the slaves of Nature stoop to drink;

Not alone in her vast dome of glory,

Not on graves of bird and beast alone,

But on old cathedrals, high and hoary,

On the tombs of heroes, carved in stone;

In the cottage of the rudest peasant,

In ancestral homes, whose crumbling towers,

Speaking of the Past unto the Present,

Tell us of the ancient games of Flowers;

In all places, then, and in all seasons,

Flowers expand their light and soul-like wings,

Teaching us, by most persuasive reasons,

How akin they are to human things.

And with child-like, credulous affection,

We behold their tender buds expand;

Emblems of our own great resurrection,

Emblems of the bright and better land.

Longfellow. 


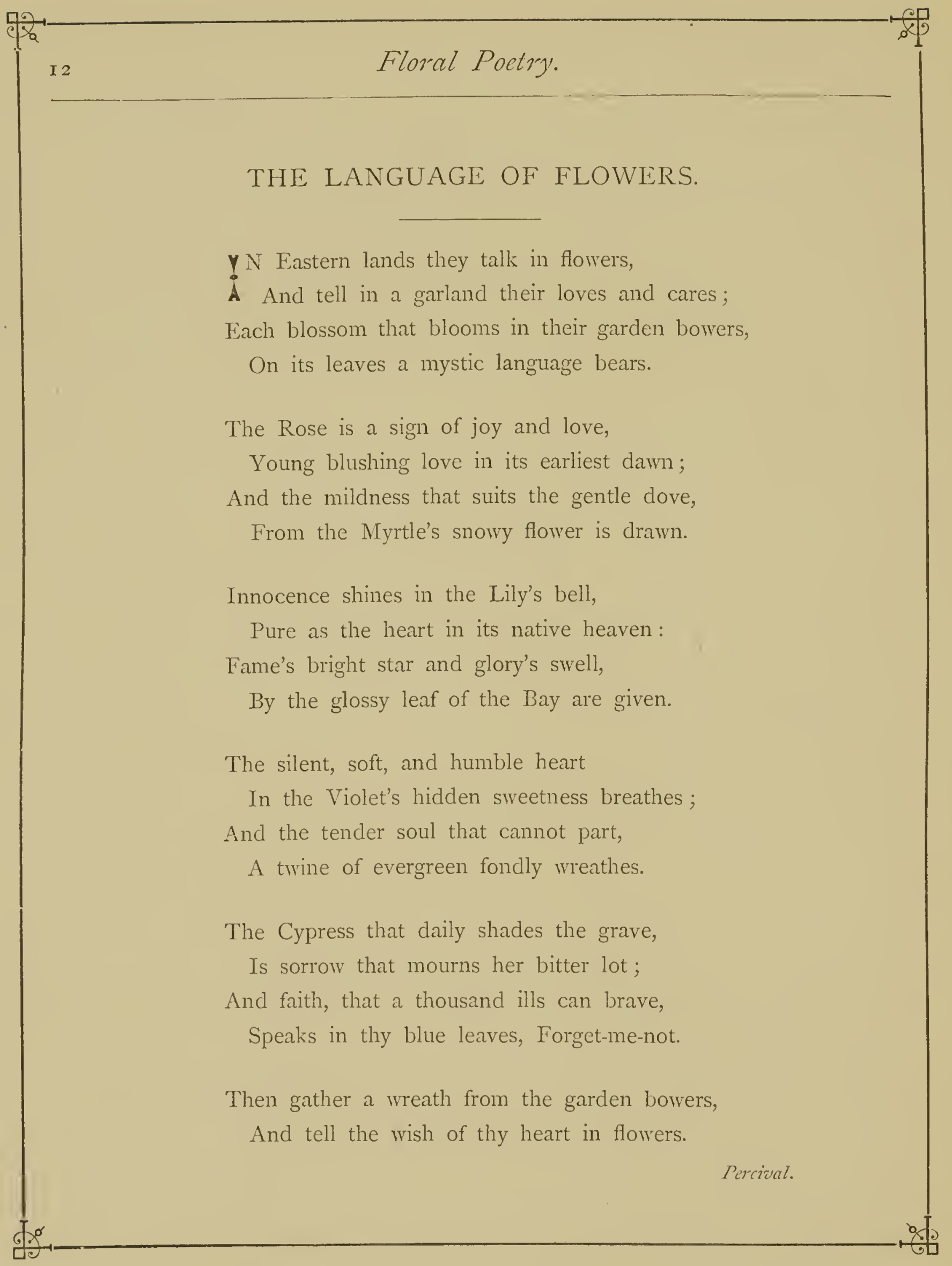




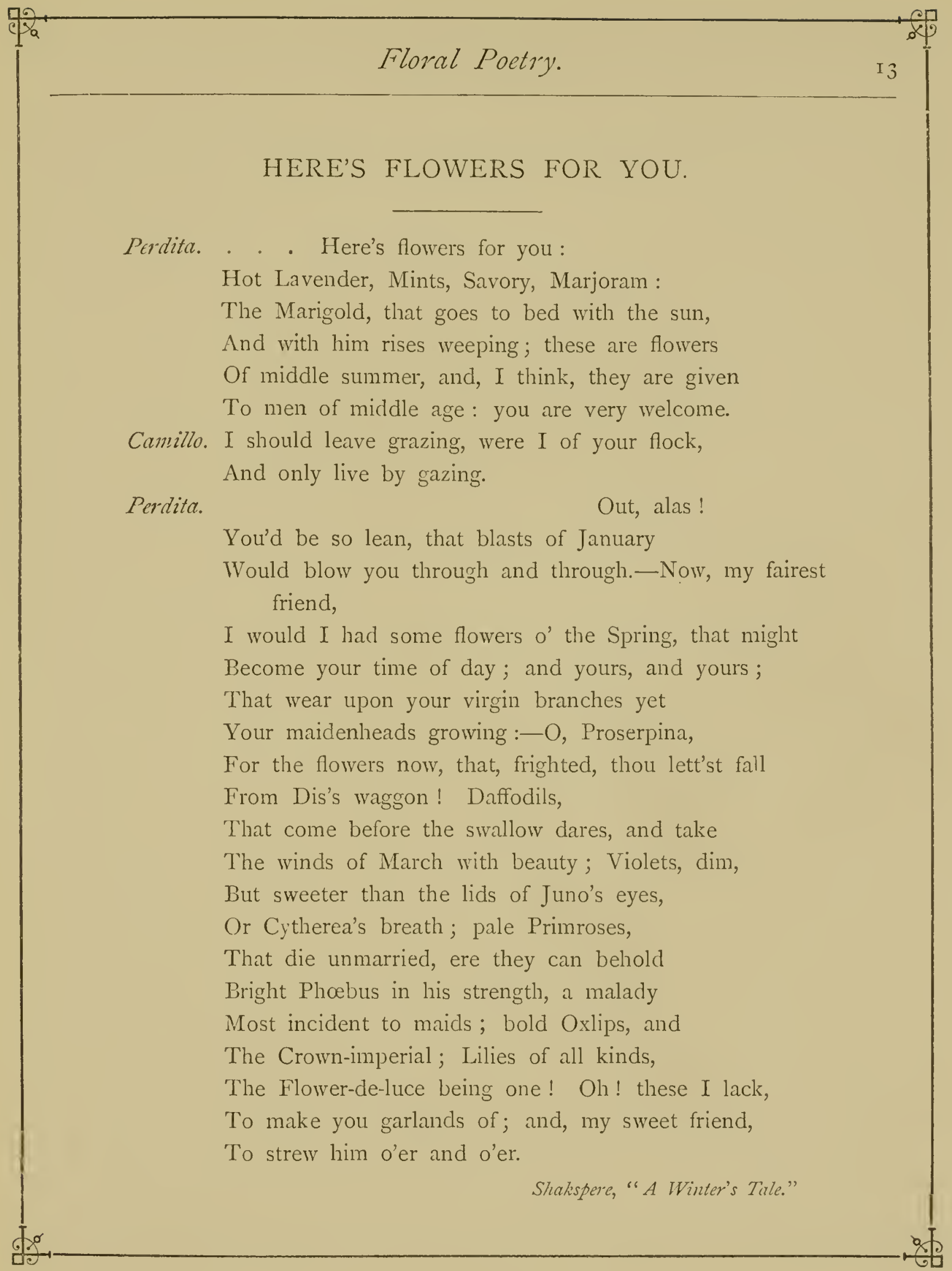




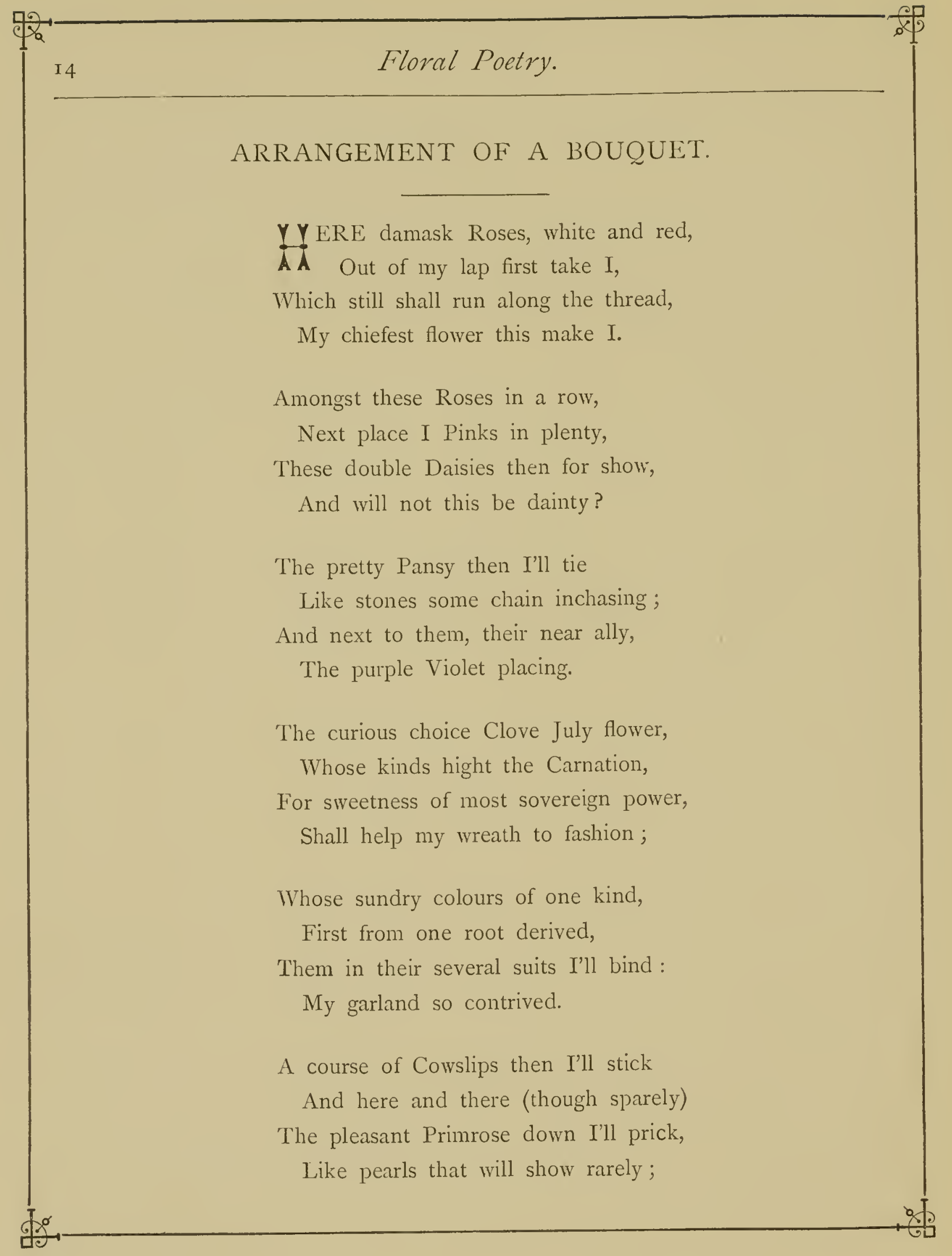




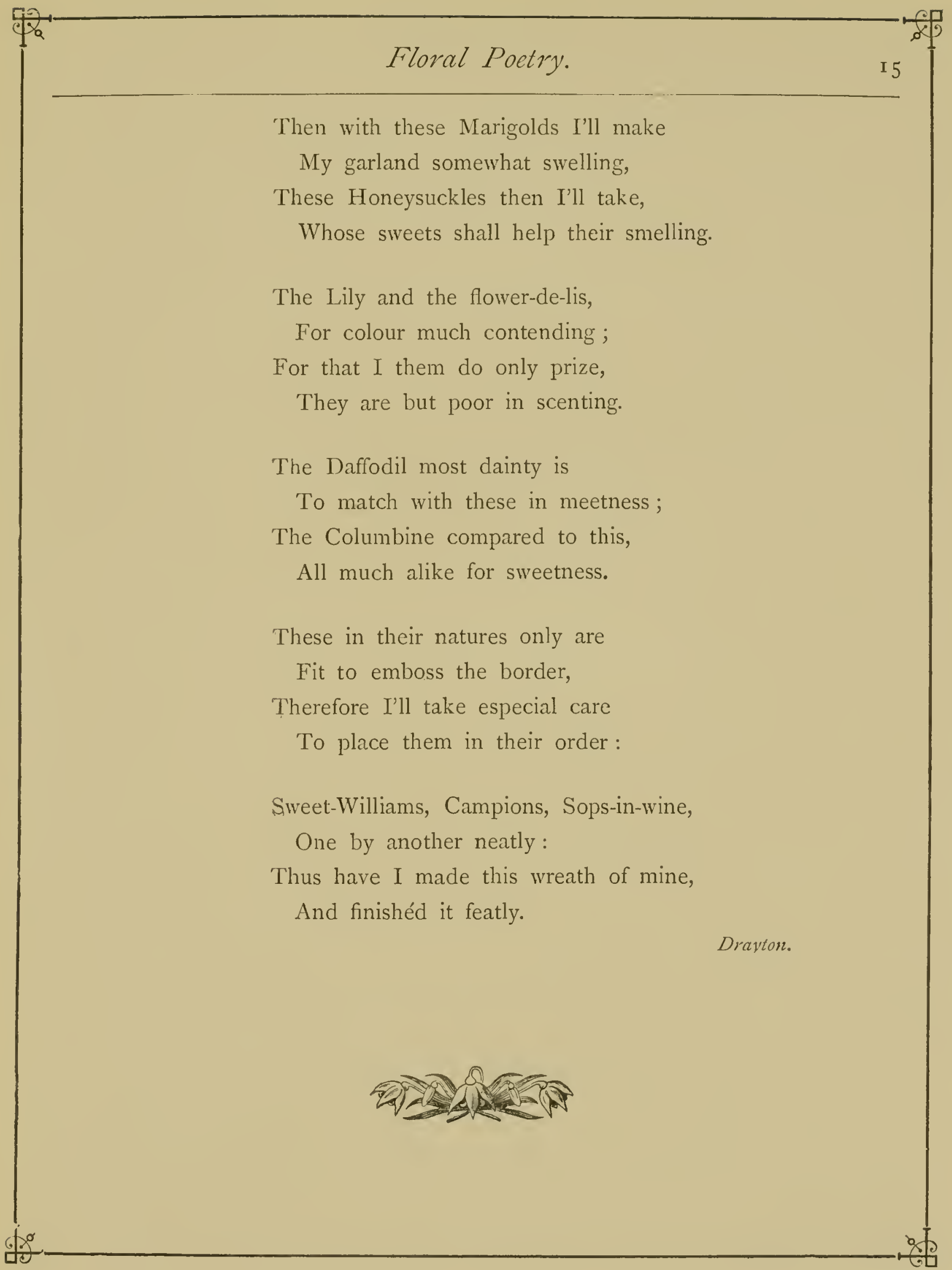




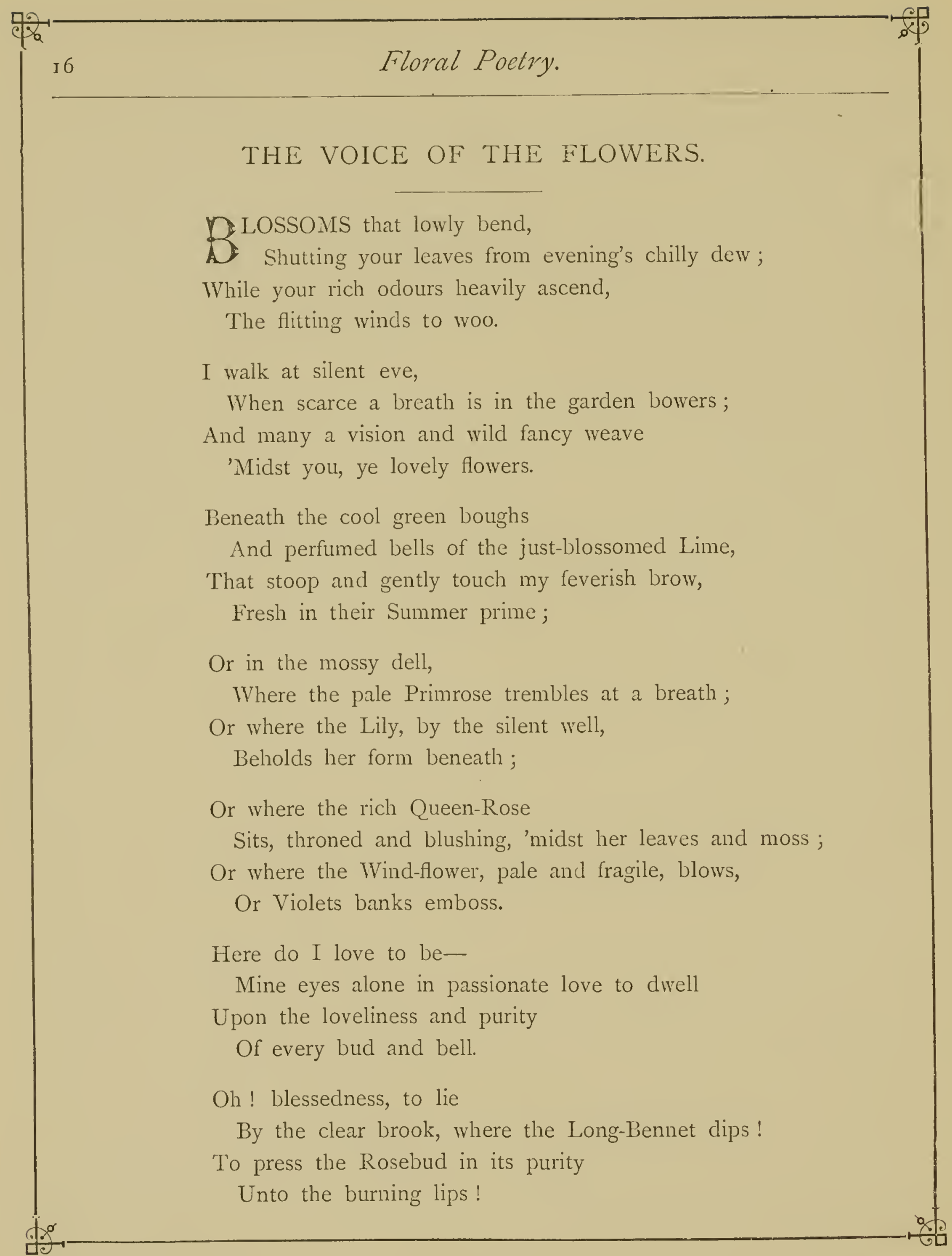




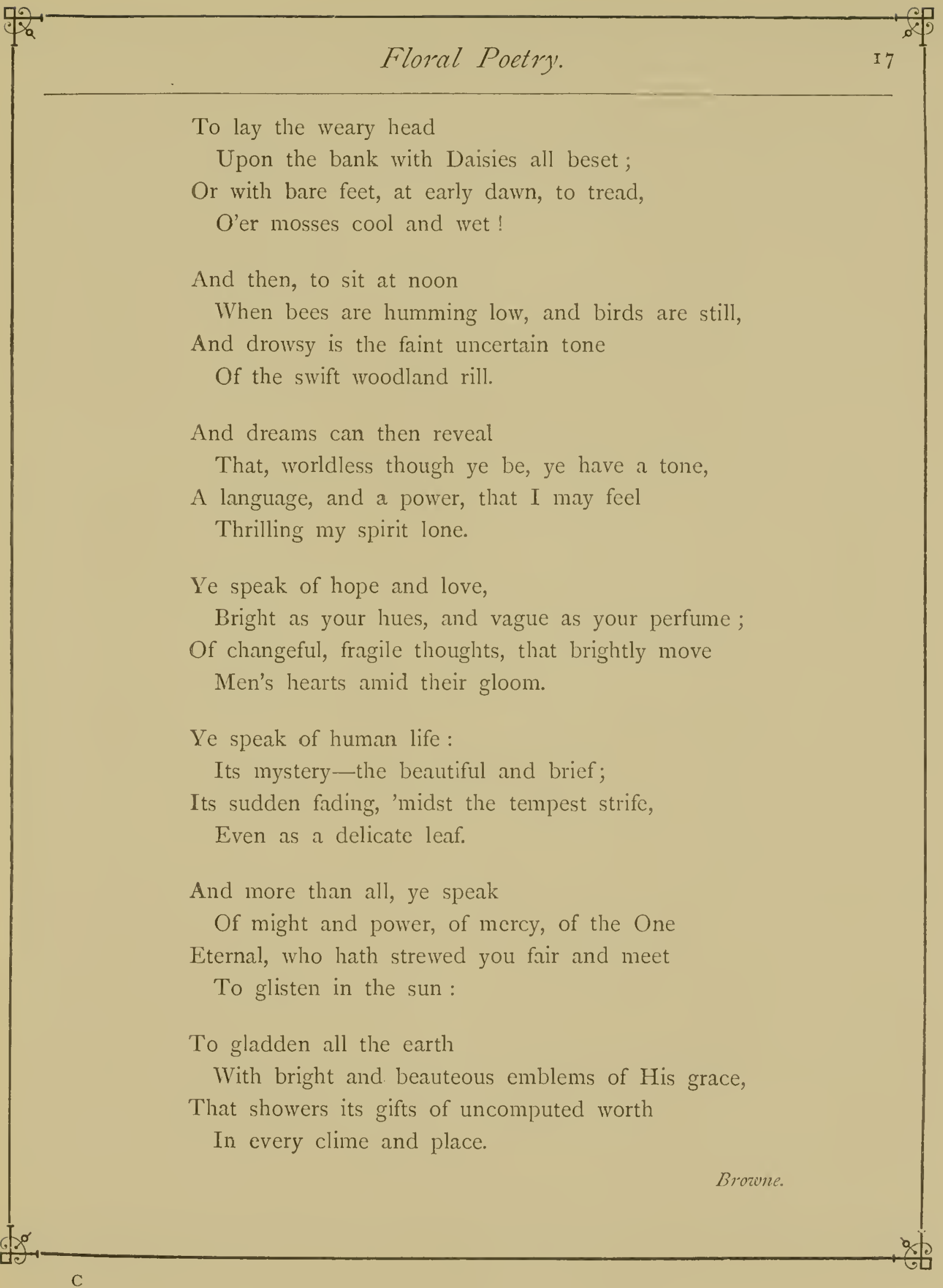




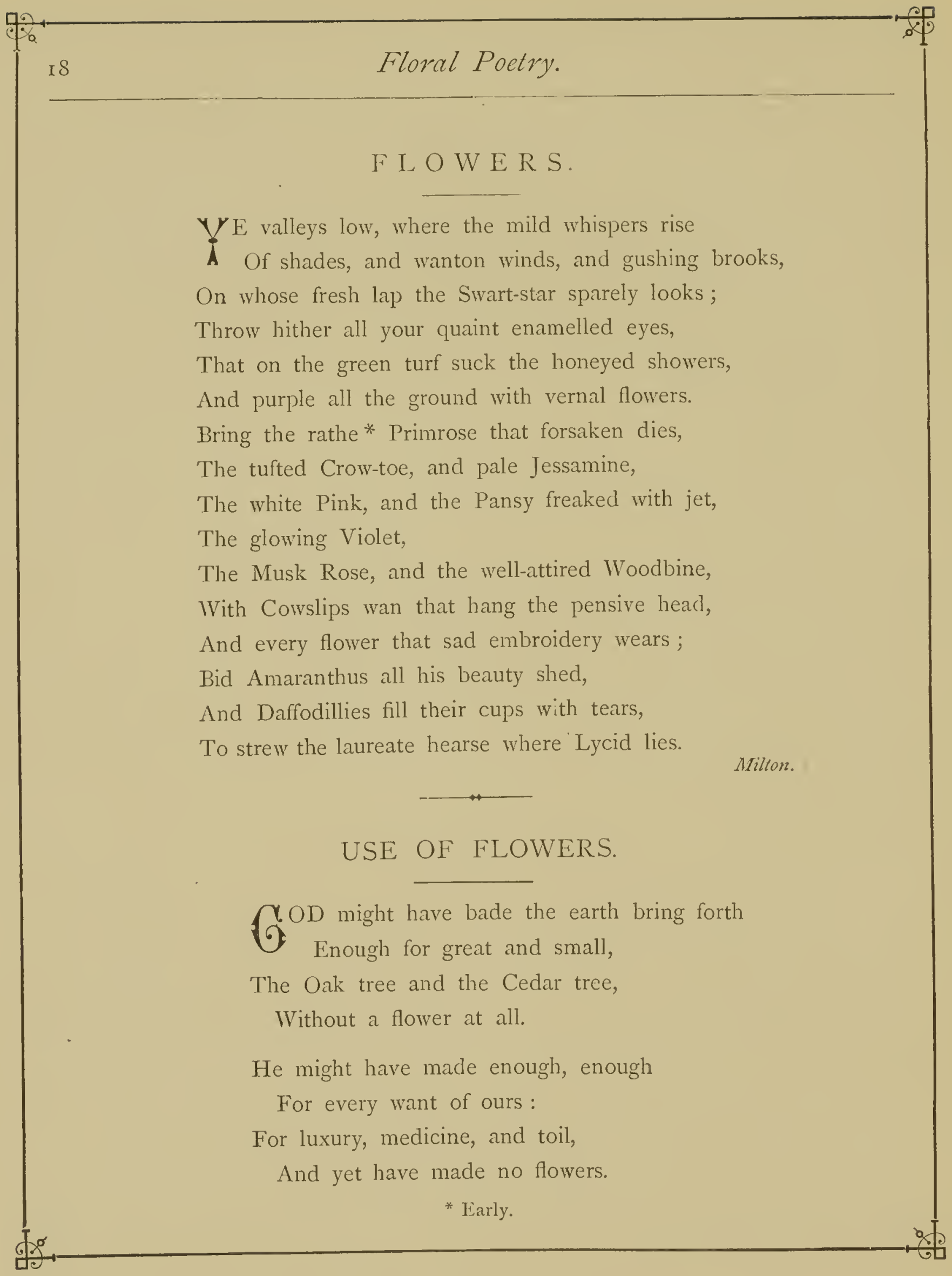




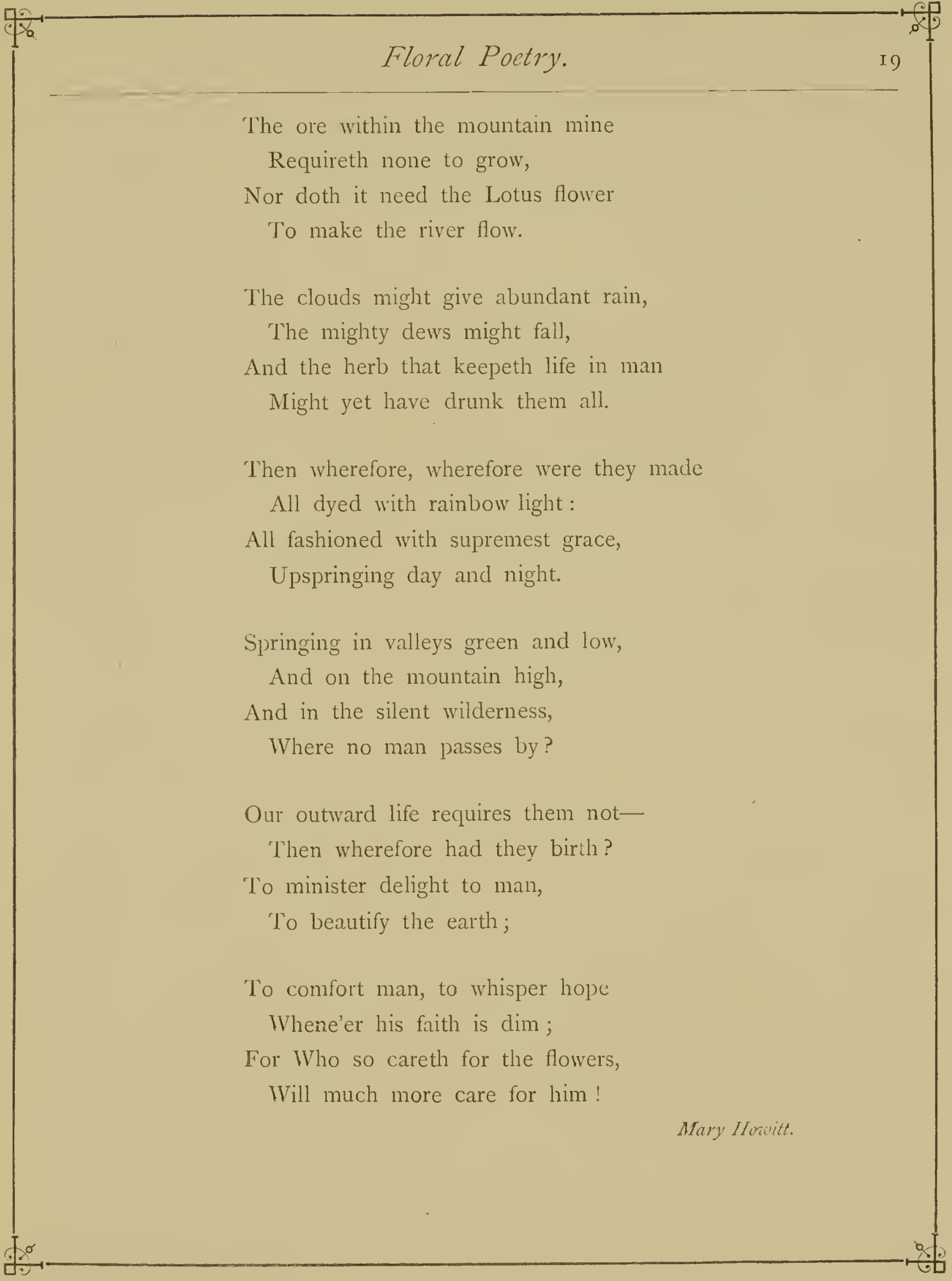




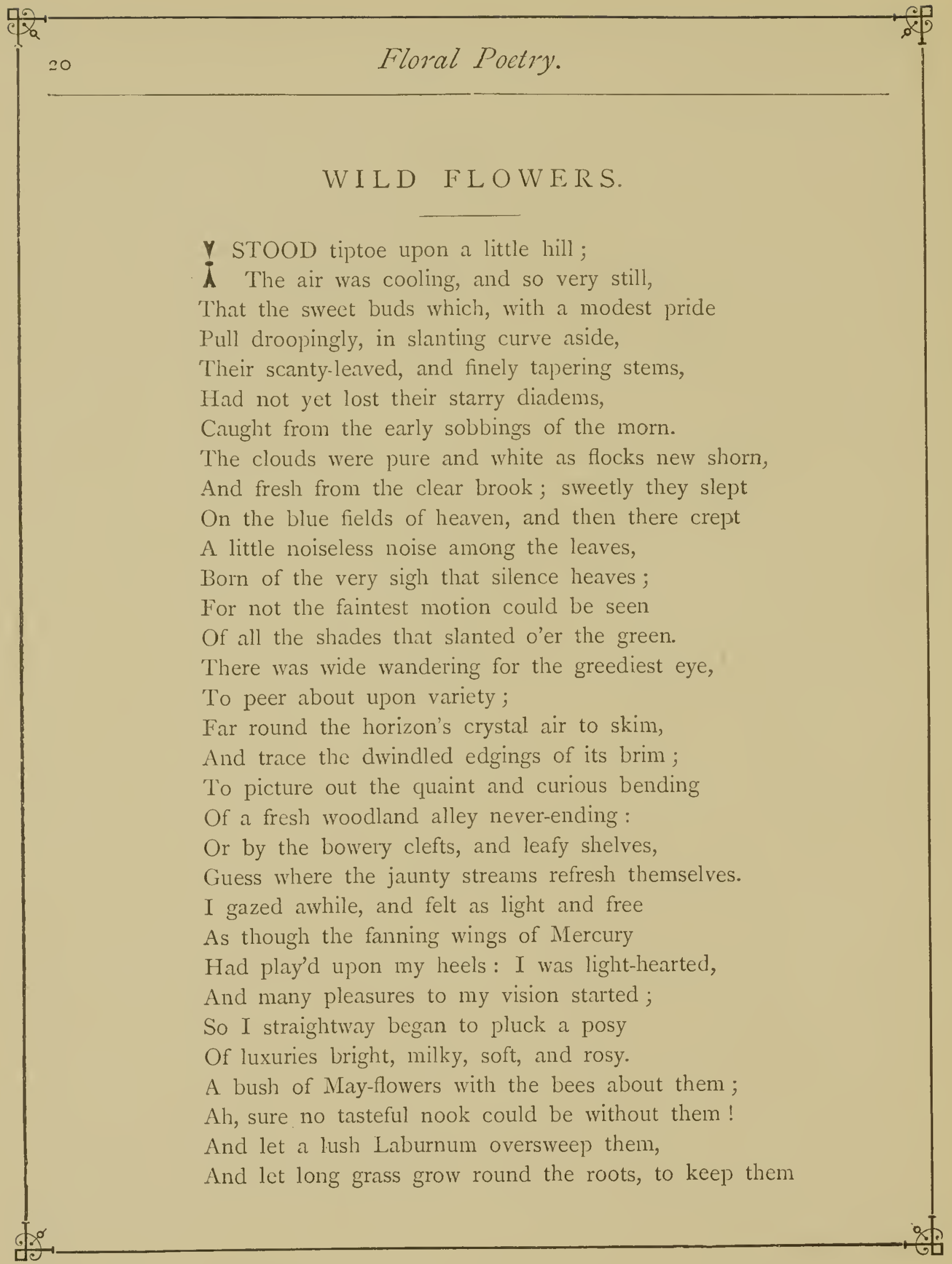




\section{Floral Poetry.}

Moist, cool, and green; and shade the Violets,

That they may bind the moss in leafy nets.

A Filbert hedge with Wildbrier overtwined, And clumps of Woodbine taking the soft wind Upon their Summer thrones; there, too, should be The frequent chequer of a youngling tree, That with a score of light green brethren shoots

From the quaint mossiness of aged roots:

Round which is heard a spring-head of clear waters,

Babbling so wildly of its lovely daughters, The spreading Bluebells : it may haply mourn

That such fair clusters should be rudely torn From their fresh beds, and scatter'd thoughtlessly

By infant hands, left on the path to die.

Open afresh your round of starry folds, Ye ardent Marigolds!

Dry up the moisture from your golden lids, For great Apollo bids

That in these days your praises should be sung On many harps, which he has lately strung; And when again your dewiness he kisses, Tell him, I have you in my world of blisses : So, haply when I rove in some far vale, His mighty voice may come upon the gale.

Here are Sweet Peas, on tiptoe for a flight: With wings of gentle flush o'er delicate white, And taper fingers catching at all things, To bind them all about with tiny rings. What next? a turf of evening Primroses, O'er which the mind may hover till it dozes;

O'er which it well might take a pleasant sleep, But that 'tis ever startled by the leap

Of buds into ripe flowers. 


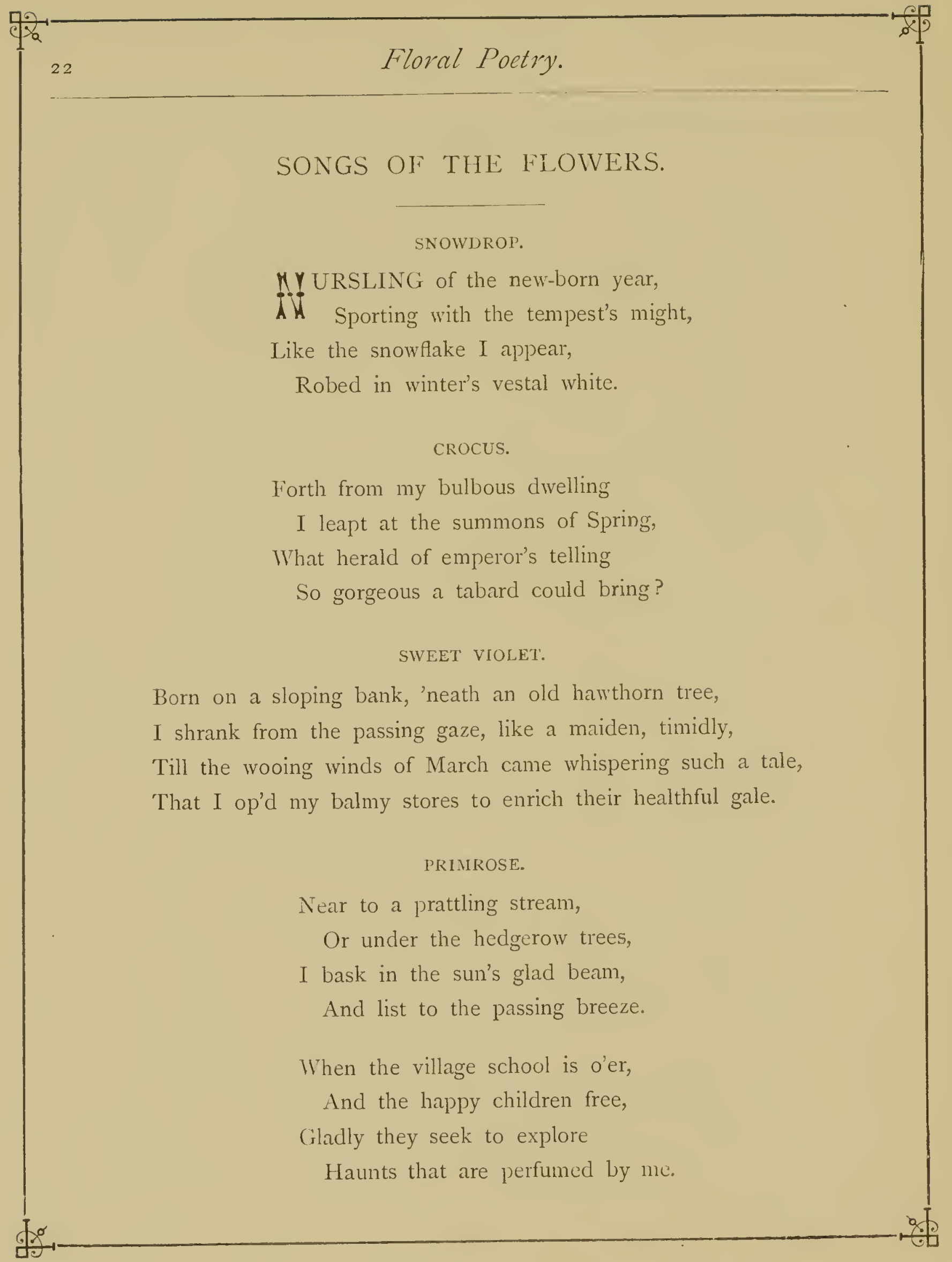


HEATH.

When the wild bee comes with a murmuring song,

Pilfering sweets as he roams along,

I uprear my purple bell :

Listening the freeborn eagle's cry,

Marking the heath-cock's glancing eye,

On the mountain side I dwell.

The echoes yet the notes prolong,

When one, who oft o'er hill and dell

Had sought the spots where flowerets dwell,

And knew their names and functions well,

And could of all their changes tell,

Thus answered to their song:

"Loveliest children of earth,

Of more than each rainbow hue,

Of beauty coëval with birth,

And fragrance found only in you!

"O ! that like you I could live, Free from all malice and strife,

That each thought and each pulse I could give

To the beautiful Giver of Life.

"Until earth shall wax old and decay,

You shall ever triumphantly shine,

And on leaf and on petal display

The work of an Artist Divine."

Robert Patterson. 


\section{A WILD FLOWER.}

OWN the shadowed lane she goes,
And her arms are laden

With the Woodbine and Wild Rose-

Happy little maiden!

Sweetly, sweetly doth she sing

As the lark above her:

Surely every living thing

That has seen must love her.

As she strayed and as she sung,

Happy little maiden!

Shadowy lanes and dells among,

With wild flowers laden,

Chanced a bonny youth that way,

For the lanes were shady:

She dropped one wee flower, they say,

Did this little lady.

Dropped a flower, so they say;

Dropped, and never missed it ;

And the youth, alack-a-day!

Picked it up and kissed it.

Now in sweet lane wanderings,

With love flowers laden,

With her love she strays and sings,

Happy little maiden!

Anon. 


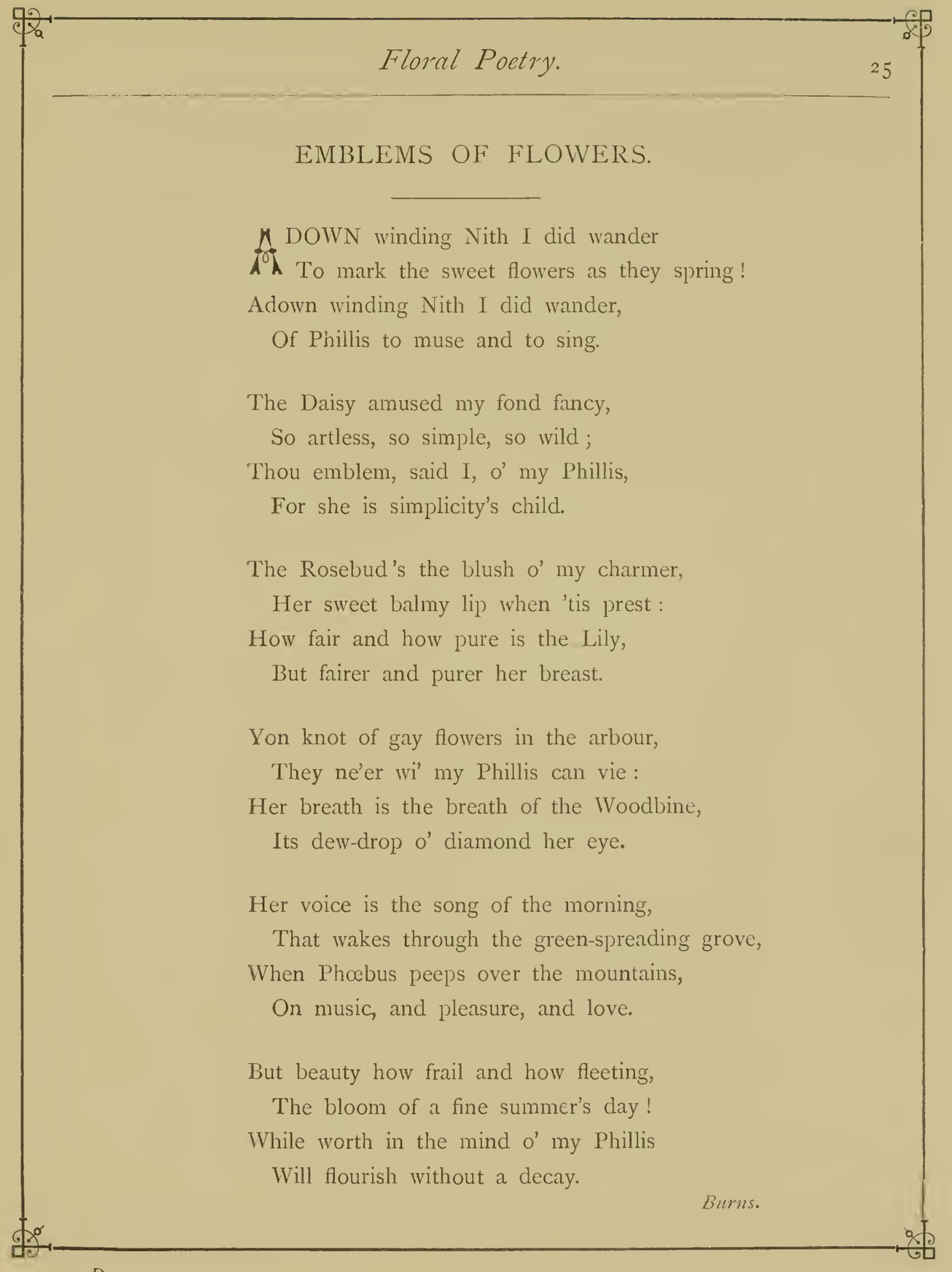




\section{WIL D FLOWERS.}

DREAMED that, as I wandered by the way,

A Bare Winter suddenly was changed to Spring,

And gentle odours led my steps astray,

Mixed with a sound of waters murmuring

Along a shelving bank of turf, which lay

Under a copse, and hardly dared to fling

Its green arms round the bosom of the stream,

But kissed it and then fled, as thou might'st in a dream.

There grew pied Wind-flowers and Violets,

Daisies, those pearled Arcturi of the earth,

The constellated flower that never sets;

Faint Oxlips; tender Bluebells, at whose birth

The sod scarce heaved; and that tall flower that wets

Its mother's face with heaven-collected tears,

When the low wind, its playmate's voice, it hears.

And in the warm hedge grew lush Eglantine,

Green Cowbind and the moonlight-coloured May,

And Cherry blossoms, and white cups, whose wine

Was the bright dew yet drained not by the day;

And IVild Roses, and Ivy serpentine,

With its dark buds and leaves, wandering astray,

And flowers azure, black, and streaked with gold,

Fairer than any wakened eyes behold.

And nearer to the river's trembling edge,

There grew broad Flag-flowers, purple prankt with white,

And starry River-buds among the sedge,

And floating Water Lilies, broad and bright, 
Which lit the oak that overhung the hedge

With moonlight beams of their orvn watery light;

And bulrushes and reeds of such deep green

As soothed the dazzled eye with sober sheen.

Methought that of these visionary flowers

I made a nosegay, bound in such a way

That the same hues which in their natural bowers

Were mingled or opposed, the like array

Kept these imprisoned children of the hours

Within my hand,- - and then, elate and gay,

I hastened to the spot whence I had come,

That I might there present it!-Oh! to whom?

\section{DECISION OF THE FLOWER.}

A ND with scarlet Poppies, around like a hower,

$\lambda \hat{\lambda}$ The maiden found her mystic flower.

"Now, gentle flower, I pray thee, tell

If my lover loves me, and loves me well:

So may the fall of the morning dew

Keep the sun from fading thy tender blue.

Now I number the leaves for my lot-

He loves not-he loves me-he loves me not-

He loves me-yes, thou last leaf, yes-

I'll pluck thee not for the last sweet guess!

He loves me!"- "Yes," a dear voice sighed,

And her lover stands by Margaret's side.

I. IE. Landon. 


\section{"GO TO THE FOREST SHADE."}

0 to the forest shade-

Seek thou the well-known glade,

Where, heavy with siveet dew, the Violets lie,

Gleaming through moss-tufts deep,

Like dark eyes filled with sleep,

And bathed in hues of summer's midnight sky.

Bring me their buds, to shed

Around my dying bed

A breath of May, and of the wood's repose;

For I in sooth depart

With a reluctant heart,

That fain would linger where the bright sun glows.

Fain would I stay with thee-

Alas! this may not be;

Yet bring me still the gifts of happier hours!

Go where the fountain's breast

Catches, in glassy rest,

The dim green light that pours through Laurel bowers.

I know how softly bright,

Steeped in that tender light,

The Water-lilies tremble there e'en now;

Go to the pure stream's edge,

And from its whispering sedge

Bring me those flowers to cool my fevered brow!

Then, as in Hope's young days,

Track thou the antique maze

Of the rich garden to its grassy mound;

There is a lone White Rose,

Shedding, in sudden snows,

Its faint leaves o'er the emerald turf around. 
Well know'st thou that fair tree-

A murmur of the bee

Dwells ever in the honied lime above;

Bring me one pearly flower

Of all its clustering shower-

For on that spot we first revealed our love.

Gather one Woodbine bough,

Then, from the lattice low

Of the bowered cottage which I bade thee mark,

When by the hamlet last,

Through dim wood-lanes we passed,

While dews were glancing to the glow-worm's spark.

Haste! to my pillow bear

Those fragrant things and fair,

Thy hand no more may bind them up at eve-

Yet shall their odour soft

One bright dream round me waft

Of life, youth, summer-all that I must leave!

And, oh! if thou would'st ask

Wherefore thy steps I task,

The grove, the stream, the hamlet vale to trace,

'Tis that some thought of me,

When I am gone, may be

The spirit bound to each familiar place.

I bid mine image dwell

(Oh! break not thou the spell)

In the deep wood and by the fountain side;

Thou must not, my beloved!

Rove where we two have roved,

Forgetting her that in her spring-time died !

Mis. Henlans. 


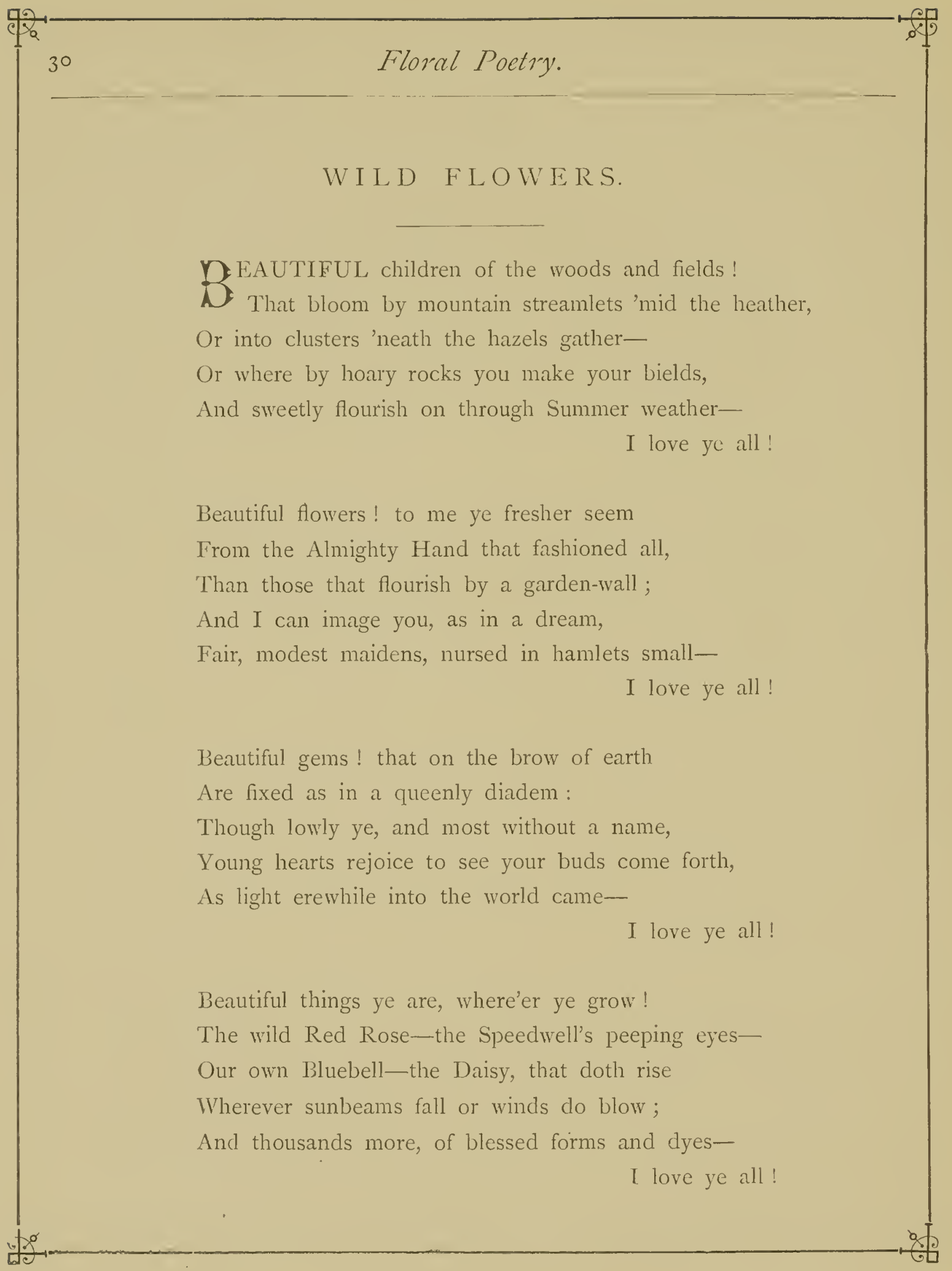




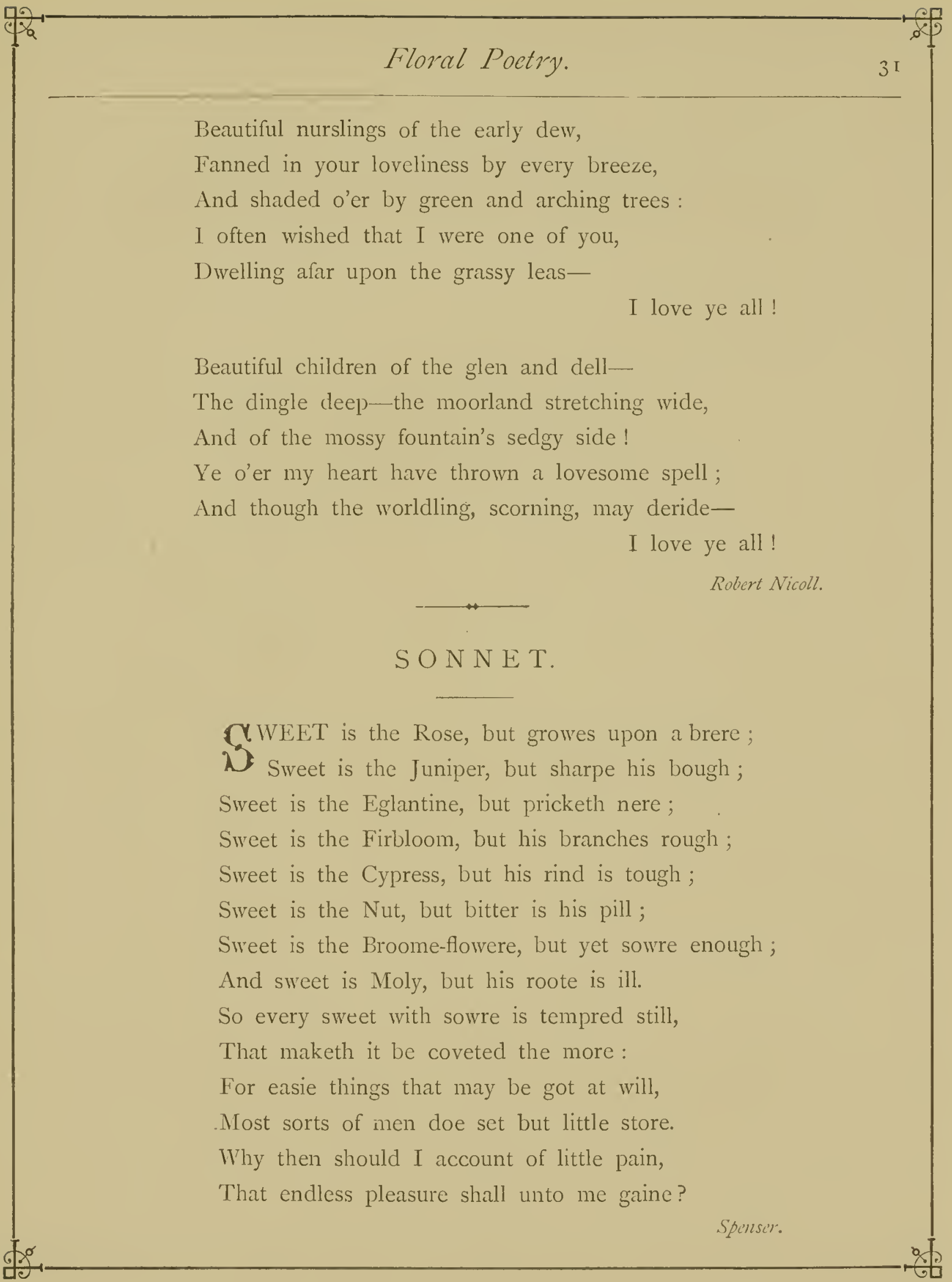




\section{CHILDREN OF THE SUN'S FIRST GLANCING.}

CHILDREN of the sun's first glancing,

$\bigcup$ Flowers that deck the bounteous earth;

Joy and mirth are round ye dancing,

Nature smiled upon your birth;

Light hath veined your petals tender, And with hues of matchless splendour

Flora paints each dewy bell;

But lament, ye sweet spring blossoms, Soul hath never thrilled your bosoms,

All in cheerless night ye dwell.

Nightingale and lark are singing

Many a lay of love to you;

In your chaliced blossoms swinging,

Tiny sylphs their sylphids woo;

Deep within the painted bower

Of a soft and perfumed flower,

Venus once did fall asleep;

But no pulse of passion darted

Through your breast, by her imparted-

Children of the morning, weep.

When my mother's harsh rejection

Bids me cease my love to speak-

Pledges of a true affection,

When your gentle aid I seek-

Then by every voiceless token

Hope, and faith unchanged, are spoken,

And by you my bosom grieves;

Love himself among you stealeth,

And his awful form concealeth,

Shut within your folding leaves.

From Schiller. 


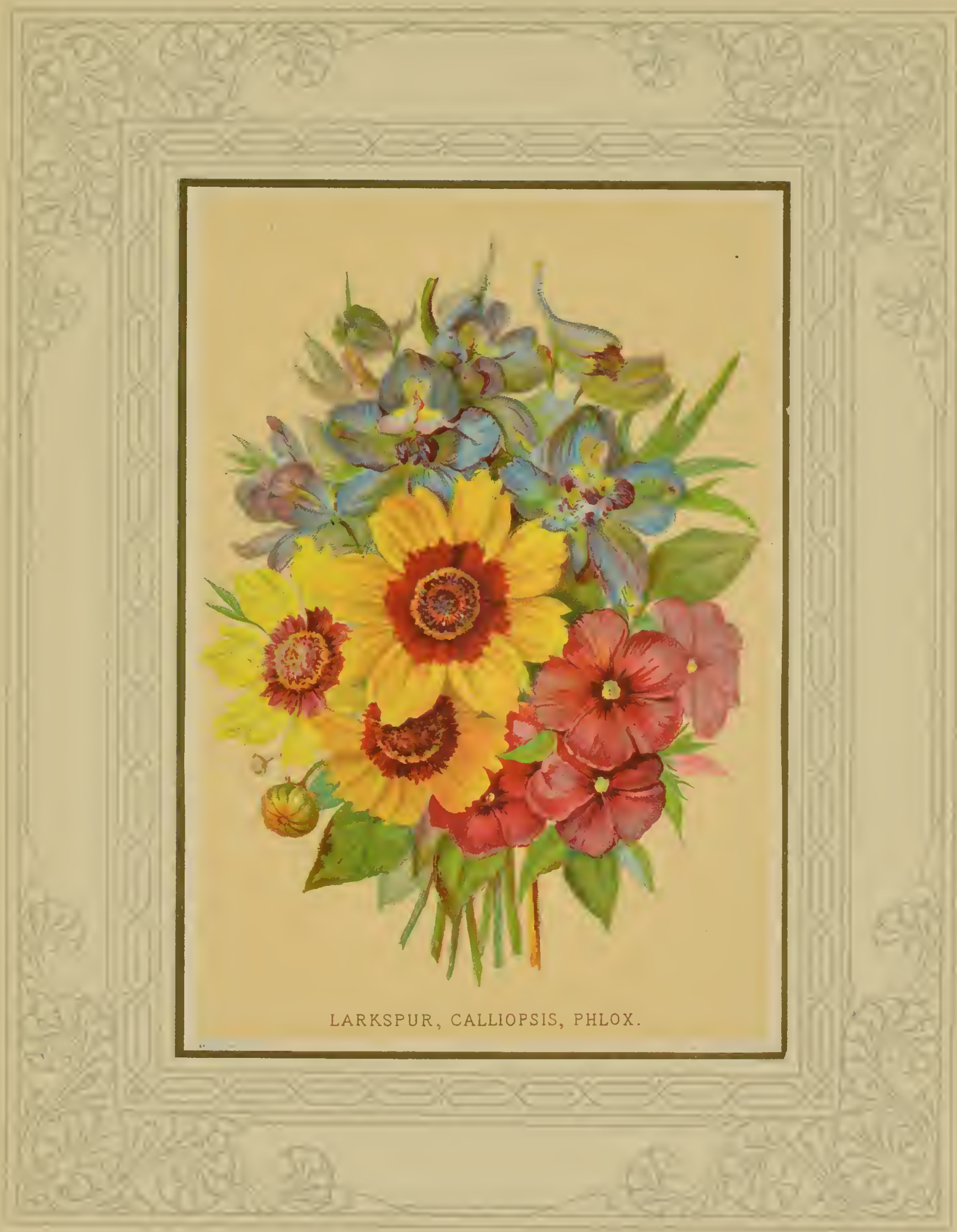




\section{THE FLOWER-D I A L.}

'MrWWAS a lovely thought to mark the hours,

$\boldsymbol{\lambda}$ As they floated in light away,

By the opening and the folding flowers,

That laugh to the Summer's day.

Thus had each moment its own rich hue,

And its graceful cup and bell,

In whose coloured vase might sleep the dew,

Like a pearl in an ocean shell.

To such sweet signs might the time have flowed

In a golden current on,

Ere from the garden, man's first abode,

The glorious guests were gone.

So might the days have been brightly told-

Those days of song and dreams-

When shepherds gathered their flocks of old,

By the blue Arcadian streams.

So in those isles of delight, that rest

Far off in a breezeless main,

Which many a bark, with a weary quest,

Has sought, but still in vain.

Yet is not life, in its real flight,

Marked thus-even thus-on earth,

By the closing of one hope's delight,

And another's gentle birth?

Oh ! let us live, so that flower by flower.

Shutting in turn, may leave

A lingerer still for the sunset hour,

A charm for the shaded eve.

Mrs. Hemans. 


\section{Floral Poetry.}

\section{THE WREATH.}

TO A FRIEND ON HER BIRTHDAY.

ET others sing the rich, the great,

if The victor's palm, the monarch's state,

A purer joy be mine--

To greet the excellent of earth,

To call down blessings on thy worth,

And, for the hour that gave thee birth,

- Life's choicest flowers entwine.

And 10 ! where smiling from above

(Meet helpmate in the work of love)

O'er opening hill and lawn,

With flowerets of a thousand dyes,

With all that's sweet of earth and skies,

Soft breathes the vernal dawn.

Come! from her stores we'll cull the best

Thy bosom to adorn;

Each leaf in livelier verdure drest,

Each blossom balmier than the rest,

Each rose without a thorn;

Fleet tints, that with the rainbow died,

Brief flowers, that withered in their pride,

Shall, blushing into light, awake

And kindlier bloom, for thy dear sake.

And first-though oft, alas! condemned

Like merit, to the shade-

The Primrose meek, with dews begemmed,

Shall sparkle in the braid; 
The Daisy, so contently gay,

Opening her eyelids with the day;

The Gorse-bloom, never sad or sere,

But golden bright,

As gems of night,

And fresh and fragrant all the year;

Each leaf, each bud of classic lore,

Oak, Hyacinth, and Floramore;

The Cowslip, graceful in her woe;

The Hawthorn's smile, the Poppy's glow,

This ripe with balm for present sorrow,

And that with raptures for to-morrow.

The flowers are culled; and each lithe stem

With Woodbine band we braid-

With Woodbine, type of Life's best gem,

Of truth that will not fade.

The wreath is wove; do Thou, blest Power,

That brood'st o'er leaflet, fruit, and flower,

Embalm it with Thy love;

Oh! make it such as angels wear,

Pure, bright, as decked earth's first-born pair,

Whilst free in Eden's grove,

From herb and plant they brushed the dew,

And neither sin nor sorrow knew.

Willian Peters.

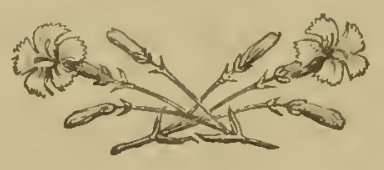




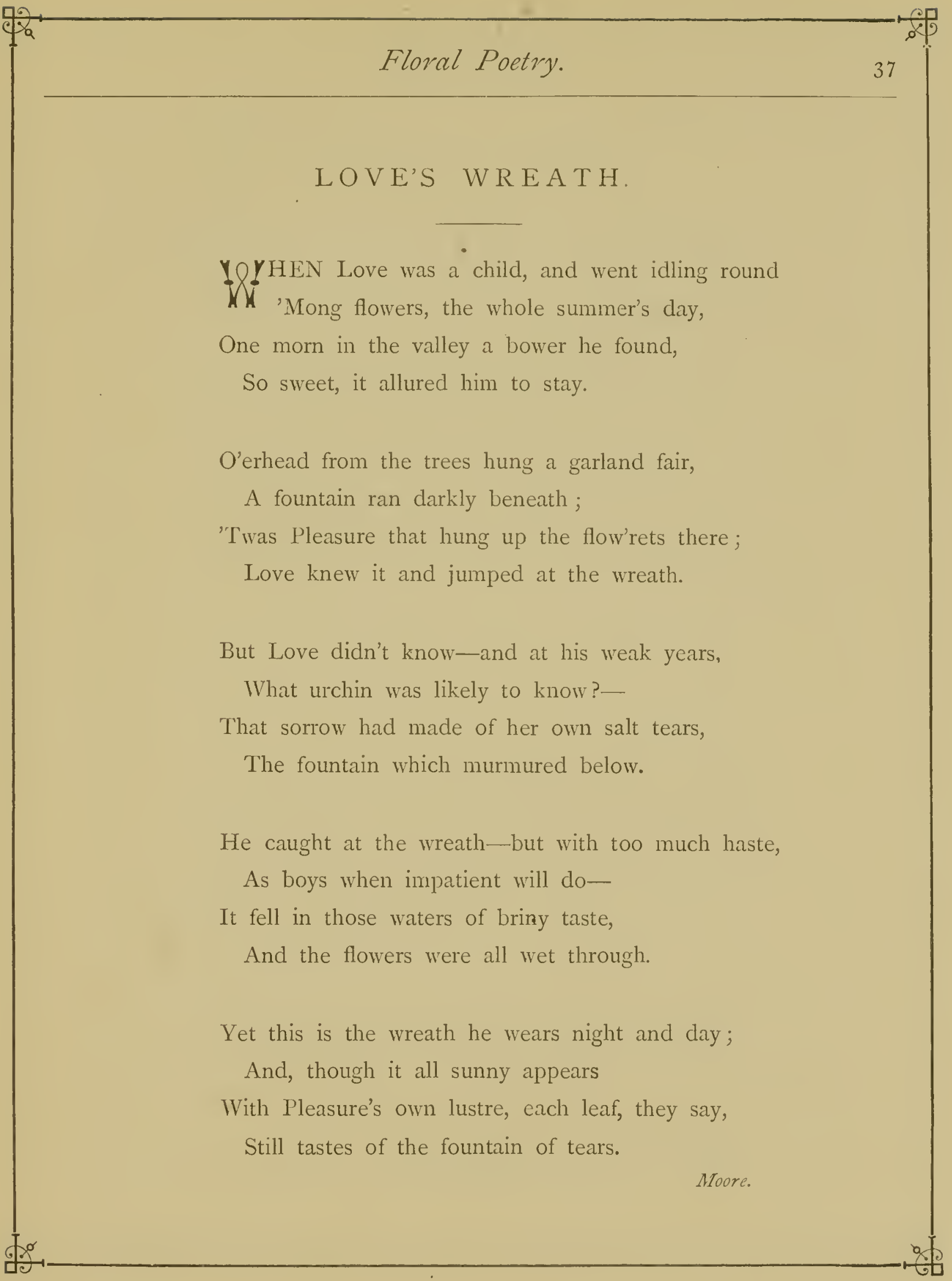




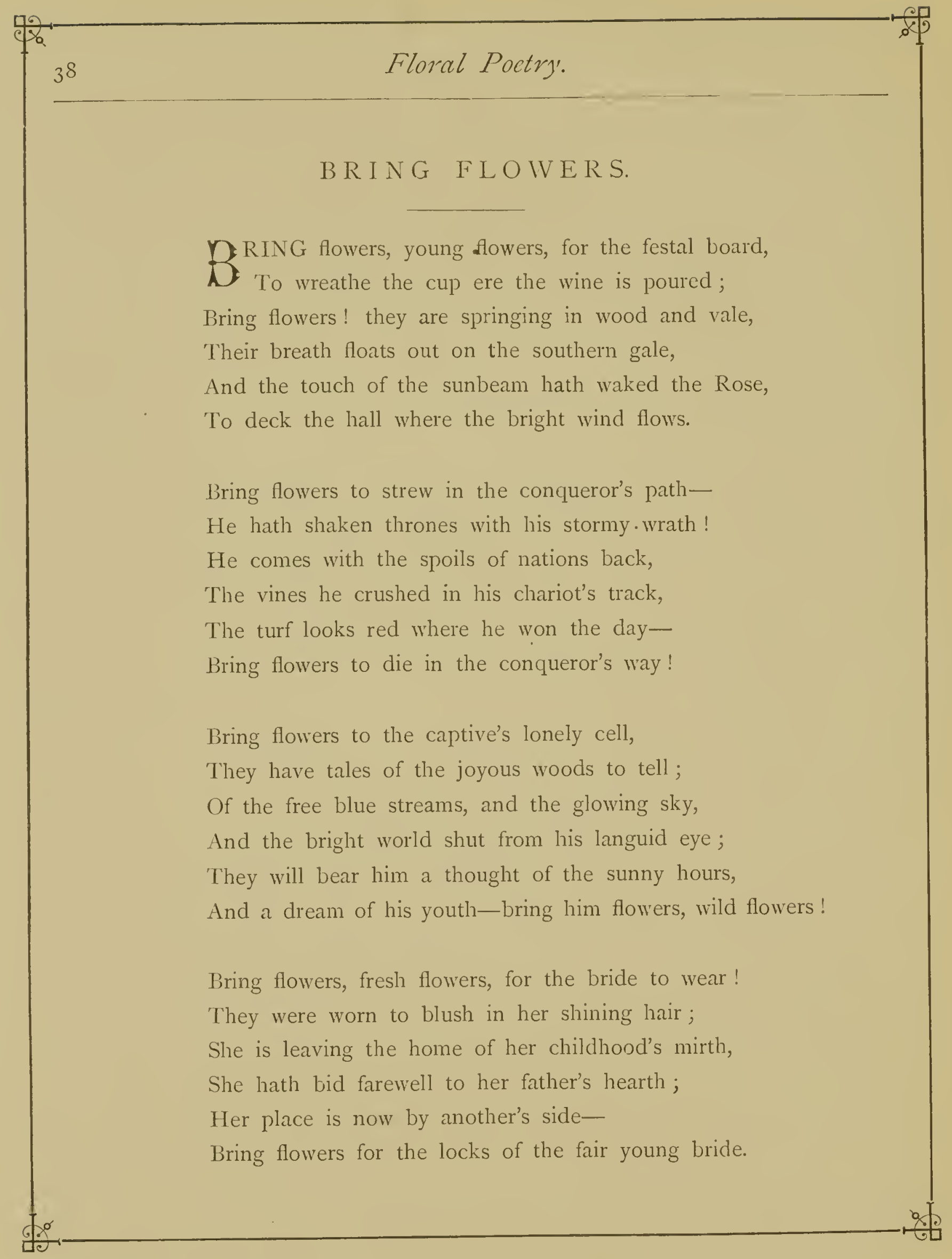




\section{Floral Poetry.}

Bring flowers, pale flowers, o'er the bier to shed,

A crown for the brow of the early dead!

For this through its leaves hath the IVild Rose burst,

For this in the woods was the Violet nursed!

Though they smile in vain for what once was ours,

They are Love's last gift-bring ye flowers, pale flowers!

Bring flowers to the shrine where we kneel in prayer,

They are Nature's offering, their place is there!

They speak of hope to the fainting heart,

With a voice of promise they come and part,

They sleep in dust in the wintry hours,

They break forth in glory-bring flowers, bright flowers!

Mrs. ITemans.

\section{F R A G M E N T.}

GOME clothe the soil that feeds them, far diffused

2. And lowly creeping, modest and yet fair,

Iike Virtue, thriving most where little seen;

Some, more aspiring, catch the neighlour shrub

With clasping tendrils, and invest his branch,

Else unadorned, with many a gay festoon

And fragrant chaplet, recompensing well

The strength they borrow with the grace they lend.

Cowper. 


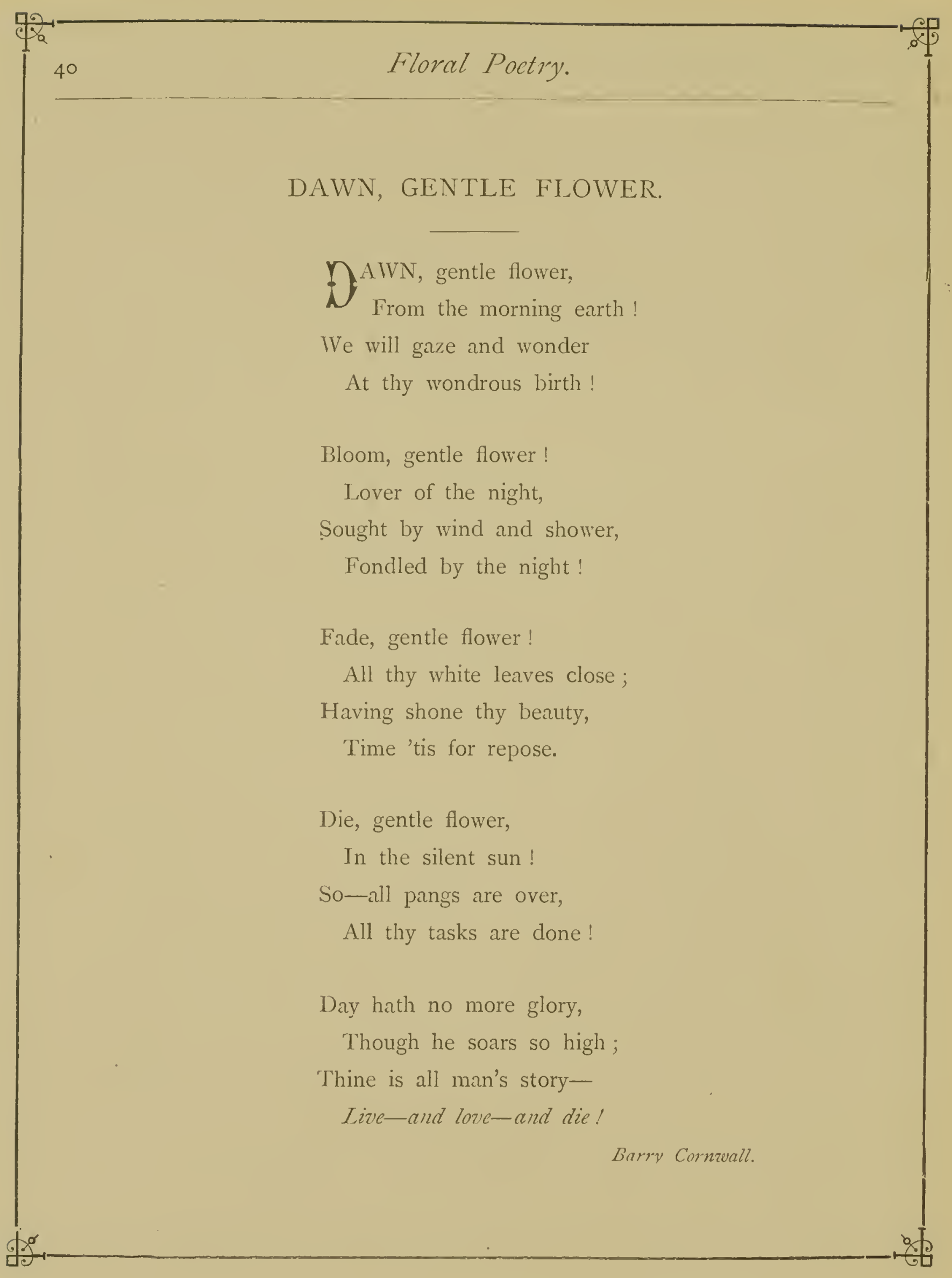




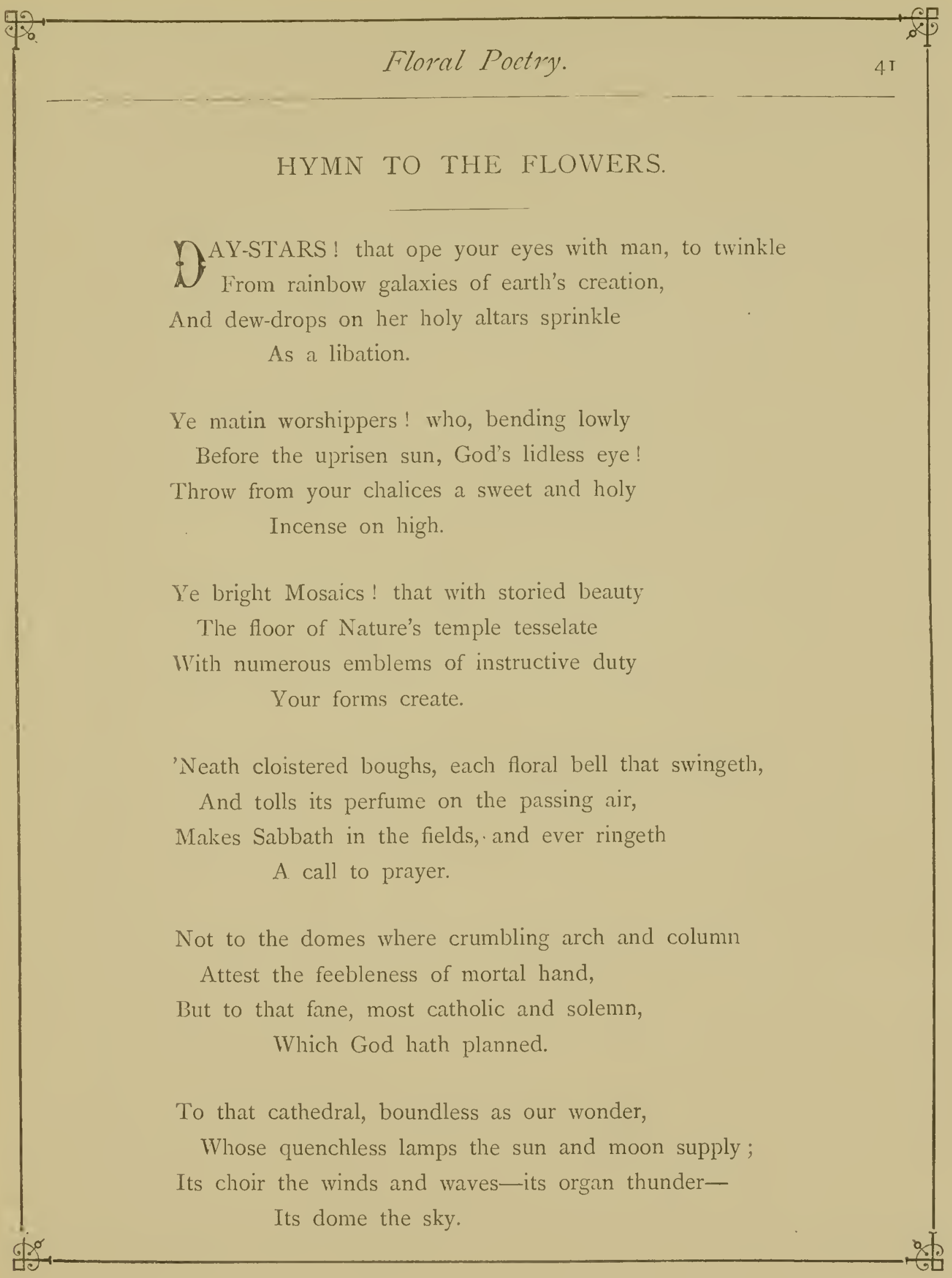




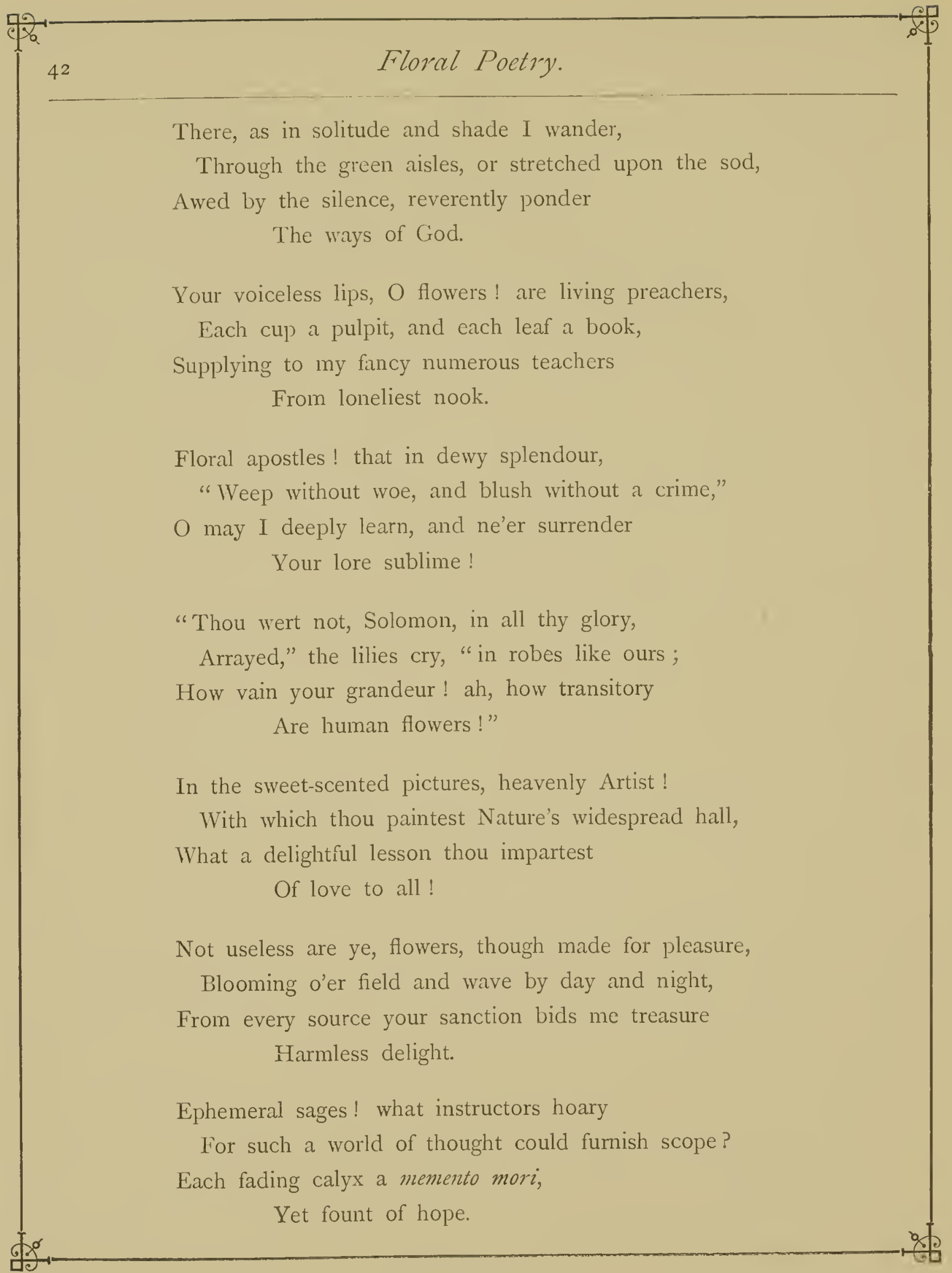


Posthumous glories! angel-like collection !

Upraised from seed or bulb interred in earth,

$\mathrm{Ye}$ are to me a type of resurrection,

A second birth.

Were I, O God, in churchless lands remaining,

Far from all voice of teachers or divines,

My soul would find, in flowers of thy ordaining,

Priests, sermons, shrines !

Horace Smith.

THE SHEPHERD TO THE FLOWERS.

TWEET Violets, Love's paradise, that spread

2. Your gracious odours, which you, couchéd, bear

Within your paly faces,

Upon the gentle wing of some calm-breathing wind,

That plays amidst the plain!

If, by the favour of propitious stars, you gain

Such grace as in my lady's bosom place to find,

Be proud to touch those places:

And when her warmth your moisture forth doth wear,

Whereby her dainty parts are sweetly fed,

You, honours of the flowery meads, I pray,

You pretty daughters of the earth and sun,

With mild and seemly breathing straight display

My bitter sighs, that have my heart undone!

Sir Walter Raleigh. 


\section{BLESSED BE GOD FOR FLOWERS.}

$B^{\prime}$

LESSED be God for flowers;

For the bright, gentle, holy thoughts that breathe

From out their odorous beauty, like a wreath

Of sunshine on life's hours.

Ay, prize them well, my child-

The bright young blooming things that never die-

Pointing our hopes to happier worlds that lie

Far o'er this earthly wild;

Prize them, that when forgot

By all, their old familiar tints shall bring

Sweet thoughts of her, whose dirge the deep winds sing,

And whose love earth holds not;

Prize them, that through all hours

Thou hold'st sweet commune with their beauty here;

And, rich in this, through many a future year,

Bless thou our God for flowers !

Mrs. Tinsley.

\section{THE BROKEN FLOWER.}

$\{\mathrm{H}$ ! wear it on thy heart, my love,

Sweetness is lingering in its leaves,

Though faded be their smile.

Yet for the sake of what hath been,

Oh! cast it not away; .

'Twas born to grace a summer scene,

A long, bright, golden day,

My love,

A long, bright, golden day! 


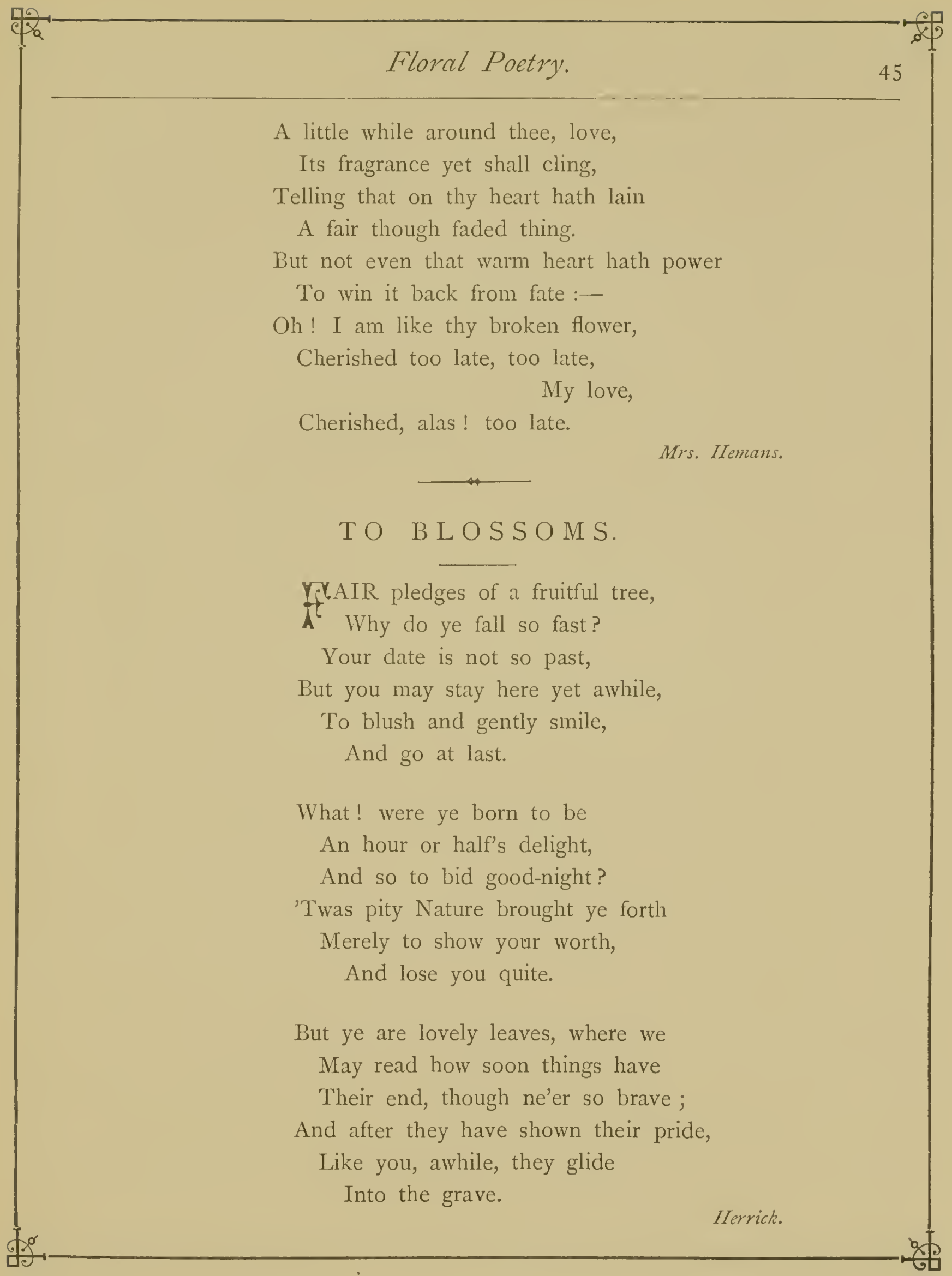




\section{F A D E D F L W E R S.}

T.ADED flowers,

$\boldsymbol{A}^{t}$ Sweet faded flowers,

Beauty and death

Have ruled your hours,

Ye woke in bloom but a morn ago,

And now are your blossoms in dust laid low.

But yesterday,

With the breeze ye strove-

In the play of life,

In the pride of love;

To and fro swung each radiant head,

That now is drooping, and pale, and dead!

Delicate flower,

With the pearl-white bells,

No more shall dew-drop

Sleep in thy cells!

No more, rich Rose, on thy heaving breast,

The honey-bee fold his wings to rest!

Fair myrtle tree,

Thy blossoms lie low,

But green above them

The branches grow;

Like a buried love, or a vanished joy,

Linked unto memories none destroy. 
Faded flowers,

Sweet faded flowers !-

Fair frail records

Of Eden's bowers ;

In a world where sorrow and wrong bear sway,

Why should ye linger?-Away! away!

What were the emblems

Pride to stain,

Might ye your glorious

Crowns retain?

And what for the young heart, bowed with grief,

Were the Rose ne'er seen with a withered leaf!

Ye bloom to tell us

What once hath. been;

What yet shall in heaven

Again be seen;

Ye die, that man in his strength may learn

How vain the hopes in his heart that burn.

Many in form,

And bright in hue!

I know your fate-

But the earth to strew-

And my soul flies on to immortal bowers, Where the heart and the Rose are not faded flowers.

Miss ferwsbury. 


\section{TRANSPLANTED FLOWERS.}

YE living gems of cold and fragrant fire!

$\boldsymbol{A}$ Die ye for ever, when ye die, ye flowers?

Take ye, when in your beauty ye expire,

An everlasting farewell of your bowers?

No more to listen for the wooing air,

And song-brought morn, the cloud-tinged woodlands

o'er!

No more to June's soft lip your breasts to bare,

And drink fond evening's dewy breath no more!

Soon fades the sweetest, first the fairest dies,

For frail and fair are sisters; but the heart,

Filled with deep love, Death's power to kill denies,

And sobs e'en o'er the dead, "We cannot part!"

Have I not seen thee, Wild Rose, in my dreams?

Like a pure spirit-beauteous as the skies,

When the clear blue is brightest, and the streams

Dance down the hills, reflecting the rich dyes

Of morning clouds, and cistus woodbine-twined-

Didst thou not wake me from a dream of death?

Yea, and thy voice was sweeter than the wind

When it inhales the love-sick Violet's breath,

Bending it down with kisses, where the bee

Hums over golden gorse, and sunny broom.

Soul of the Rose! what said'st thou then to me?

"We meet," thou said'st, "though severed by the tomb:

Lo, brother, this is heav'n! and thus the just shall

bloom."

E. Elliott. 


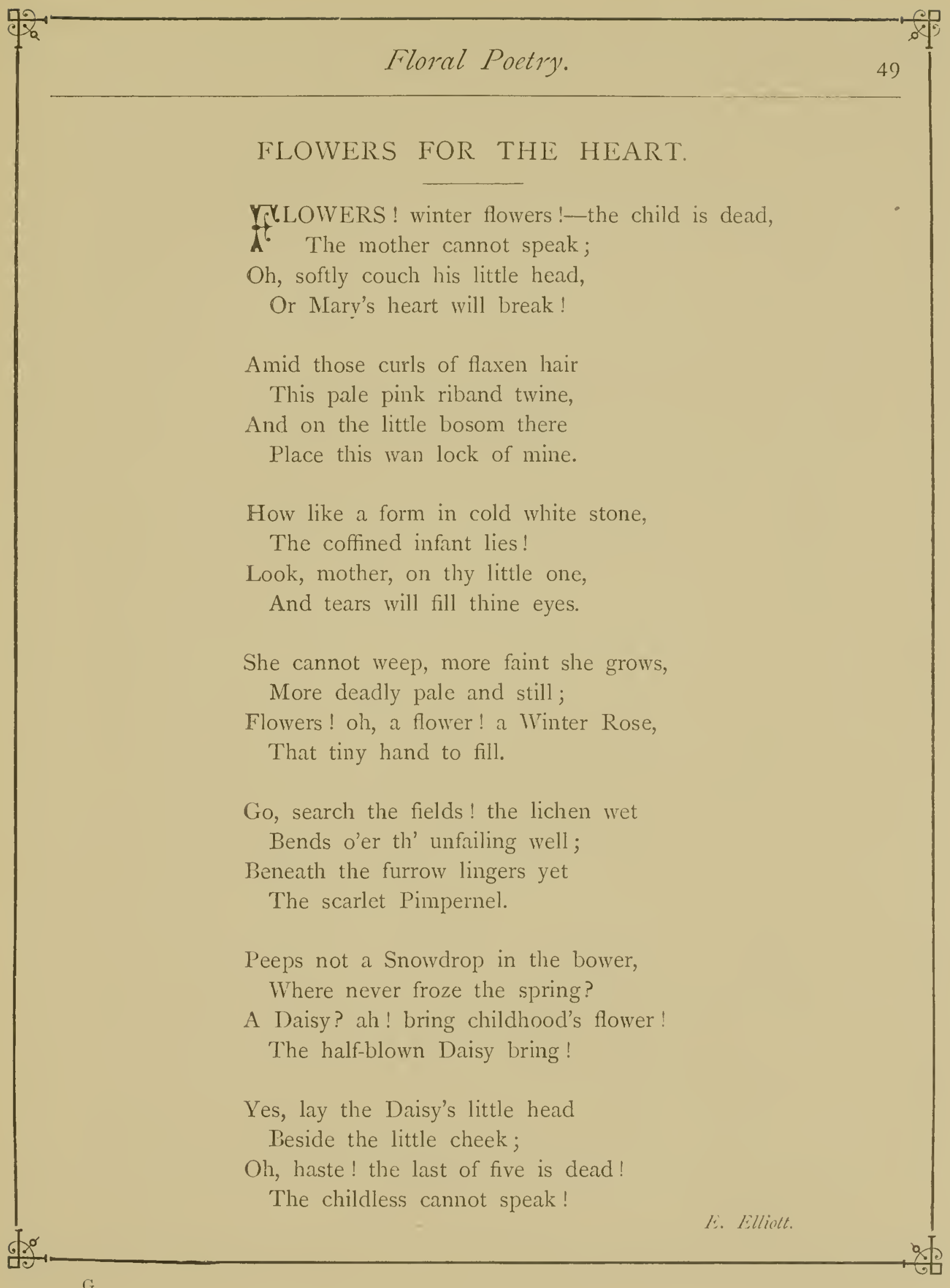




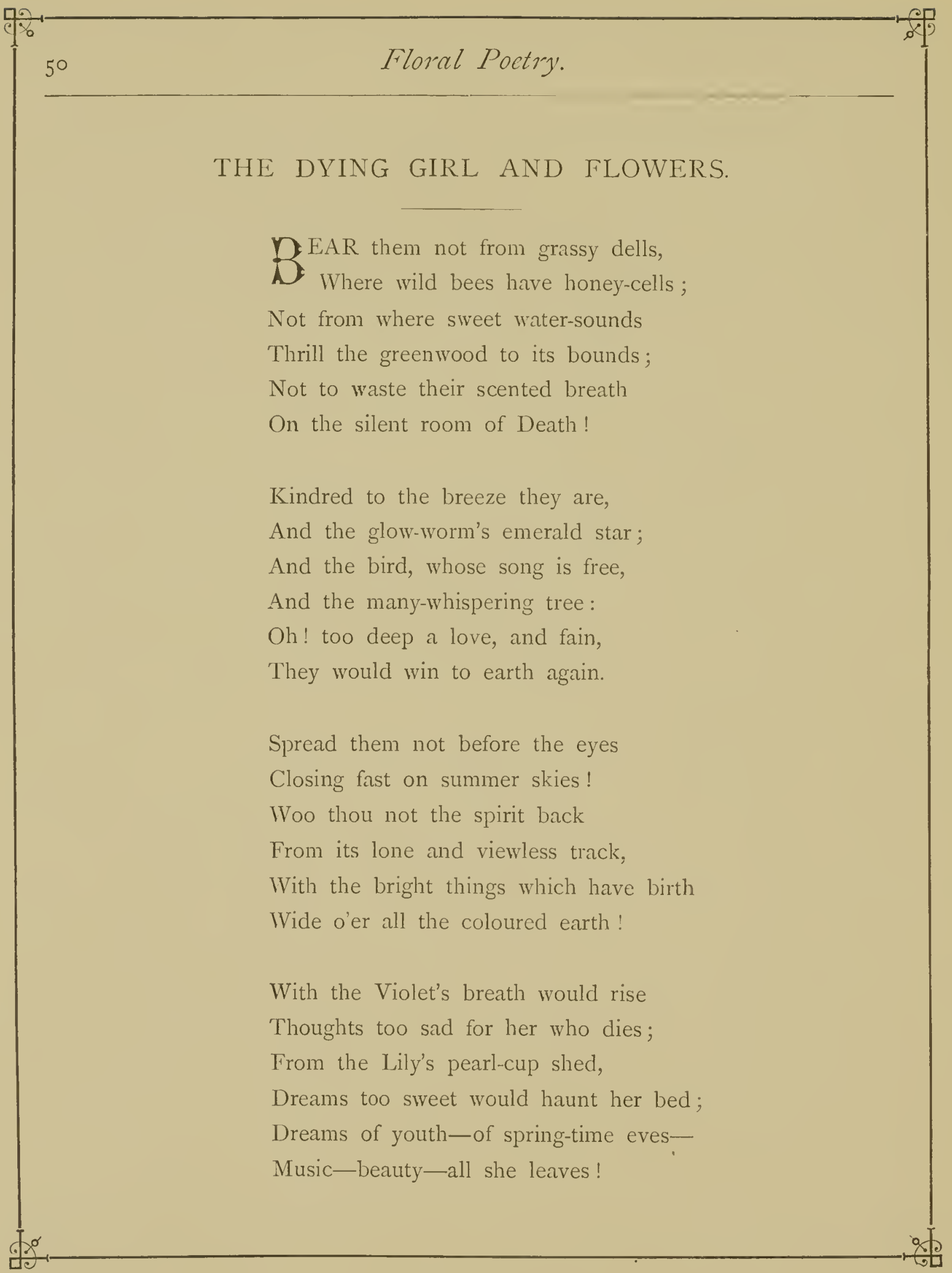




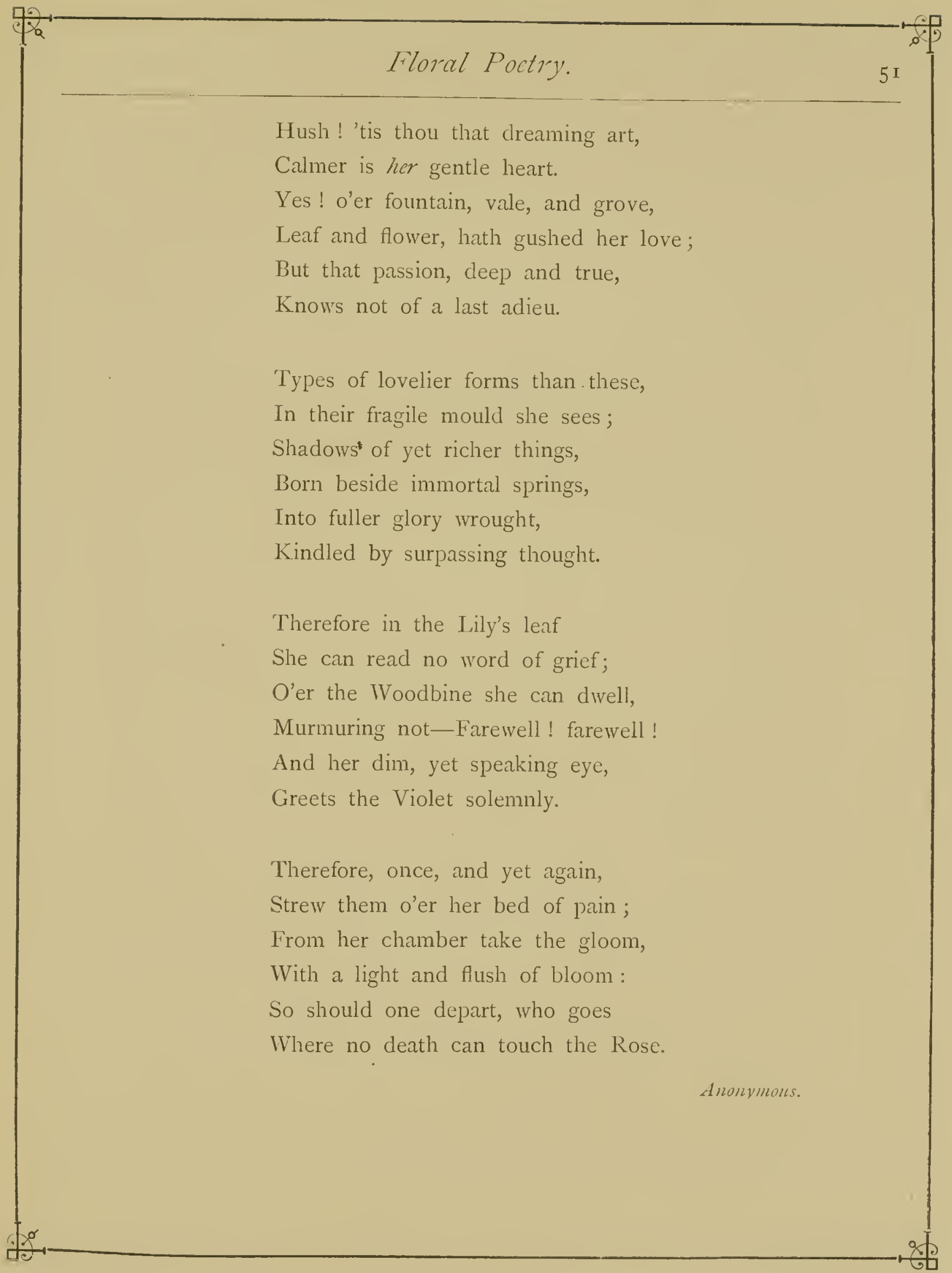


Y LOVED you ever, gentle flowers,

$\dot{\boldsymbol{i}}$ And made you playmates of my youth;

The while your spirit stole

In secret to my soul,

To shed a softness through my ripening powers,

And lead the thoughtful mind to deepest truth.

And now, when weariness and pain

Had cast you almost from my breast,

With each a smiling face,

In all your simple grace,

You come once more to take me back again

From pain to ease, from weariness to rest.

Kind visitants! through my sick-room

You seem to breathe an air of health,

And with you looks of joy

To wake again the boy,

And to the pallid cheek restore its bloom,

And o'er the desert mind pour boundless wealth.

And whence ye came, by brimming stream,

'Neath rustling leaves, with birds within,

Again I. musing tread-

Forgot my restless bed,

And long sick hours-Too short the blessed dream!

I woke to pain! - to hear the city's din! 


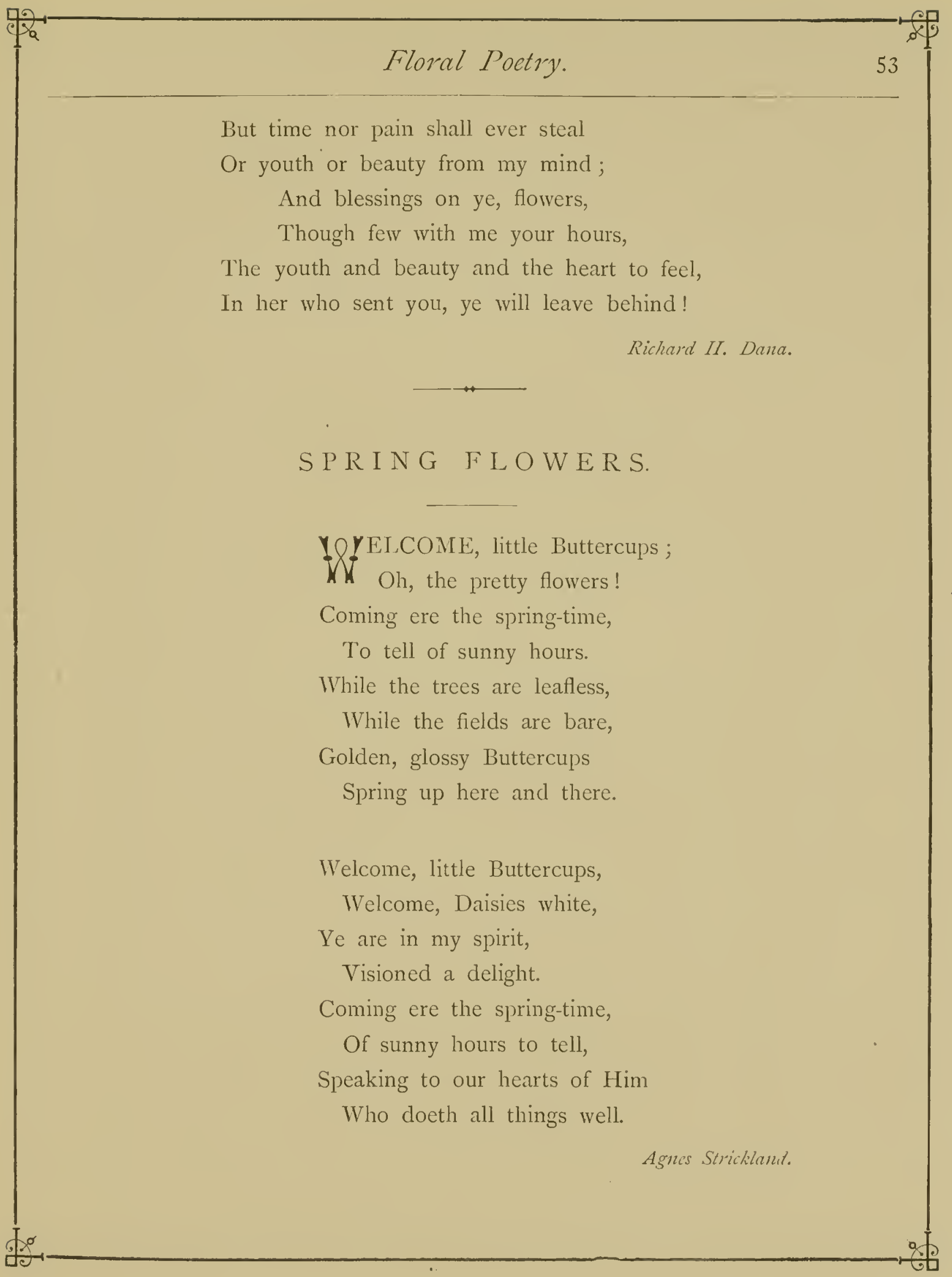




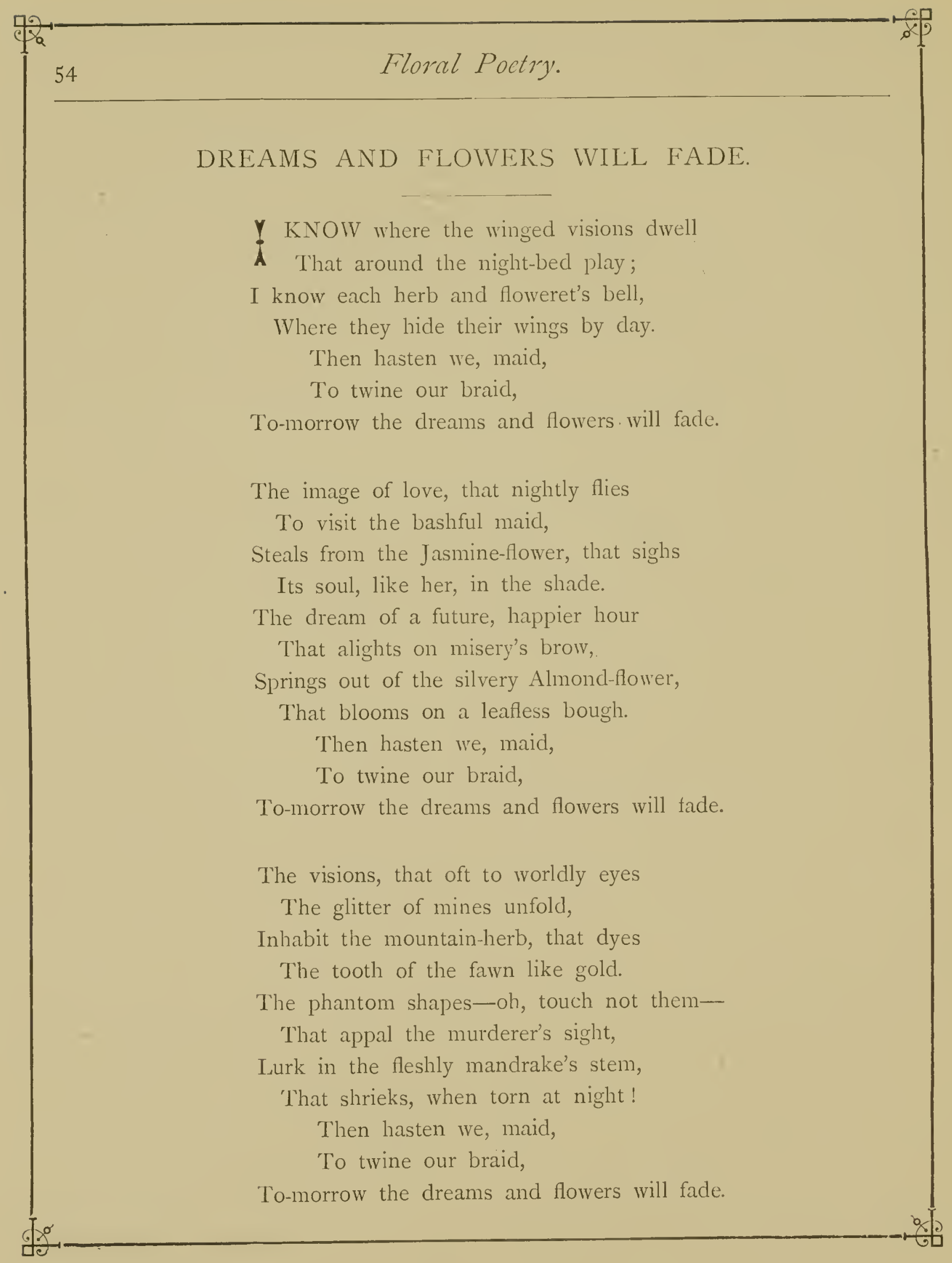




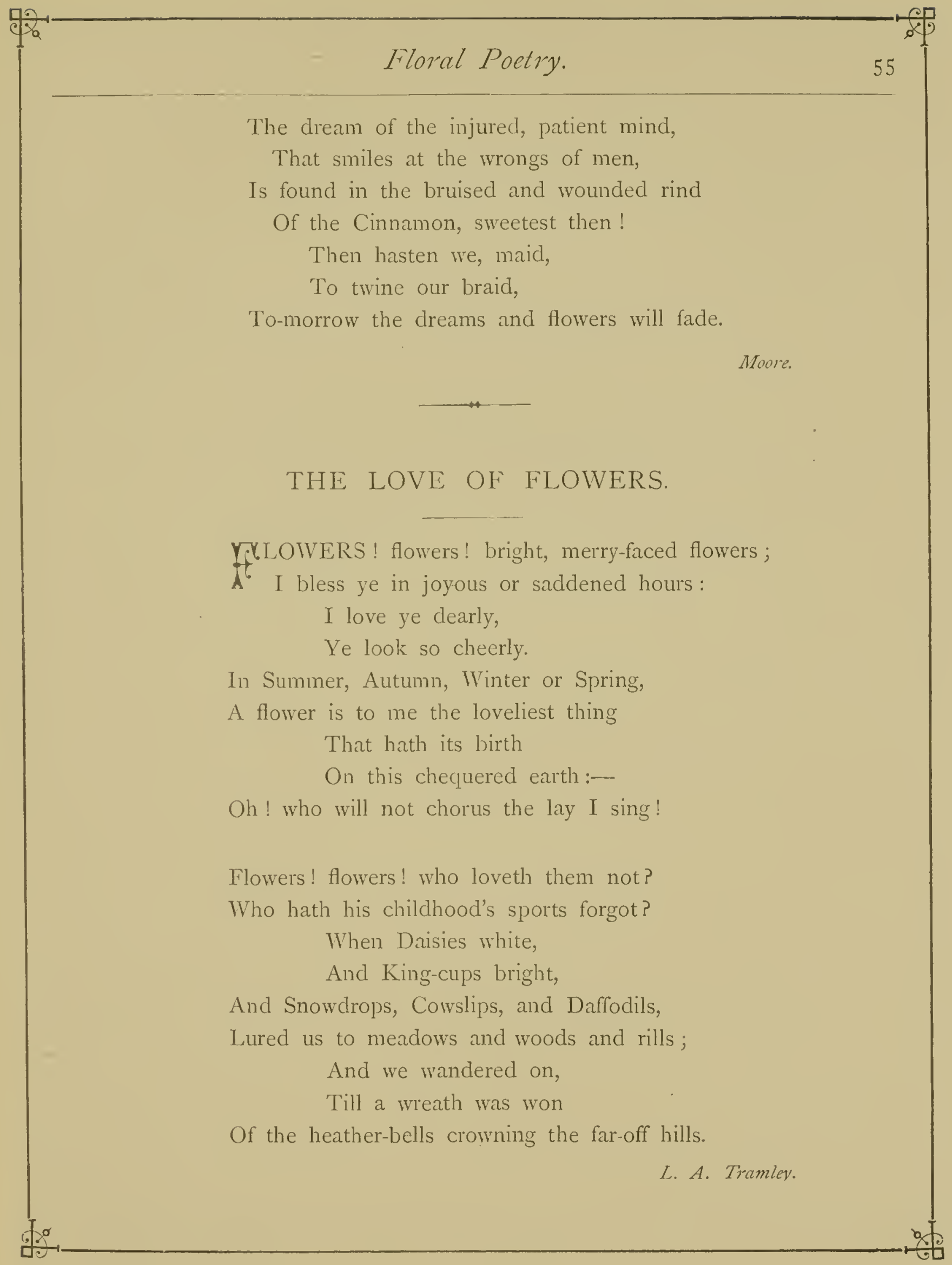




\section{Floral Poetry.}

\section{THE G A R L A N D.}

yr.HE pride of every grove I chose,

$\boldsymbol{A}$ The Violet sweet, the Lily fair,

The dappled Pink and blushing Rose,

To deck my charming Chloe's hair.

At morn the nymph vouchsafed to place

Upon her brow the various wreath;

The flowers less blooming than her face,

The scent less fragrant than her breath.

The flowers she wore along the day,

And every nymph and shepherd said,

That in her hair they looked more gay

Than glowing in their native bed.

Undressed at evening, when she found

Their odours lost, their colours past;

She changed her look, and on the ground

Her garland and her eyes she cast.

That eye dropped sense distinct and clear,

As any Muse's tongue could speak,

When from its lid a pearly tear

Ran trickling down her beauteous cheek.

Dissembling what I knew too well,

My love, my life, said I, explain

This change of humour: pr'ythee tell:

That falling tear-what does it mean? 


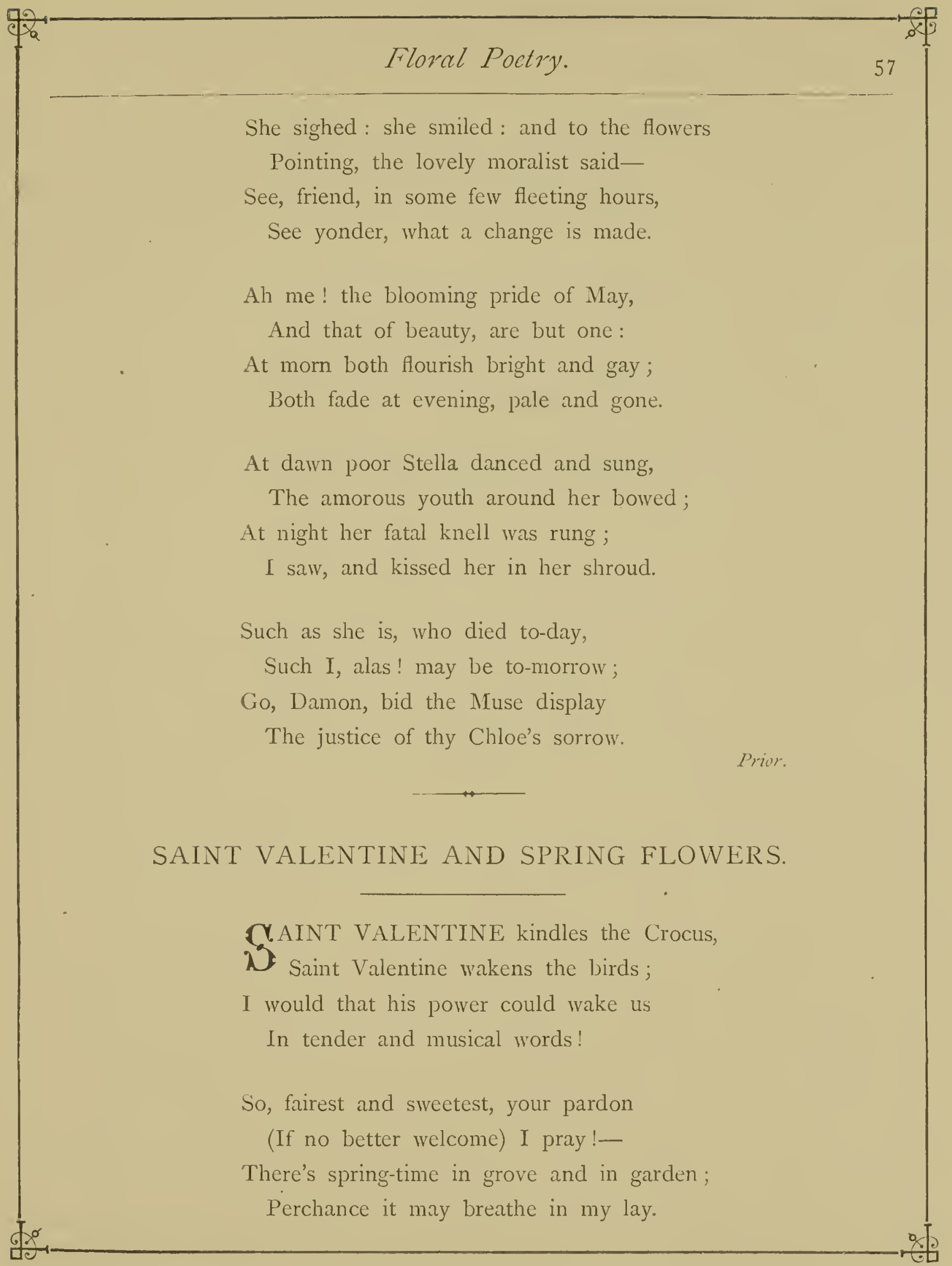


$I$ think and I dream (did you know it?)

Of somebody's eyes, her soft hair,

The neck bending whitely below it,

The dress that she chances to wear.

Each tone of her voice I remember,

Each turn of her head, of her arm;

Methinks, had she faults out of number,

Being hers, they were certain to charm.

So friendly her face that I tremble,

On friendship so sweet having ruth;

But why should I longer dissemble?

Or will you not guess at the truth?

And that is, dear maiden, I love you !

The sweetest, the brightest, the best!

Happy the roof-tree above you,

The floor where your footstep is prest?

May some new deliciousness meet you

On every new day of the Spring;

Each flower, in its turn, bloom to greet you,

Lark, mavis, and nightingale sing.

May kind vernal powers in your bosom

Their tenderest influence shed!

May I, when the Rose is in blossom,

Enweave you a crown, white and red.

W. Allingham. 


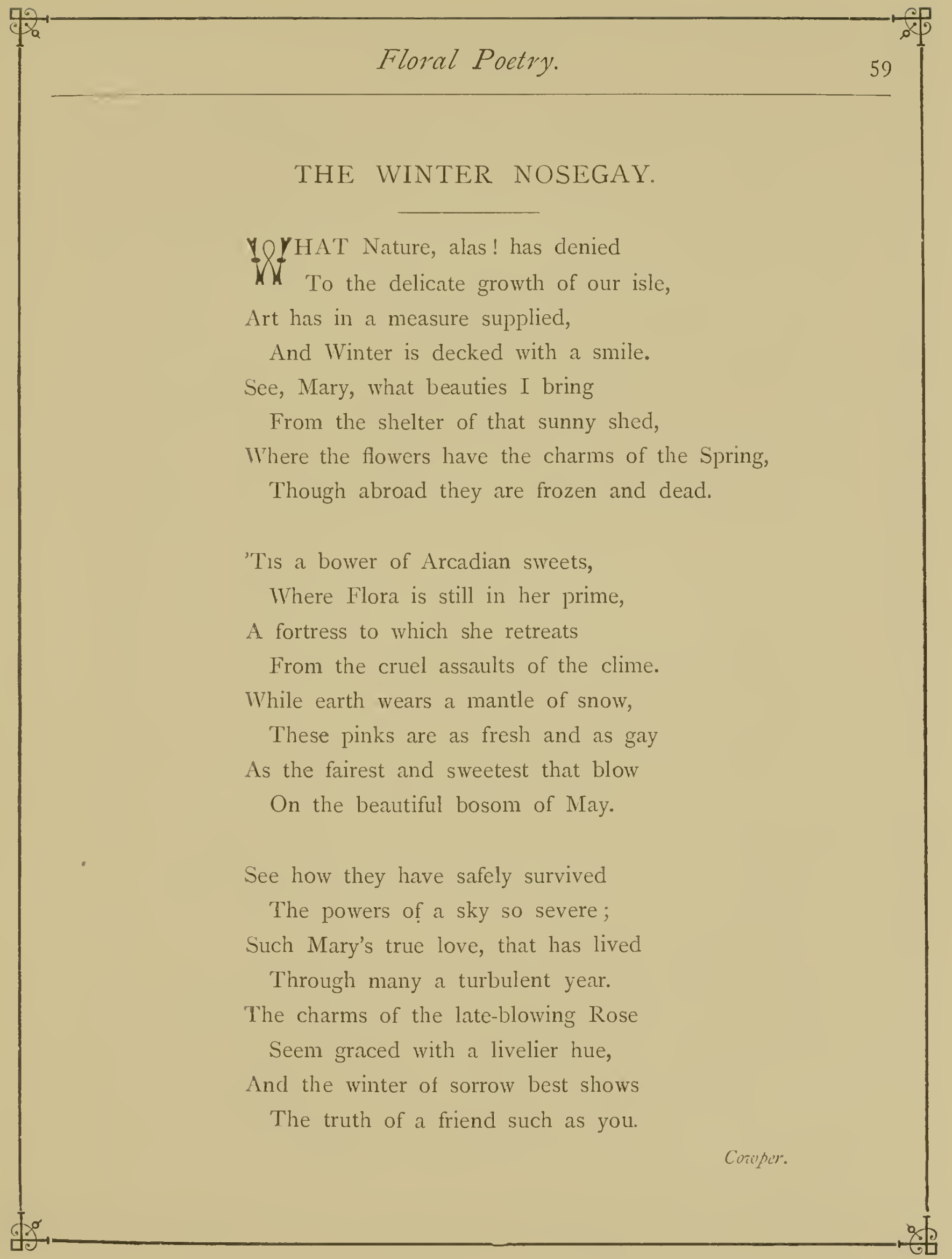




\section{FIELD FLOWERS OF SUMMER.}

YE field flowers! the gardens eclipse you, 'tis true,

A Yet, wildlings of nature, I dote upon you,

For ye waft me to summers of old,

When the earth teemed around me with fairy delight, And when Daisies and Buttercups gladdened my sight,

Like treasures of silver and gold.

I love thee for lulling me back into dreams

Of the blue Highland mountains and echoing streams,

And of birchen glades breathing their balm,

While the deer was seen glancing in sunshine remote, And the deep mellow crush of the wood-pigeon's note

Made music that sweetened the calm.

Not a pastoral song has a pleasanter tune

Than ye speak to my heart, little wildlings of June:

Of old ruinous castles ye tell,

Where I thought it delightful your beauties to find,

When the magic of nature first breathed on my mind,

And your blossoms were part of the spell.

Fven now what affections the Violet awakes!

What loved little islands, twice seen in their lakes,

Can the wild Water-lily restore!

What landscapes I read in the Primrose's looks, And what pictures of pebbled and minnowy brooks,

In the Tetches that tangled their shore! 


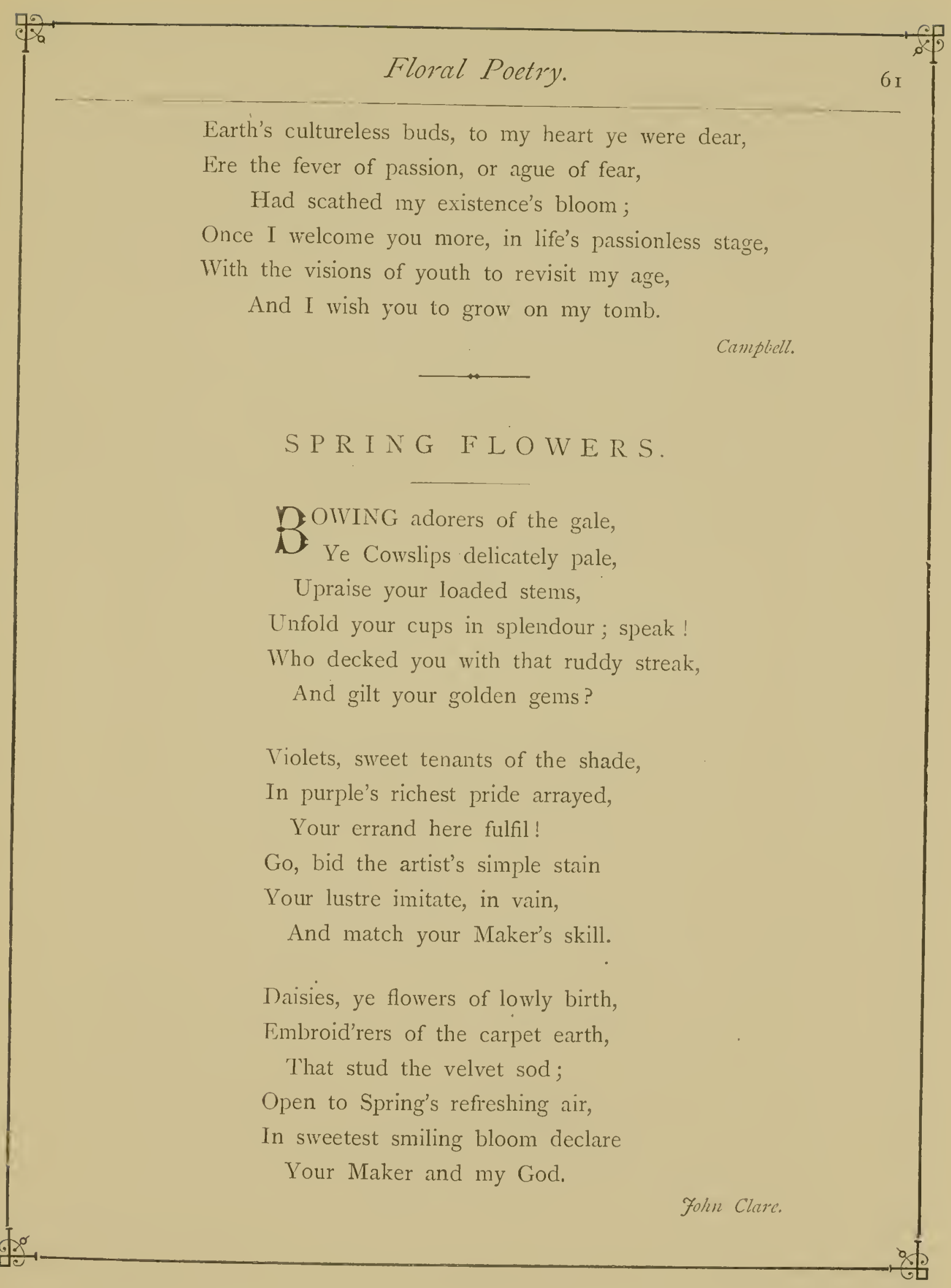




\section{I N E S}

SUGGESTED BY SOME LATE AUTUMN FLOWERS.

yrrHESE few pale Autumn flowers,

$\hat{\boldsymbol{\lambda}}$ How beautiful they are!

Than all that went before,

Than all the Summer store,

How lovelier far!

And why? they are the last!

The last! the last! the last!

Oh! by that little word

How many thoughts are stirred,

That whisper of the past.

Pale flowers! pale perishing flowers!

Ye're types of precious things :

Types of those better moments

That flit, like Life's enjoyments,

On rapid, rapid wings.

Last hours with parting dear ones

(That time the fastest spends);

Last tears in silence shed;

Last words half uttered;

Last looks of dying friends.

Who but would fain compress

A life into a day- .

The last day spent with one,

Who, ere to-morrow's sun,

Must leave us, and for aye! 
O precious, precious moments!

Pale flowers! ye're types of those:

The saddest, sweetest, dearest;

Because, like those, the nearest

To an eternal close.

Pale flowers! pale perishing flowers!

I woo your gentle breath:

I leave the Summer Rose

For younger, blither brows;

Tell me of change and death.

Anon.

\section{WITHERING! WITHERING!}

1. ITHERING-withering-all are withering!

X All of hope's flowers that youth hath nursed;

Flowers of love too early blossoming;

Buds of ambition, too frail to burst.

Faintly-faintly-oh, how faintly!

I feel life's pulses ebb and flow;

Yet sorrow, I know thou dealest daintily,

With one who should not wish to live moe.

Nay! why, young heart, thus timidly shrinking?

Why doth thy upward wing thus tire?

Why are thy pinions so droopingly sinking,

When they should only waft thee higher?

Upward-upward-let them be waving,

Lifting the soul toward her place of birth;

There are guerdons there, more worthy thy having,

Far more than any these lures of the earth.

IToffman. 


\section{THE DEATH OF THE FLOWERS.}

YruHE melancholy days are come, the saddest of the year,

$\boldsymbol{\lambda}$ Of wailing winds, and naked woods, and meadows brown and sere;

Heaped in the hollows of the grove, the withered leaves lie dead;

They rustle to the eddying gust, and to the rabbit's tread.

The robin and the wren are flown, and from the shrub the jay,

And from the wood-top calls the crow, through all the gloomy day.

Where are the flowers, the fair young flowers, that lately sprung and stood In brighter light and softer airs, a beauteous sisterhood?

Alas! they all are in their graves-the gentle race. of flowers

Are lying in their lowly beds, with the fair and good of ours.

The rain is falling where they lie; but the cold November rain

Calls not from out the gloomy earth, the lovely ones again.

The Wind-flower and the Violet, they perished long ago;

And the Wild-rose and the Orchis died amid the Summer glow;

But on the hill the Golden-rod, and the Aster in the wood,

And the yellow Sunflower by the brook, in Autumn beauty stood.

Till fell the frost from the clear cold heaven, as falls the plague on men, And the brightness of their smile was gone from upland glade and glen.

And now, when comes the calm mid-day, as still such days will come, To call the squirrel and the bee from out their wintry home;

Where the sound of dropping nuts is heard, though all the leaves are still, And twinkle in the smoky light the waters of the rill.

The south-wind searches for the flowers whose fragrance late he bore, And sighs to find them in the wood, and by the stream, no more.

And then I think of one, who in her youthful beauty died;

The fair meek blossom that grew up and faded by my side;

In the cold moist earth we laid her, when the forest cast the leaf,

And we wept that one so lovely should have a life so brief;

Yet not unmeet it was, that one like that young friend of ours,

So gentle and so beautiful, should perish with the flowers. 


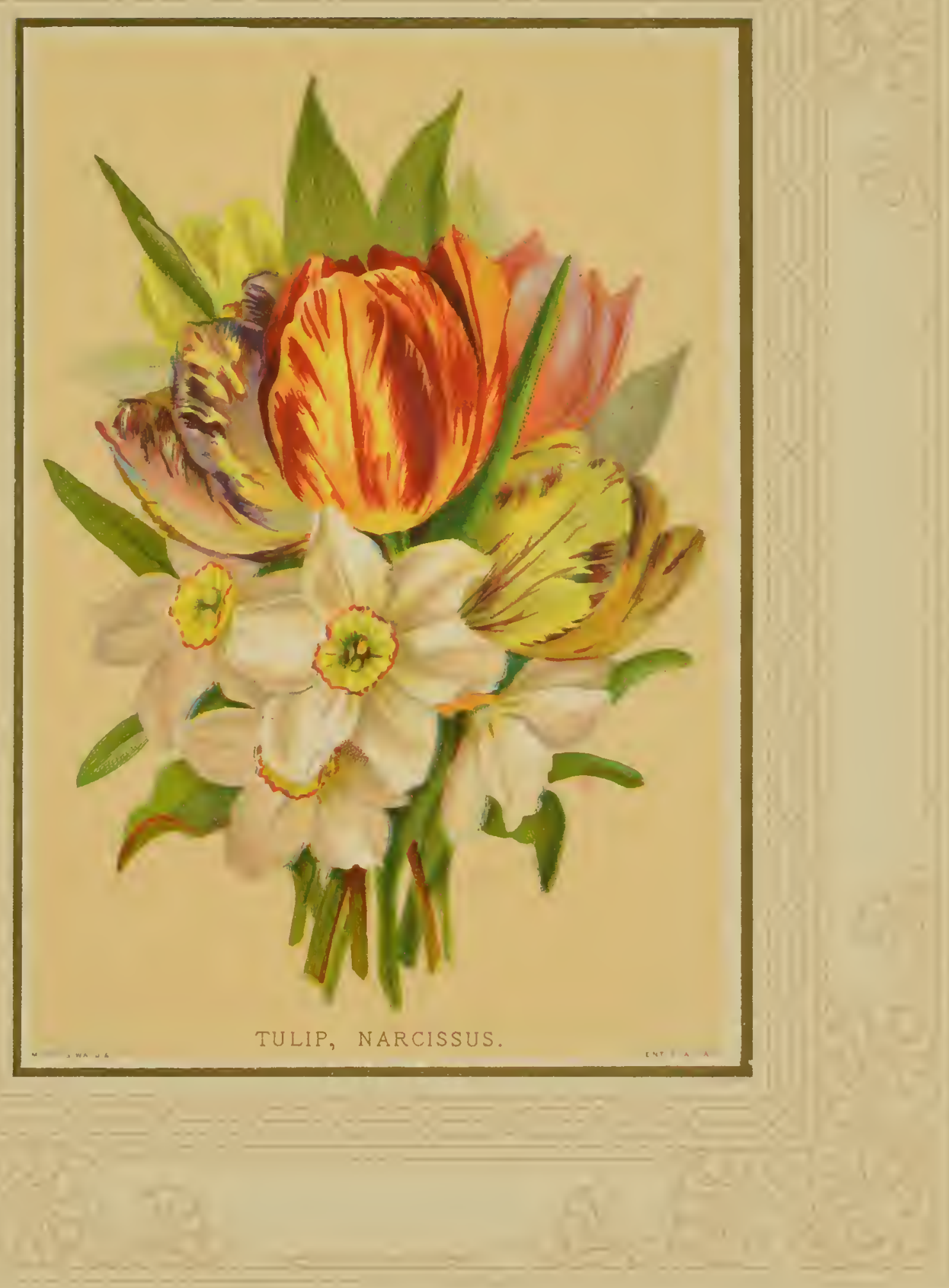





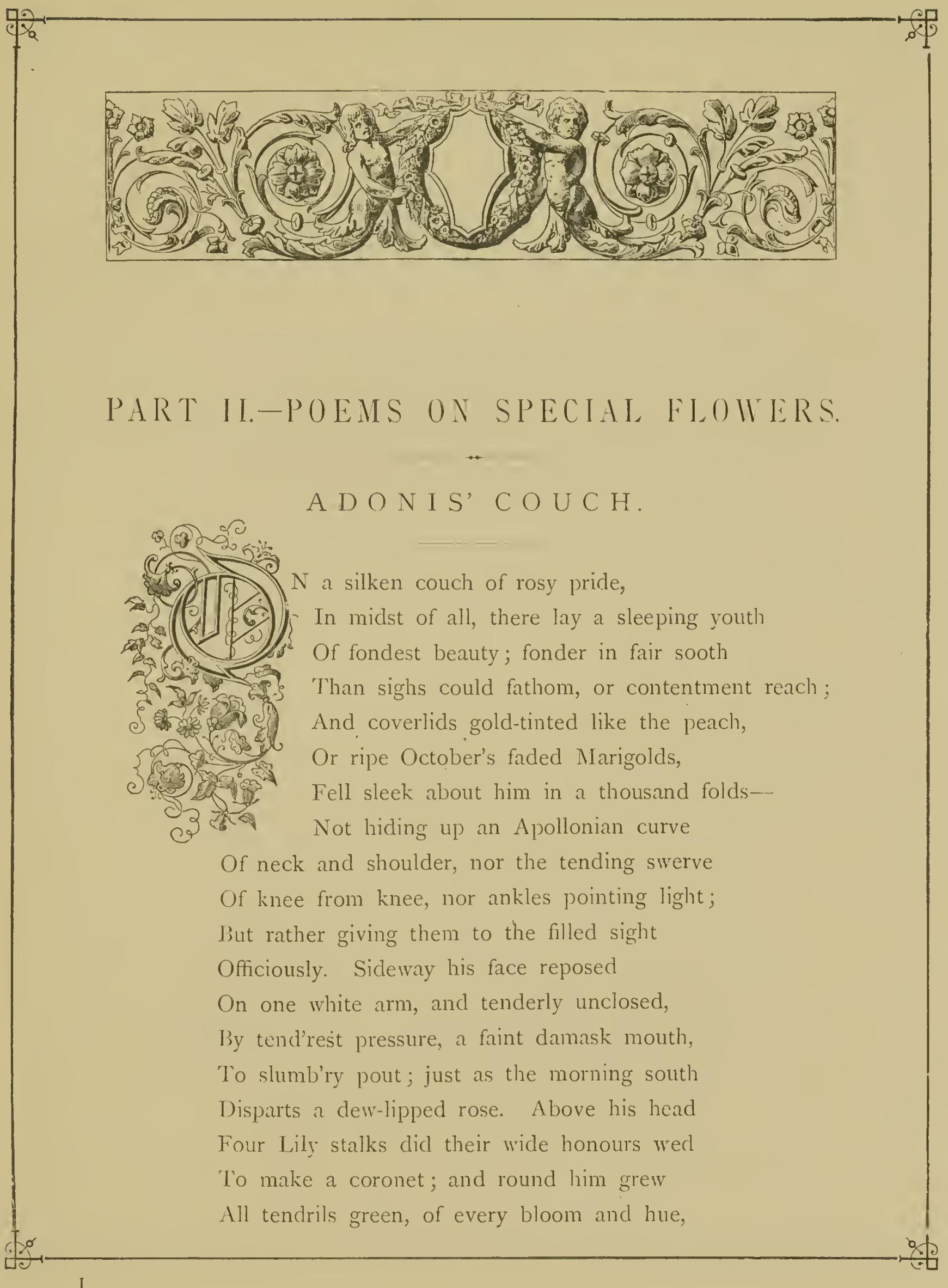




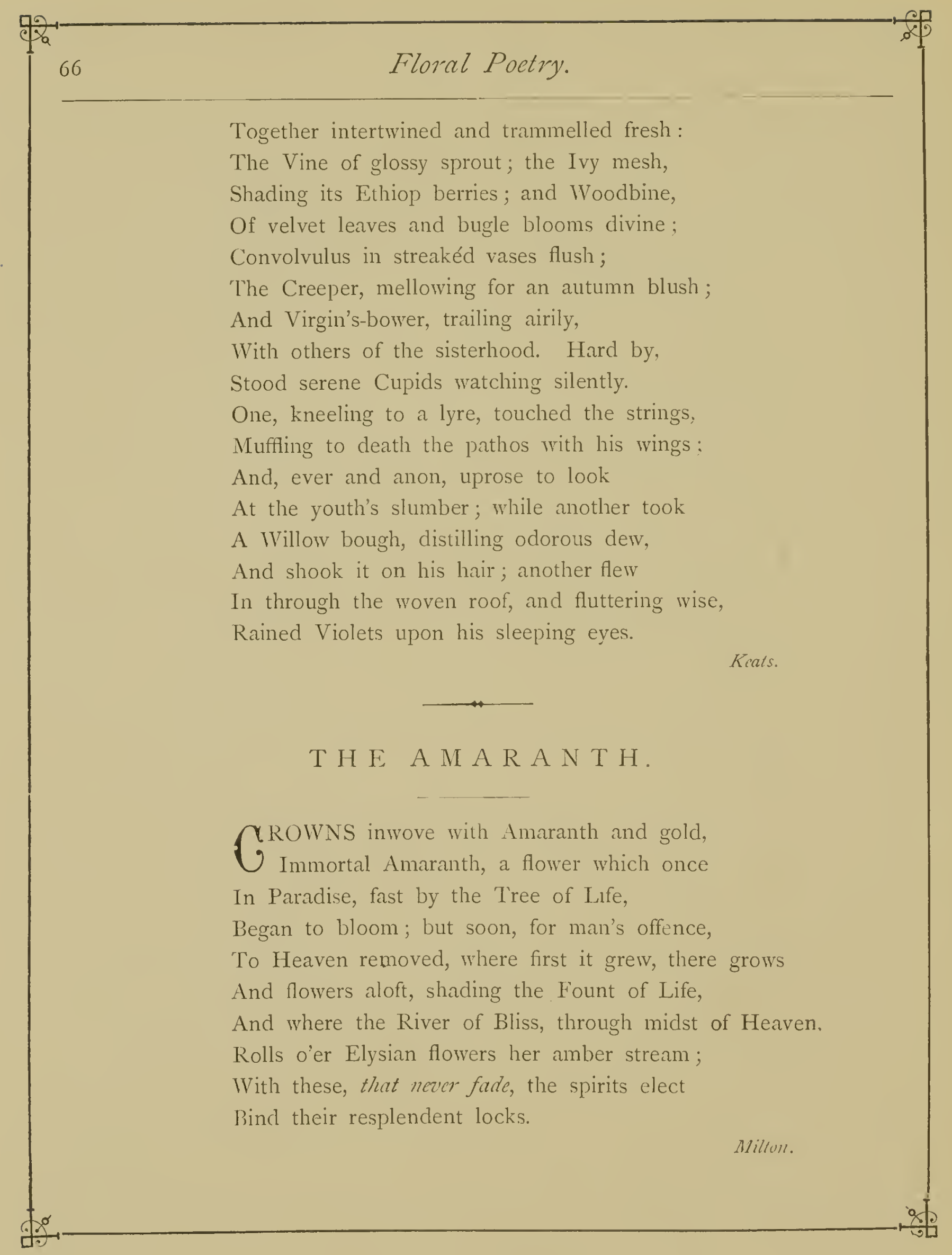




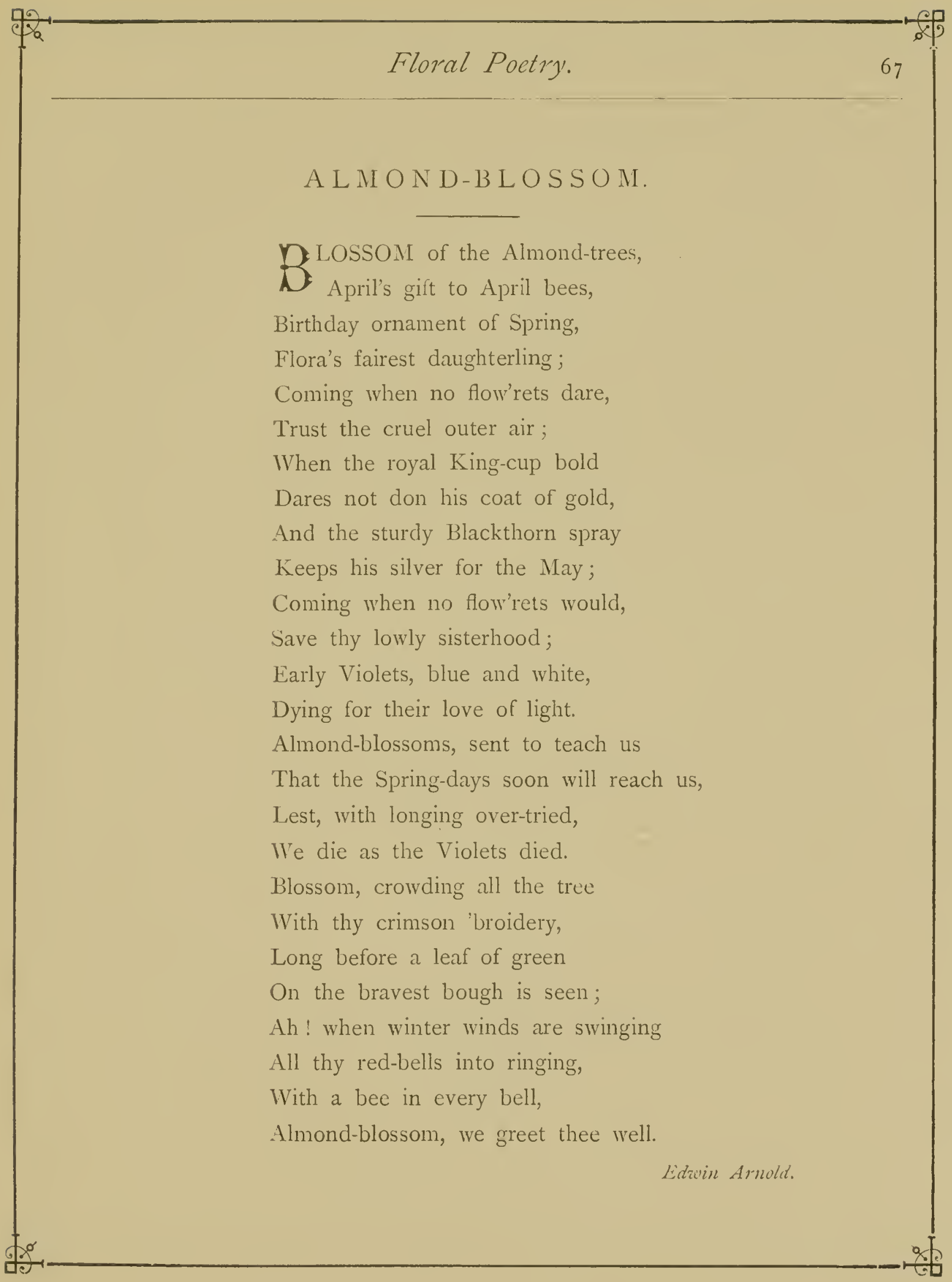




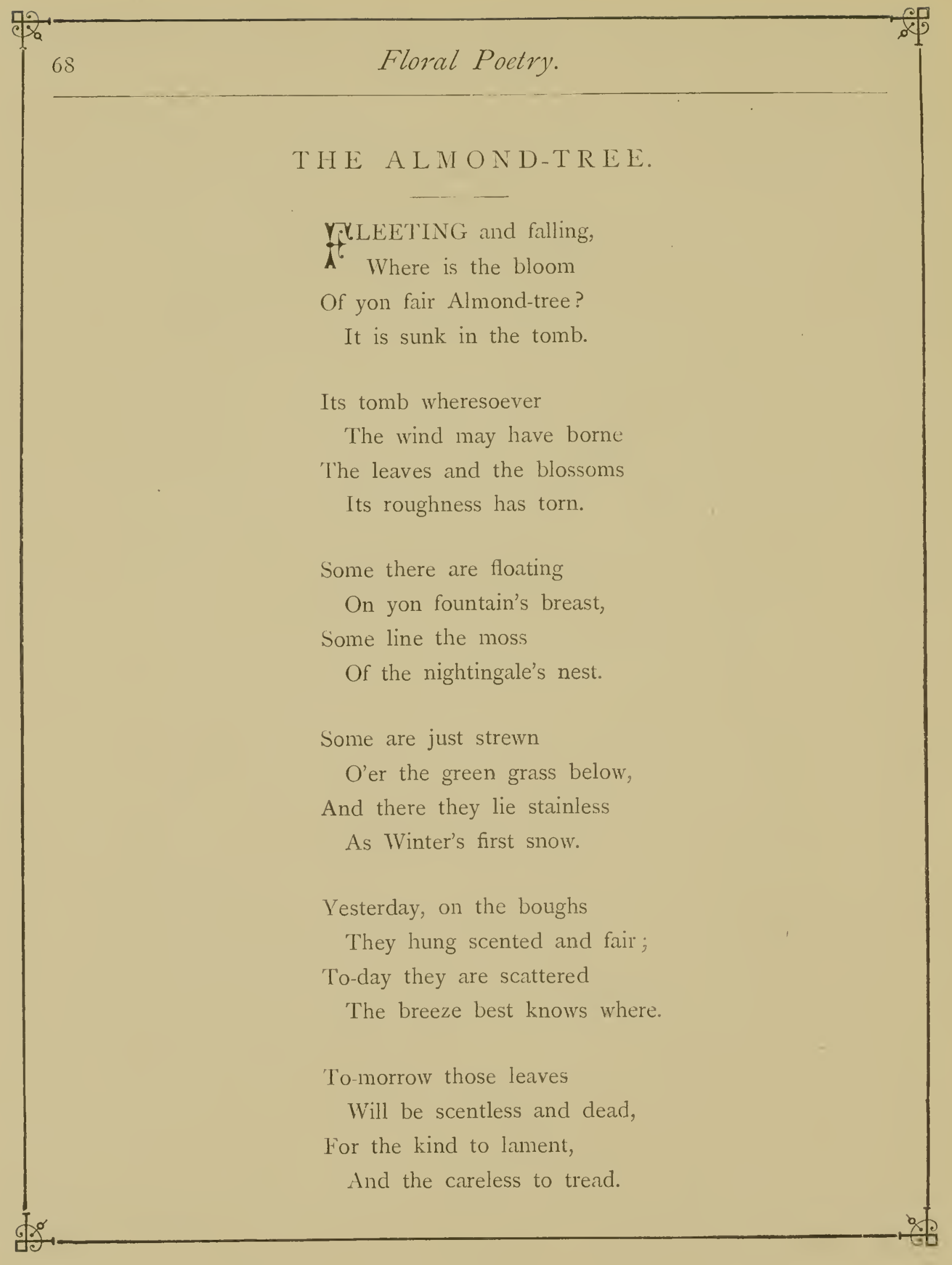




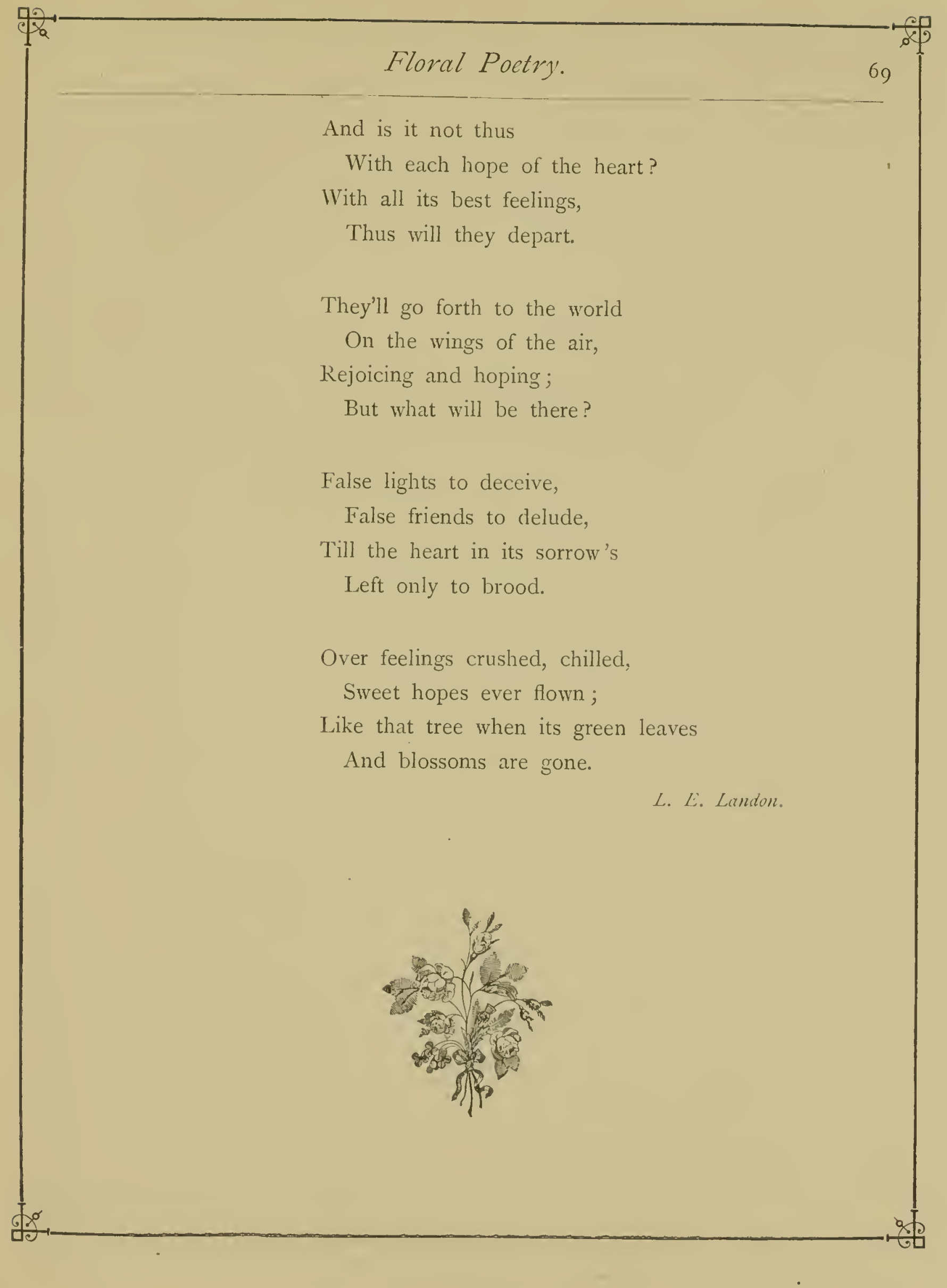




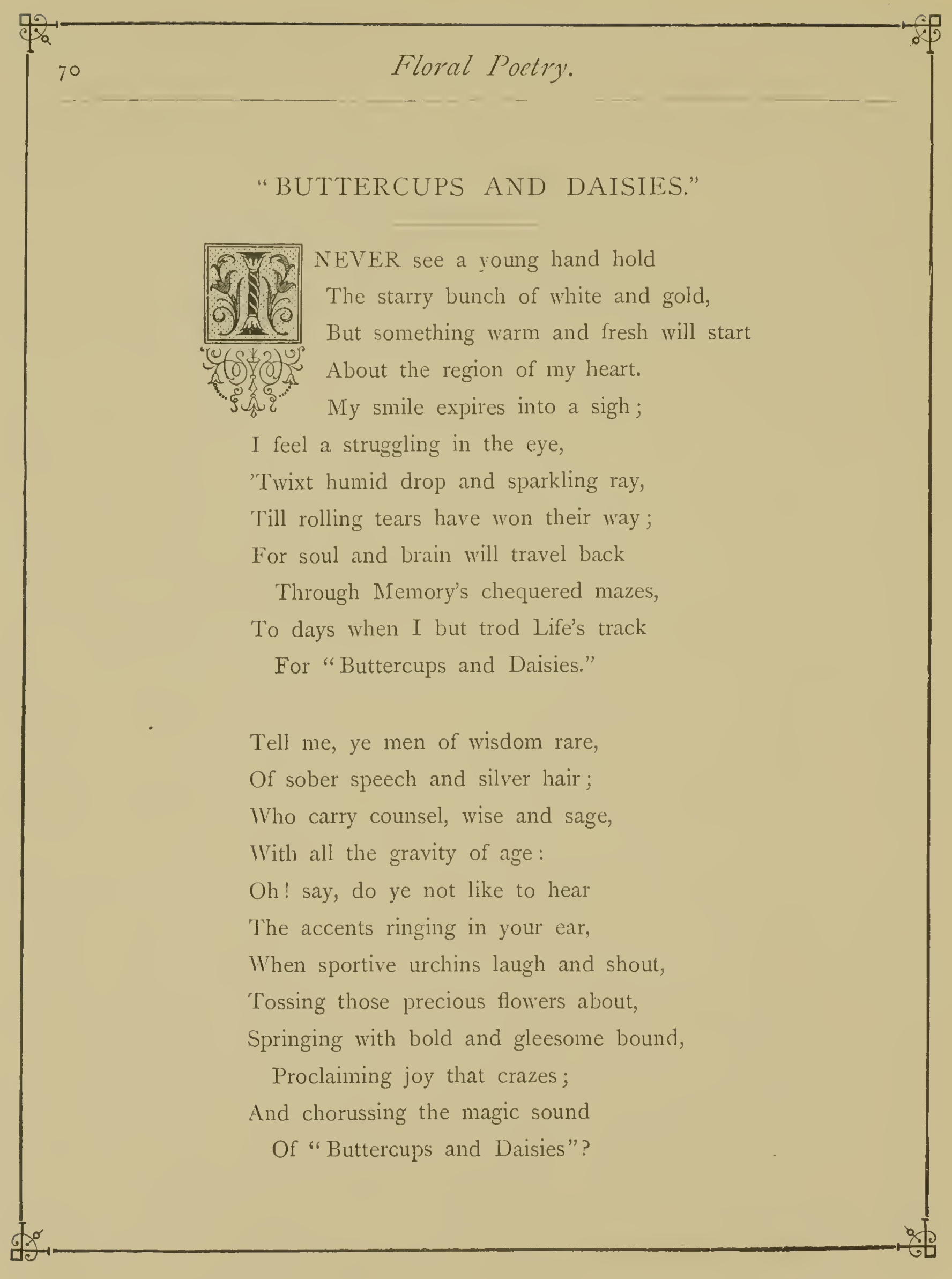




\section{Floral Poetry.}

Are there, I ask, beneath the sky

Blossoms that knit so strong a tie

With childhood's love? Can any please

Or light the infant eye like these?

No, no; there's not a bud on earth

Of richest tint, or warmest birth,

Can ever fling such zeal and zest,

Into the tiny hand and breast.

Who does not recollect the hours

When burning words and praises

Were lavished on those shining flowers,

"Buttercups and Daisies"?

There seems a bright and fairy spell

About their very names to divell;

And though old Time has marked my brow

With care and thought, I love them now.

Smile, if ye will, but some heart-strings

Are closest linked to simplest things;

And these wild flowers will hold mine fast.

Till love, and life, and all be past;

And then the only wish I have

Is, that the one who raises

The turf-sod o'er me plant my grave

IVith "Buttercups and Daisies."

Eliza Cook. 


\section{TO THE BRAMBLE FLOWER.}

yr.HY fruit full well the schoolboy knows,

$\boldsymbol{A}$ Wild Bramble of the brake!

So, put thou forth thy small white Rose;

I love it for his sake.

Though Woodbines flaunt and Roses glow

O'er all the fragrant bowers,

'Thou need'st not be ashamed to show

Thy satin-threaded flowers;

For dull the eye, the heart is dull

That cannot feel how fair,

Amid all beauty, beautiful

Thy tender blossoms are!

How delicate thy gauzy frill !

How rich thy branchy stem!

How soft thy voice when woods are still,

And thou sing'st hymns to them!

While silent showers are falling slow,

And, 'mid the general hush,

A sweet air lifts the little bough,

Lone whispering through the bush!

"The Primrose to the grave is gone;

The Hawthorn flower is dead;

The Violet by the mossed grey stone

Hath laid her weary head; 


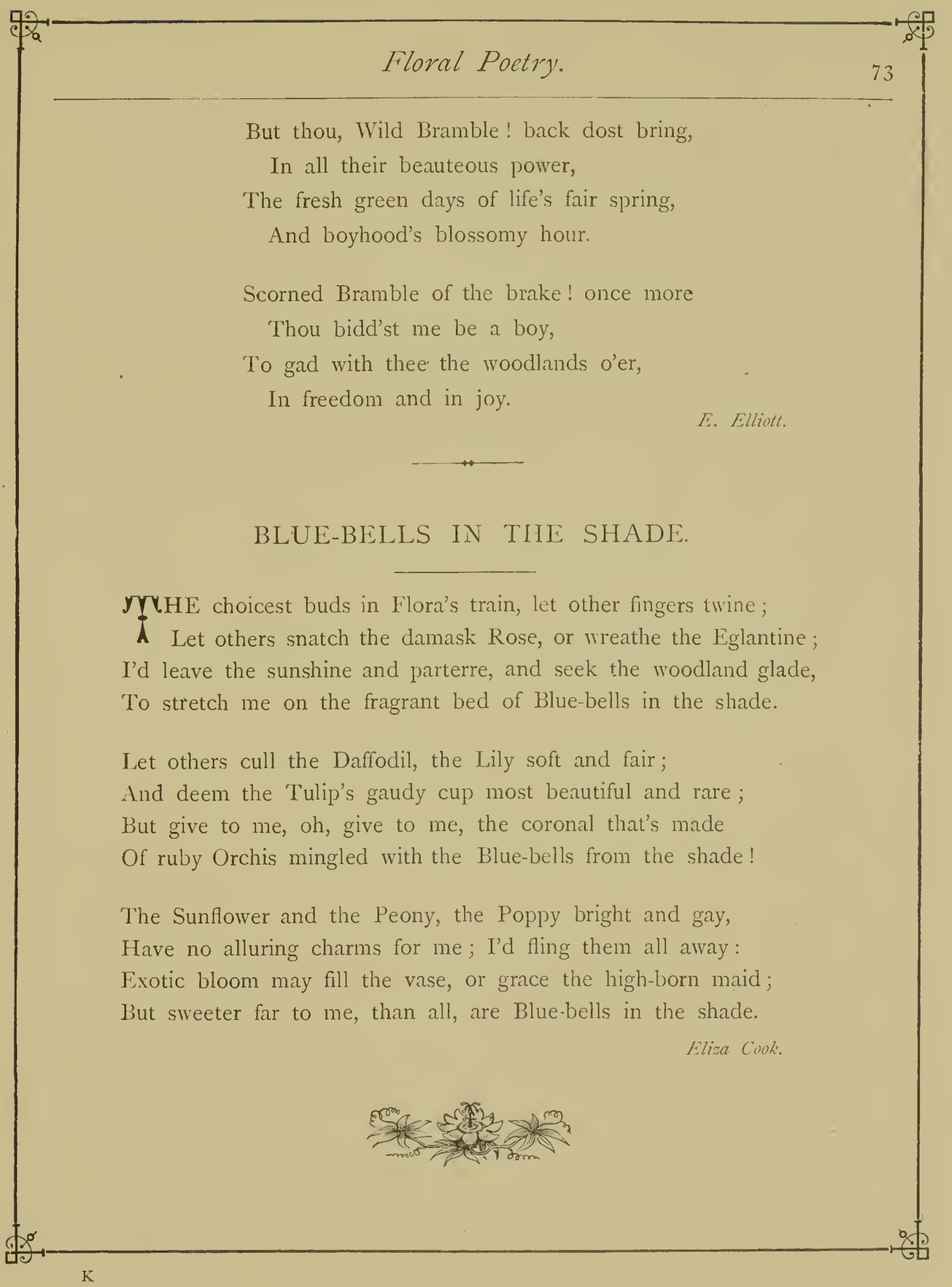




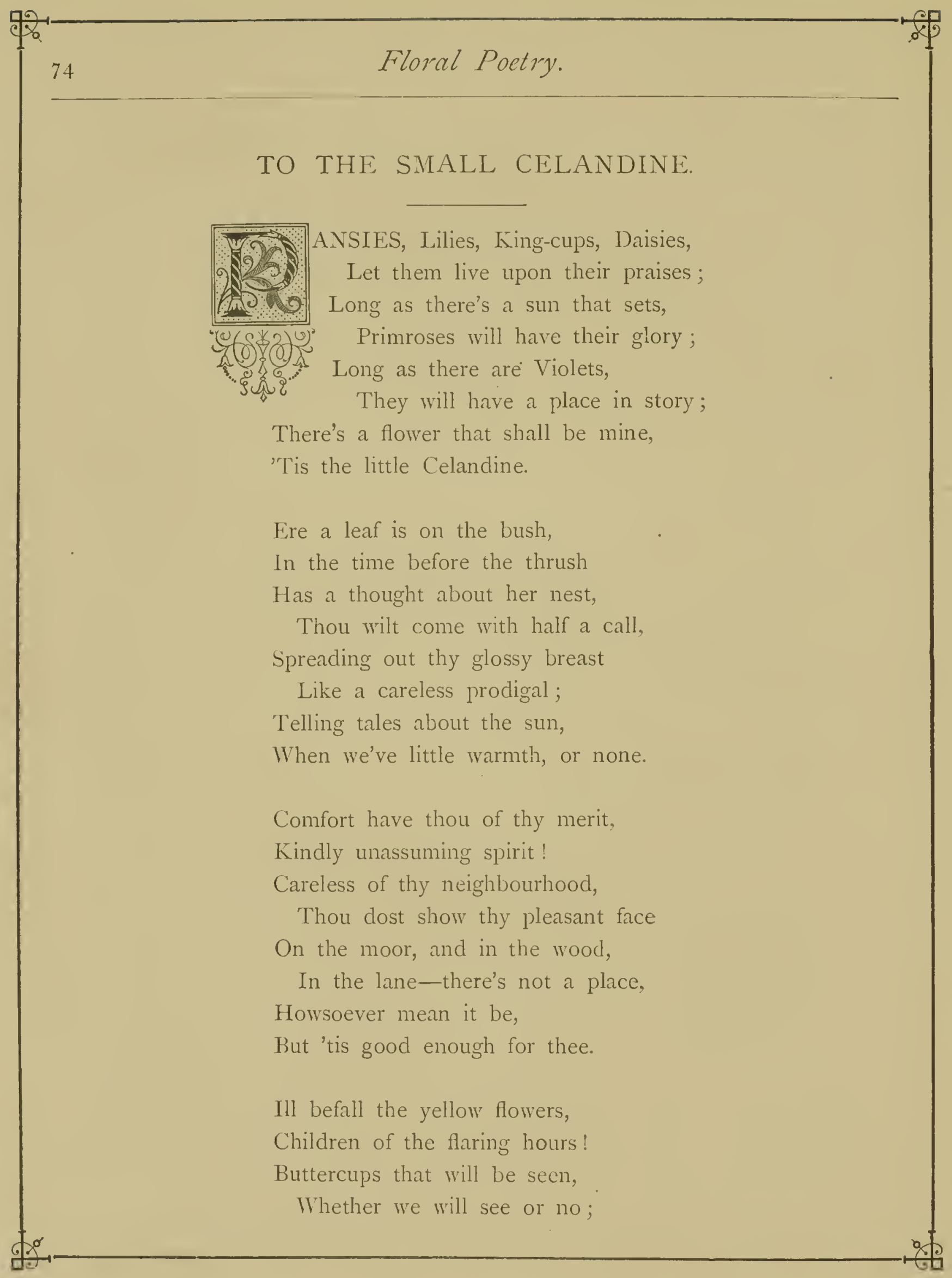




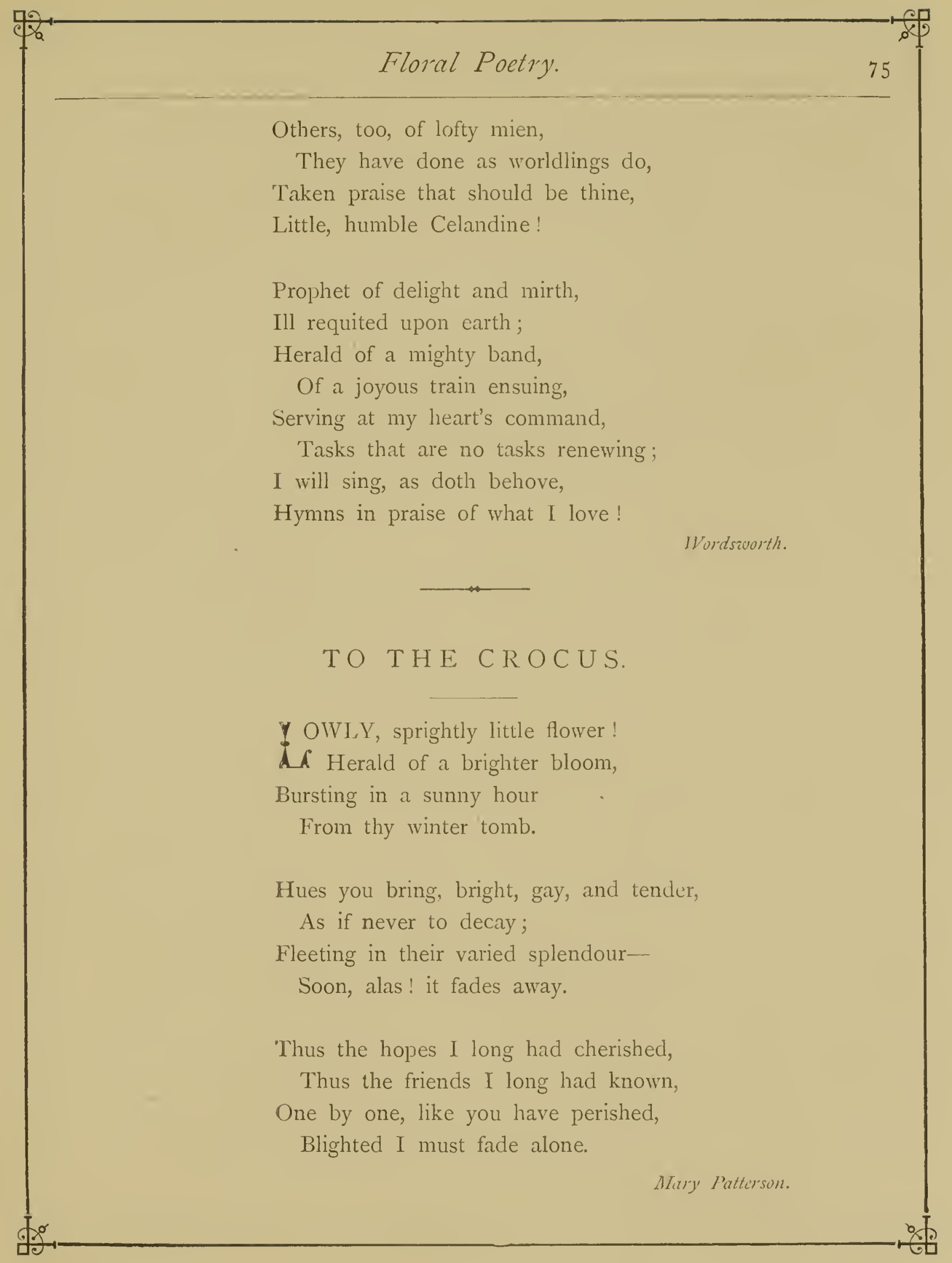




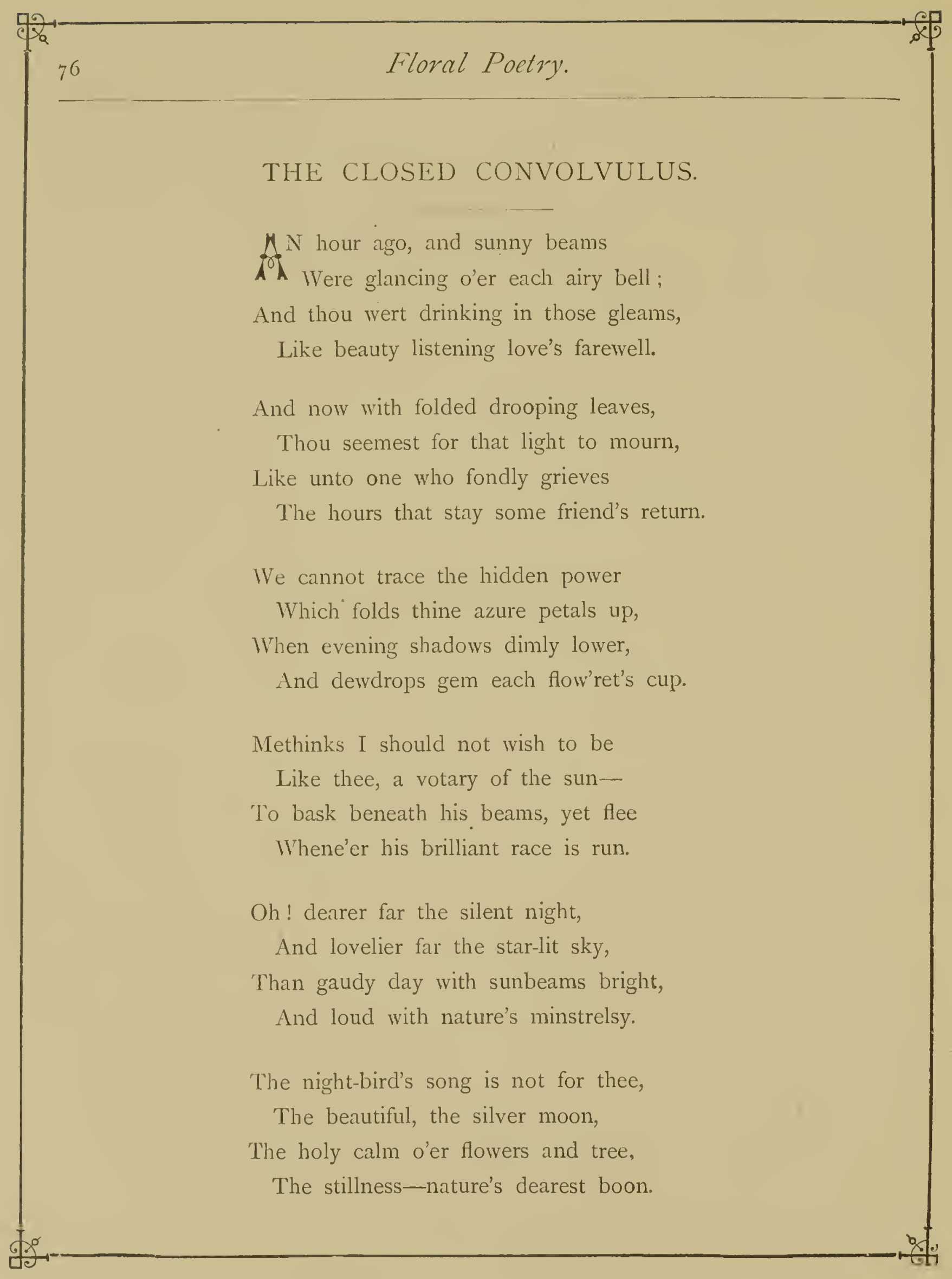




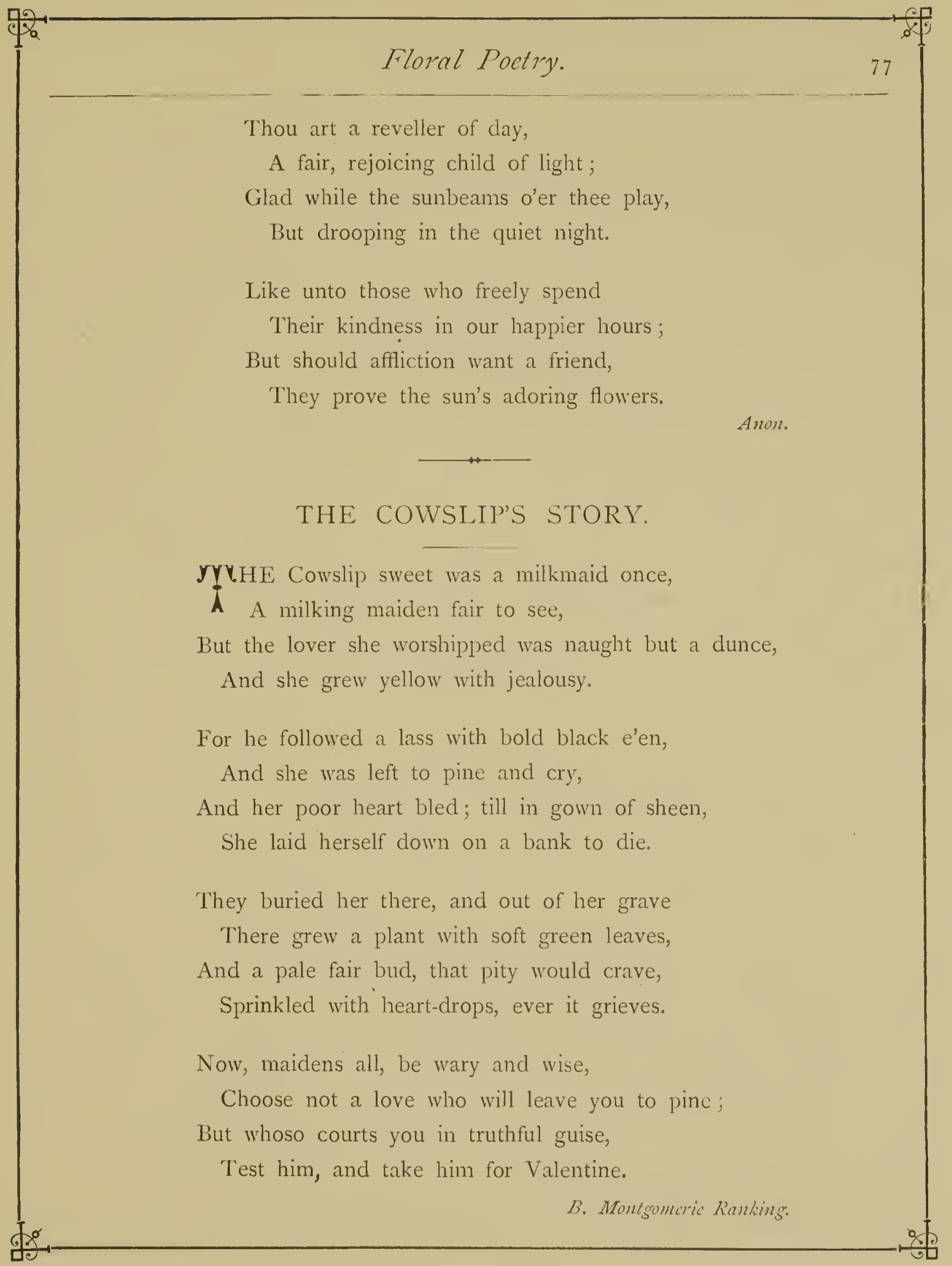




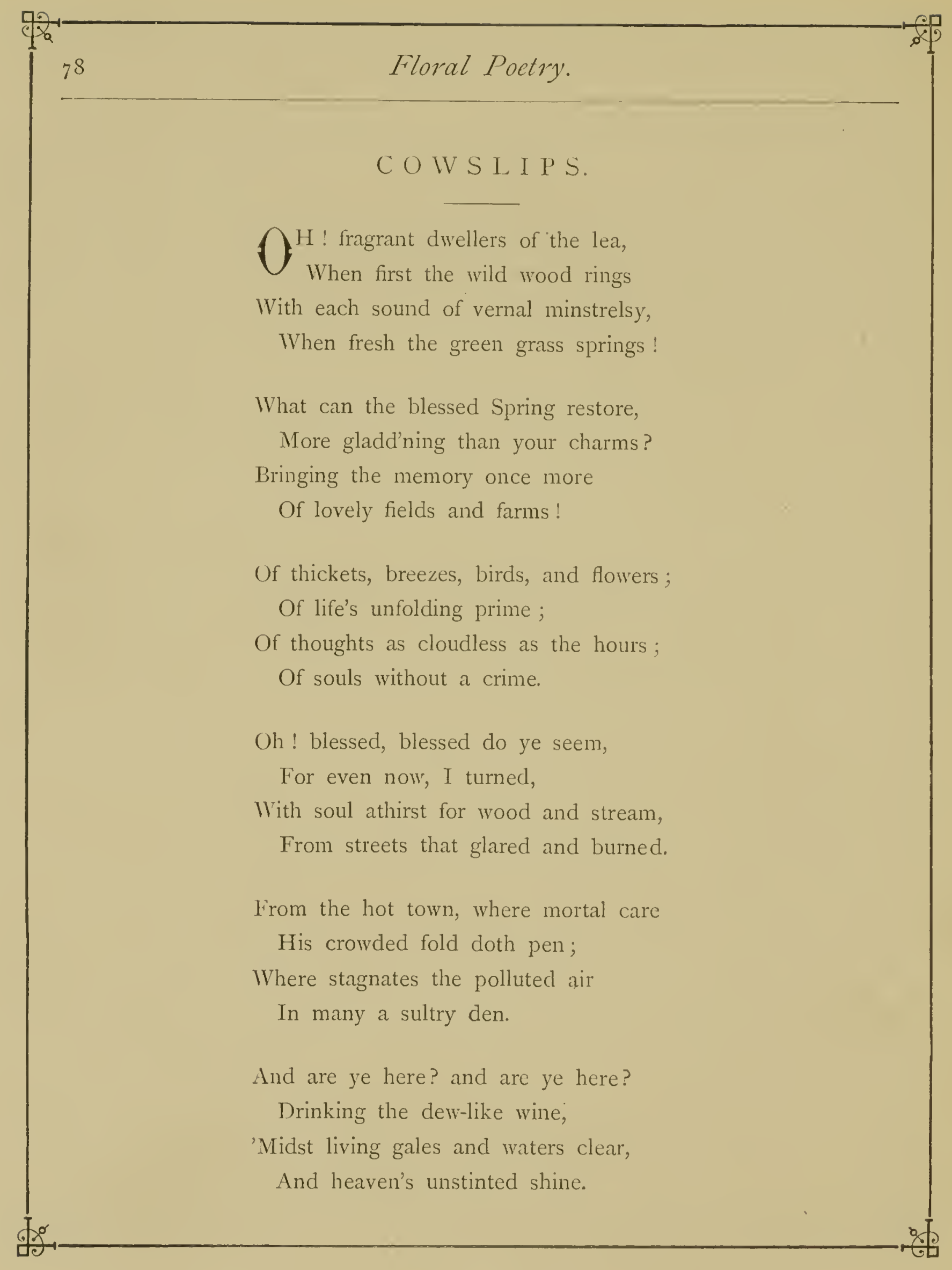




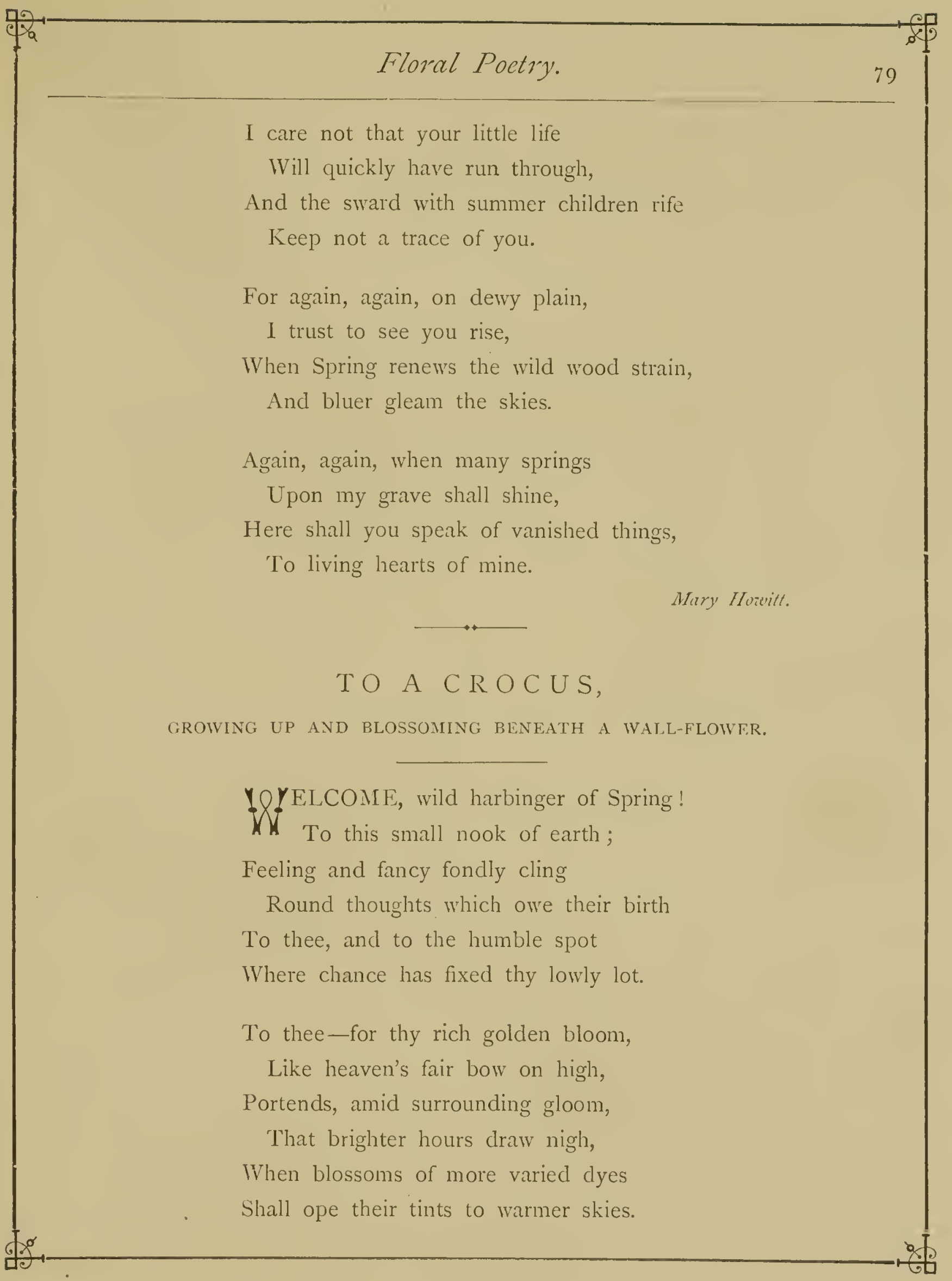




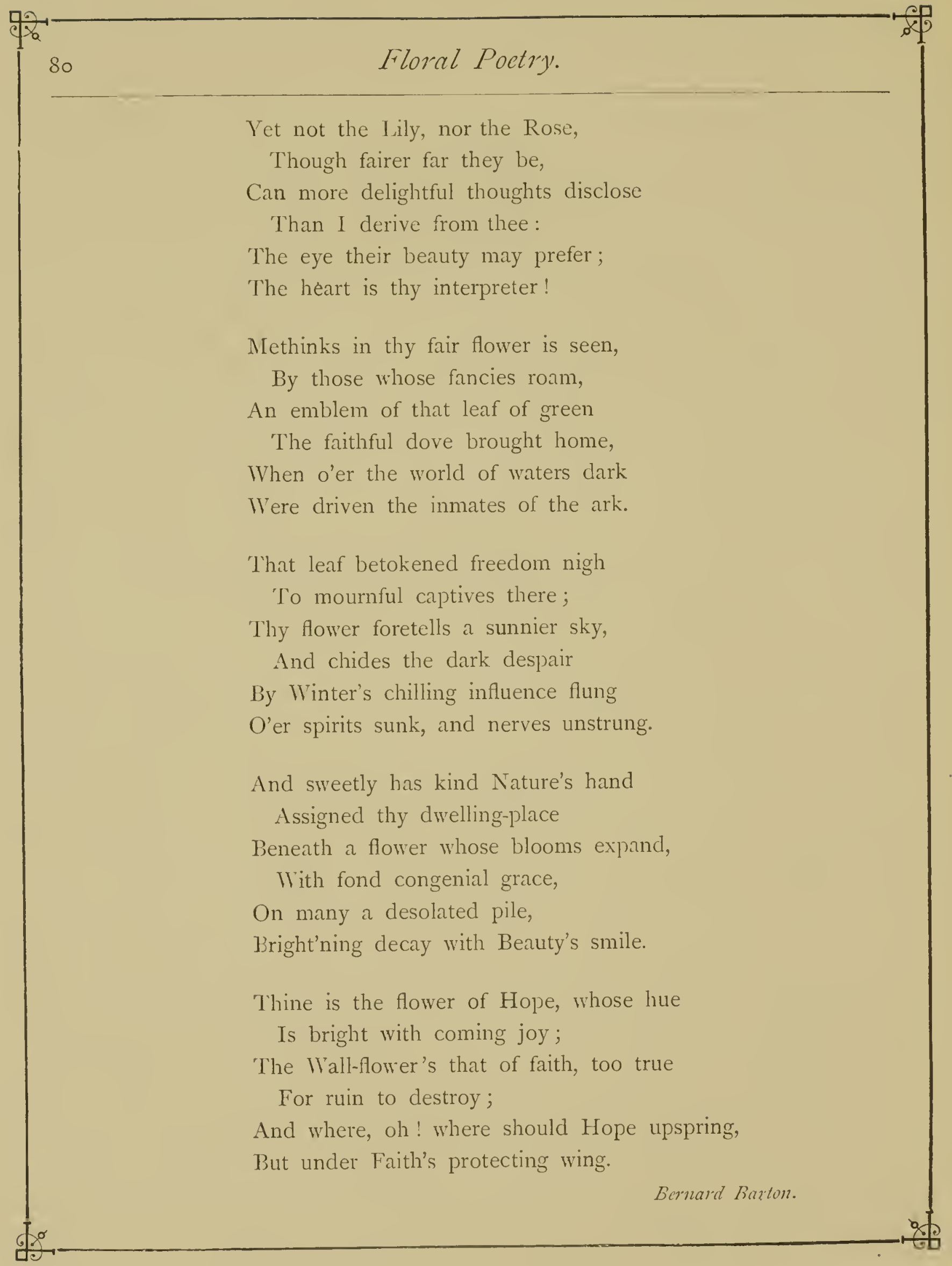




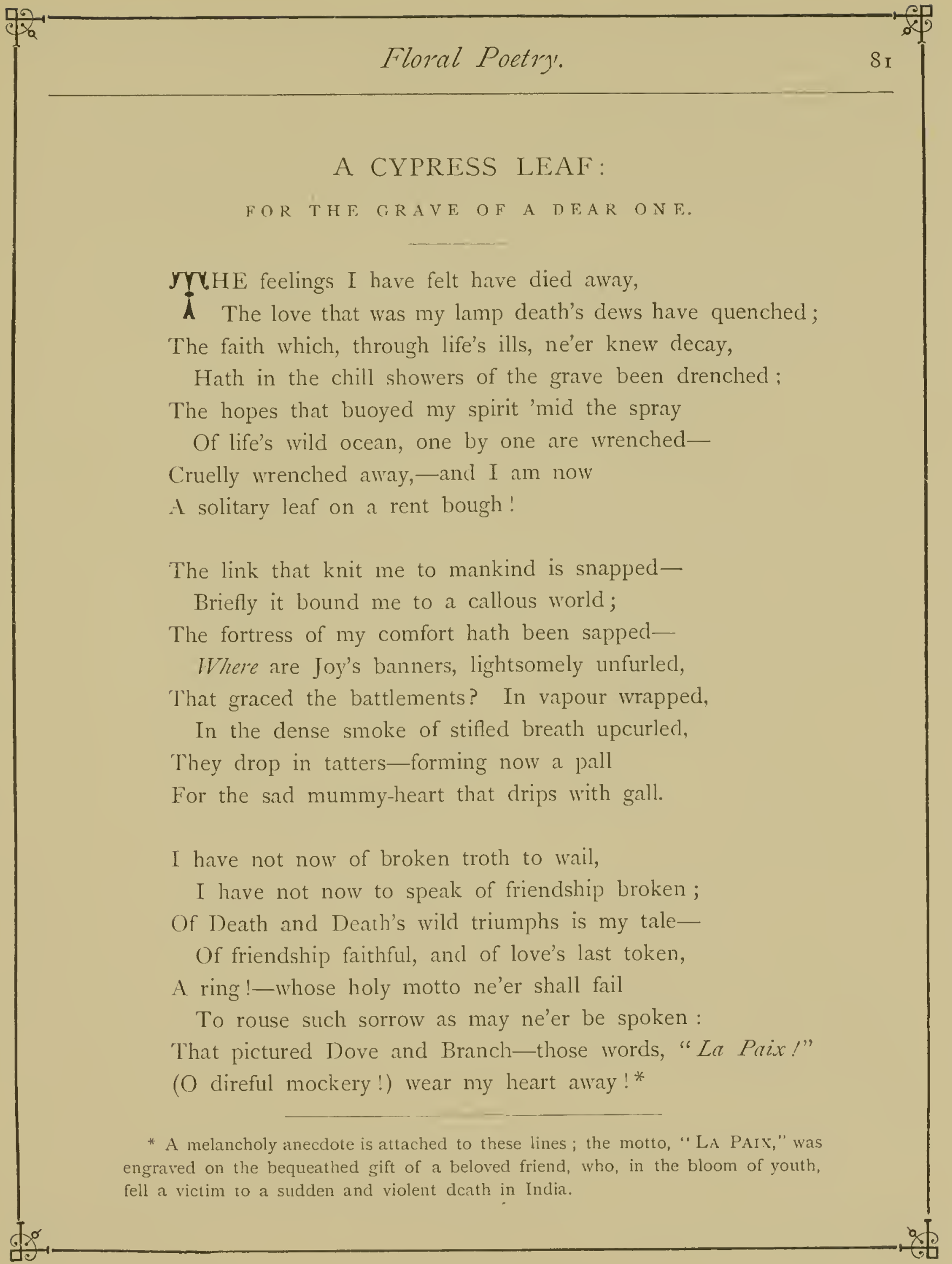

I. 
"Peace?"-Peace! alas, there is no peace for me.

It rests with thee, belov'd one, in the grave!

Yet, when I search the cells of Memory,

Where silently the subterranean wave

of buried hope glides on, a thought of thee-

Like sunshine on the hermit's darkened cave-

Steals gently o'er my spirit, whispering sweet

Of realms beyond the tomb, where we shall meet:

Our love-how did it spring? In sooth it grew,

Even as some rare exotic in a clime

Unfriendly to its growth: yet rich in hue,

Voluptuous in fragrance, as if Time

Had been to it all sunlight and soft dew,--

As if upon its freshness the cold rime

Of death should never fall! How came it, then?

Even as the manna fell 'midst famished men,

To be snatched up in transport! And we fed

Upon affection's banquet, that ne'er palled

Upon the spirit's palate! Friendship shed

A light around our bosoms, which recalled

The memory of that bard whose soul was wed-

With love surpassing woman's love, ungalled

By selfish doubts - to him, the monarch's son,

Brave Jonathan! Like theirs, our souls were one.

Oh! long we loved in silence! Neither spake

Of that which worked the thoughtful mine within;

Thou didst not guess that, sleeping or awake,

My thoughts were full of thee till thought grew $\sin$ : 
For it is sin of earthly things to make

Our idols; and I never hoped to win

Thy coveted affection; but for me,

Thy heart was also yearning silently!

I was the first to speak-and words there were,

Wild words that painted fond affection's course;--

Oh! what indeed will erring tongues not dare,

When conquering Feeling prompts! Like winds that force

From wind-harps mystic sounds, the lips declare

Thoughts that are often followed by remorse;

For passion hath a potency that breaks

Each puny bulwark callous Reason makes!

But ours was Friendship's purest worship-pure,

Altho' that worship bowed at earthly shrines;

Alas! that hearts on altars insecure

Should sacrifice their all of bliss! There twines

O'er mankind's sweetest hopes corruption sure,

To blast their beauty e'en whilst most it shines :-

'Tis but to teach us there are worlds above,

Where Hope fruition finds in endless Love!

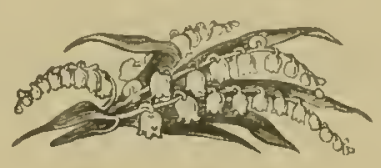




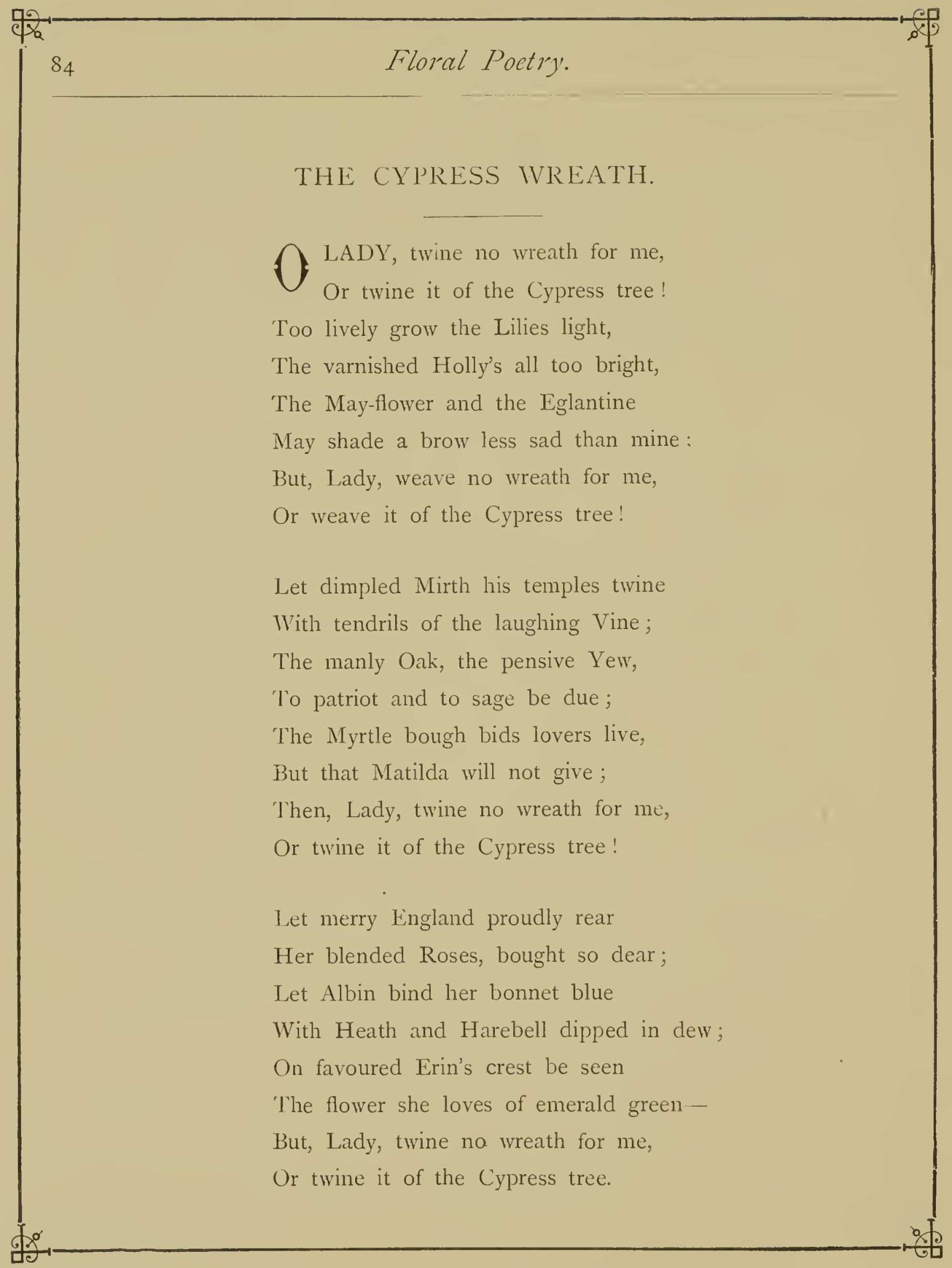




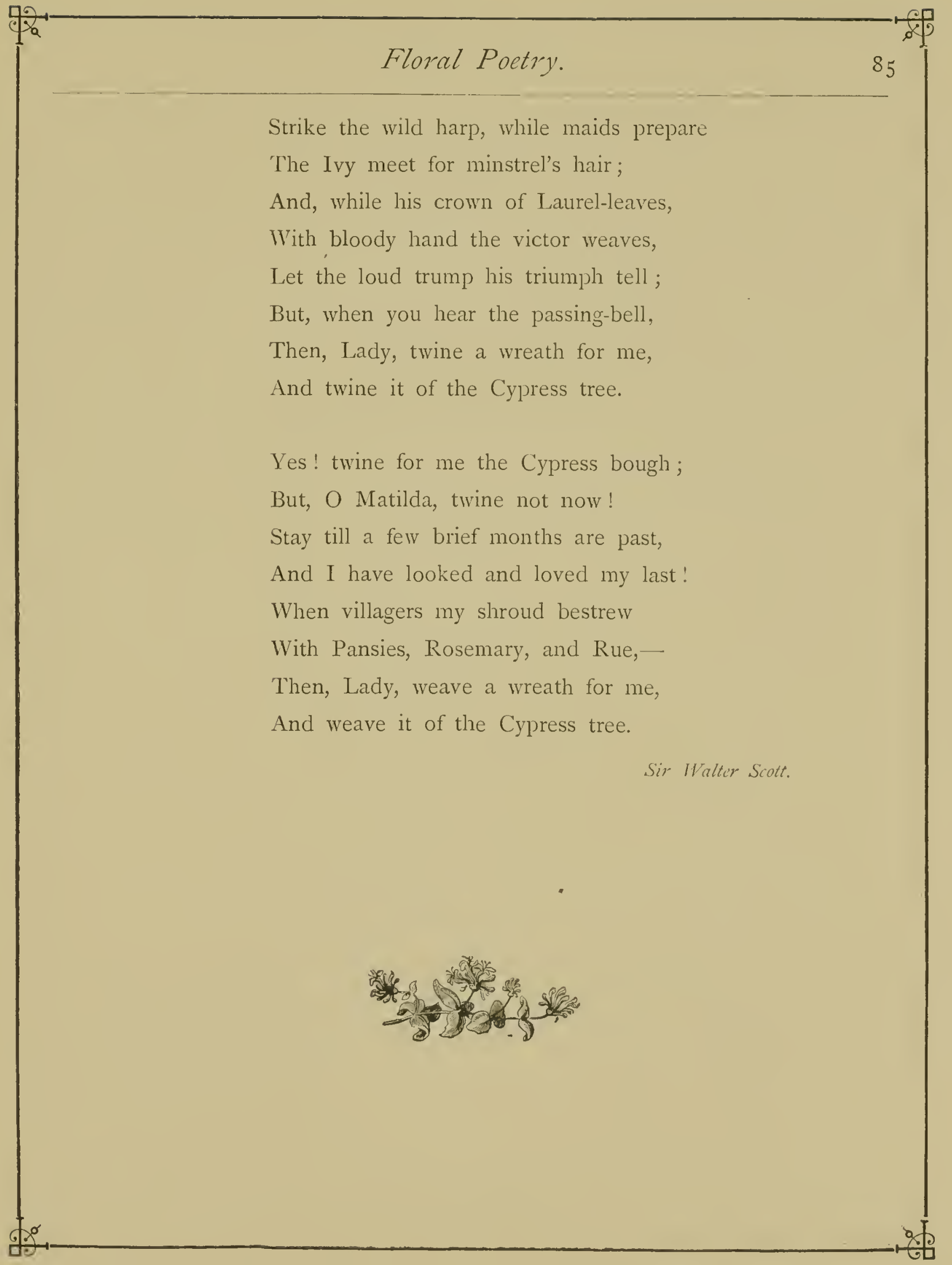




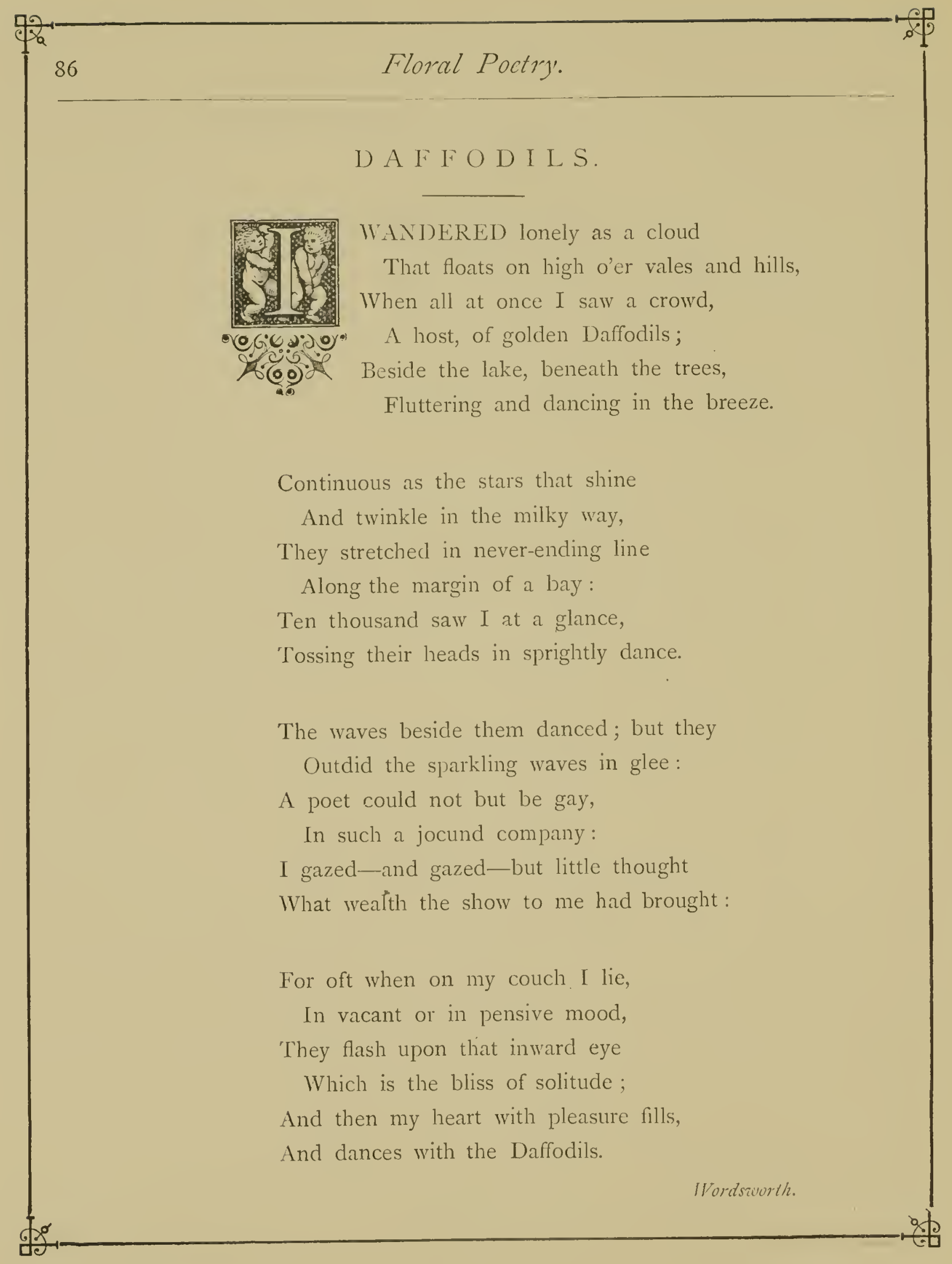




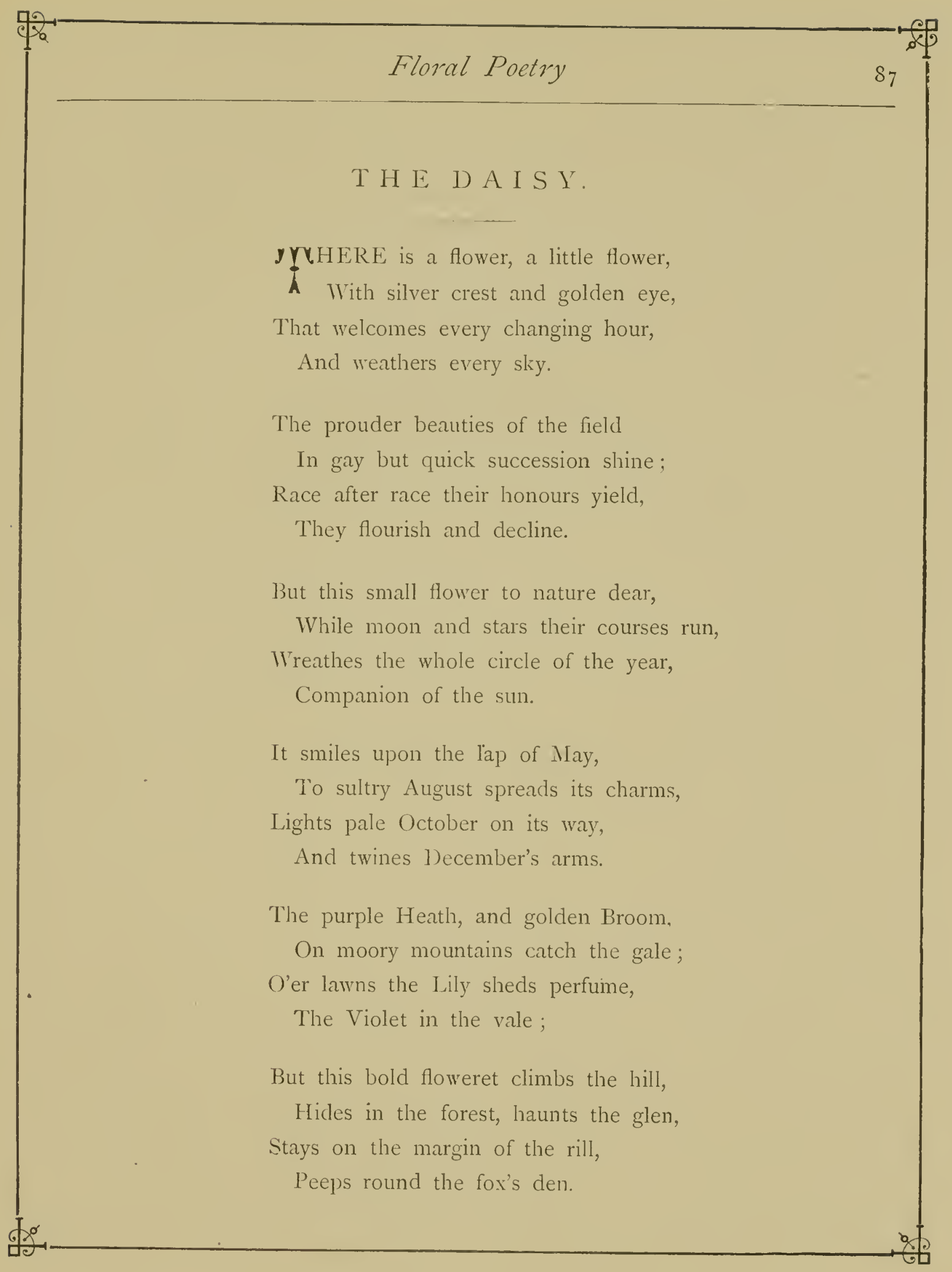




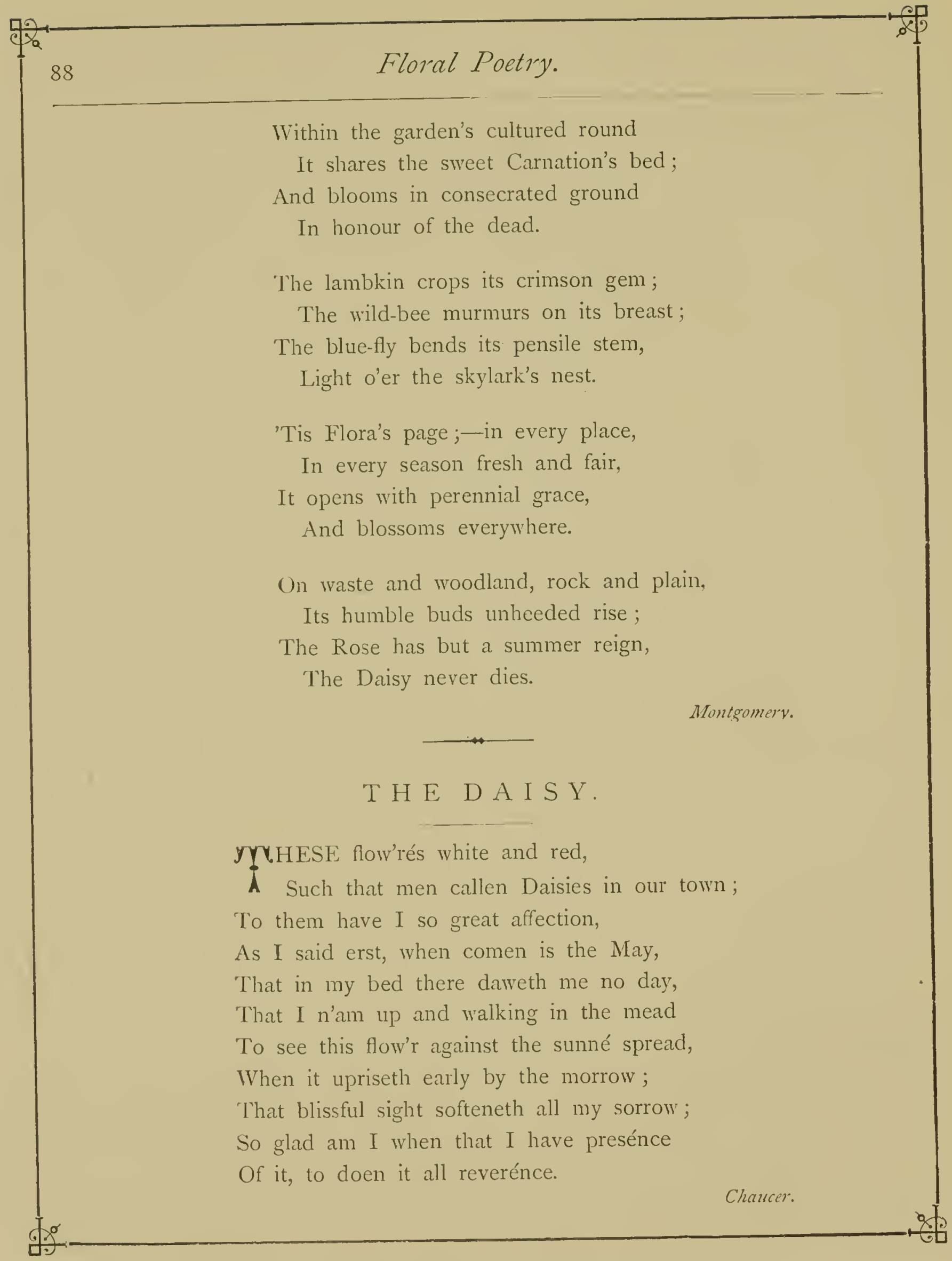




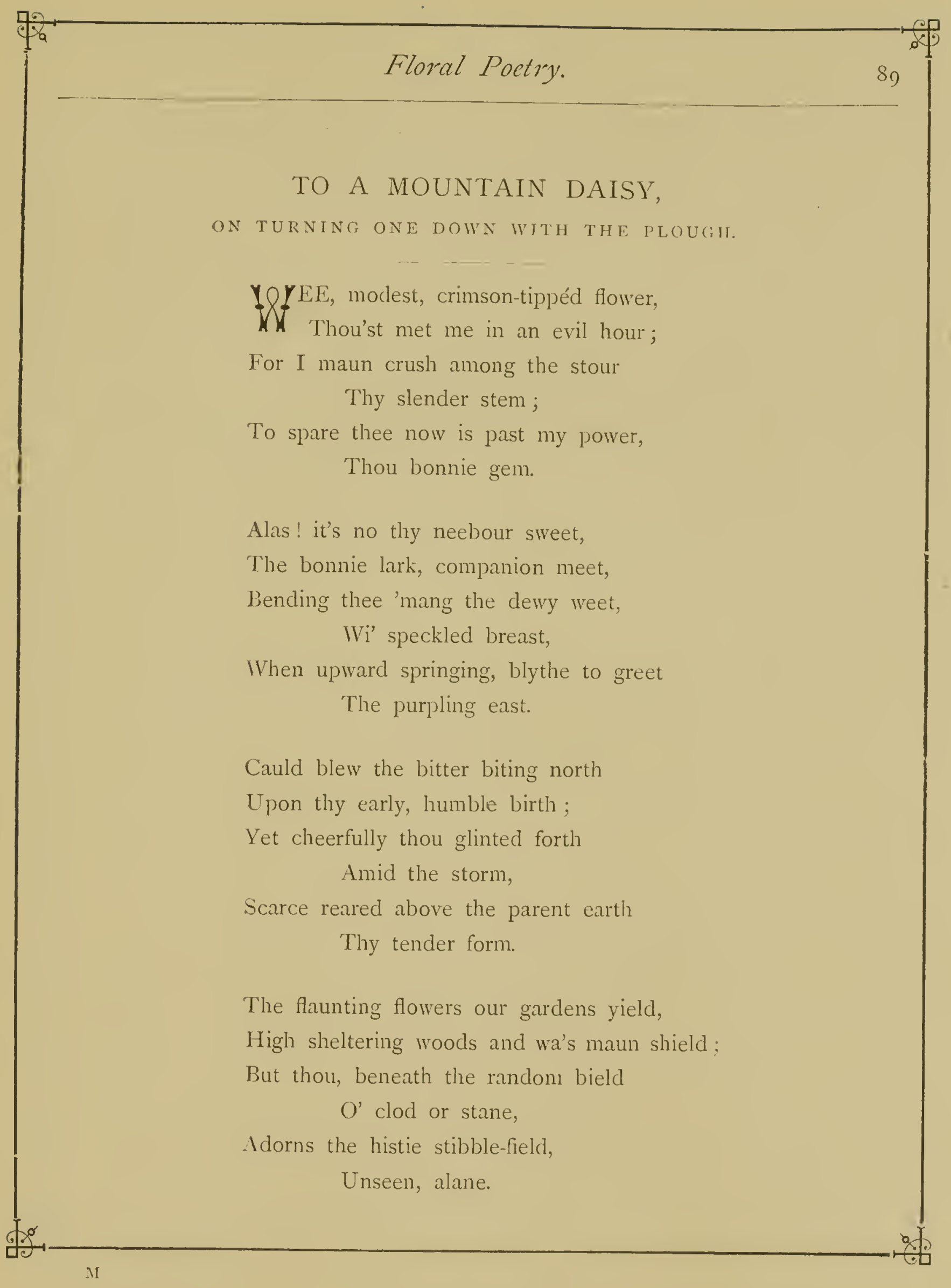




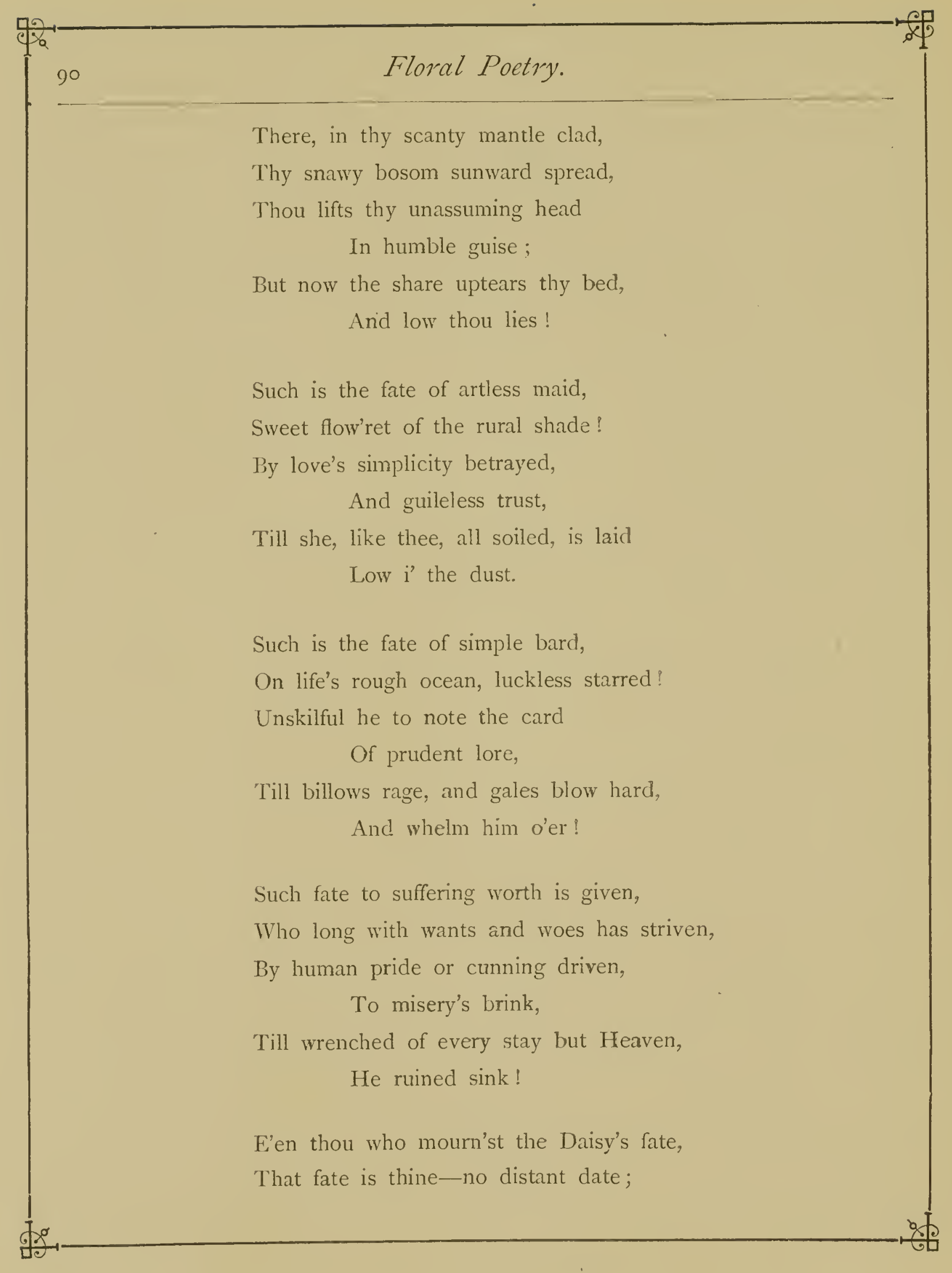




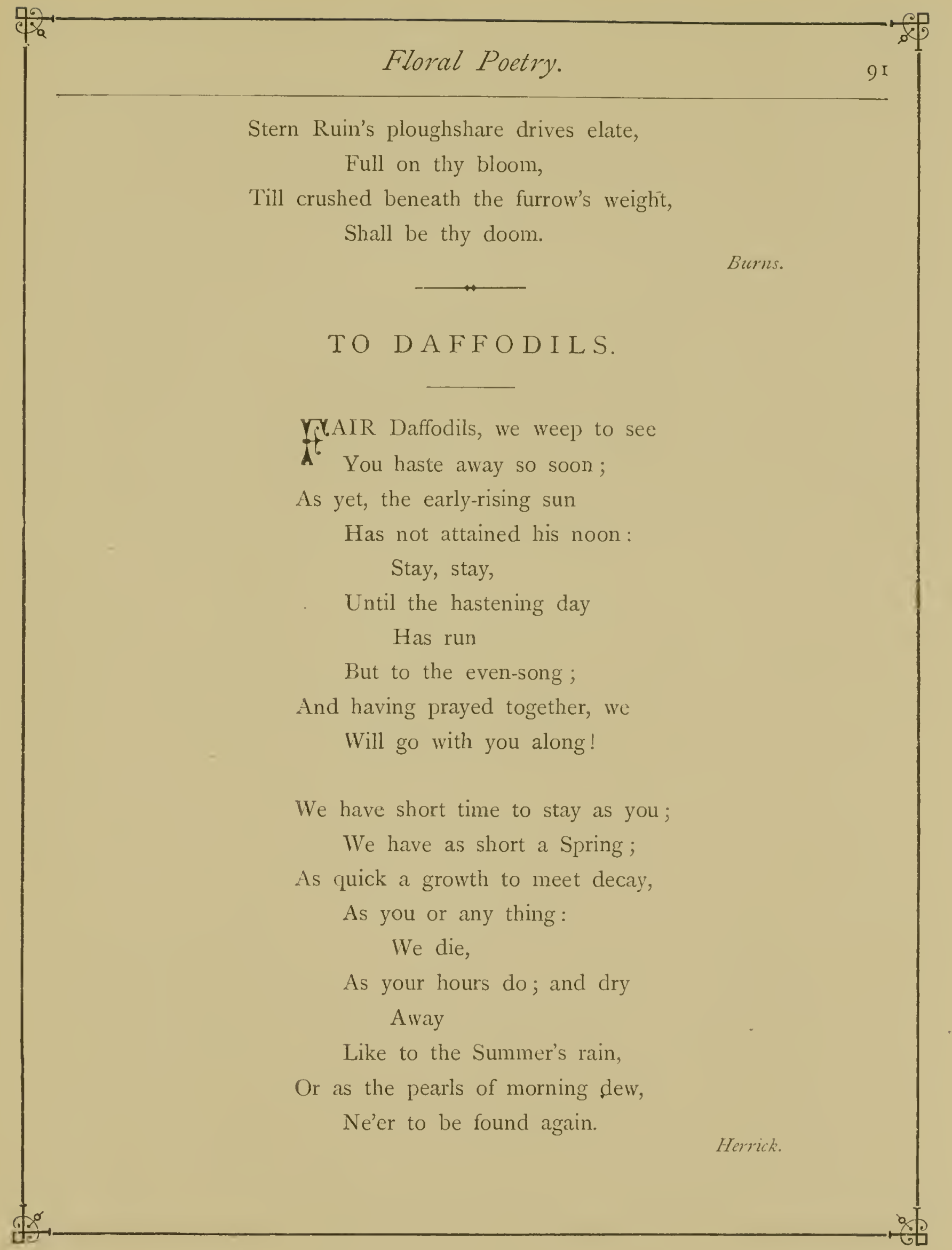




\section{THE DAISY IN INDIA.}

rruHRICE welcome, little English flower:

A. Thy mother country's white and red,

In Rose or Lily, till this hour

Never to me such beauty spread:

Transplanted from thy island bed,

A treasure in a grain of earth,

Strange as a spirit from the dead

Thy embryo sprang to birth.

Thrice welcome, little English flower!

Whose tribes beneath our native skies

Shut close their leaves while vapours lower;

But when the sun's gay beams arise,

With unabashed but modest eyes,

Follow his motion to the west,

Nor cease to gaze till daylight dies,

Then fold themselves to rest.

Thrice welcome, little English flower!

To this resplendent hemisphere,

Where Flora's giant offspring tower

In gorgeous liveries all the year;

Thou, only thou, art little here,

Like worth unfriended and unknown,

Yet to my British heart more dear

Than all the torrid zone. 


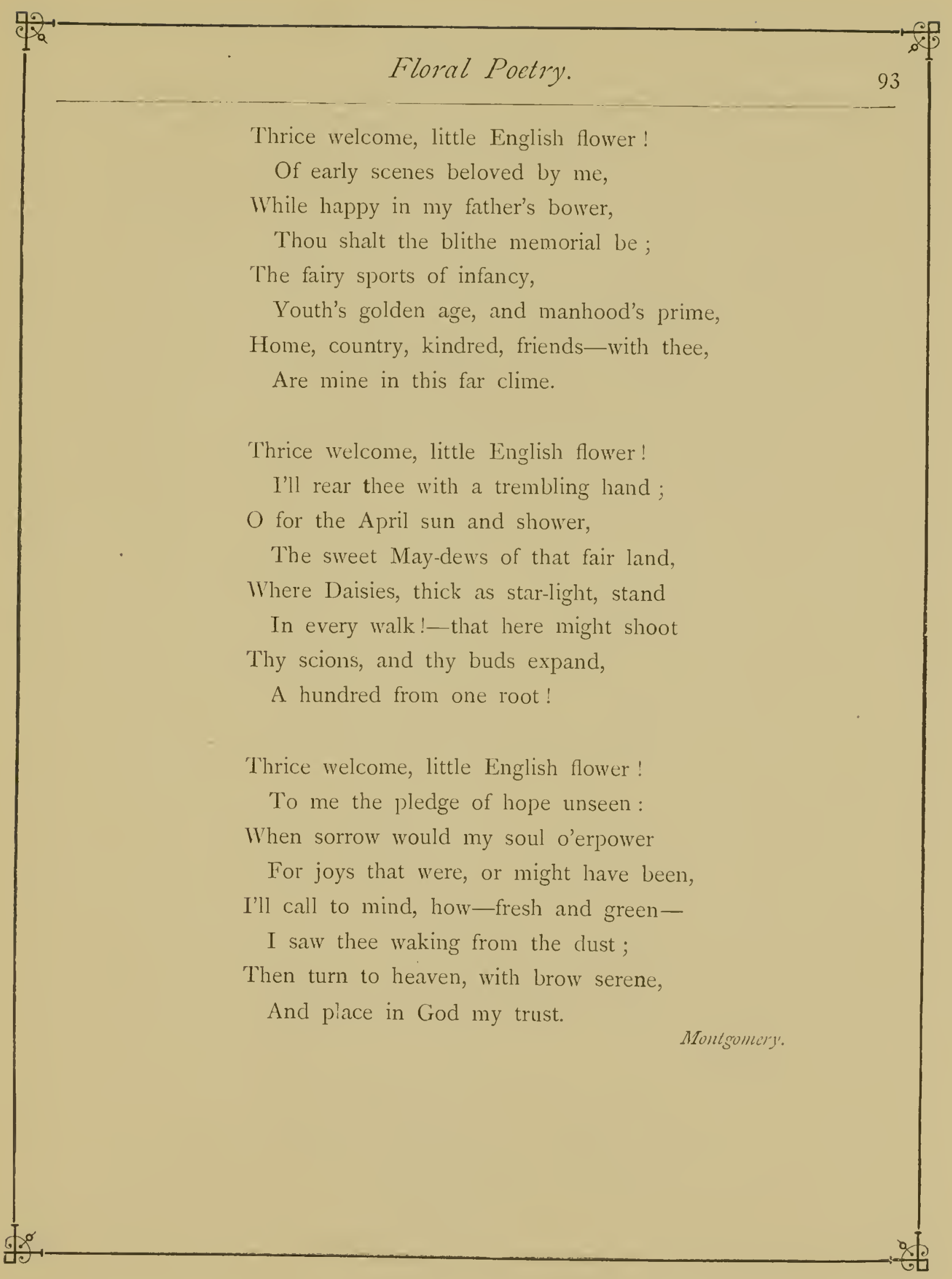




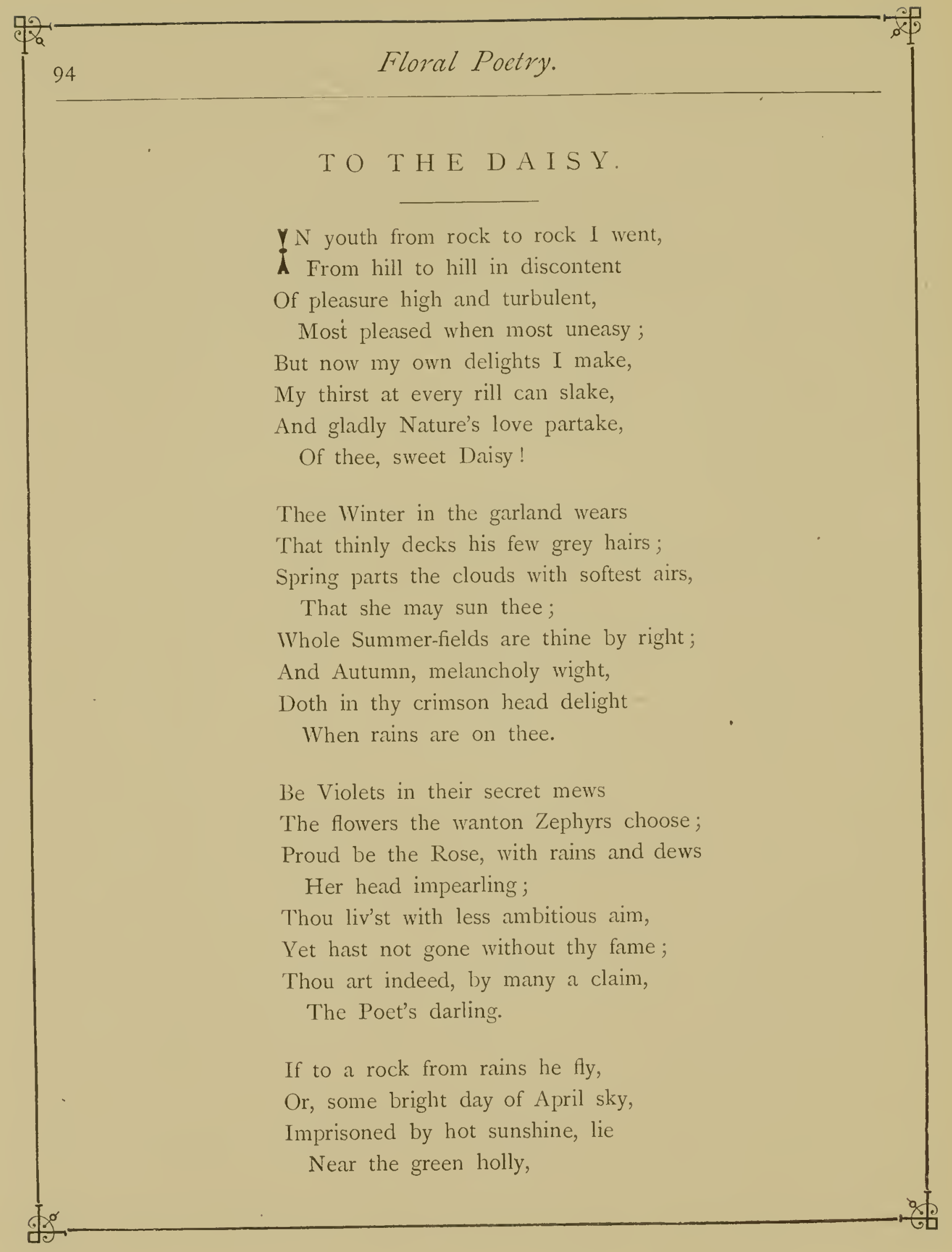




\section{Floral Poetry.}

And wearily at length should fare;

He needs but look about, and there

Thou art! - a friend at hand, to scare

His melancholy.

A hundred times, by rock or bower, Ere thus I have lain couched an hour, Have I derived from thy sweet power

Some apprehension;

Some steady love; some brief delight;

Some memory that had taken flight;

Some chime or fancy wrong or right,

Or stray invention.

If stately passions in me burn,

And one chance look to thee should turn,

I drink out of an humbler urn

A lowlier pleasure;

The homely sympathy that heeds

The common life, our nature breeds;

A wisdom fitted to the needs

Of hearts at leisure.

Fresh-smitten by the morning ray,

When thou art up, alert and gay,

Then, cheerful flower! my spirits play

With kindred gladness:

And when, at dusk, by dews opprest

Thou sink'st, the image of thy rest

Hath often eased my pensive breast

Of careful sadness.

And all day long I number yet,

All seasons through, another debt,

Which I, wherever thou are met,

To thee am owing; 


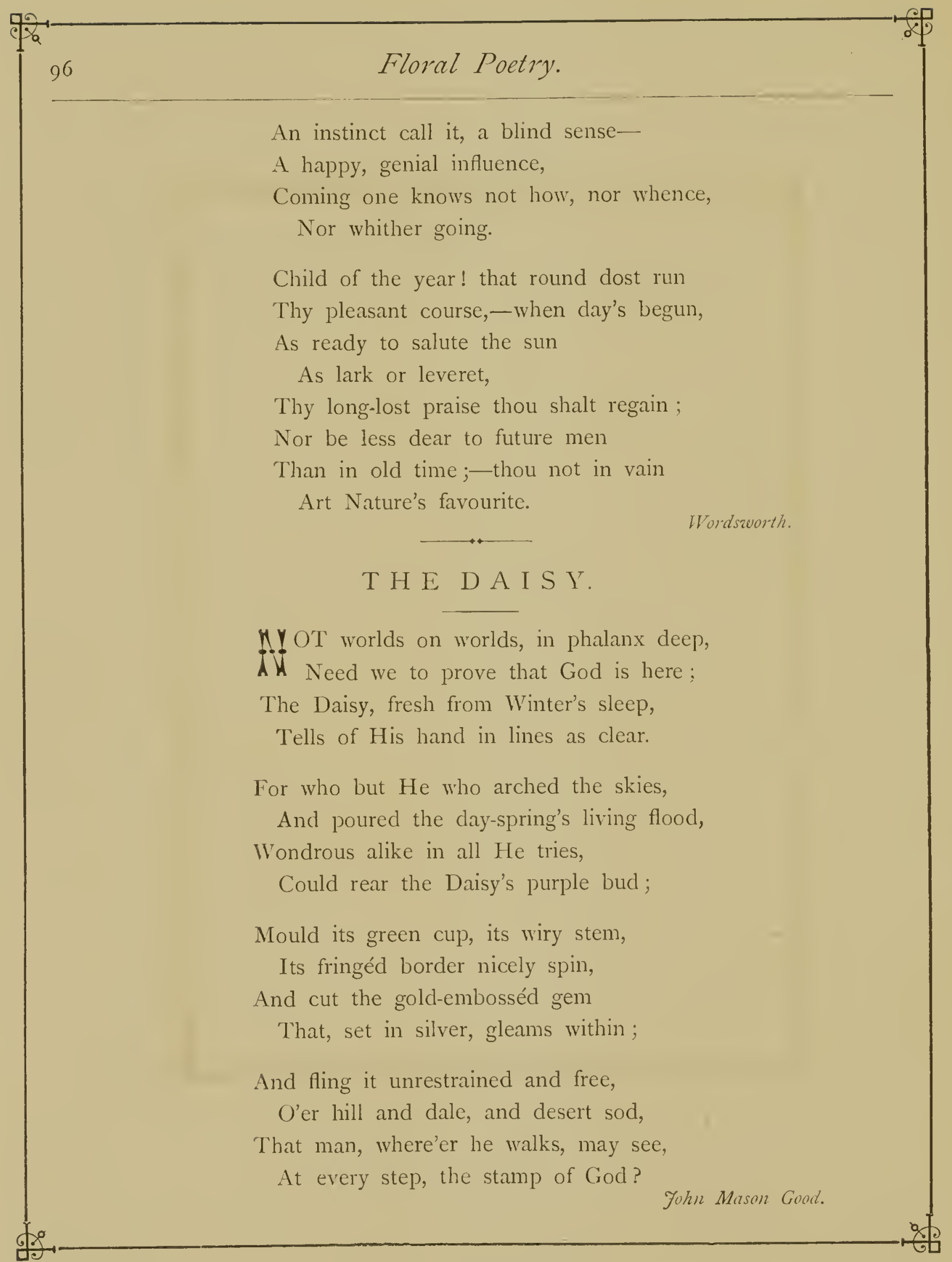




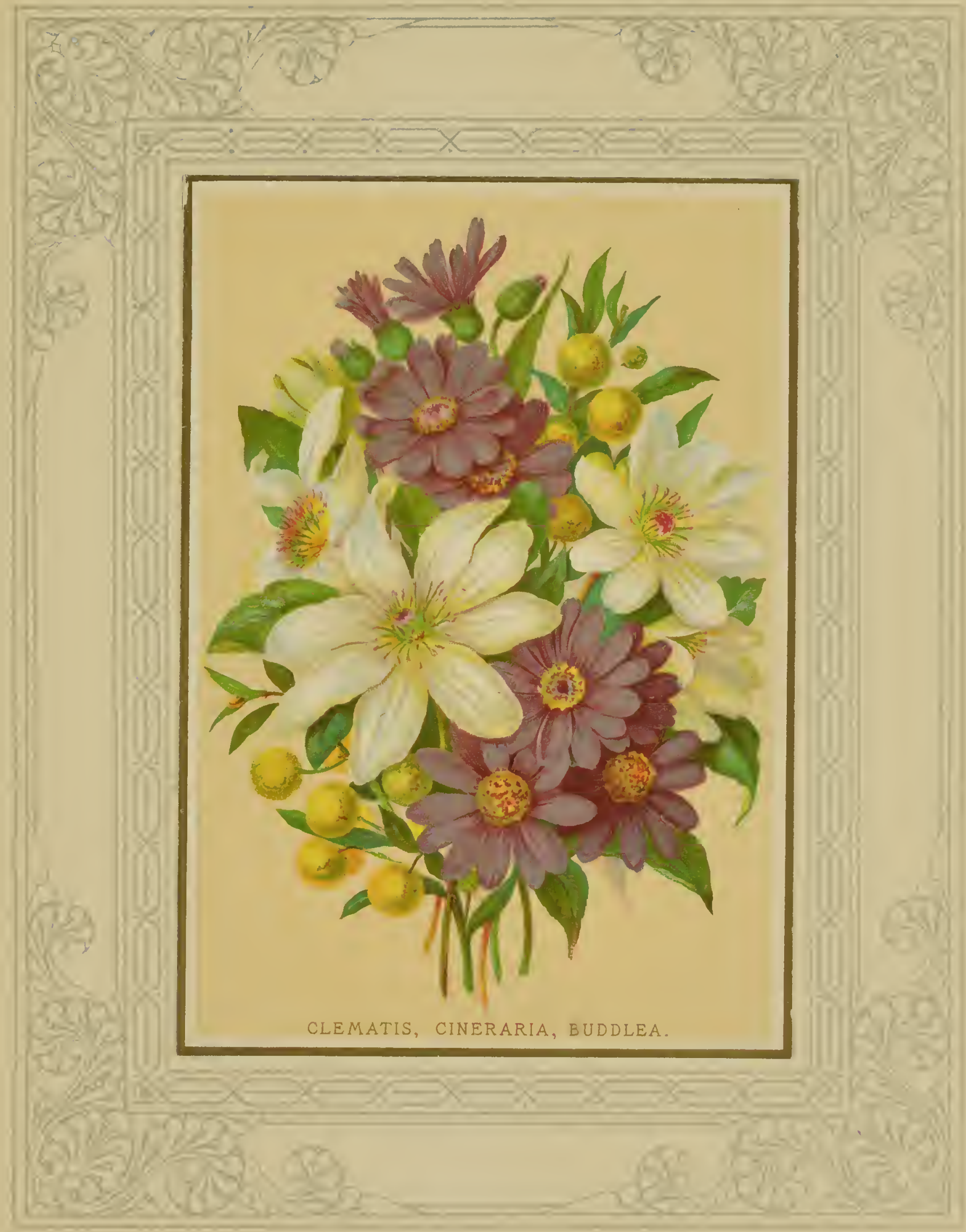





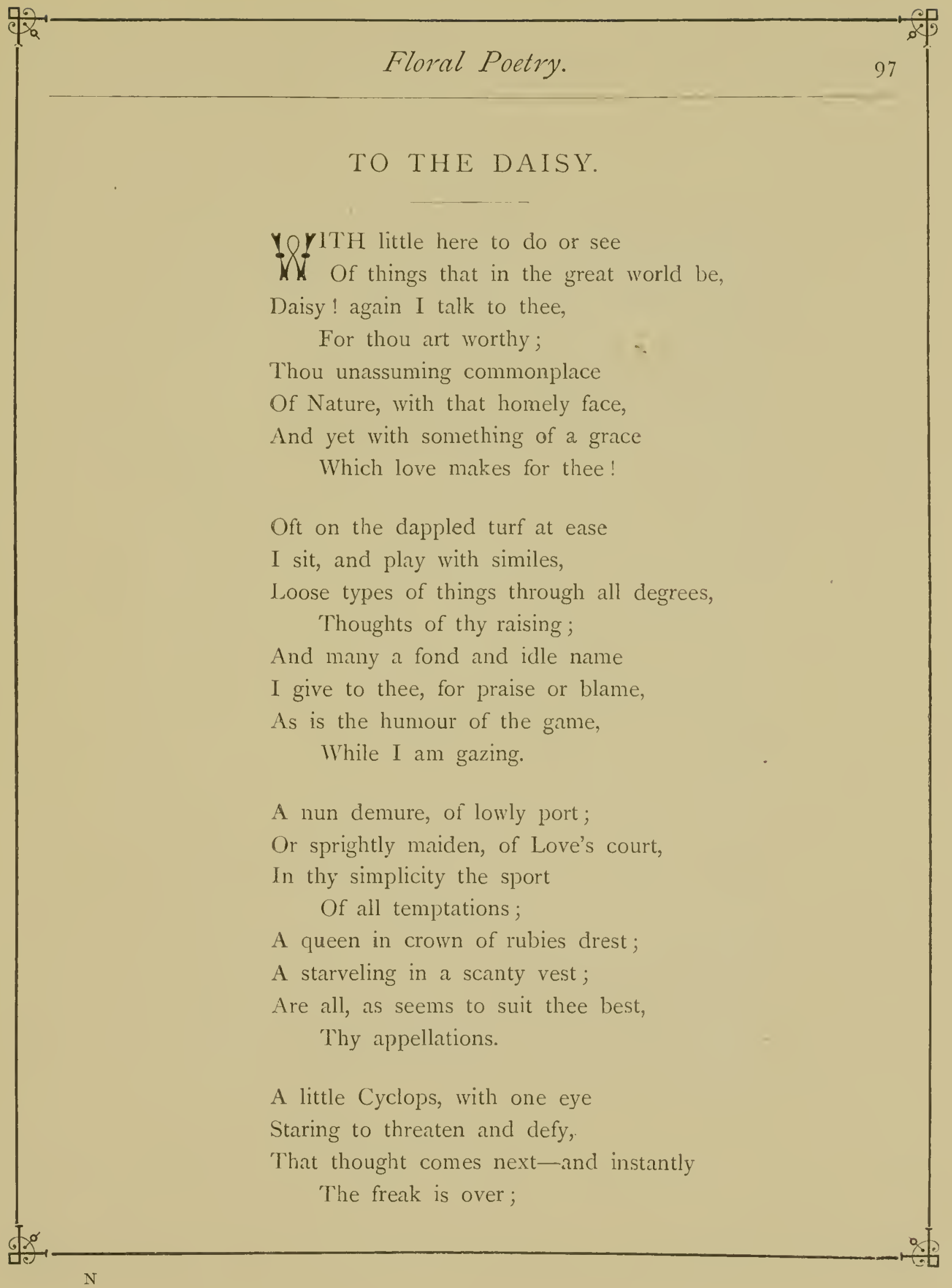




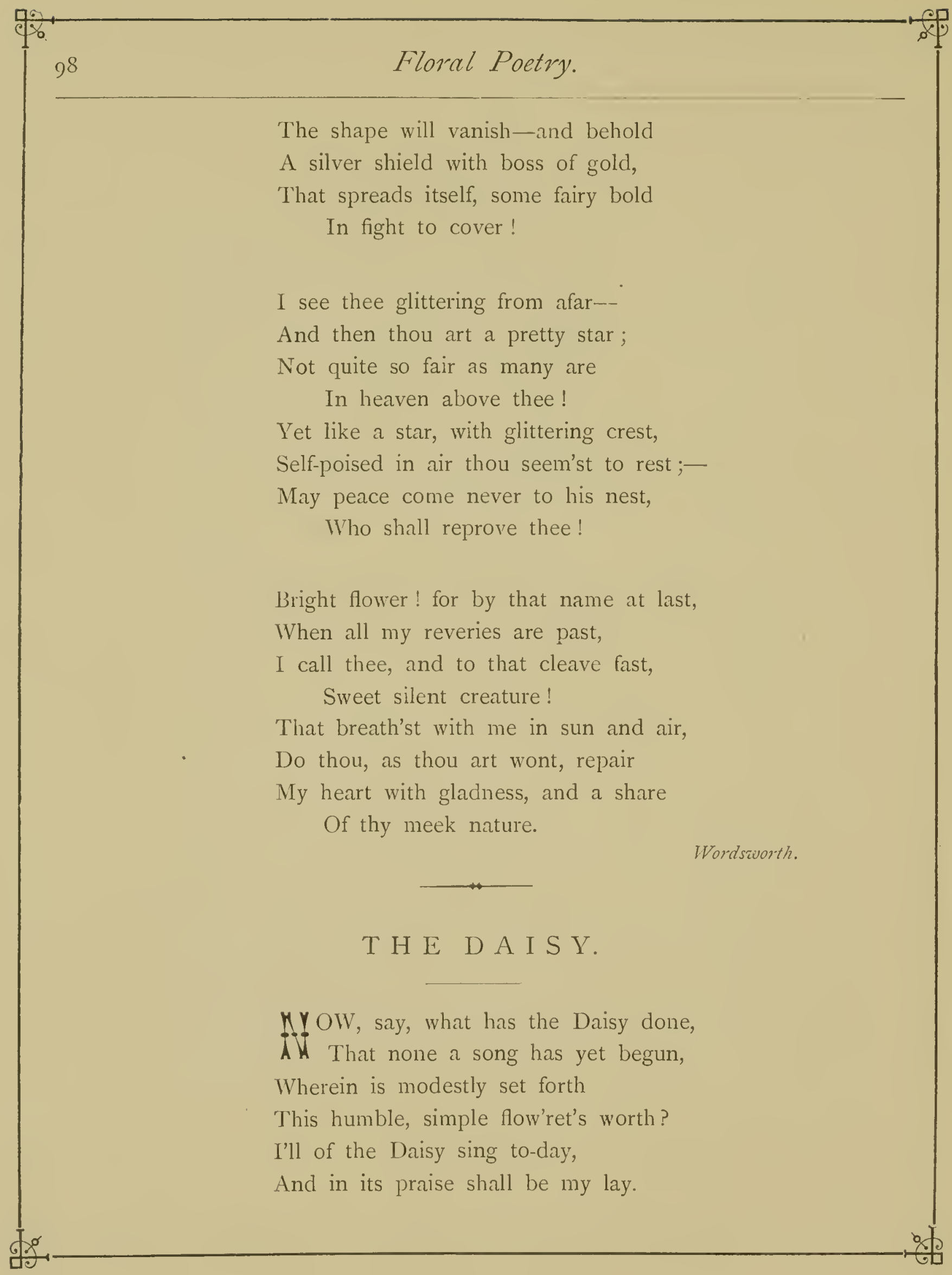




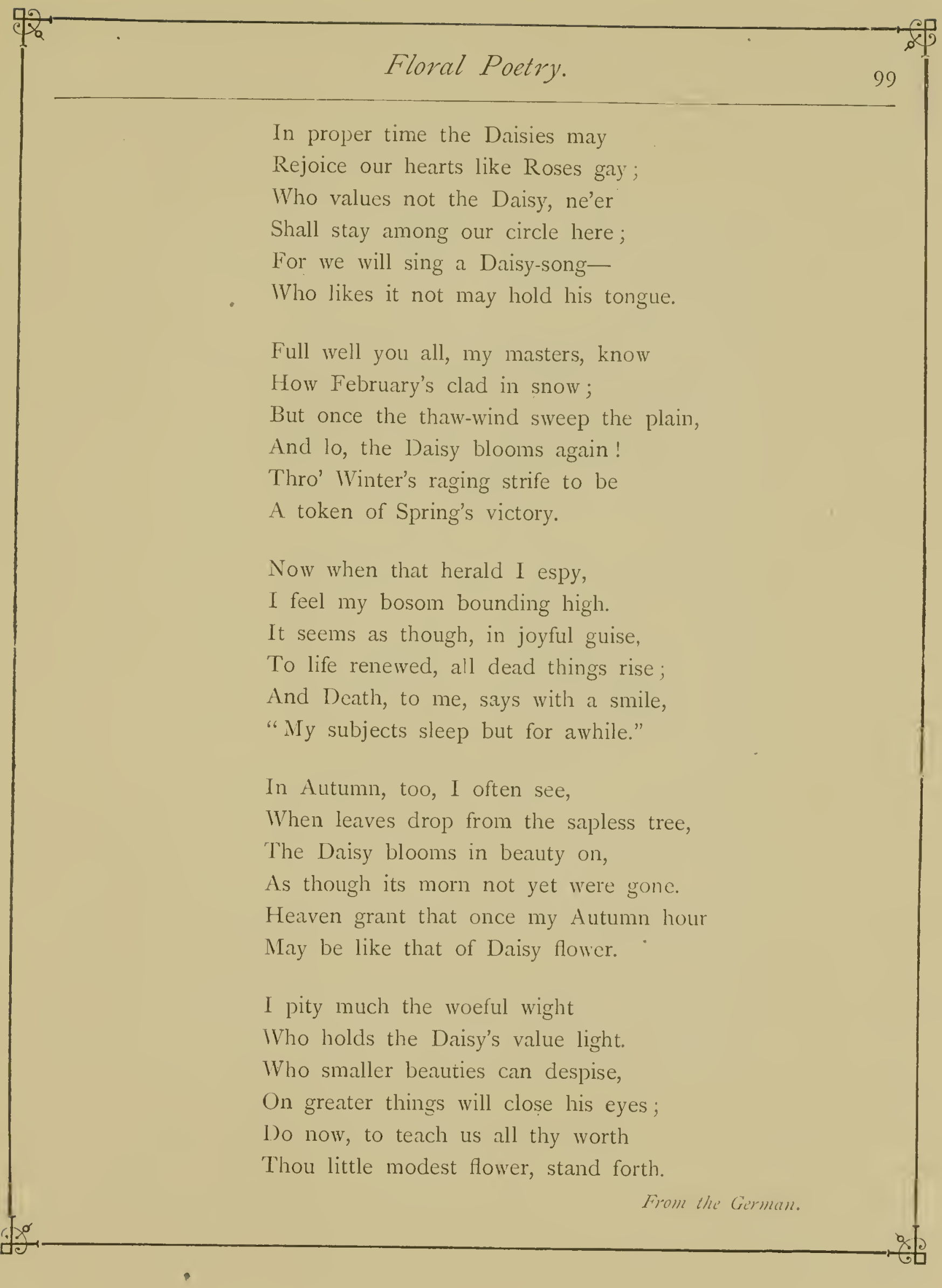




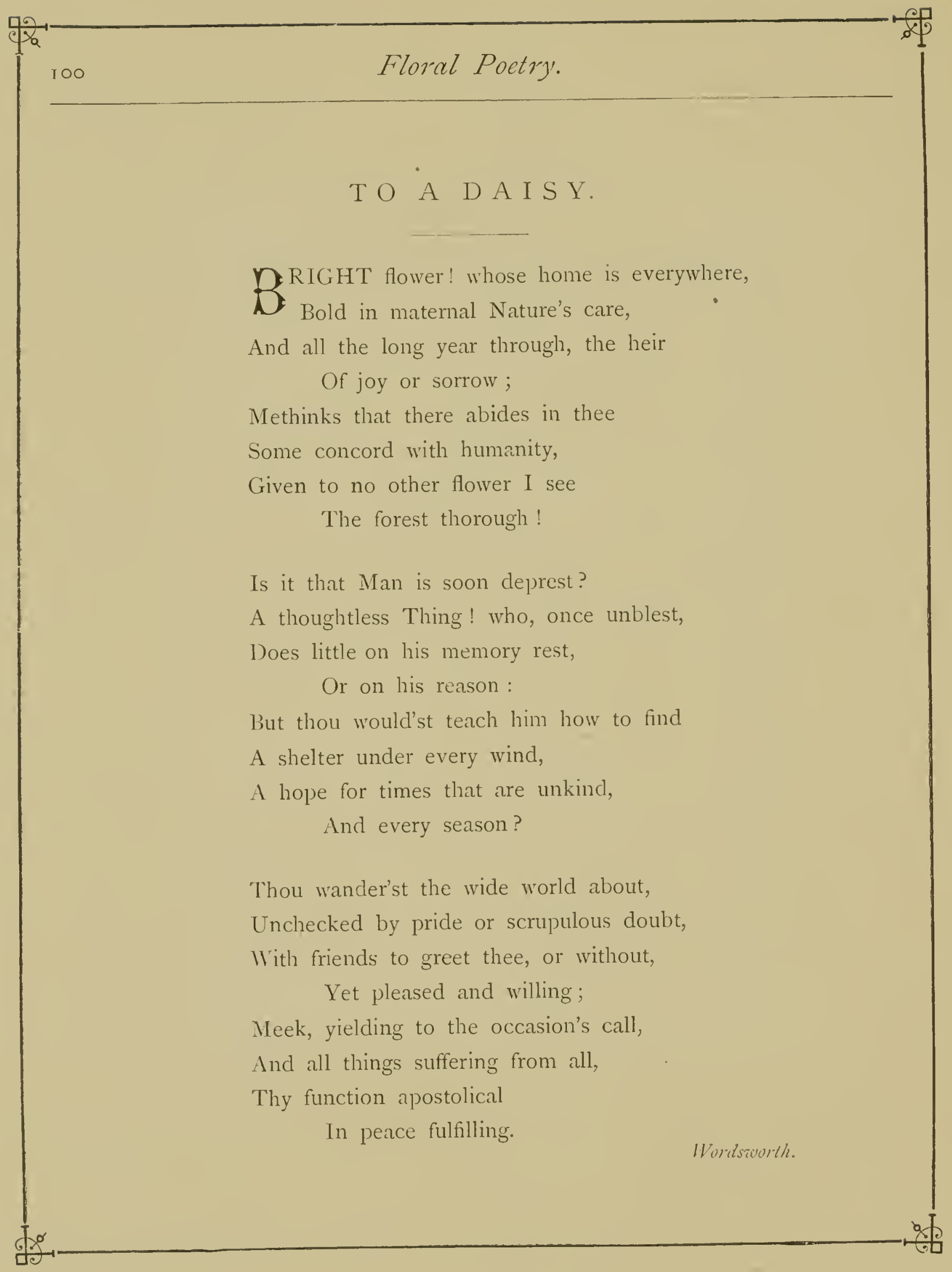




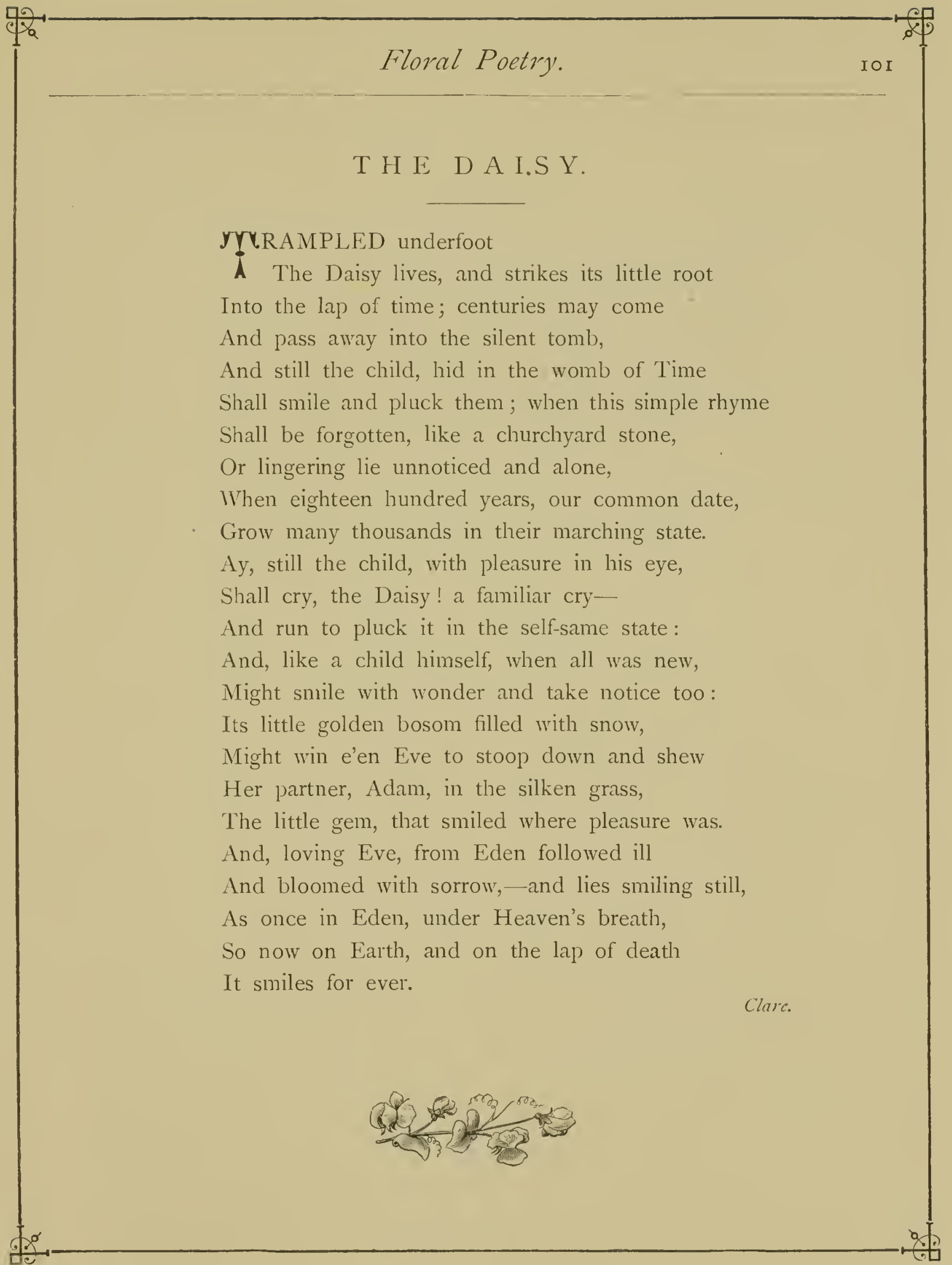




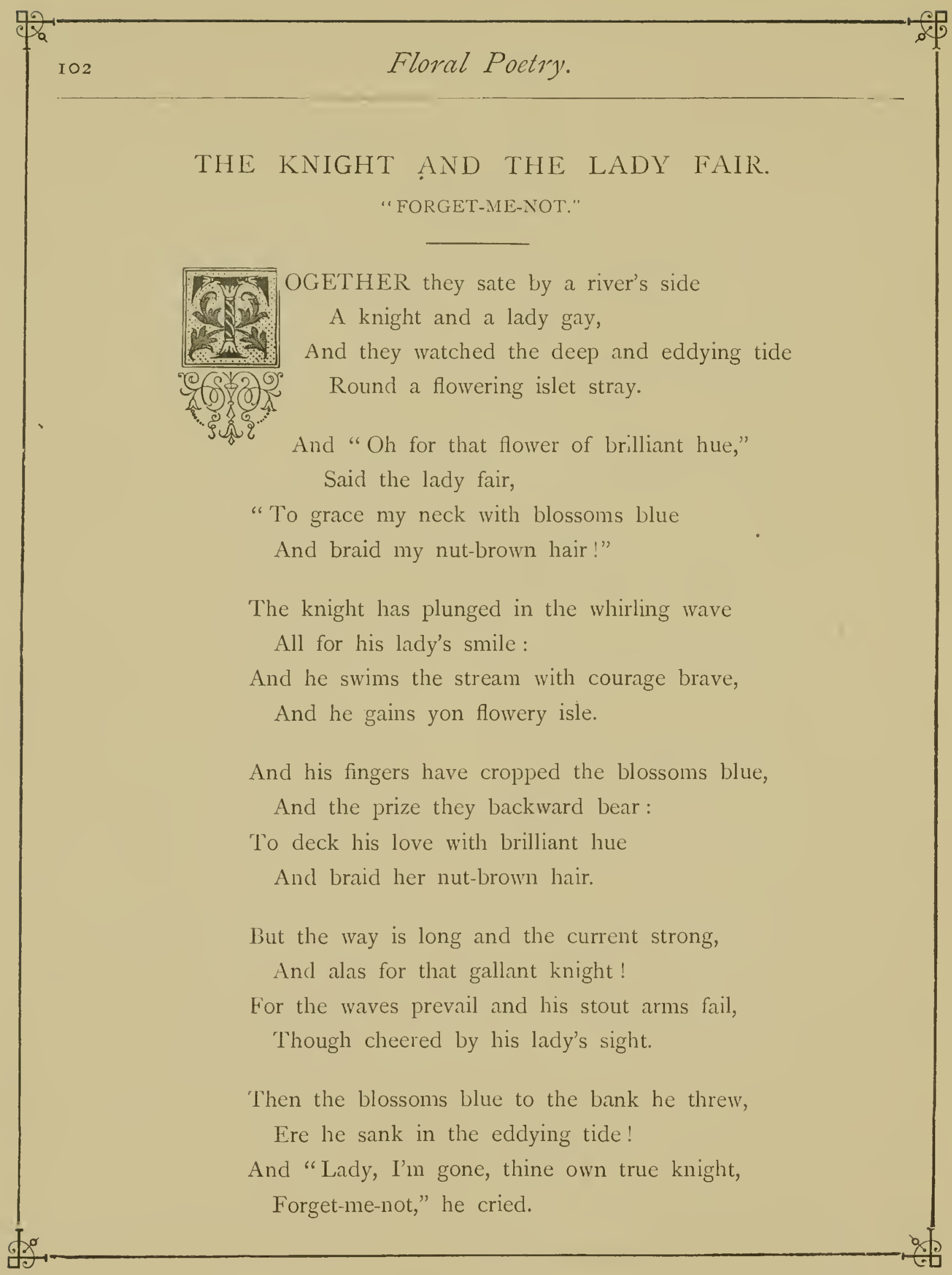




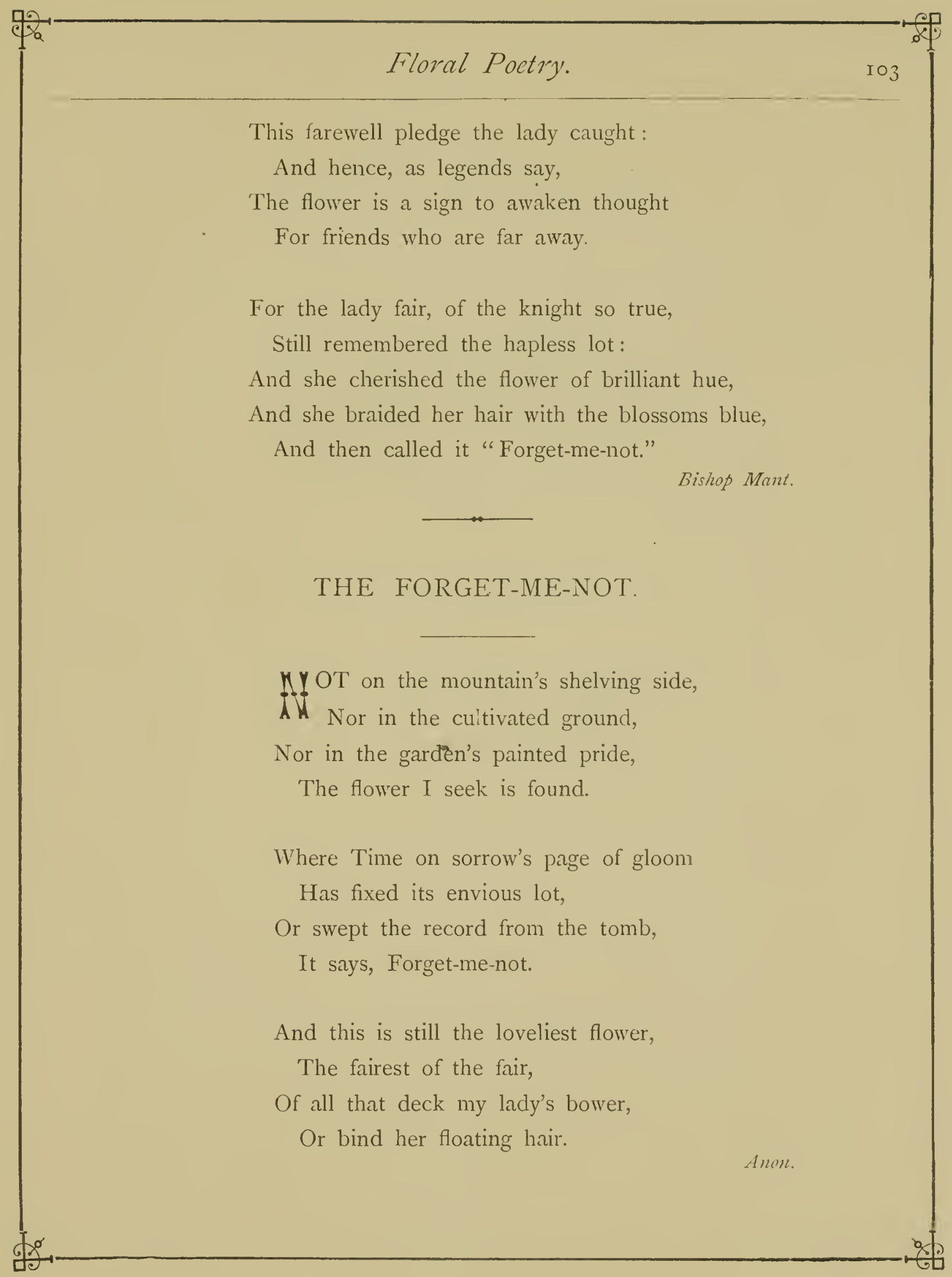




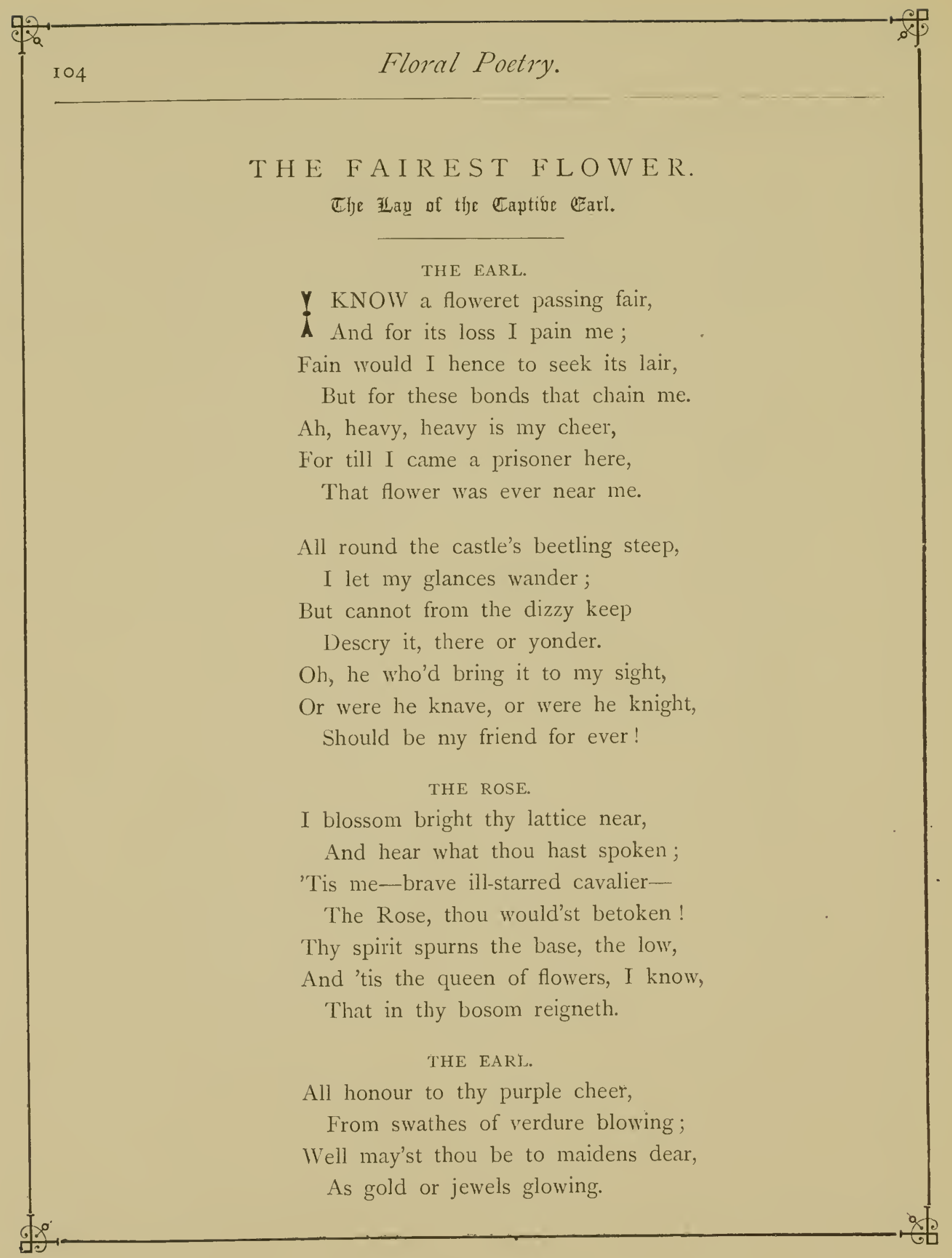




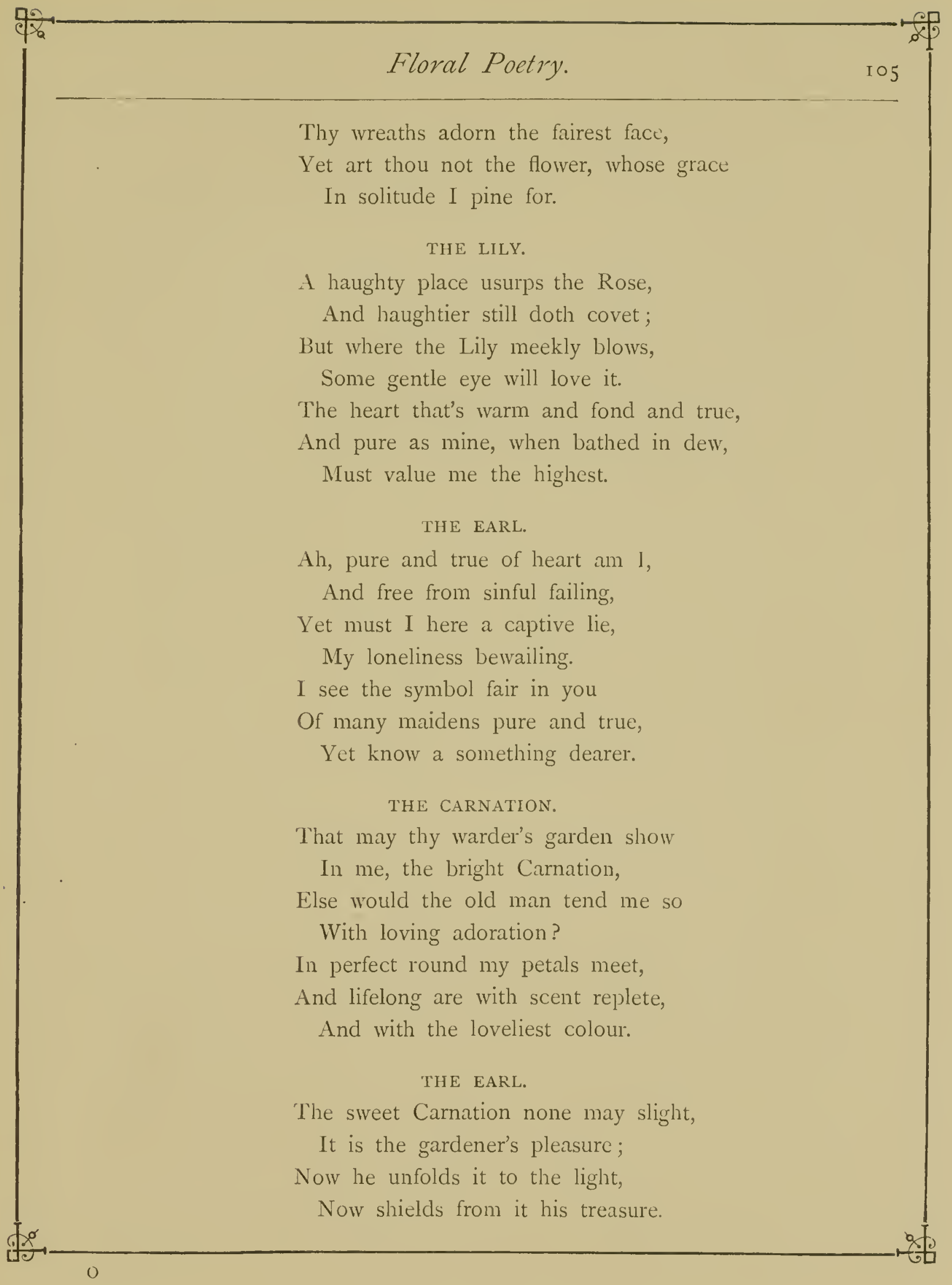


But no-the flower for which I pant,

No rare, no brilliant charms can vauunt,

'Tis ever meek and lowly.

THE VIOLET.

Concealed and drooping I retreat,

Nor willingly had spoken,

But now my silence, since 'tis meet,

It shall at length be broken.

If I be that which fills thy thought, How inust I grieve, that I may not

To thee waft all my odours!

THE EARL.

I love the Violet, indeed,

So modest in perfection,

So gently sweet-yet more I need,

To soothe my heart's dejection.

To thee alone the truth I'll speak,

Not on this rock, so bare and bleak,

Is to be found my darling.

Earth's truest wife, in yonder glen,

Is wandering by the river;

Till I, her lord, am free again,

She'll sigh and weep for ever.

When a blue floweret by that spot

She plucks, and says-FORGET-NE-NOT,

Here in my cell I feel it. 


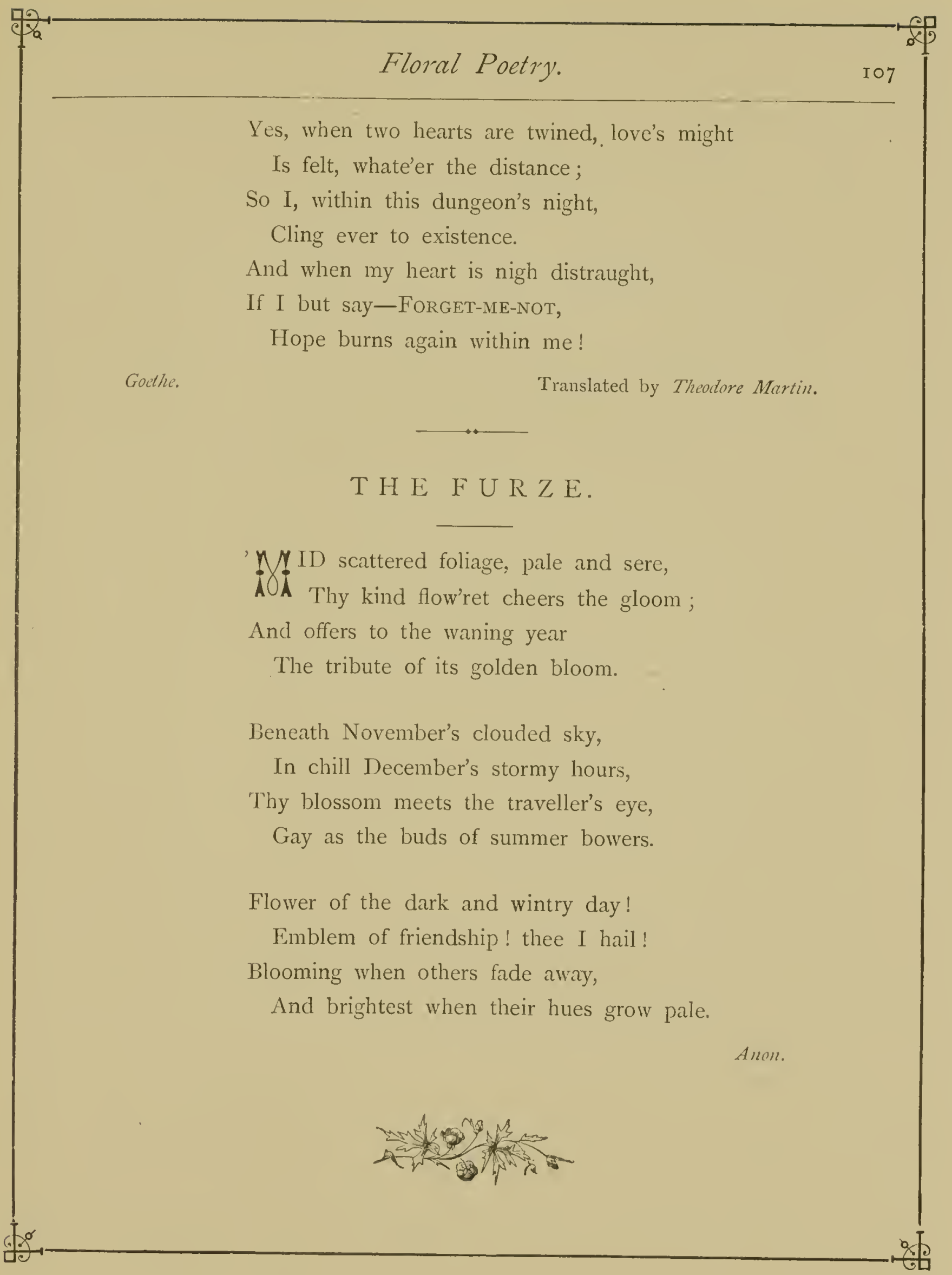




\section{THE SCARLET GERANIUM.}

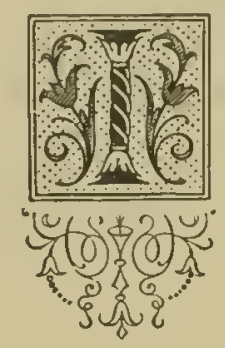

WILL not sing the mossy Rose, The Jasmine sweet, or Lily fair, The tints the rich Carnation shows, The Stock's sweet scent that fills the air.

Full many a bard has sung their praise In metres smooth, and polished line;

A simple flower and humbler lays

May best befit a pen like mine.

There is a small but lovely flower,

With crimson star and calyx brown, On pathway side beneath the bower, By Nature's hand profusely strown.

Inquire you when this flow'ret springs? When Nature wakes to mirth and love, When all her fragrance Summer flings, When latest Autumn chills the grove.

Like the sweet bird whose name it bears,

'Midst falling leaves and fading flowers, The passing traveller it cheers,

In shortened days and darksome hours. 


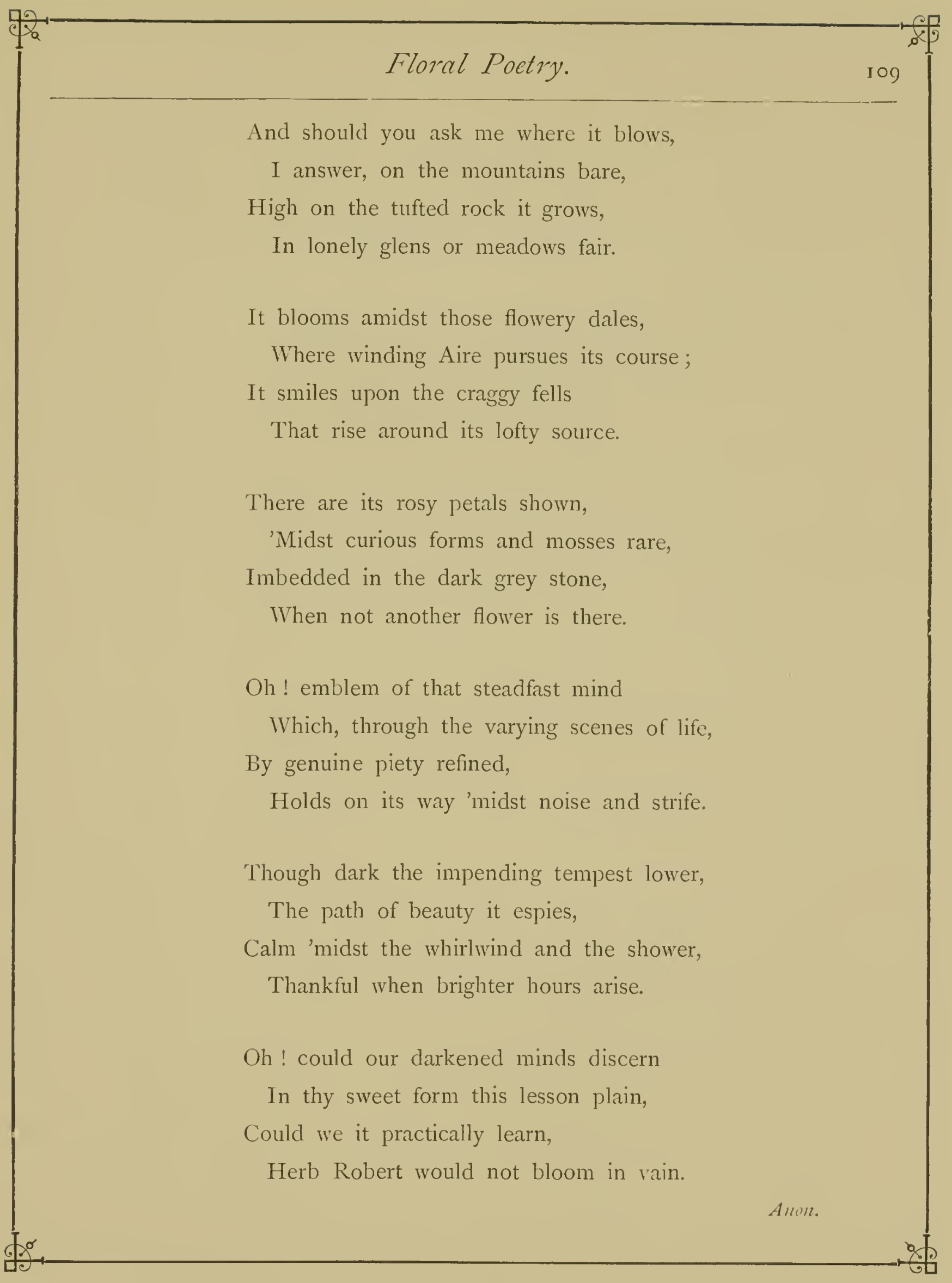




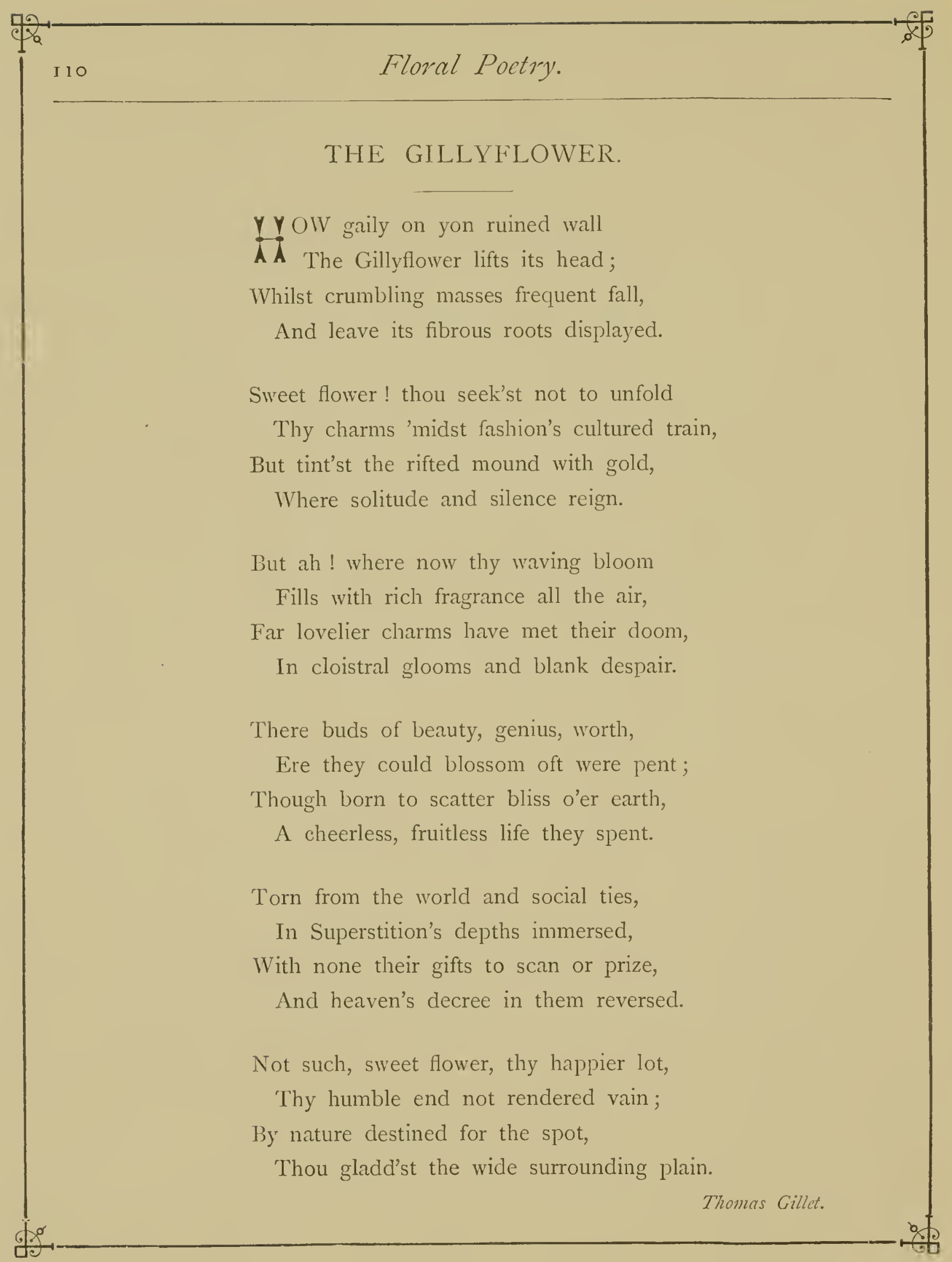




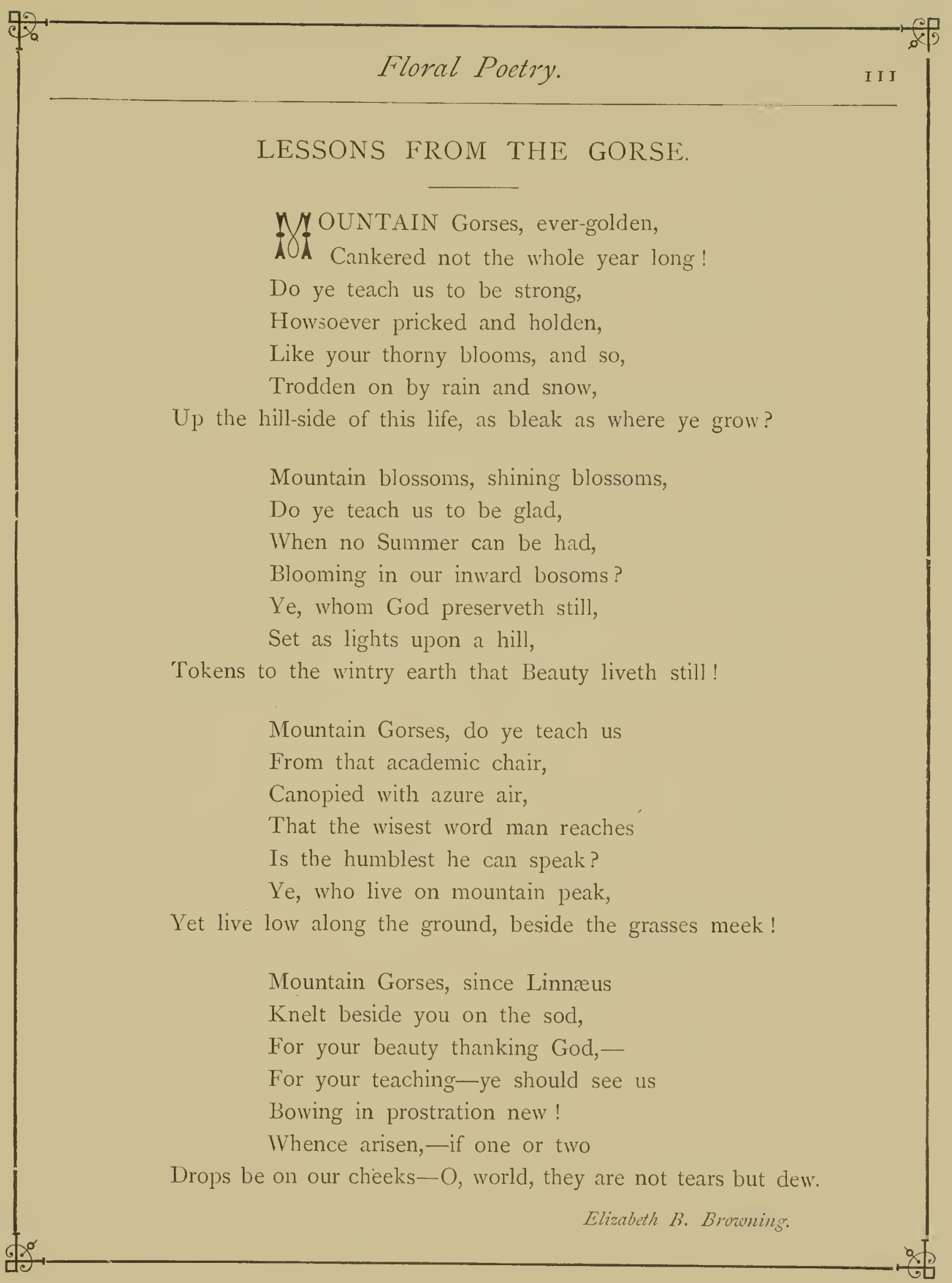




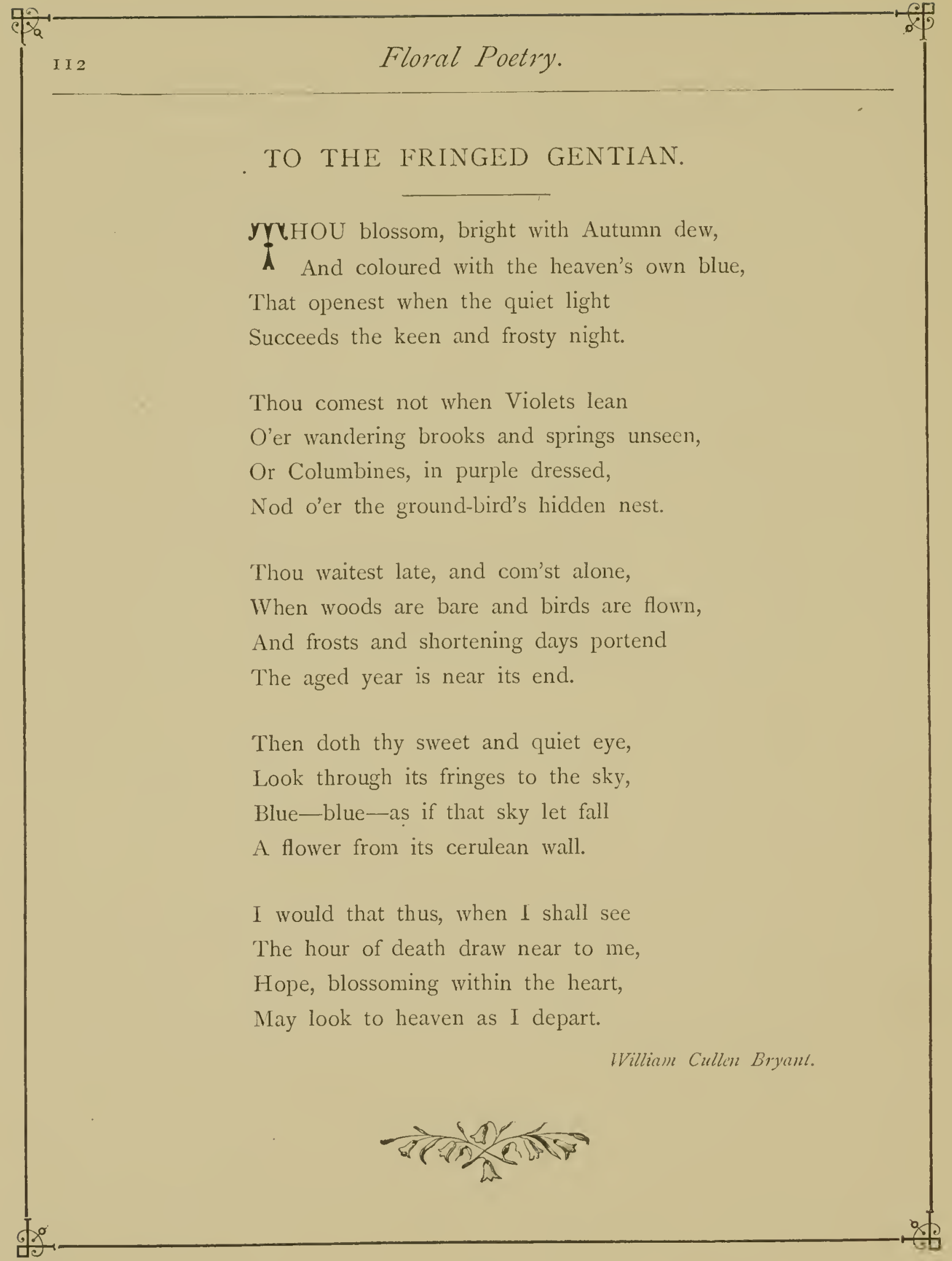




\section{THE HAWTHORN TREE-THE GLORY OF MAY.}

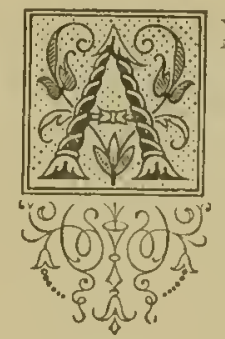

MONG the many buds proclaiming May, (Decking the fields in holy-day's array, Striving who shall surpass in bravery,)

Mark the fair blooming of the Hawthorn tree;

Who, finely clothèd in a robe of white,

Feeds full the wanton eye with May's delight.

Yet, for the bravery that she is in,

Doth neither handle card nor wheel to spin,

Nor changeth robes but twice, is never seen

In other colours than in white or green.

Learn then content, young shepherd, from this tree,

Whose greatest wealth is Nature's livery;

And richest ingots never toil to find,

Nor care for poverty, but of the mind.

THE H A R E B E L L.

"YOR me,"-she stopped, and, looking round,

ג. Plucked a blue Harebell from the ground,--

"For me, whose memory scarce conveys

An image of more splendid days,

This little flower that loves the lea,

May well my simple emblem be;

It drinks heaven's dew, blithe as the Rose

That in the king's own garden grows;

And when I place it in my hair,

Allan, a bard is bound to swear

He ne'er saw coronet so fair." 
IN Spring's green lap there blooms a flower,

$\boldsymbol{\lambda}$ Whose cup imbibes each vernal shower;

That sips fresh nature's balmy dew,

Clad in her sweetest, purest blue;

Yet shuns the ruddy eye of morning,

The shaggy wood's brown shades adorning.

Simple flow'ret! child of May!

Though hid from the broad gaze of day,

Doomed in the shade thy sweets to shed,

Unnoticed droops thy languid head;

Still Nature's darling thou'lt remain,

She feeds thee with her softest rain;

Fills each swcet bud with honeyed tears,

With genial gales thy bosom cheers.

Ah, then unfold thy simple charms,

In yon deep thicket's circling arms,

Far from the fierce and sultry glare,

No heedless hand shall harm thee there;

Still, then, avoid the gaudy scene,

The flaunting sun, th' embroidered green,

And bloom and fade, with chaste reserve, unseen.

Caroline Symmons. 
THE H A Z E L.

YHENE'ER I see soft hazel eyes

And nut-brown curls,

I think of those bright days I spent

Among the Limerick girls;

When up through Cratla woods I went,

Nutting with thee;

And we plucked the glossy clustering fruit

From many a bending tree.

Beneath the hazel boughs we sat,

Thou, love, and I,

And the gathered nuts lay in thy lap,

Beneath thy downcast eye:

But little we thought of the store we'd won,

I, love, or thou;

For our hearts were full, and we dare not own

The love that's spoken now.

Oh, there's wars for willing hearts in Spain,

And high Germanie!

And I'll come back, ere long, again,

With knightly fame and fee:

And I'll come back, if I ever come back,

Faithful to thee,

That sat with thy white lap full of nuts

Beneath the Hazel tree. 


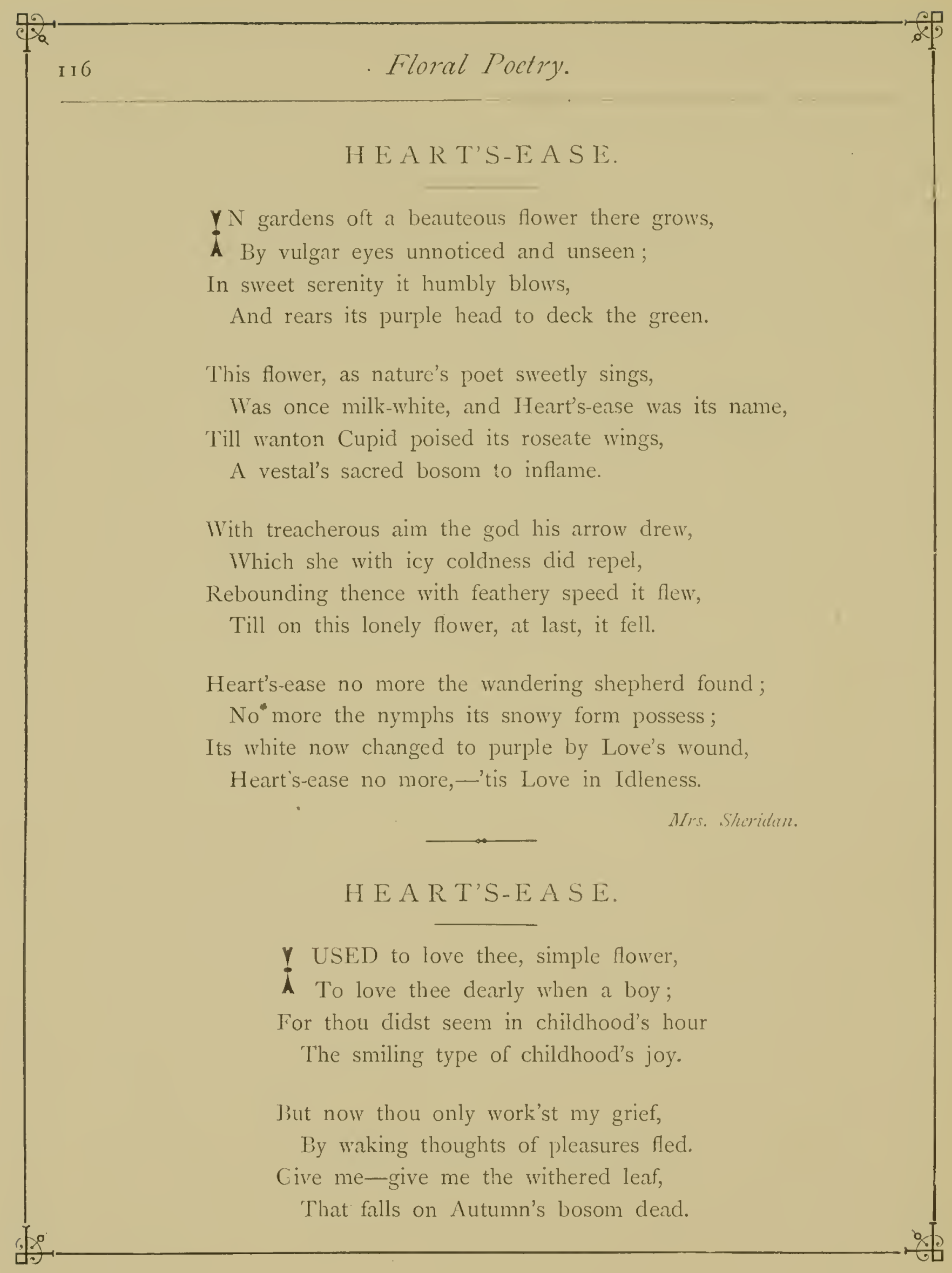




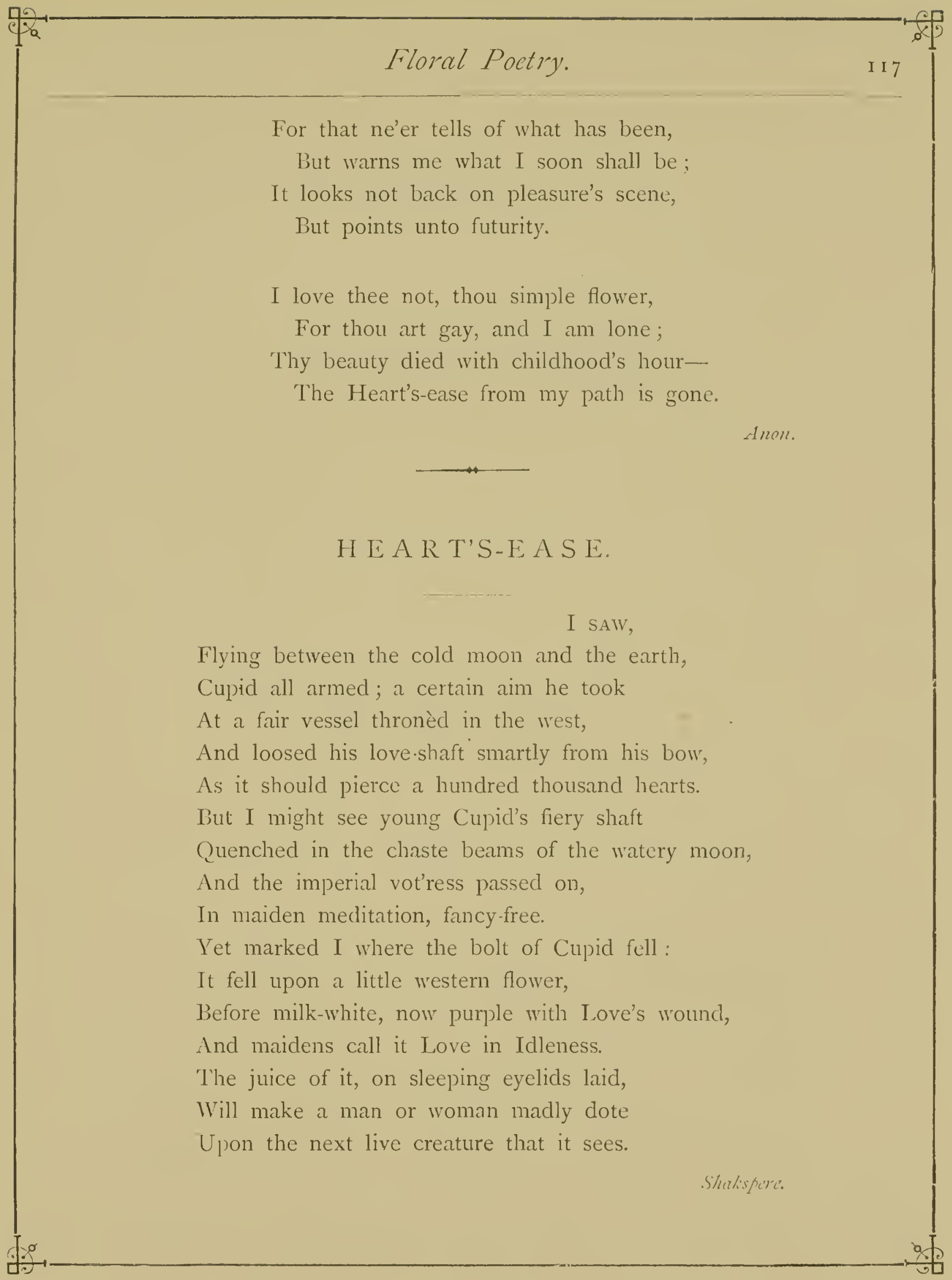




\section{THE HOLLY TREE.}

READER! hast thou ever stood to see
The Holly tree?

The eye that contemplates it well perceives

Its glossy leaves,

Ordered by an Intelligence so wise

As might confound the atheist's sophistries.

Below a circling fence its leaves are seen,

Wrinkled and keen;

No grazing cattle through their prickly round

Can reach to wound;

But, as they grow where nothing is to fear,

Smooth and unarmed the pointless leaves appear.

I love to view these things with curious eyes,

And moralise;

And in this wisdom of the Holly tree

Can emblems see,

Wherewith, perchance, to make a pleasant rhyme;

One which may profit in the after-time.

'Thus, though abroad, perchance, I might appear

Harsh and austere;

To those who on my leisure would intrude,

Reserved and rude;

Gentle at home amid my friends I'd be,

Like the high leaves upon the Holly tree.

And should my youth, as youth is apt, I know,

Some harshness show,

All vain asperities I, day by day,

Would wear away,

Till the smooth temper of my age should be

Like the high leaves upon the Holly tree. 


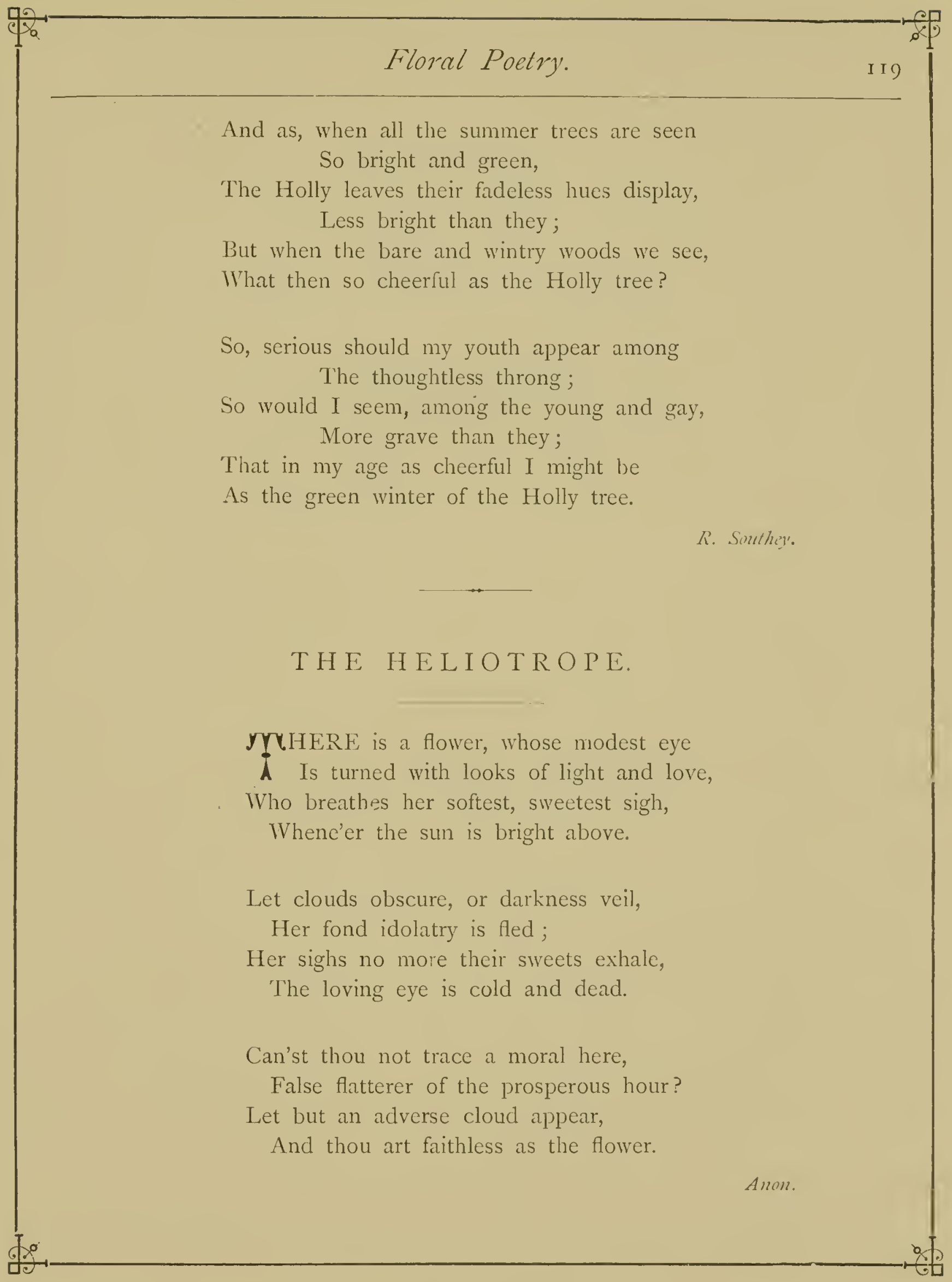




\section{TO THE HEPATICA.}

CWEET gem of Flora's earliest bower !

2 Uprear thy blushing head;

Though wintry skies upon thee lower,

And snows around are spread;

Still let thy lovely petals glow,

Arrayed in all their charms,

And to distrustful mortals show,

Life buds in death's cold arms.

Sweet gem! thy blush is like the glow

By convalescence dealt,

That paints the cheek, and gilds the brow,

Where sickness long had dwelt;

Or like the radiant quickening smile,

By kind affection given,

That soothes the heart, despair and guile

Had sunk and almost riven.

Invite thy sisters of the plain,

Each vernal fragrant sweet;

Till with gay tribes of every stain,

The garden smiles replete:

And let thy lovely petals glow,

Still clad in all their charms;

And to distrustful mortals show

I ife buds in death's cold arms.

Thomas Gillet. 


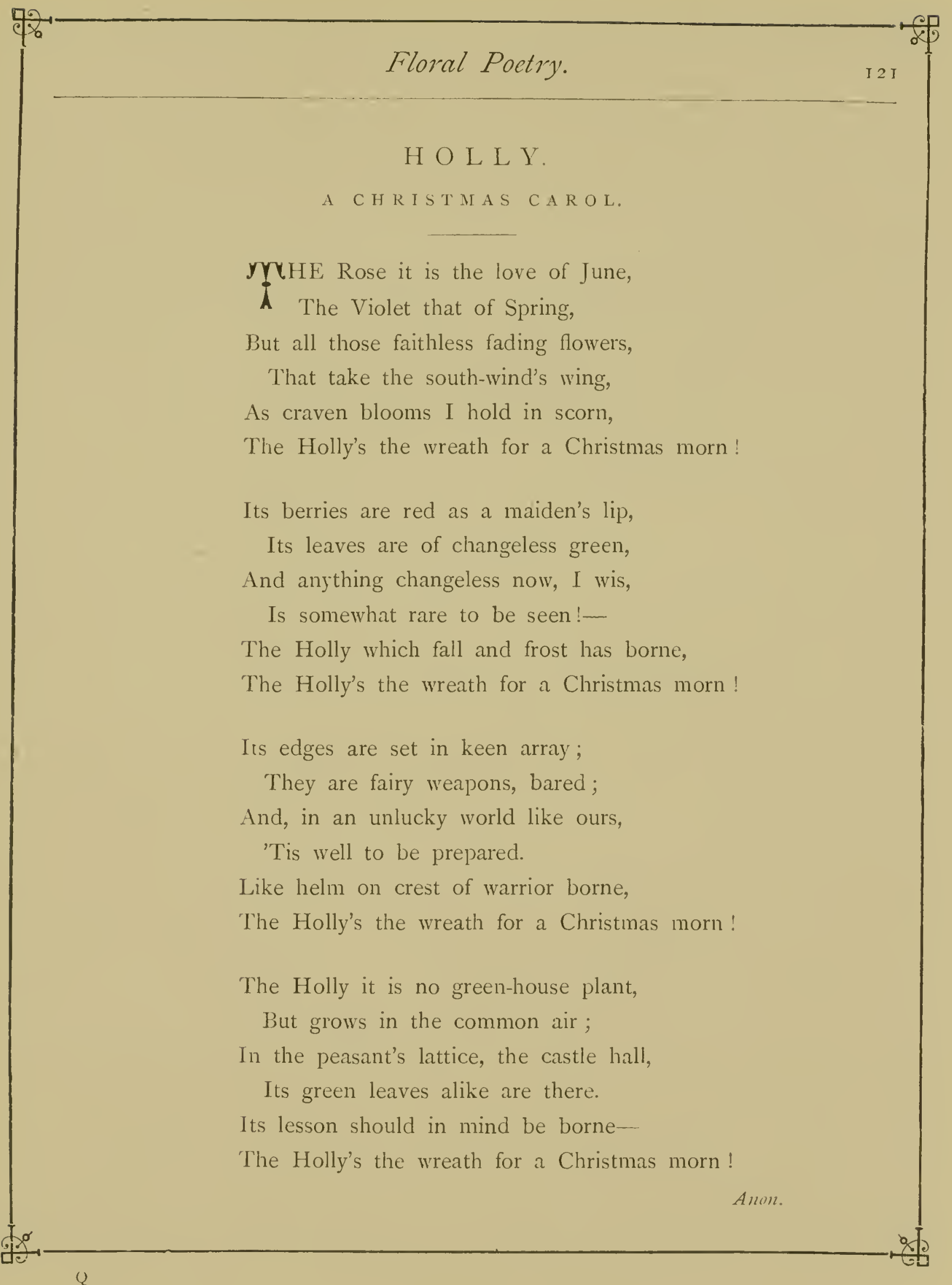




\section{HOLL Y A N I V Y. \\ PART 1.}

Y OLLY and Ivy made a great party,

A Who should have the mastery

In lands where they go.

Then spake the Holly, "I am fierce and jolly,

I will have the mastery

in lands where we go."

Then spake Ivy, "I am loud and proud,

And I will have the mastery

In lands where we go."

Then spake Holly, and bent him duwn on his knee,

"I pray thee, gentle Iry,

lissay me no villany

In lands where we go."

PART II.-THE REPLY.

Nay, Ivy, nay, it shall not be, I wis,

Let Holly have the mastery as the manner is.

Holly standeth in the hall fair to behold,

Ivy standeth without the door; she is full sore a-cold.

$$
\text { Nay, Ivy, nay, \&c. }
$$

Holly and his merry men, they dance now and they sing;

Ivy and her maidens, they weep, and their hands wring.

$$
\text { Nay, Ivy, nay, Stc. }
$$

Holly he hath berries as red as any rose,

The foresters, the hunters, keep them from the does.

$$
\text { Nay, Ivy, nay, \&c. }
$$




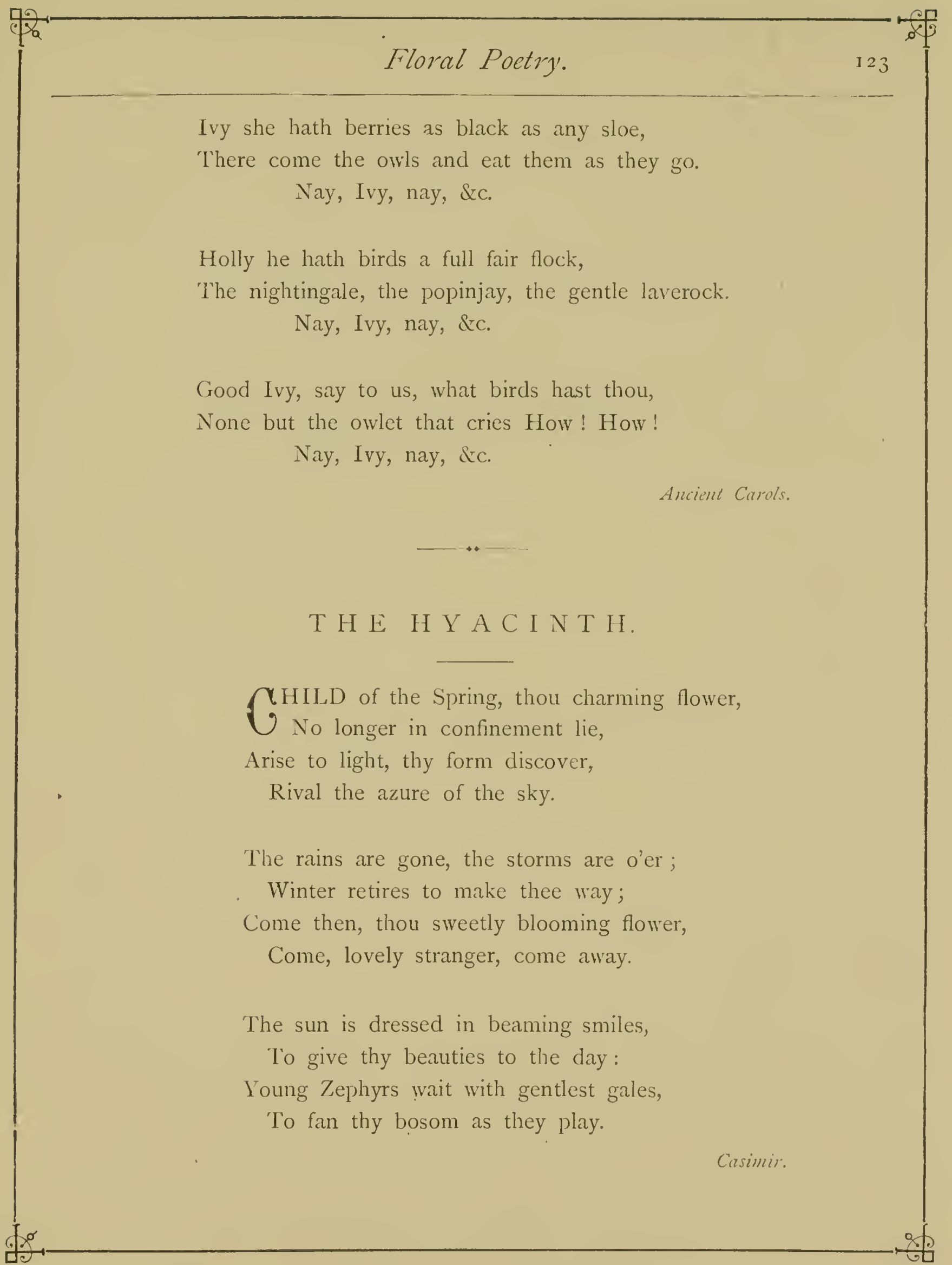




\section{THE HONEYSUCKLE.}

CEE the Honeysuckle twine

2. Round this casement:-'tis a shrine

Where the heart doth incense give,

And the pure affections live

In the mother's gentle breast

By her smiling infant pressed.

Blessèd shrine! dear, blissful home!

Source whence happiness doth come!

Round by the cheerful hearth we meet

All things beauteous - all things sweet-

Every solace of man's life,

Mother-daughter-sister-wife.

England, isle of free and brave,

Circled by the Atlantic wave!

Though we seek the fairest land

That the south wind ever fanned,

Yet we cannot hope to see

Homes so holy as in thee.

As the tortoise turns its head

Towards its native ocean-bed,

Howsoever far it be

From its own belovèd sea,

Thus, dear Albion, evermore

Do we turn to seek thy shore!

Countess of Blessington. 


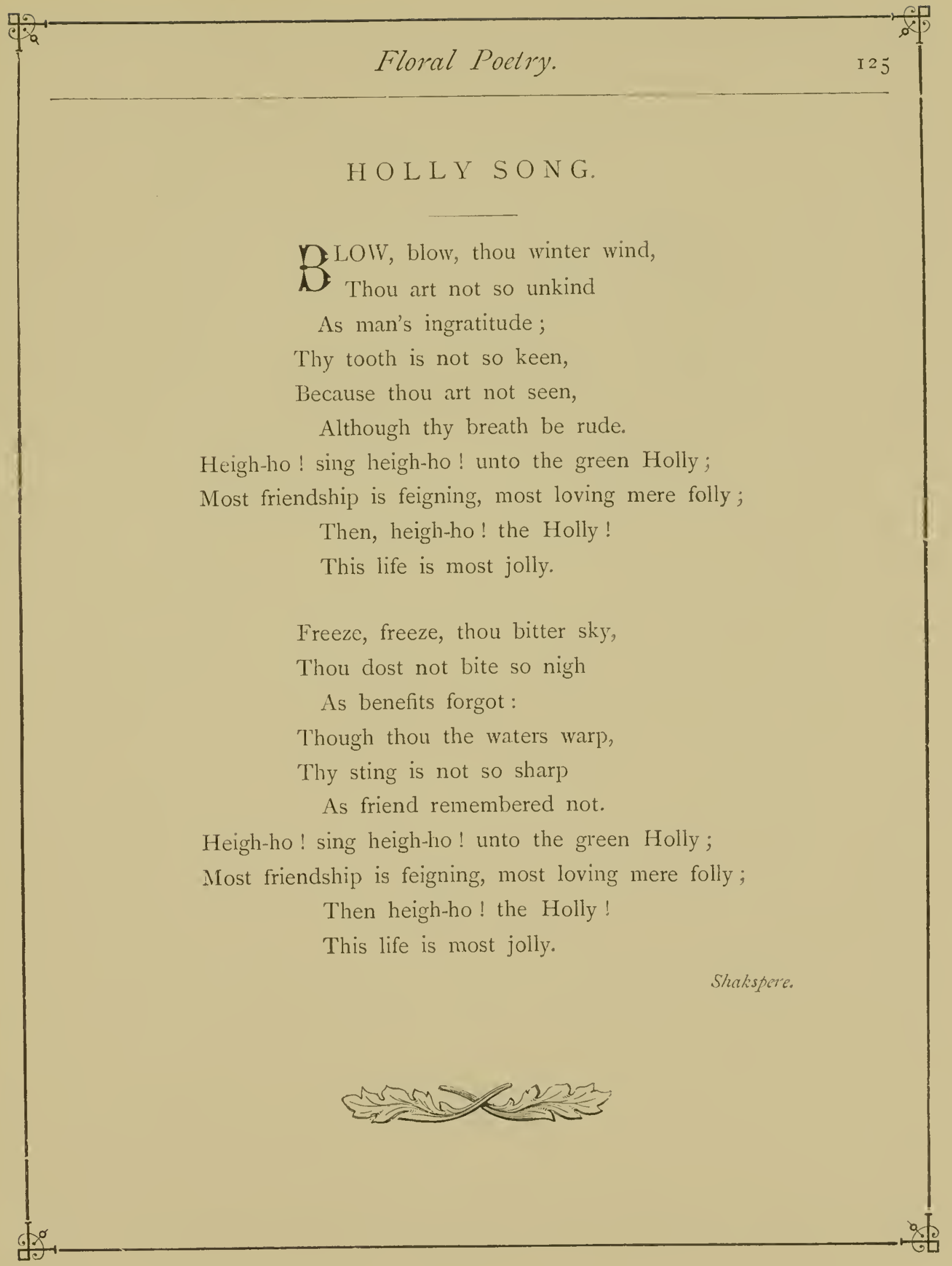




\section{THE IVY SONG.}

H! how could fancy crown with thec

In ancient days the God of Wine,

And bid thee at the banquet be

Companion of the Vine!

Thy home, wild plant, is where each sound

Of revelry hath long been o'er,

Where song's full notes once pealed around,

But now are known no more.

The Roman on his battle-plains,

Where kings before his eagles bent,

Entwined thee with exulting strains

Around the victor's tent!

Yet there, though fresh in glossy green,

Triumphantly thy boughs might wave,

Better thou lov'st the silent scene

Around the victor's grave.

Oh ! many a temple, once sublime,

Beneath a blue Italian sky,

Hath nought of beauty left by time,

Save thy wild tapestry!

And, reared 'midst crags and clouds, 'tis thine

To wave where banners waved of yore,

O'er towers that crest the noble Rhine,

Along the rocky shore.

High from the fields of air look down

Those eyries of a vanished race,

Homes of the mighty, whose renown

Hath passed, and left no trace. 


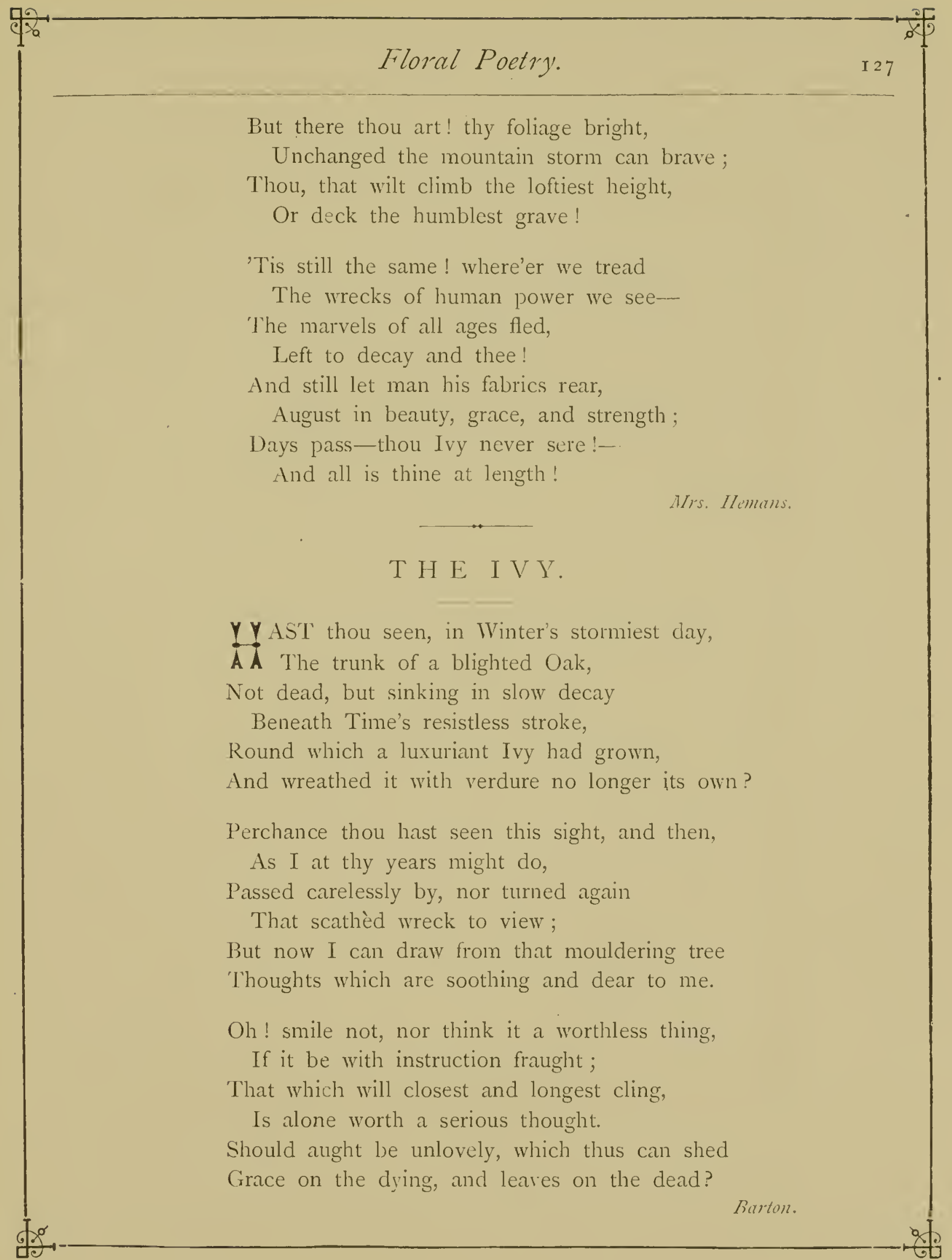




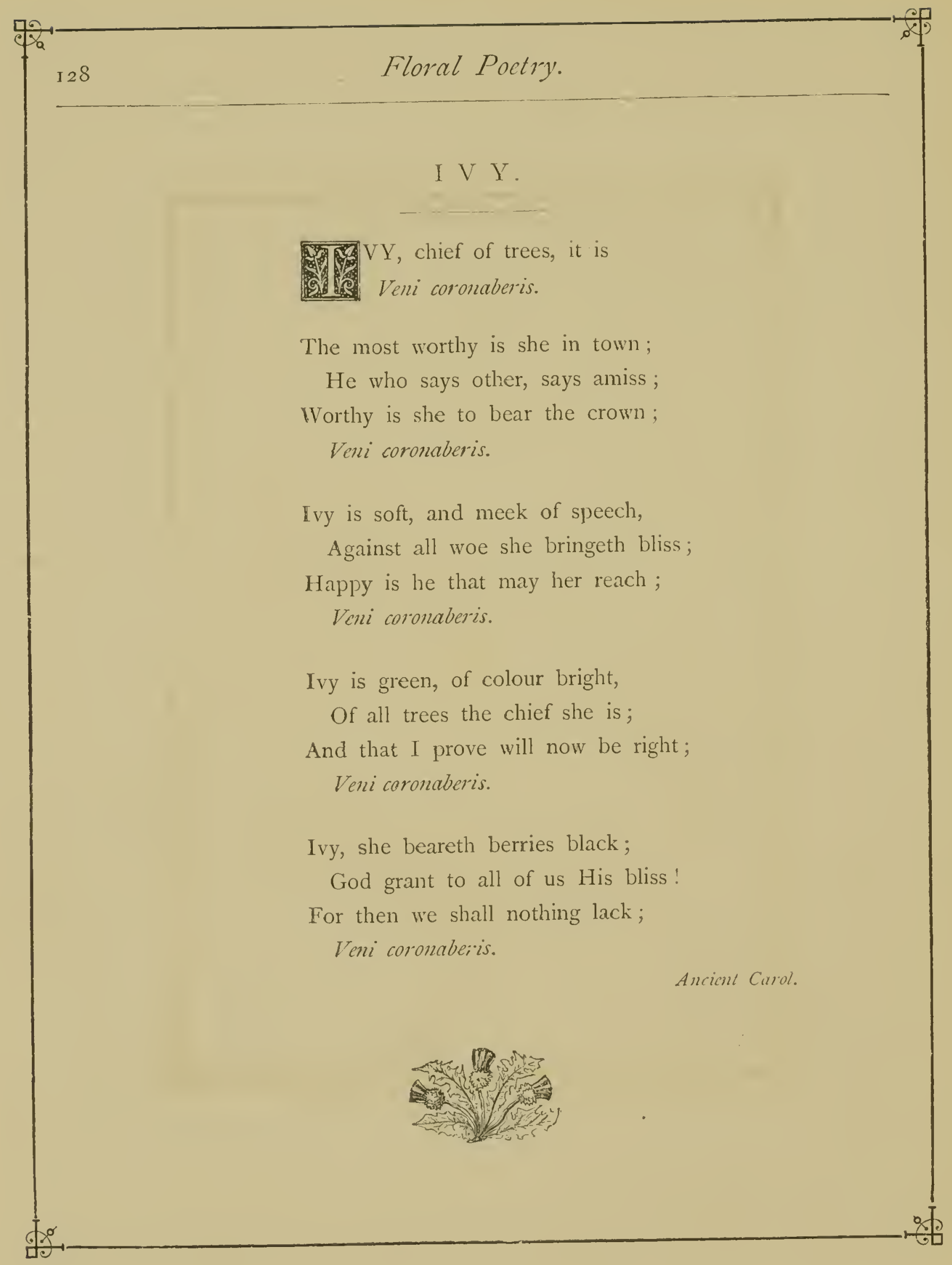




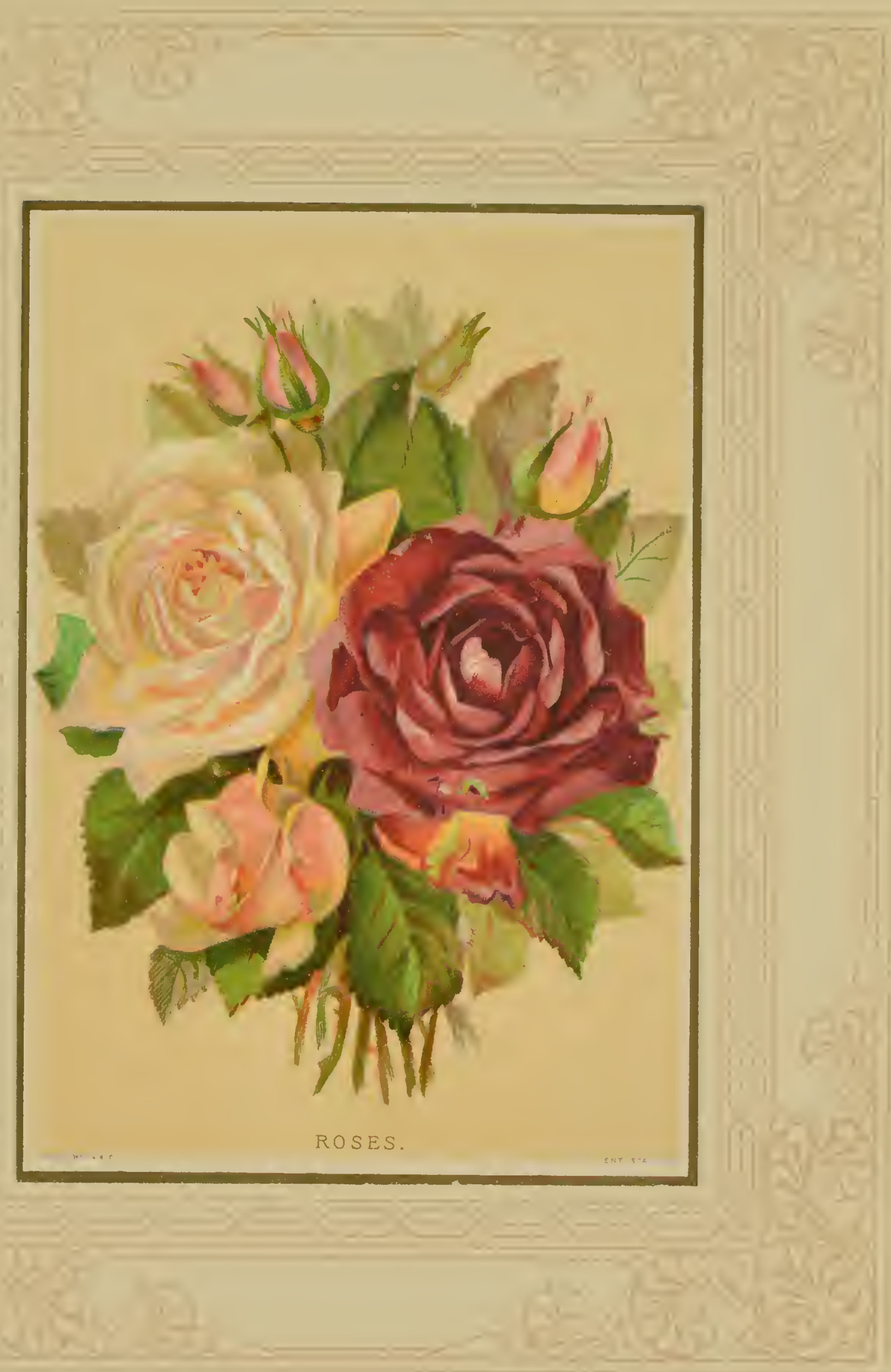





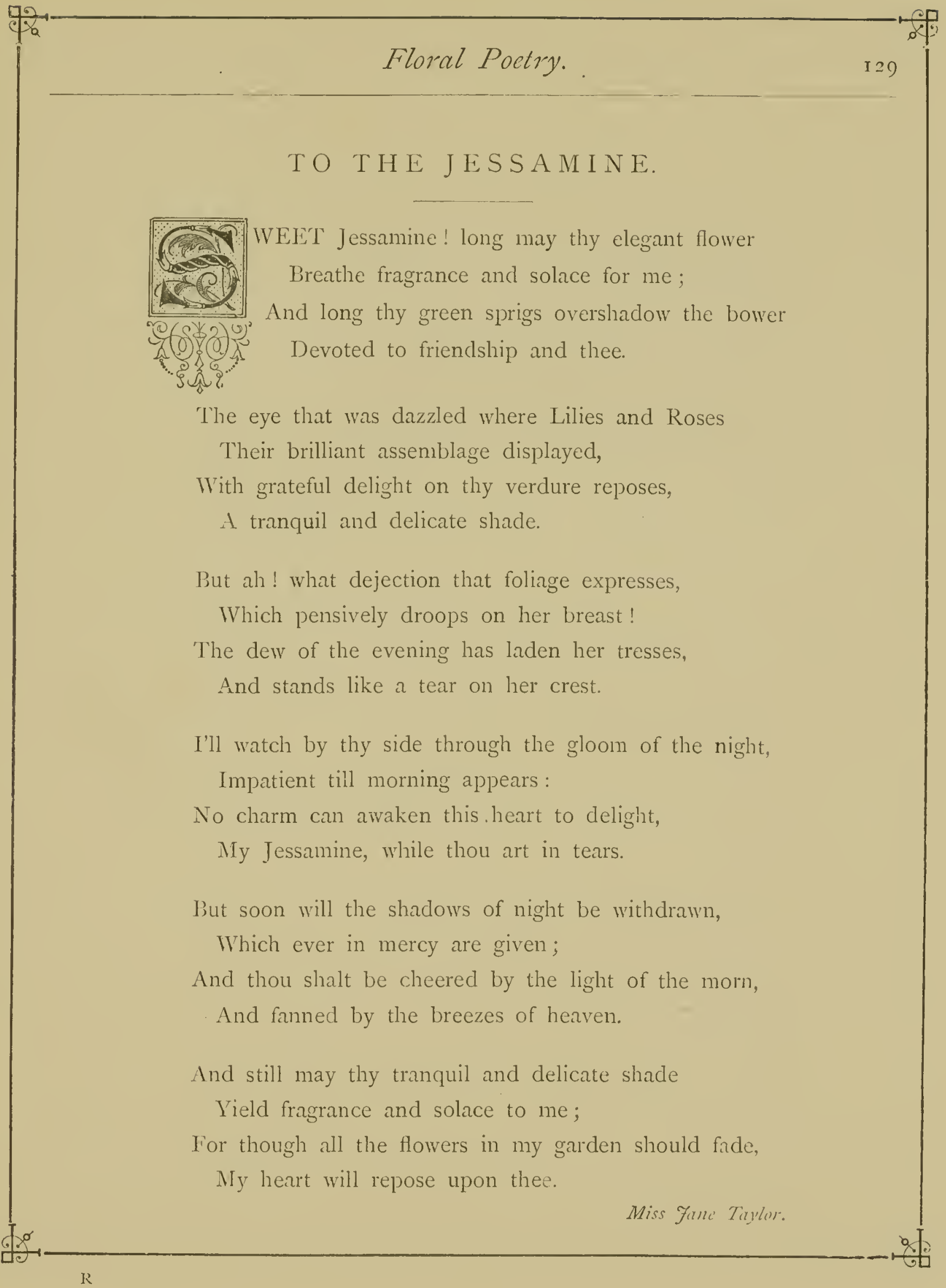




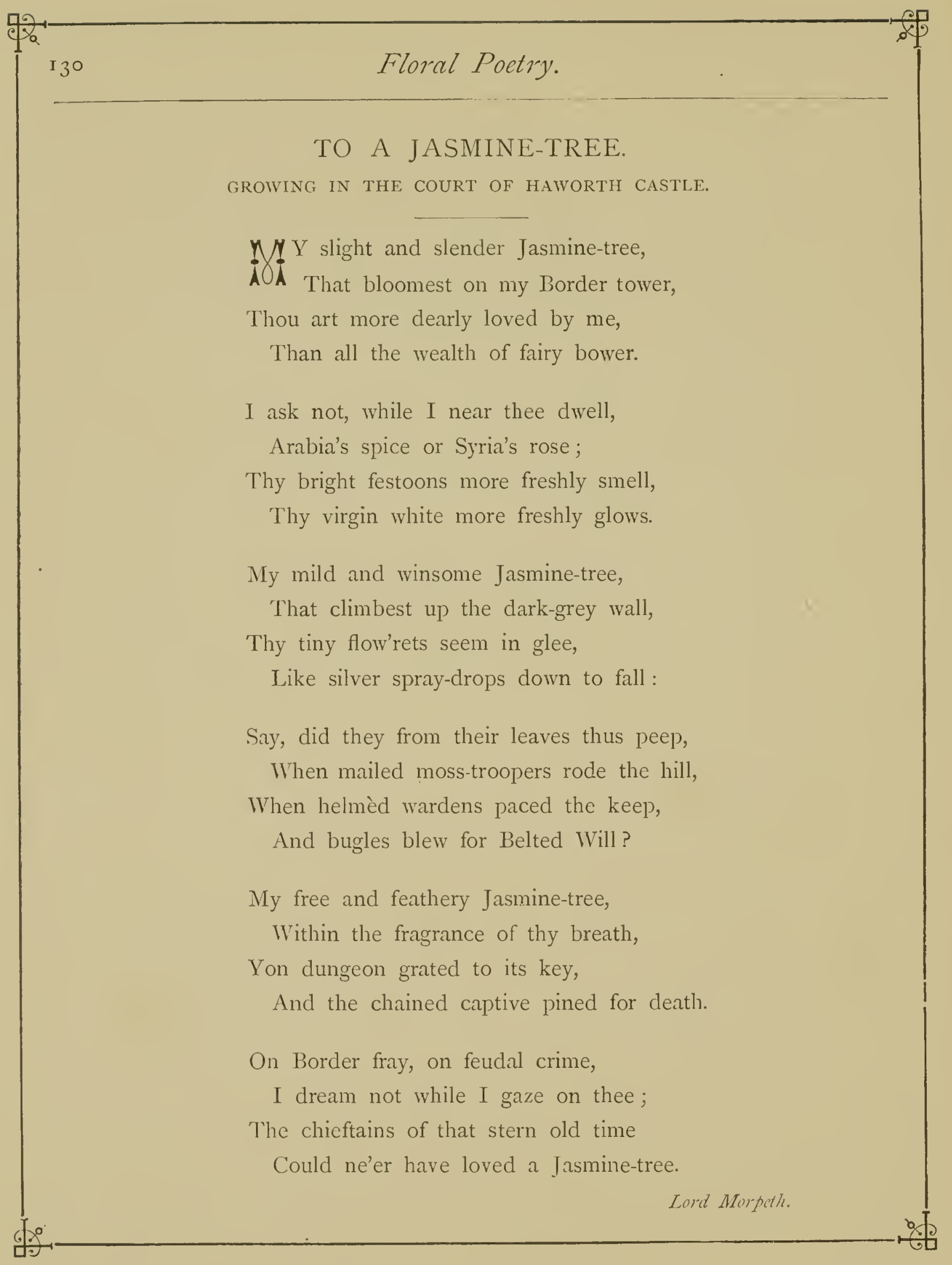




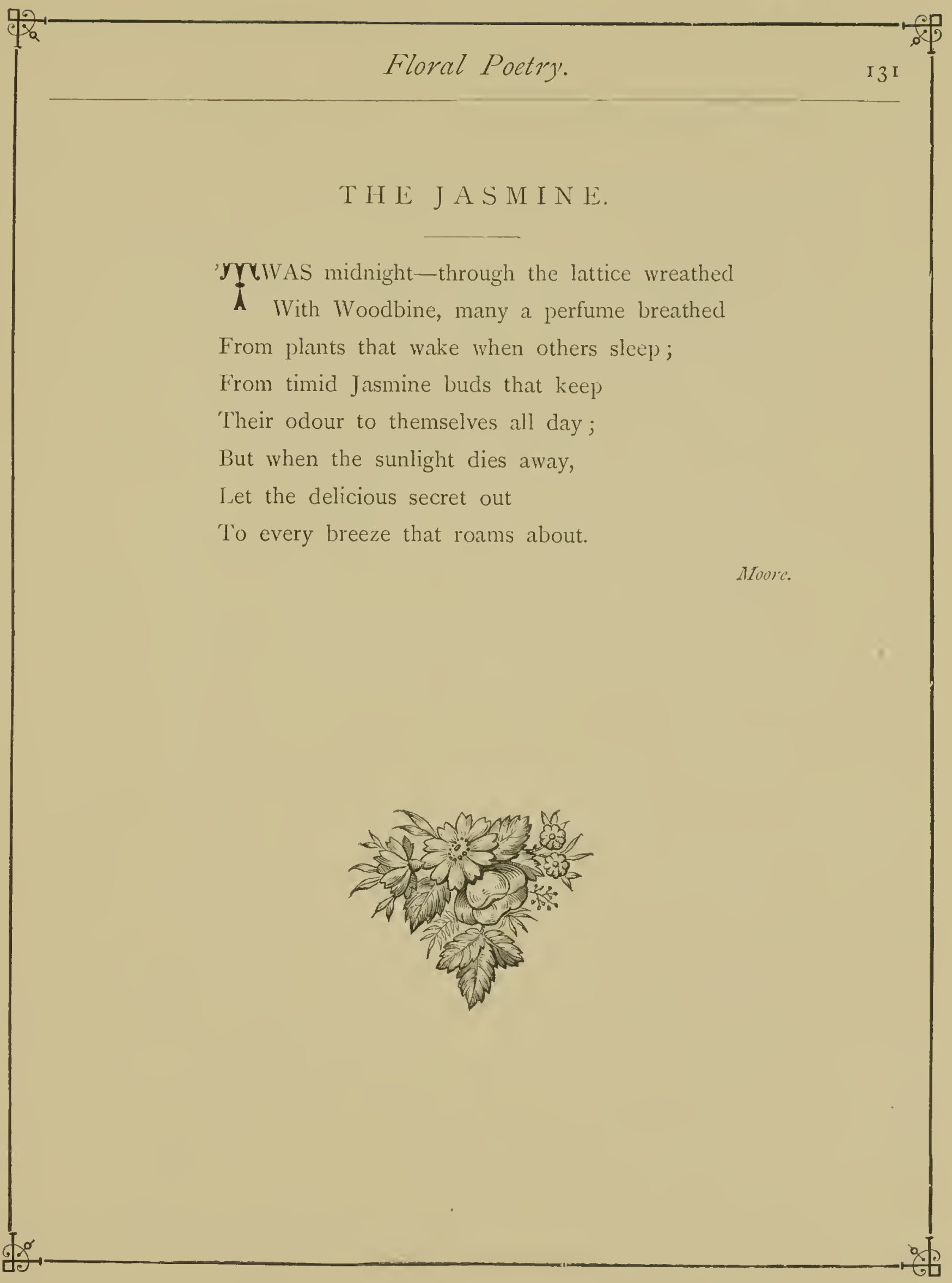




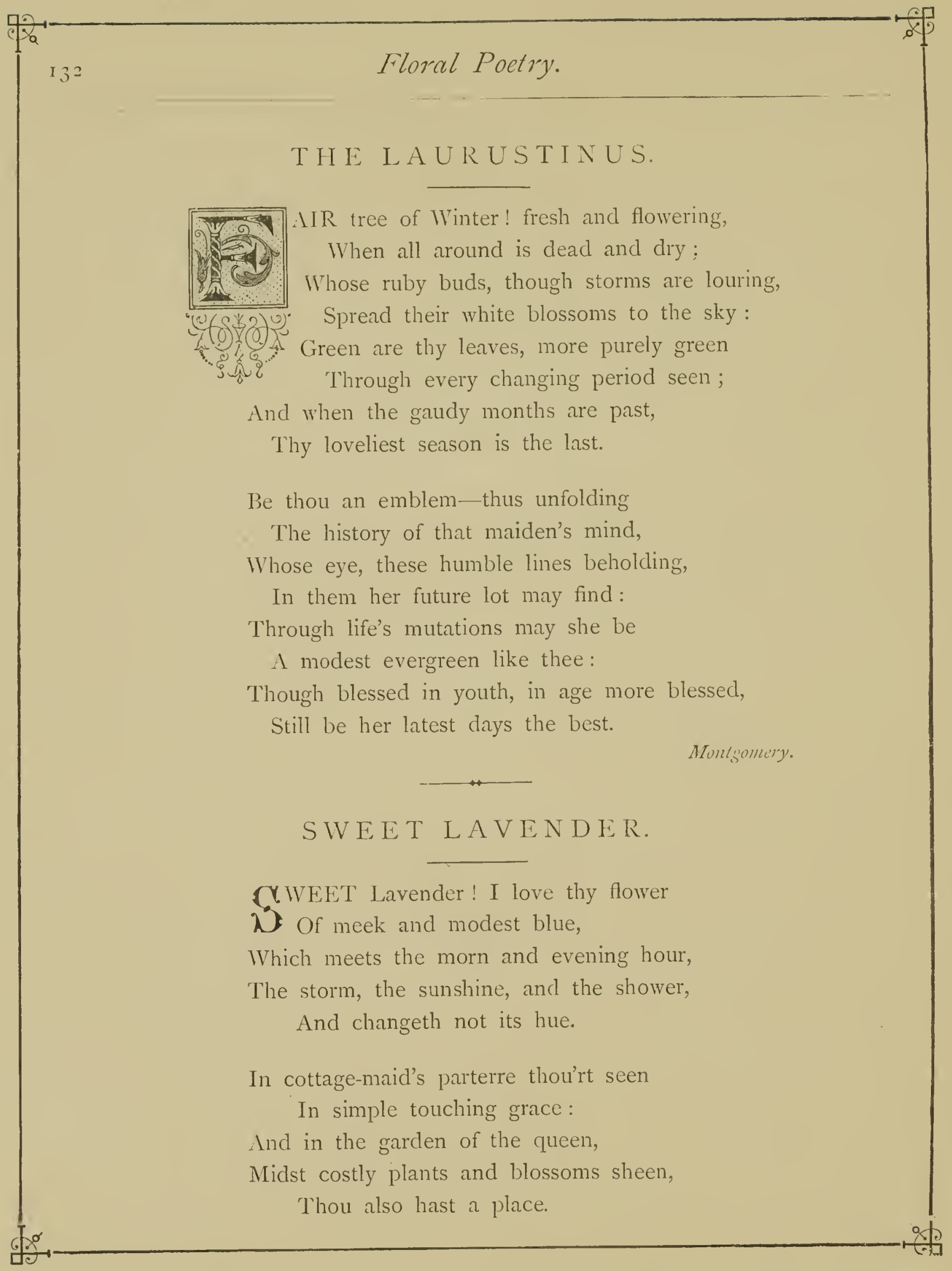




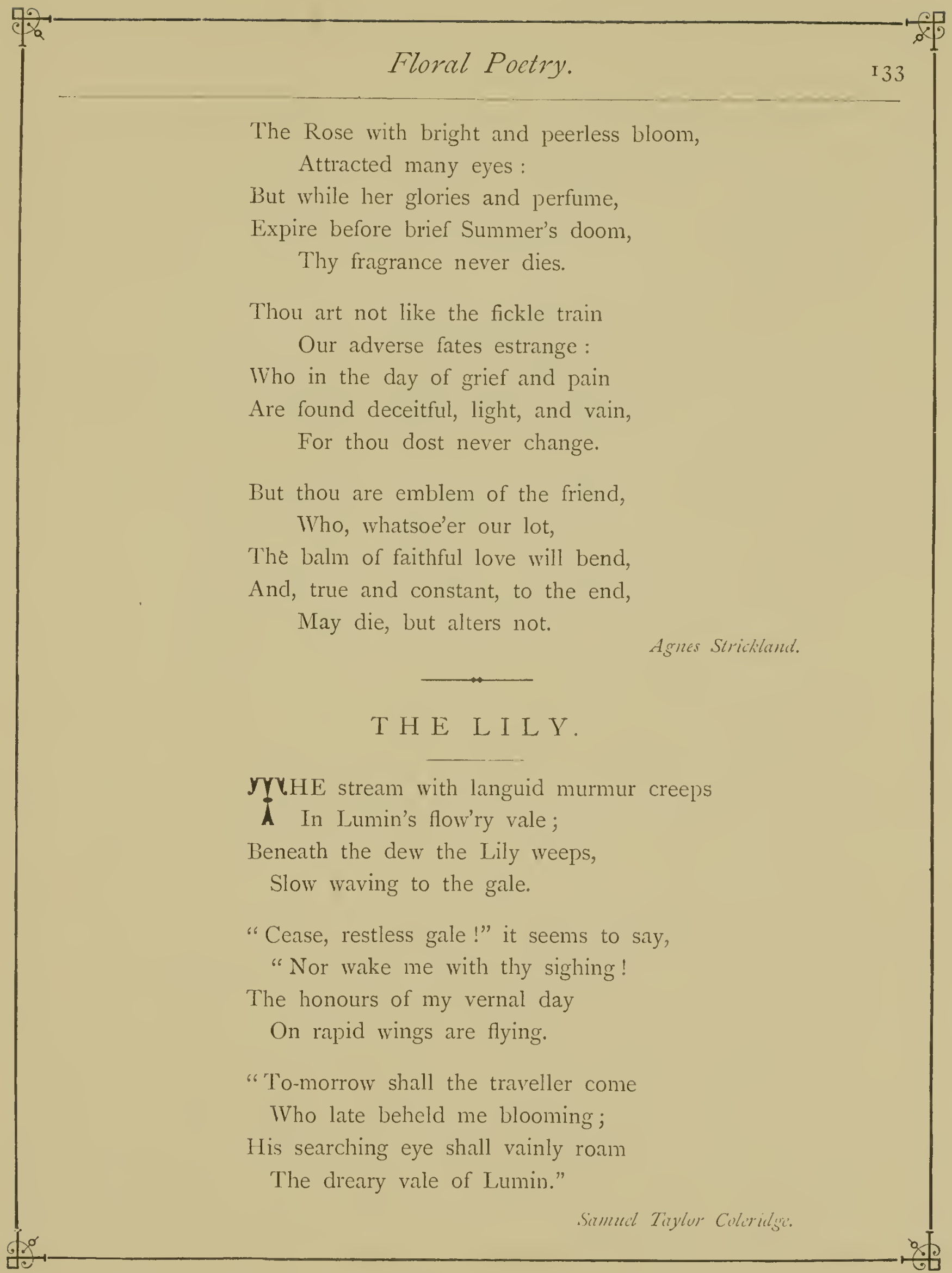




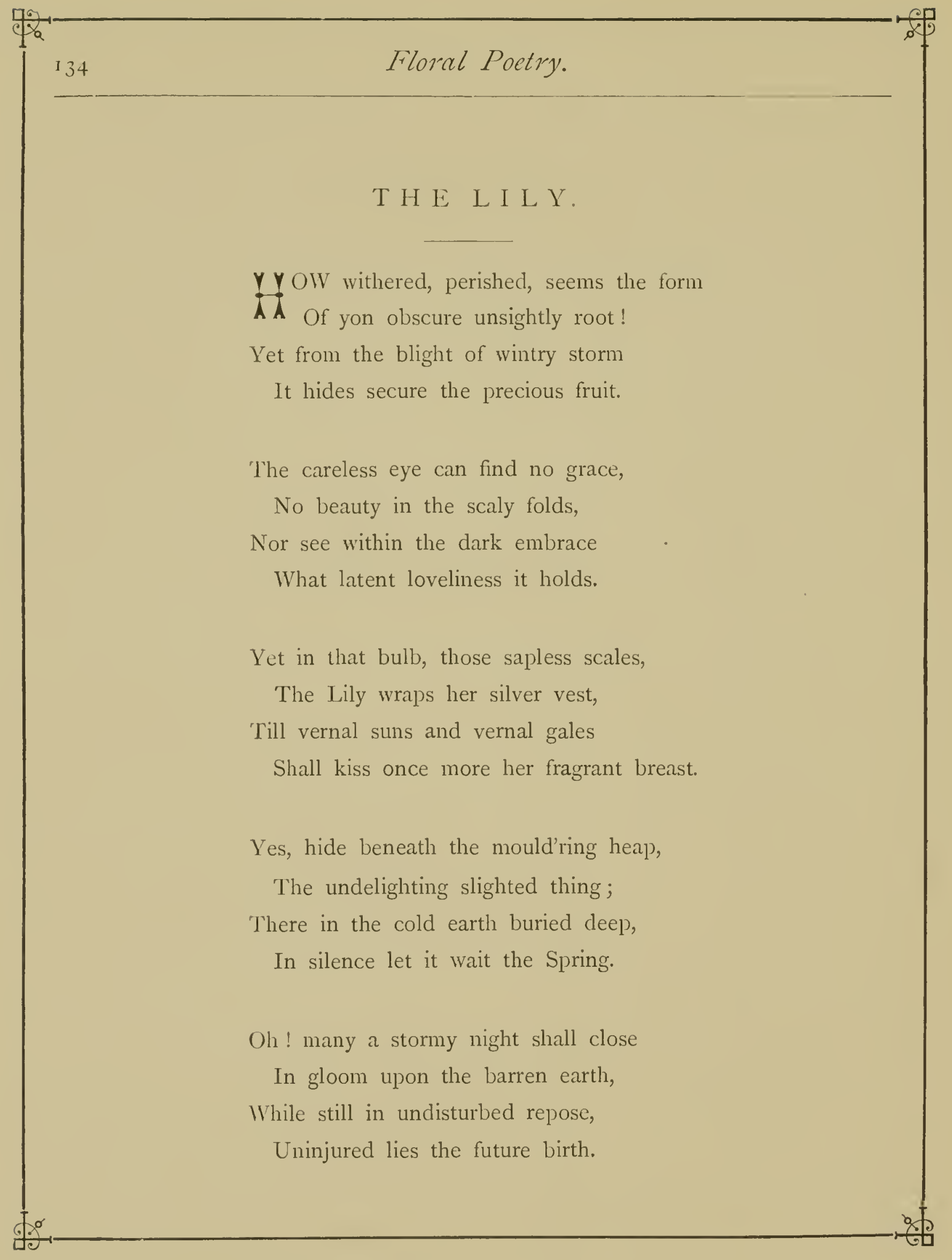




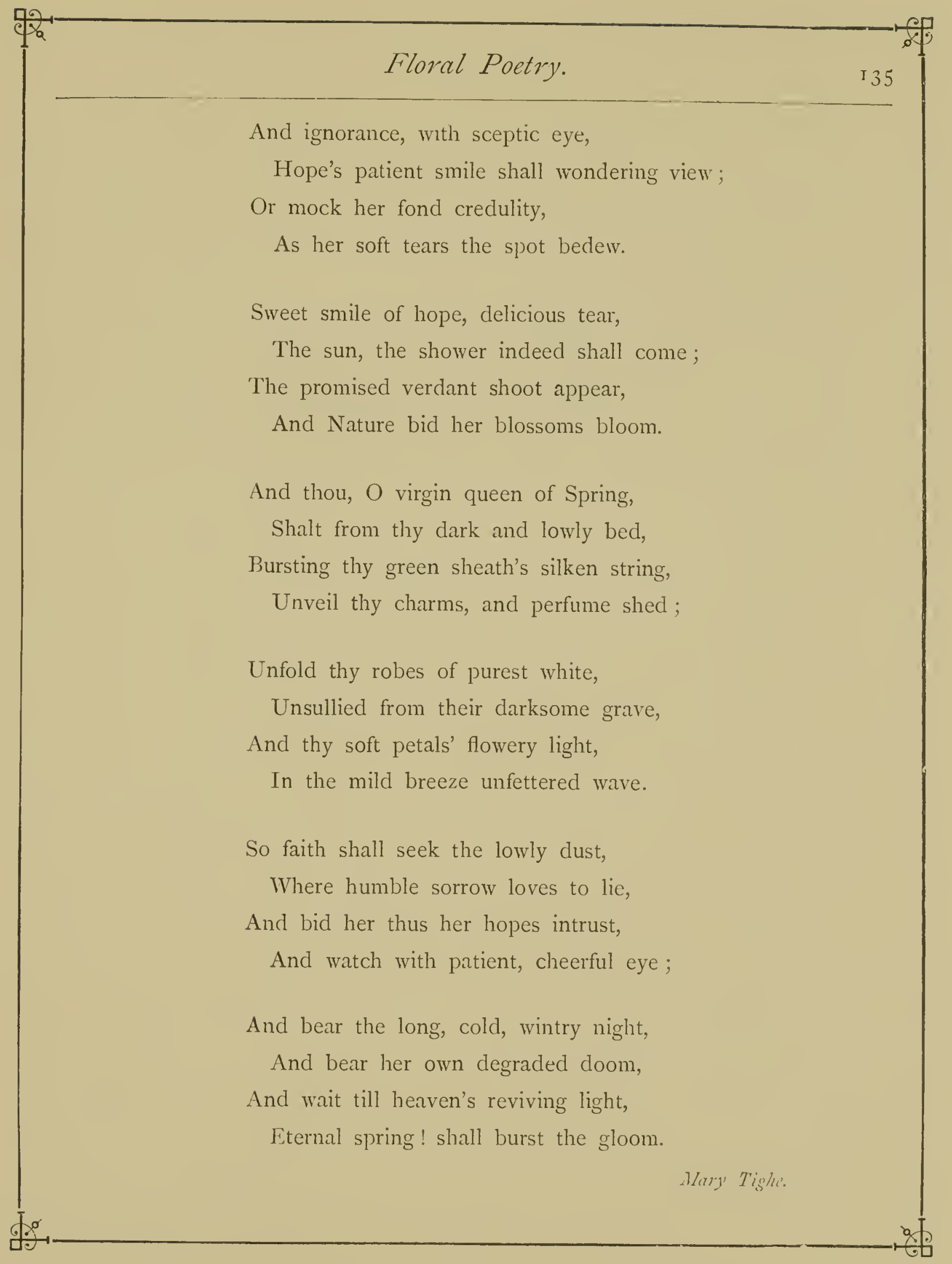




\section{THE LILY AND THE ROSE.}

rrute nymph must lose her female friend,

$\bar{\lambda}$ If more admired than she-

But where will fierce contention end,

If flowers can disagree?

Within the garden's peaceful scene

Appeared two lovely foes,

Aspiring to the rank of queen-

The Lily and the Rose.

The Rose soon reddened into rage,

And, swelling with disdain,

Appealed to many a poet's page

To prove her right to reign.

The Lily's height bespoke command,

A fair imperial flower;

She seemed designed for Flora's hand,

The sceptre of her power.

This civil bickering and debate

The goddess chanced to hear,

And flew to save, ere yet too late,

The pride of the parterre.

"Yours is," she said, "the noblest hue,

And yours the statelier mien;

And, till a third surpasses you,

I.et each be deemed a queen." 


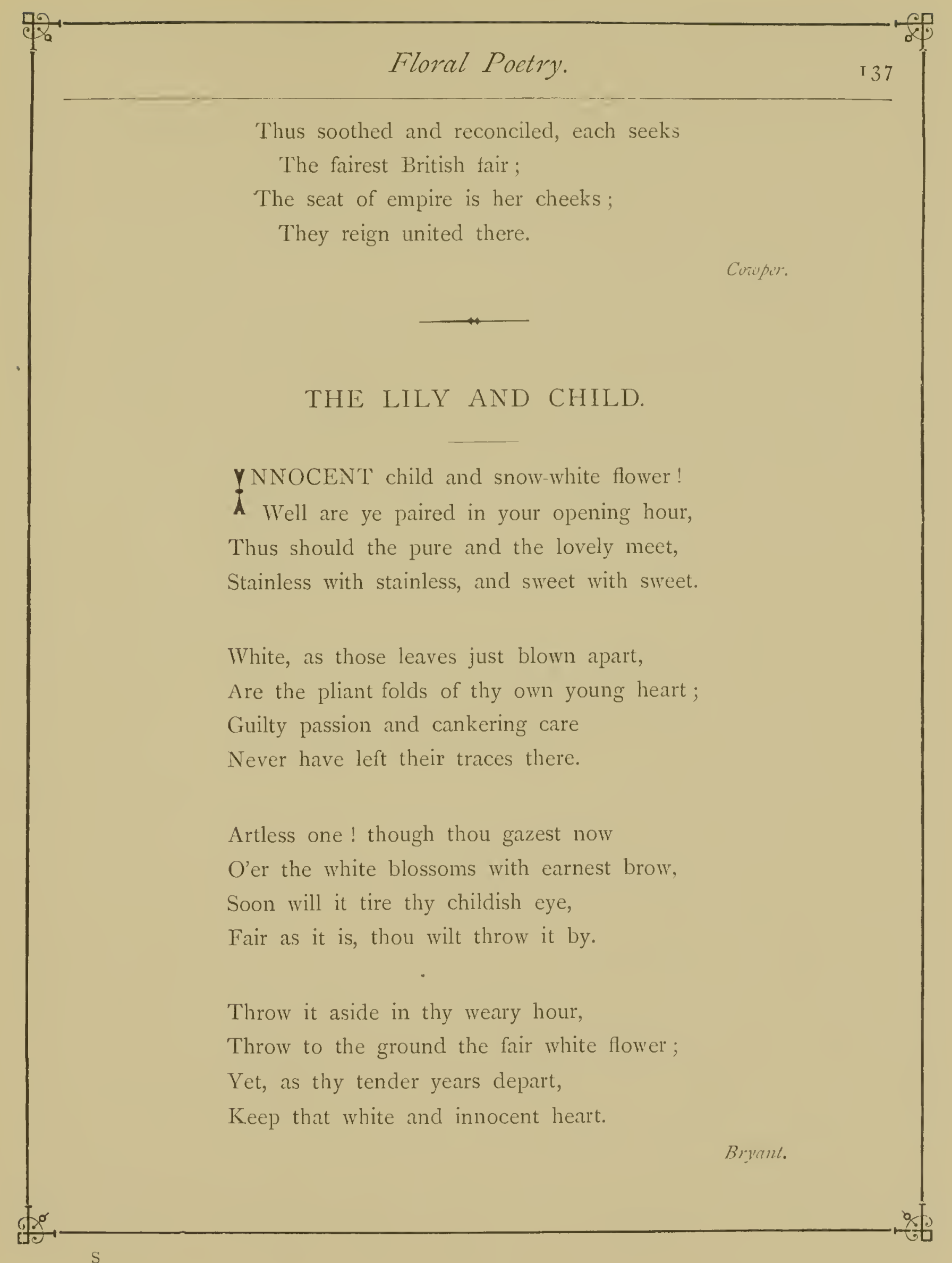




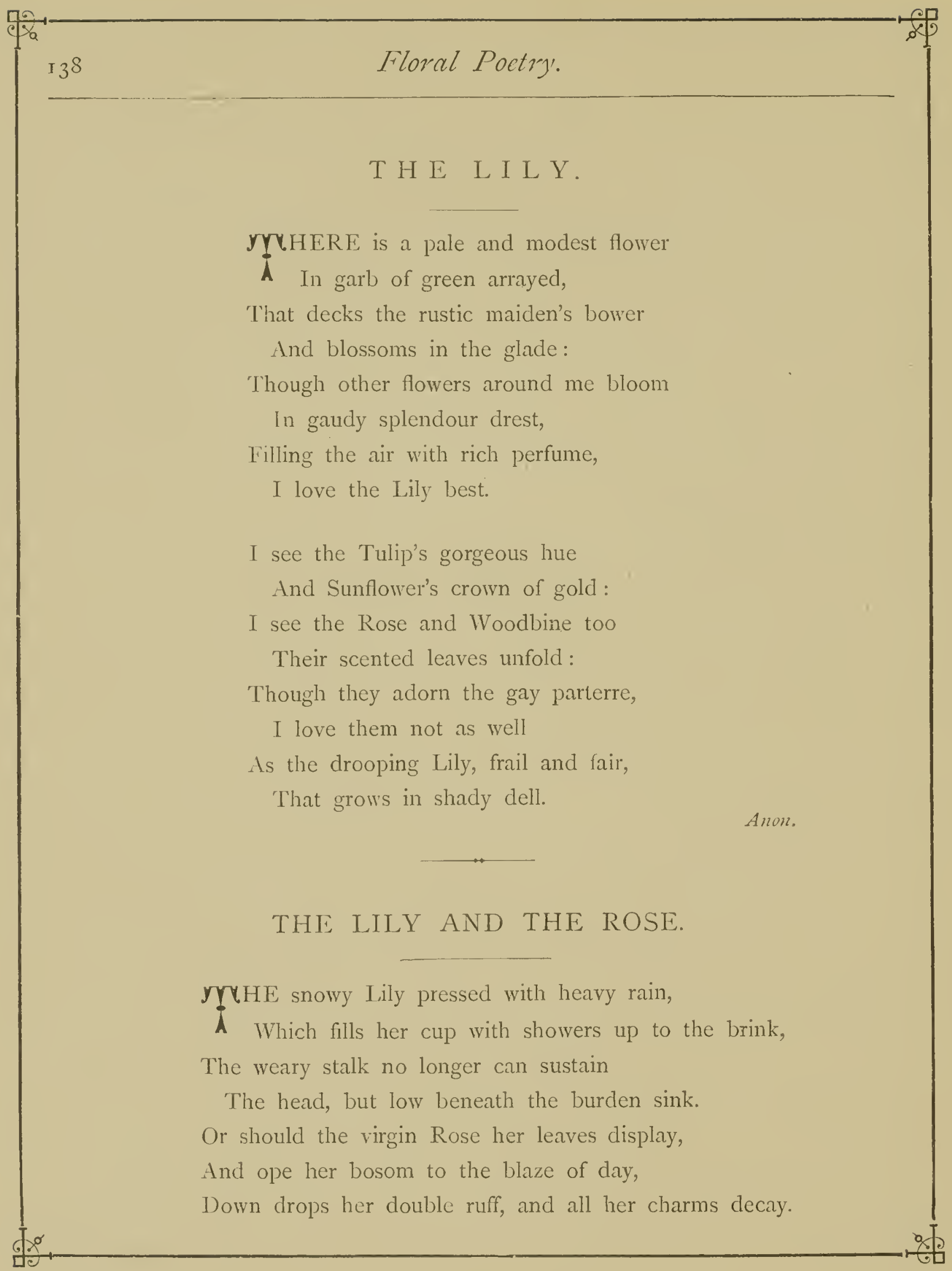




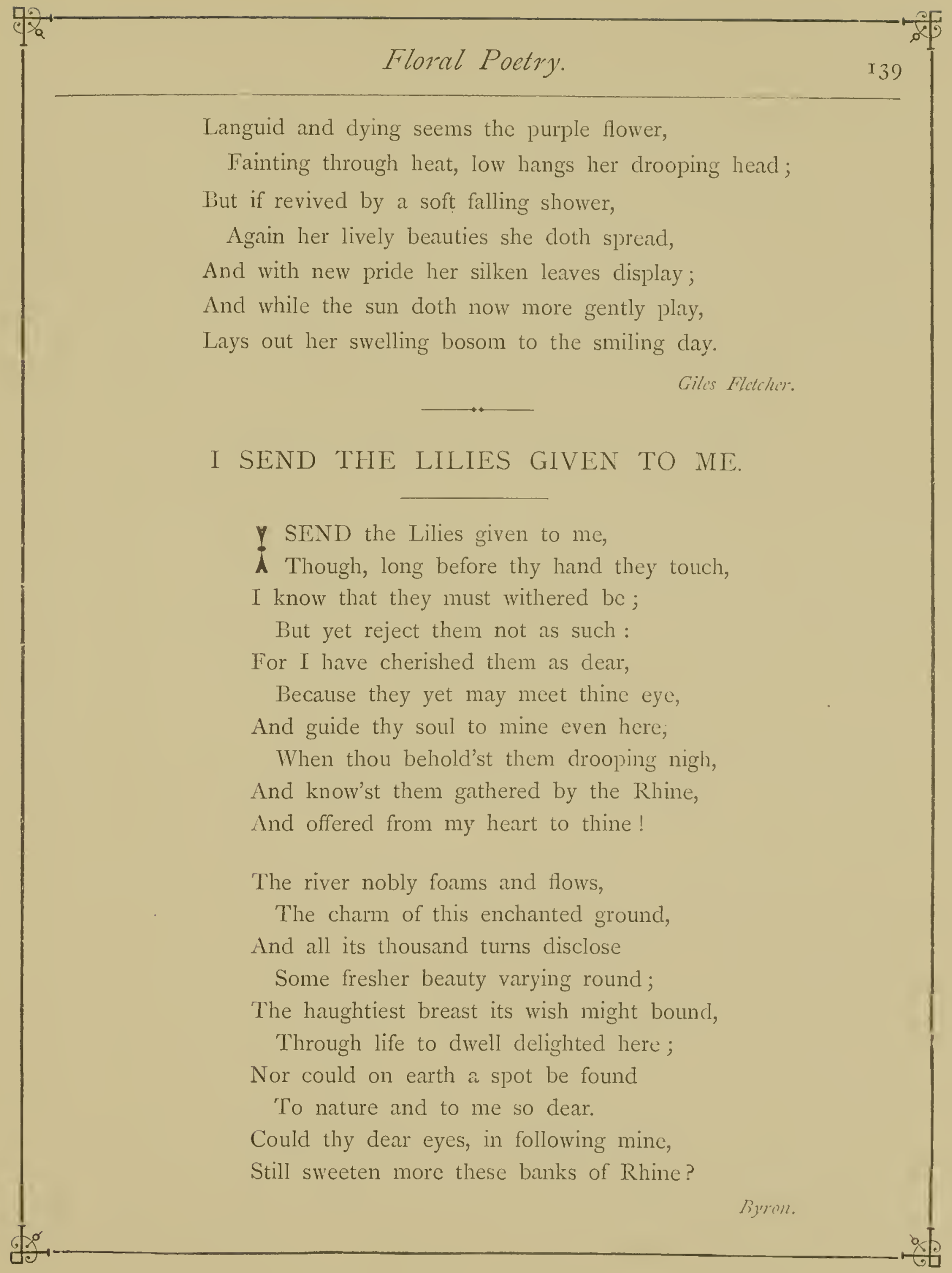




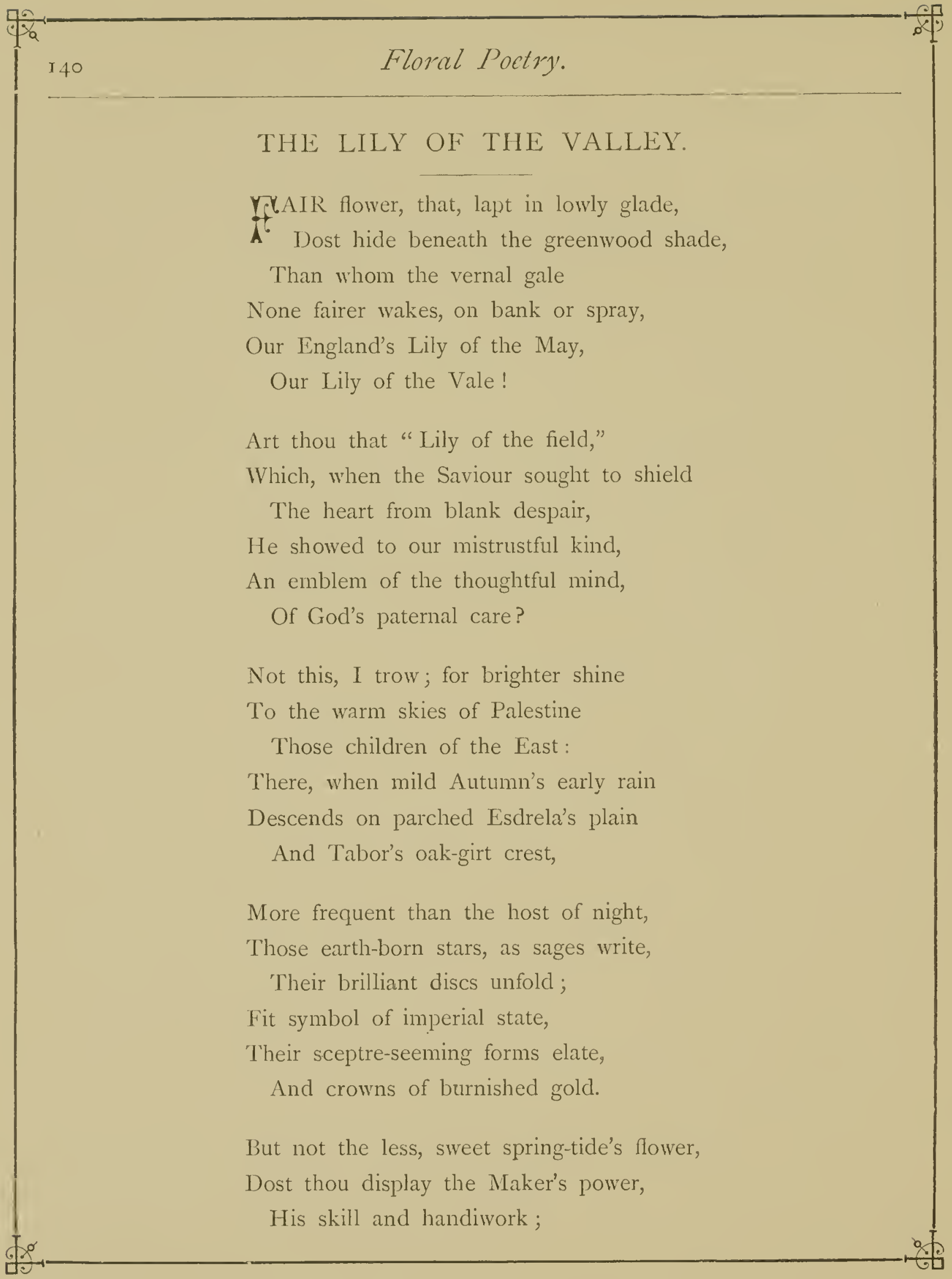




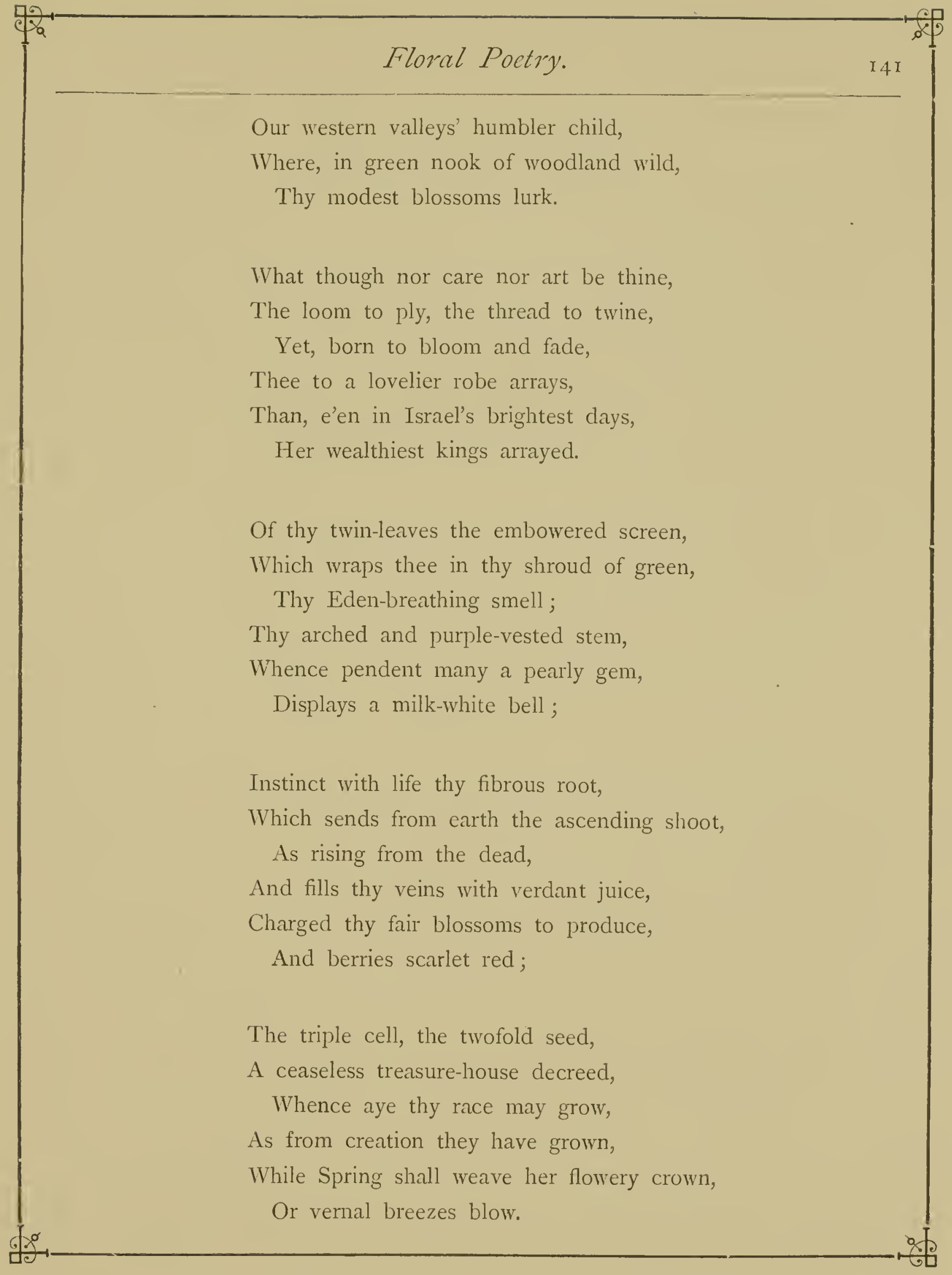




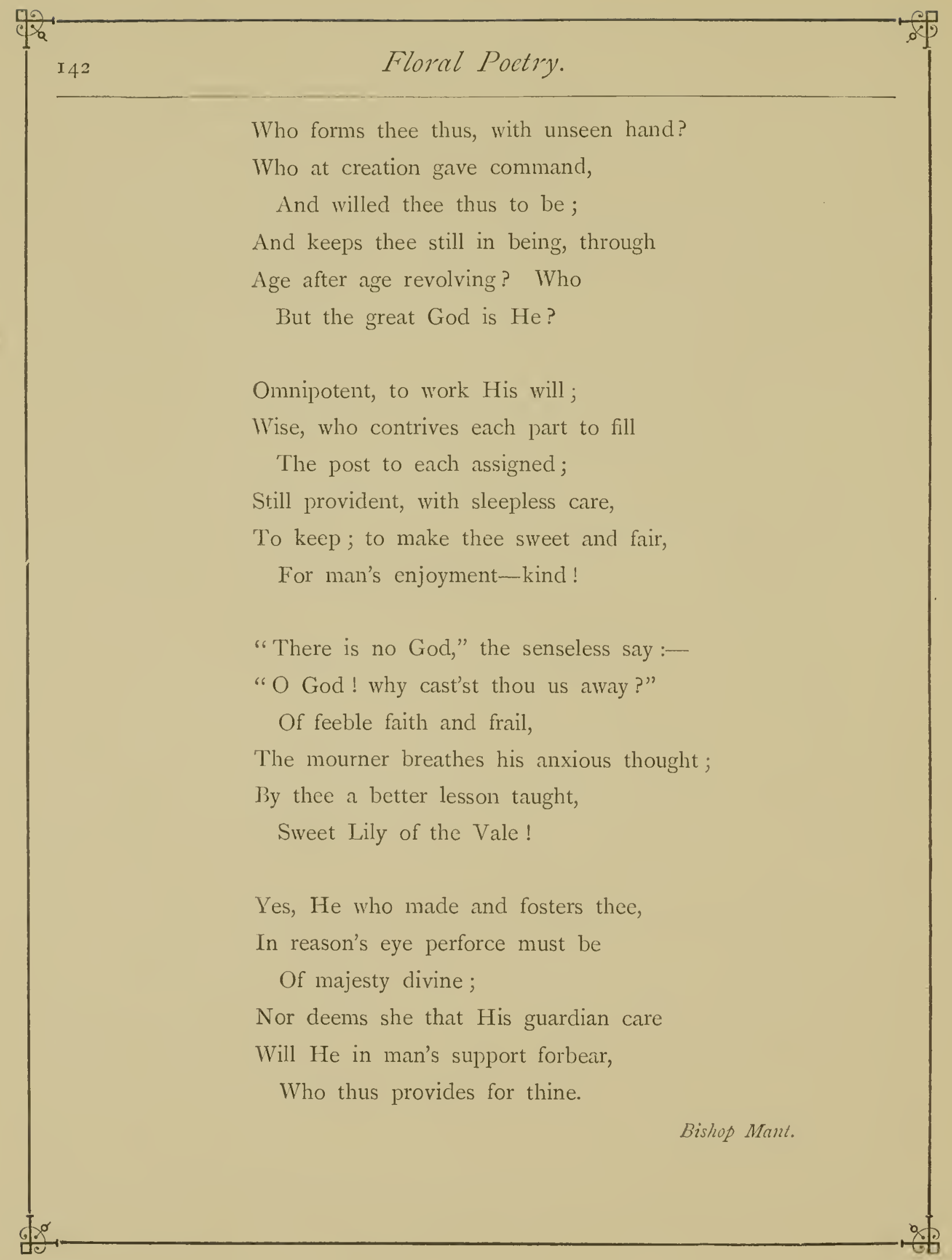




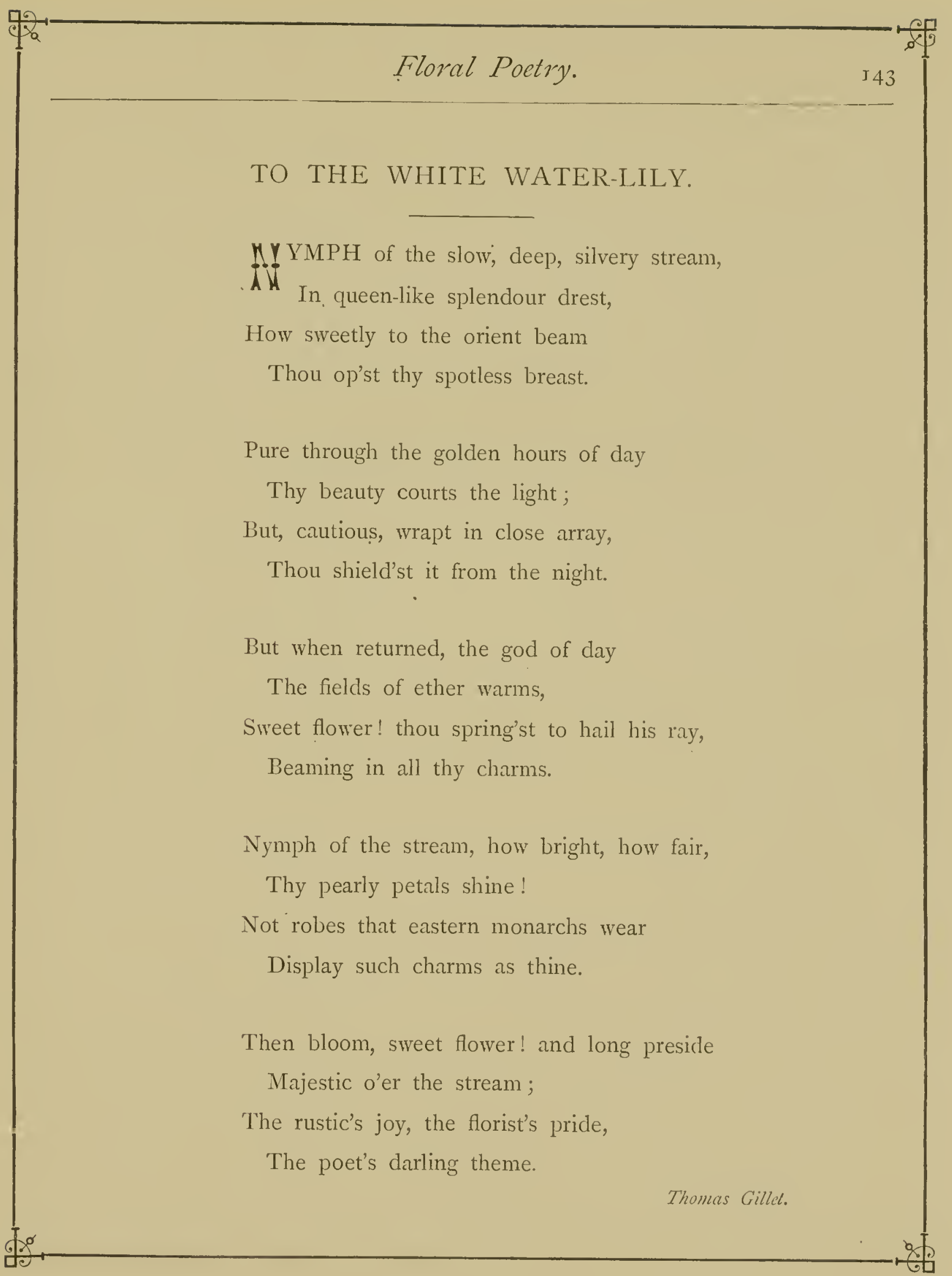




\section{LILIES OF THE VALLEY.}

YOU dream not, as the soft wind stirs

A Those little fairy bells,

How to my heart sad pleasure comes, Each cup a story tells.

They bring before my eyes a form

As fragile and as sweet;

I seem again to hear the fall

Of her light tripping feet.

Once more, as in the olden days,

Her small hand clasped in mine,

I wander through cool mossy paths

Beneath the fragrant pine;

Around that fair young head I bind

Wreaths of the fragrant flowers;

And silently we watch the stars,

And pass away glad hours.

The morning dawn, the sultry noon,

The hours of calm midnight,

Still found us ever side by side,

Still found my flower bright.

Trembling, I gaze in those deep eyes,

So full of earnest love;

No taint of earth, as years passed on,

Could stain my snowy dove. 


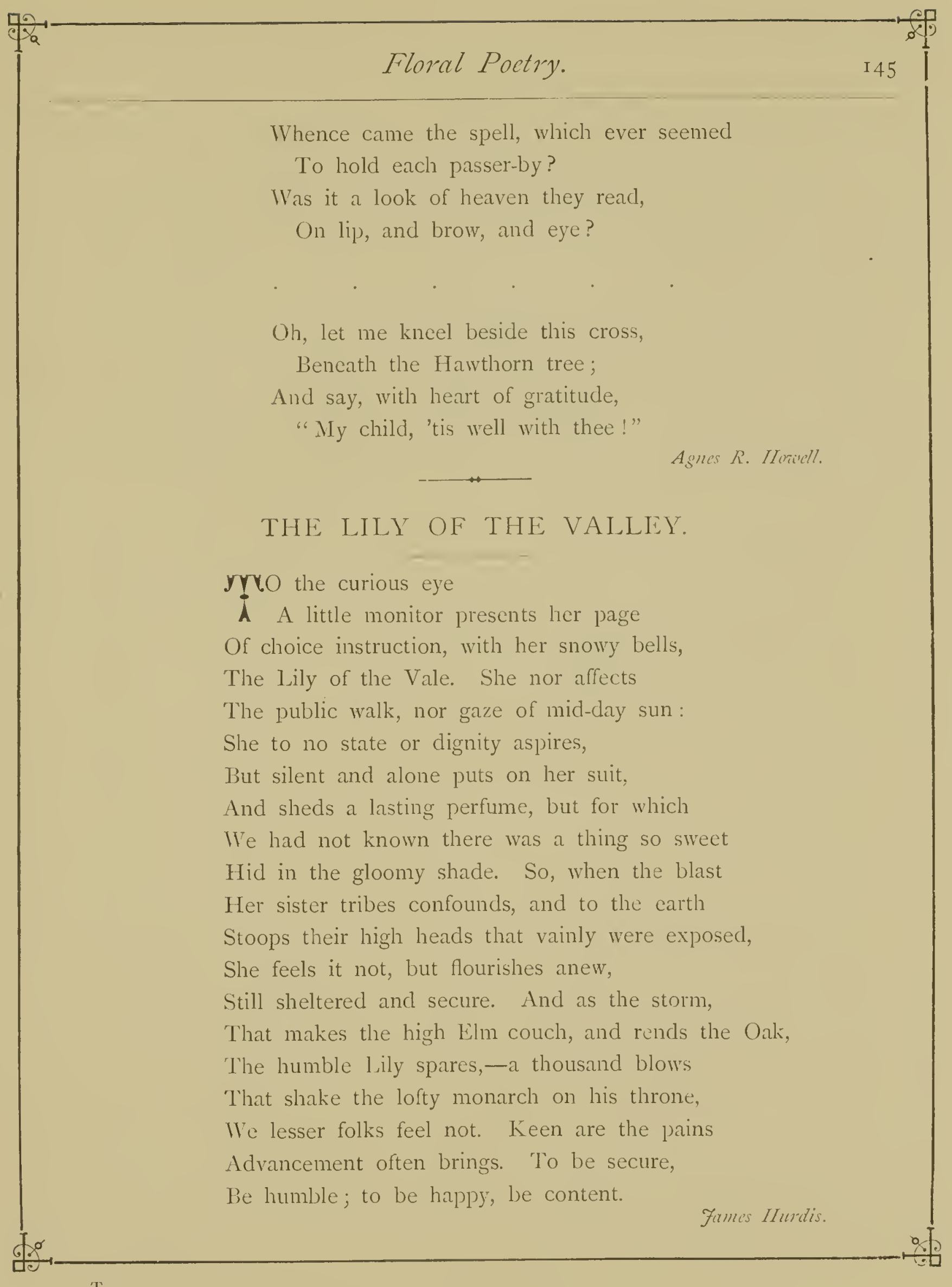




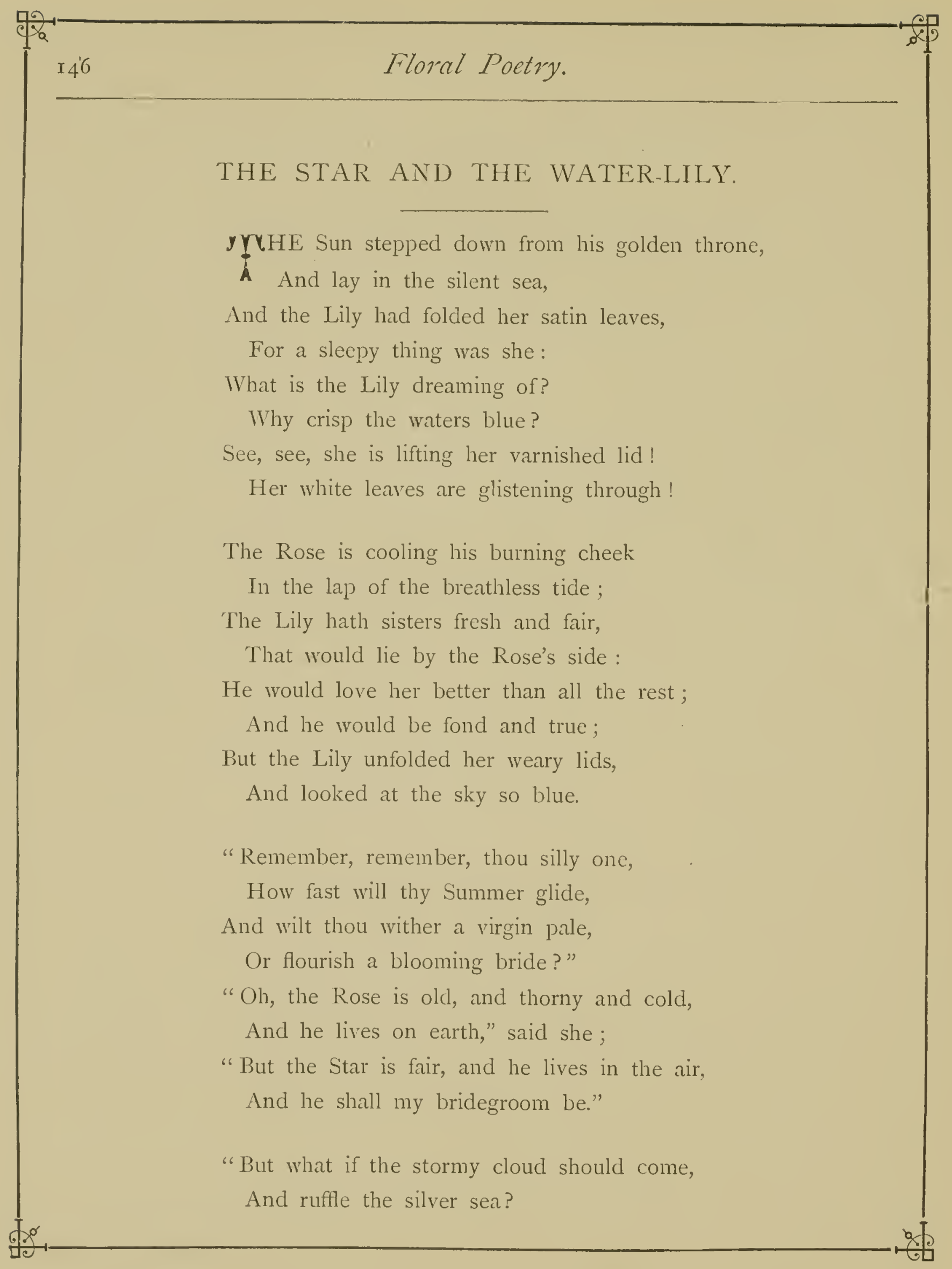




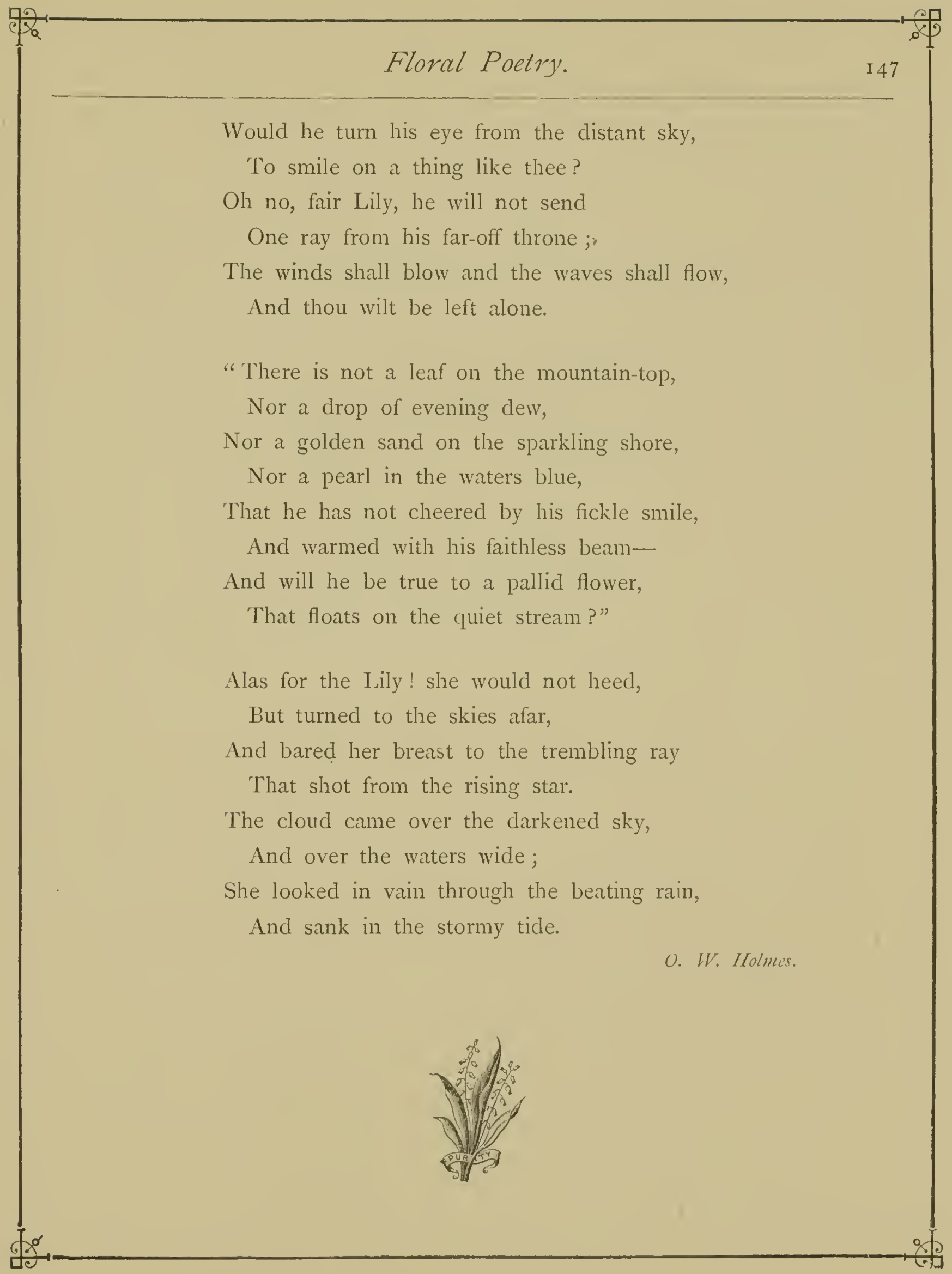




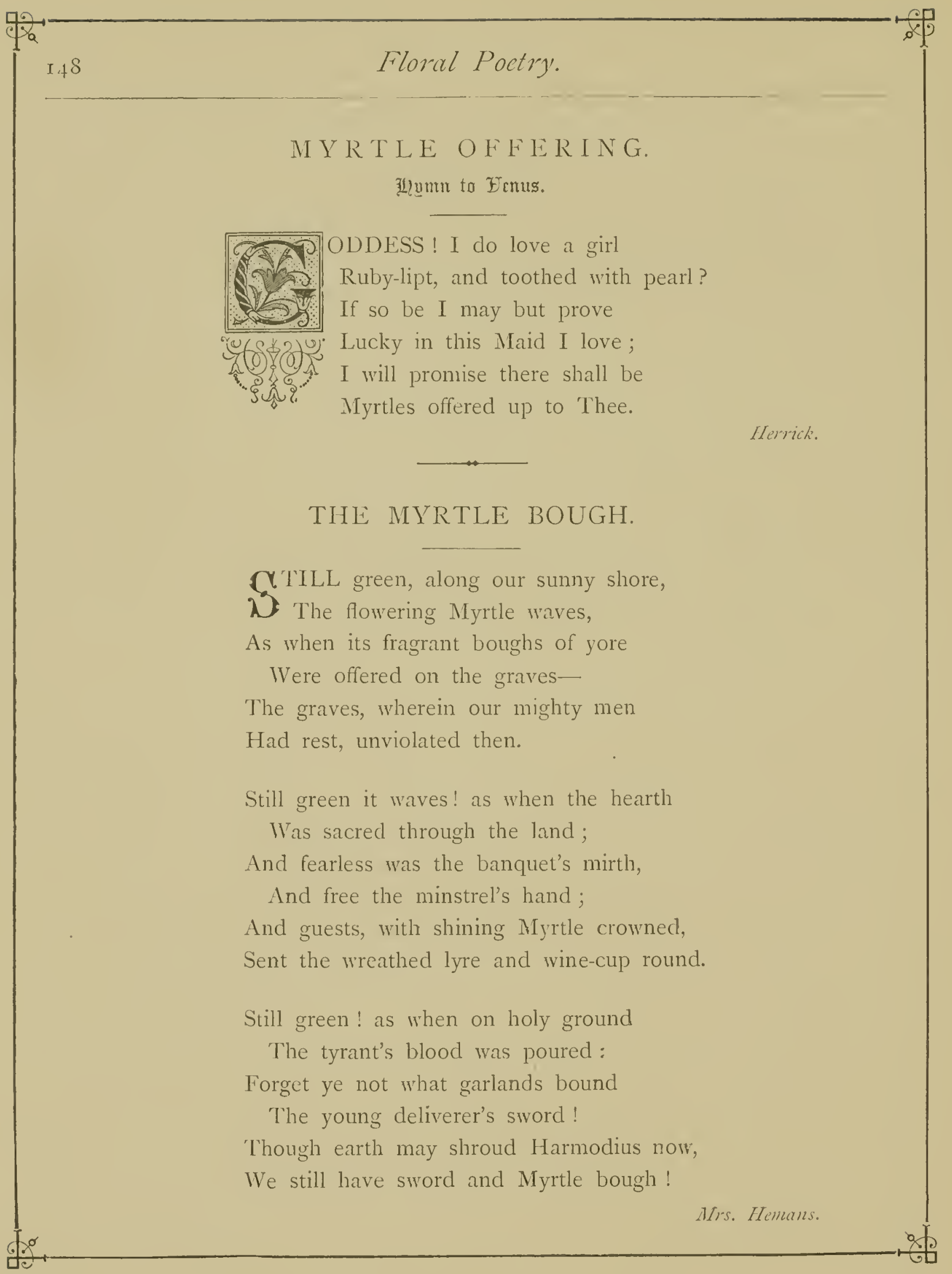




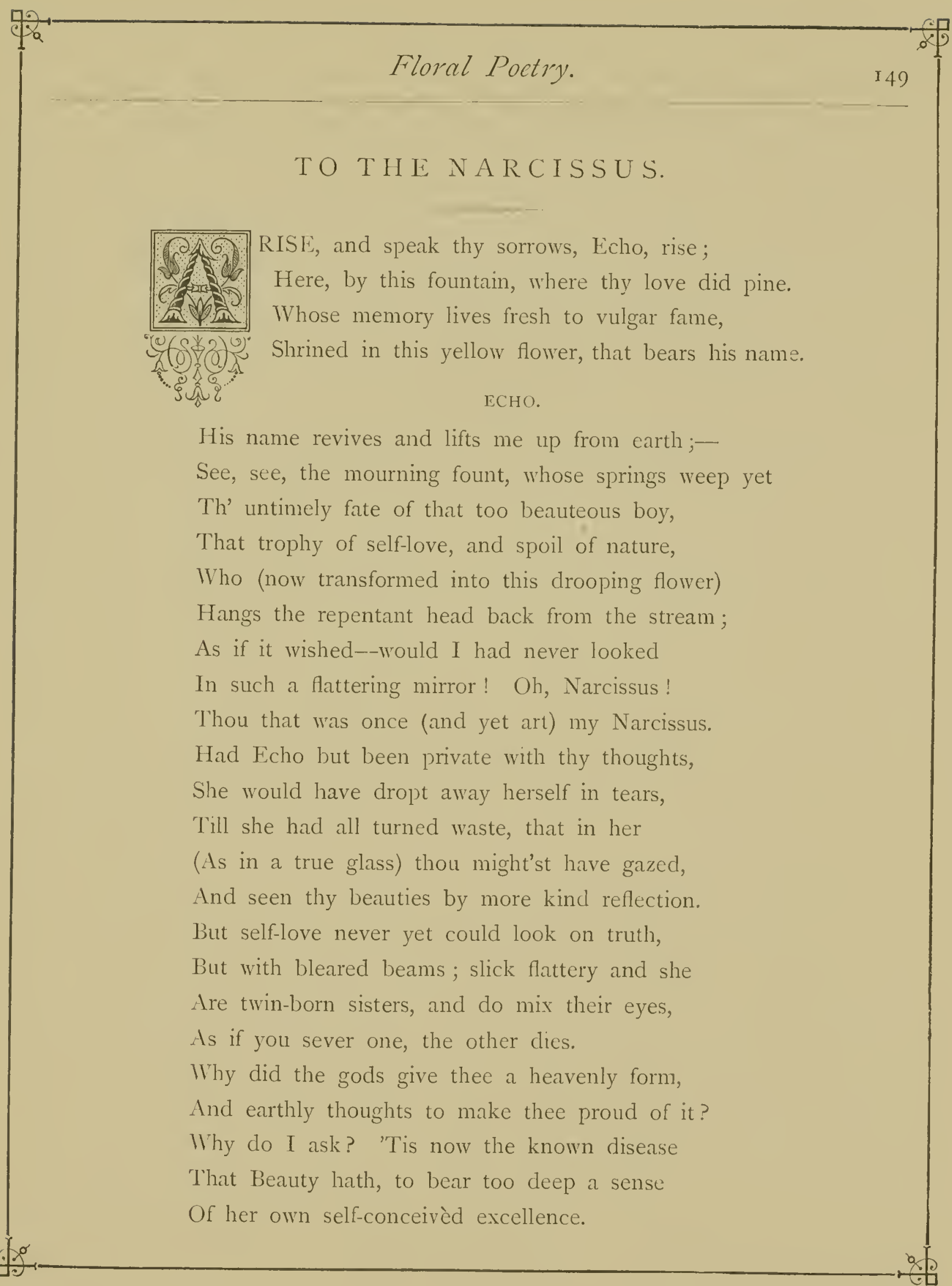




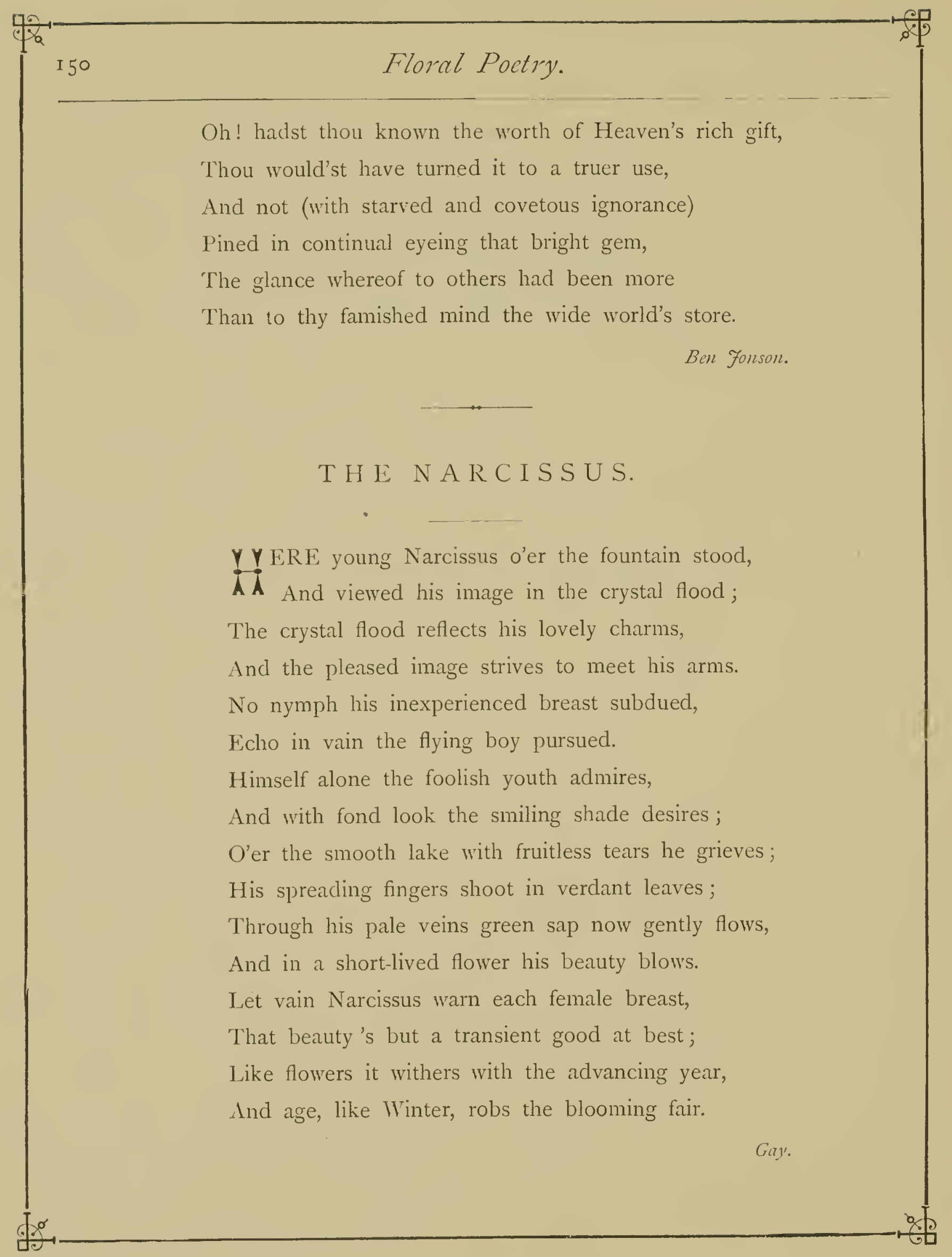




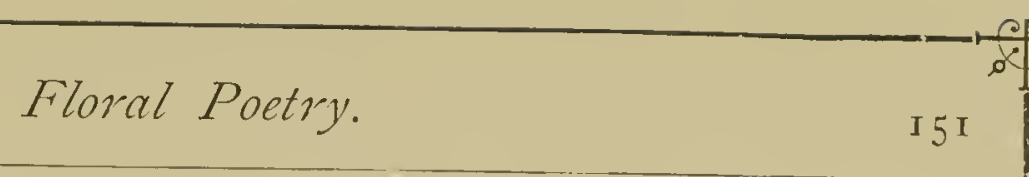

THE NARCISSUS.

H HAT first inspired a bard of old to sing

Narcissus pining o'er the untainted spring?

In some delicious ramble he had found

A little space, with boughs all woven round;

And in the midst of all a clearer pool

Than e'er reflected in its pleasant cool

The blue sky, here and there serenely peeping,

Through tendril wreaths fantastically creeping;

And on the bank a lonely flower he spied,

A meek and forlorn flower, with nought of pride,

Drooping its beauty o'er the watery clearness,

To woo its own sad image into nearness;

Deaf to light Zephyrus it would not move,

But still would seem to droop, to pine, to love.

So while the poet stood in this sweet spot,

Some fainter gleamings o'er his fancy shot;

Nor was it long ere he had told the tale

Of young Narcissus, and sad Echo's vale.

Kéts.

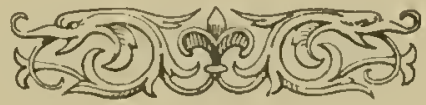


THE NIGHTINGALE FLONER.

Y.AIR flower of silent night:

$\mathbb{A}^{*}$ Unto thy bard an emblem thou should'st be His fount of song in hours of garish light

Is closed, like thee.

But with the vesper hour

Silence and solitude its depths unseal;

Its hidden springs, like thy unfolding flower,

Their life reveal.

Were it not sweeter still

To give imagination holier scope

And deem that thus the future may fulfil

A loftier hope?

That as thy lovely bloom

Sheds round its perfume at the close of day,

With beauty sweeter from surrounding glnom,

$$
\text { A star-like ray;- }
$$

So in life's dark decline,

When the grave's shadows are around me cast,

My spirit's hopes may like thy blossoms shine,

Bright at the last!

And as the grateful scent

Of thy meek flower, the memory of my name;

Oh! who could wish for prouder monument,

Or purer fame?

The darkness of the grave

Would wear no gloom appalling to the sight,

Might hope's fair blossom, like thy floweret, brave

Death's wintry night; 


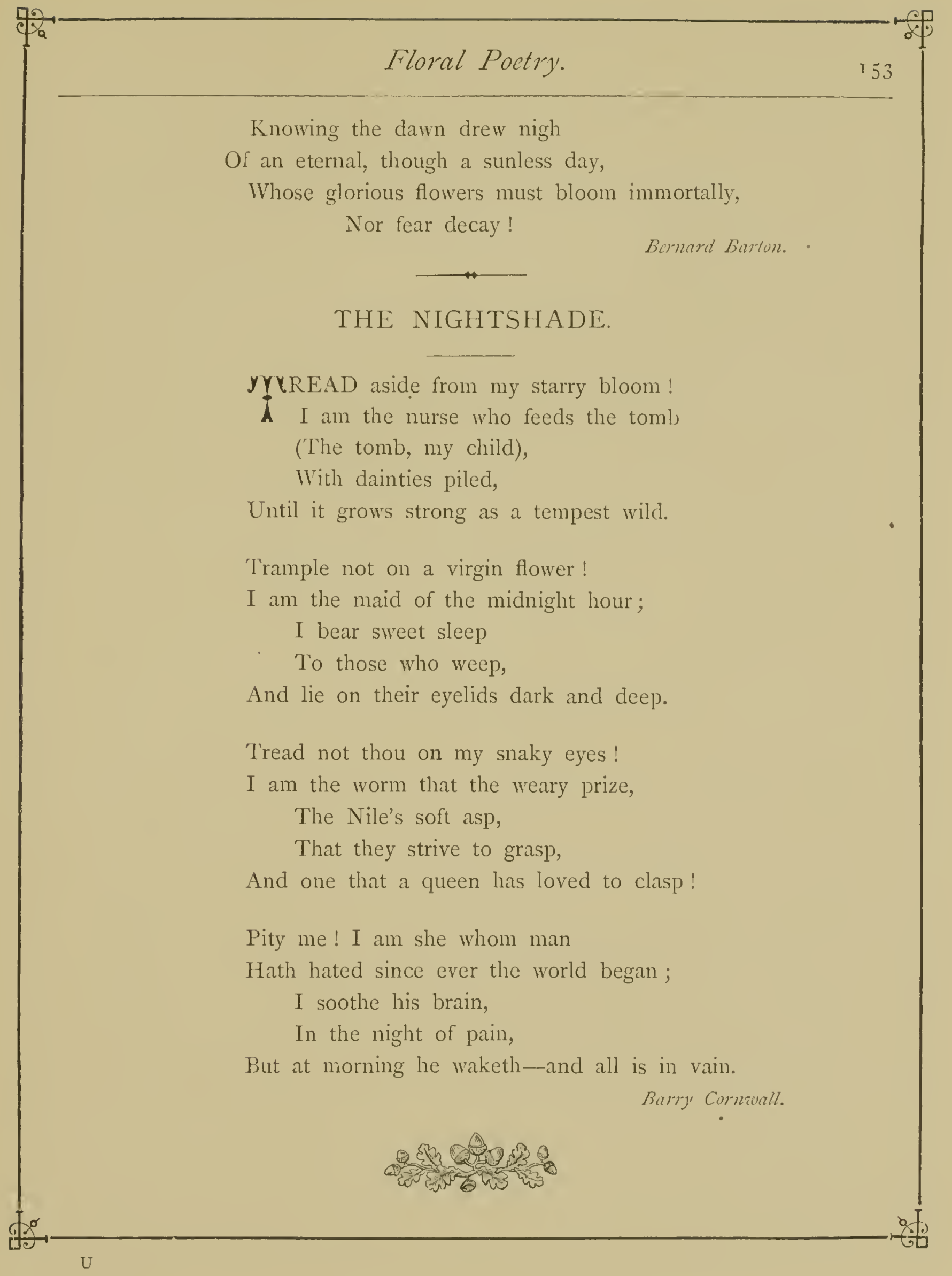




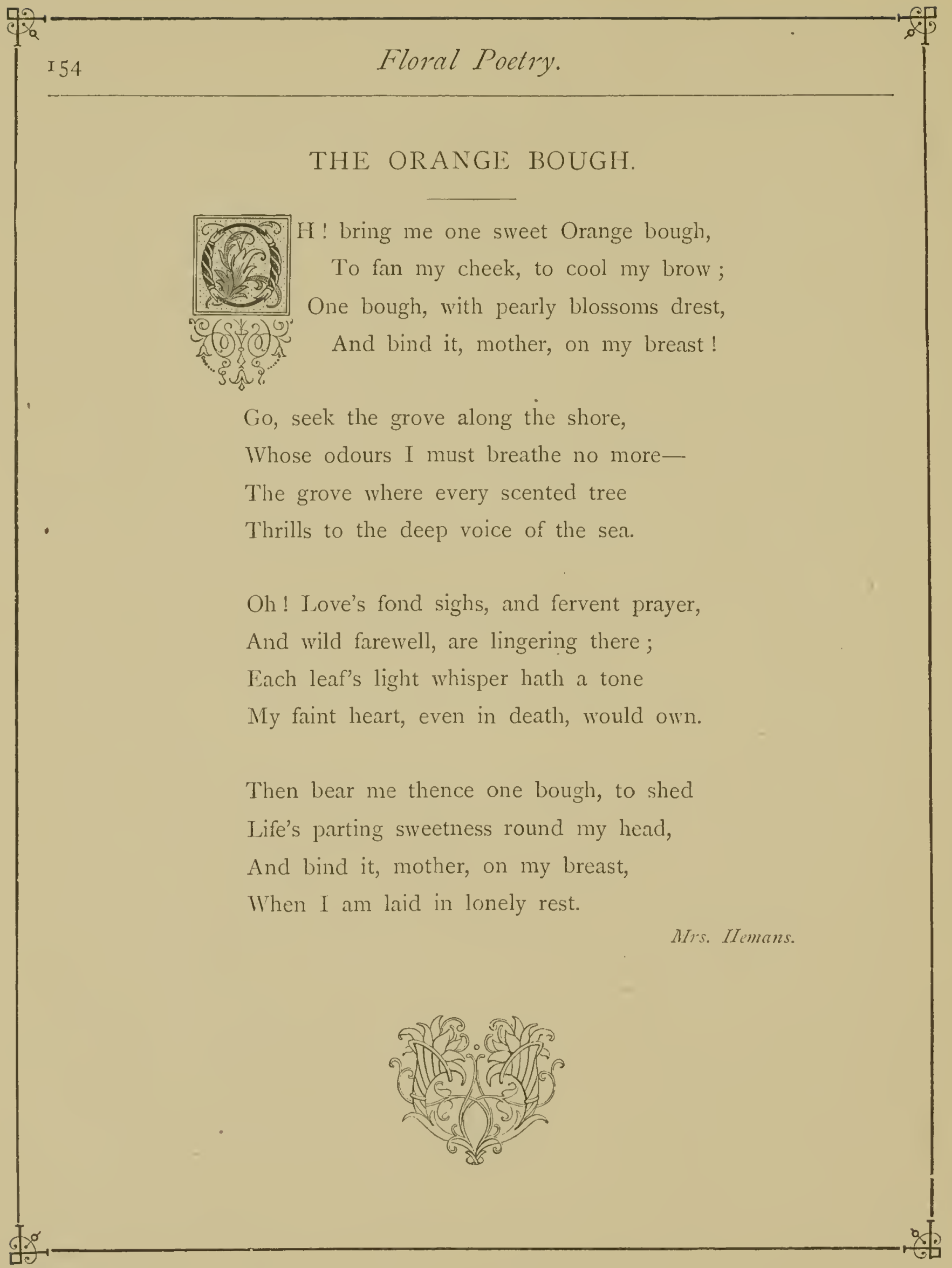




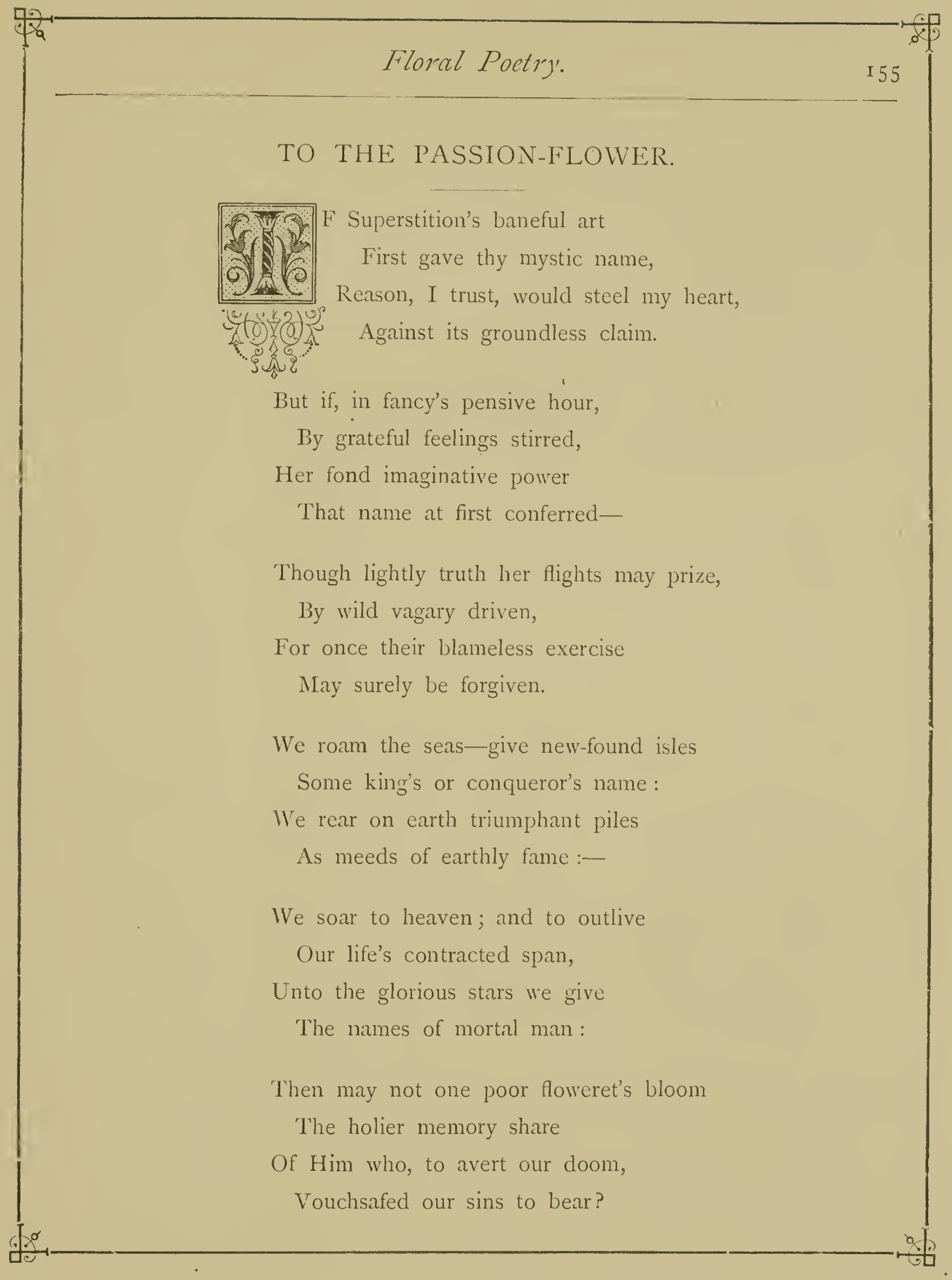


God dwelleth not in temples reared

By work of human hands,

Yet shrines august, by men revered,

Are found in Christian lands.

And may not e'en a simple flower

Proclaim His glorious praise,

Whose fiat only had the power

Its form from earth to raise?

Then freely let thy blossom ope

Its beauties-to recall

A scene which bids the humble hope

In Him who died for all !

Fernard Barton.

\section{PRIDE AND THE POPPIES.}

"YE little Red-caps are among the Corn,

Merrily dancing at early morn;

We know that the Farmer hates to see

Our saucy red faces, but here are we!

"We pay no price for our Summer coats,

Like those slavish creatures, Barley and Oats;

We don't choose to be ground and eat

Like our heavy-head neighbour, Gaffer Wheat.

"Who dare thrash Us, we should like to know?

Grind us, and bag us, and use us so?

Let meaner and shabbier things than we

So stupidly bend to utility!" 


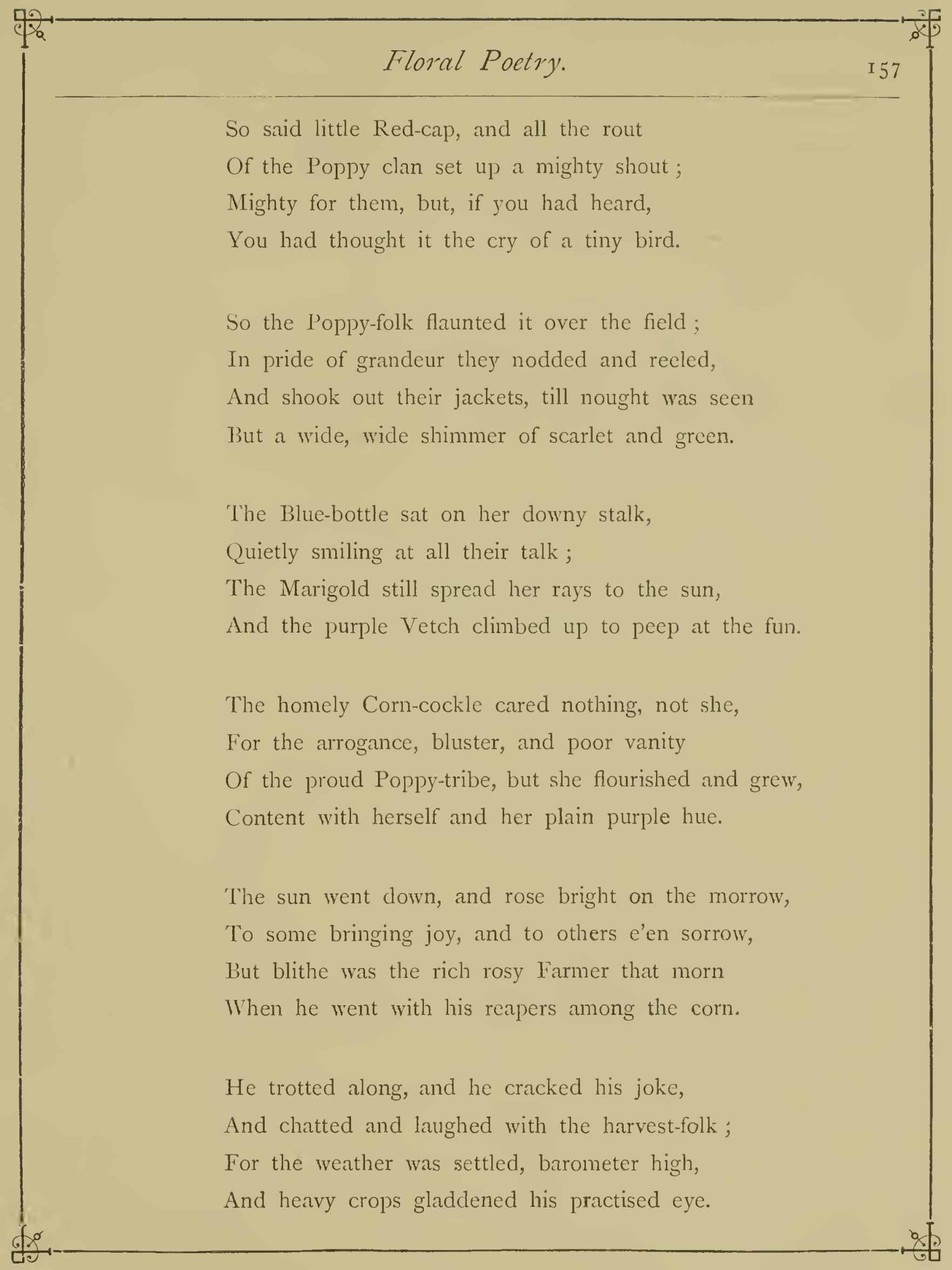


"We'll cut this Barley to-day," quoth he, As he tied his white pony under a tree, "Next the upland Wheat, and then the Oats;" How the Poppies shook in their scarlet coats!

Ay, shook with laughter, not fear, for they Never dreamed they too should be swept away, And their laughter was spite, to think that all Their "useful" neighbours were doomed to fall.

They swelled and bustled with such an air, The corn-fields quite in commotion were, And the Farmer cried, glancing across the grain, "How these rascally weeds have come up again!"

"Ha! ha!" laughed the Red-caps, "Ha! ha! what a fuss Must the poor weeds be in! how they're envying us!" But their mirth was cut short by the sturdy strokes They speedily met from the harvest-folks.

And when low on earth each stem was laid, And the round moon looked on the havoc made, A Blue-bottle propped herself half erect, And made a short speech-to this effect:-

"My dying kins-flowers, and fainting friends, The same dire fate alike attends Those who in scarlet or blue are dressed, Then how silly the pride that so late possessed 


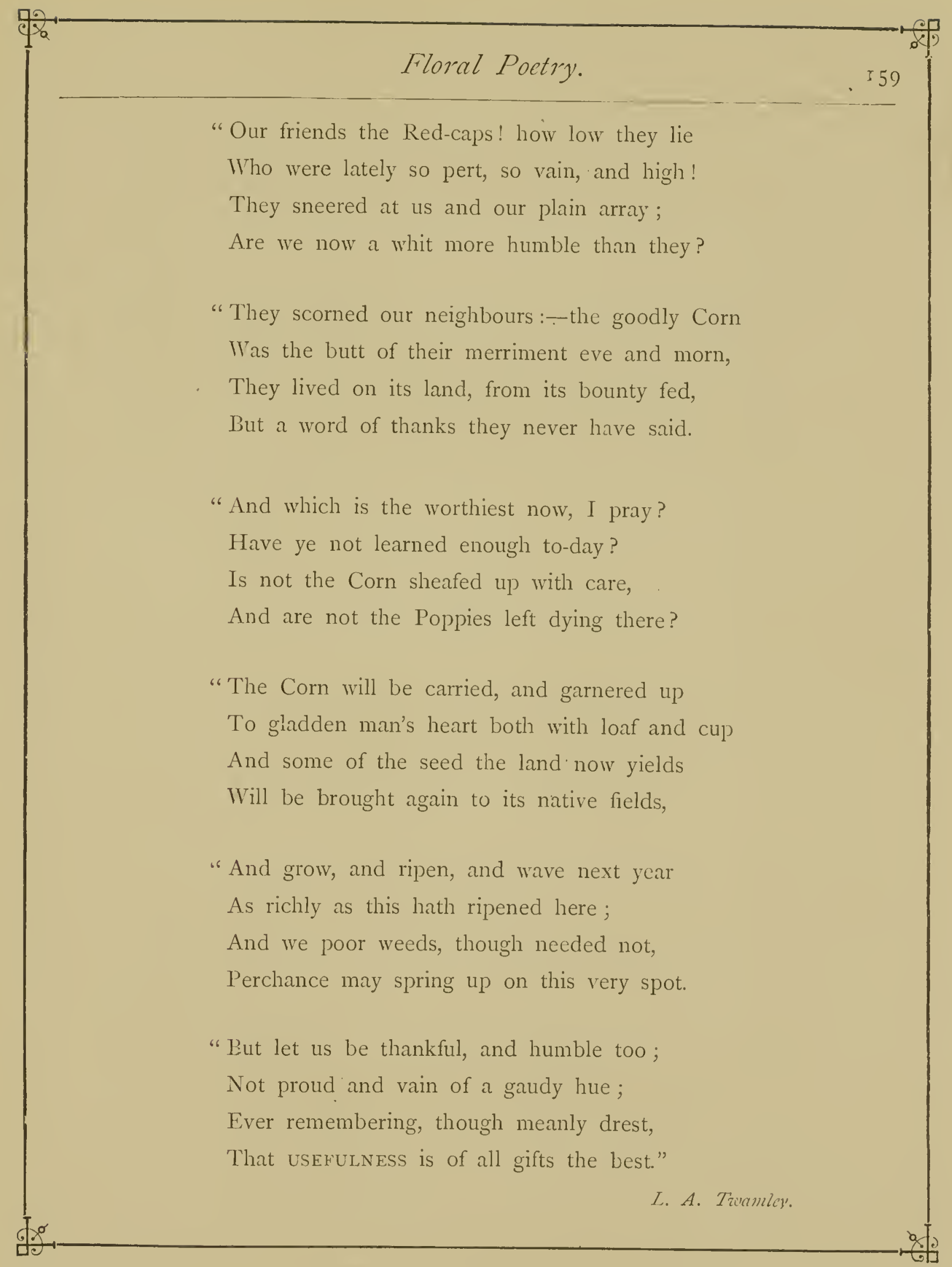




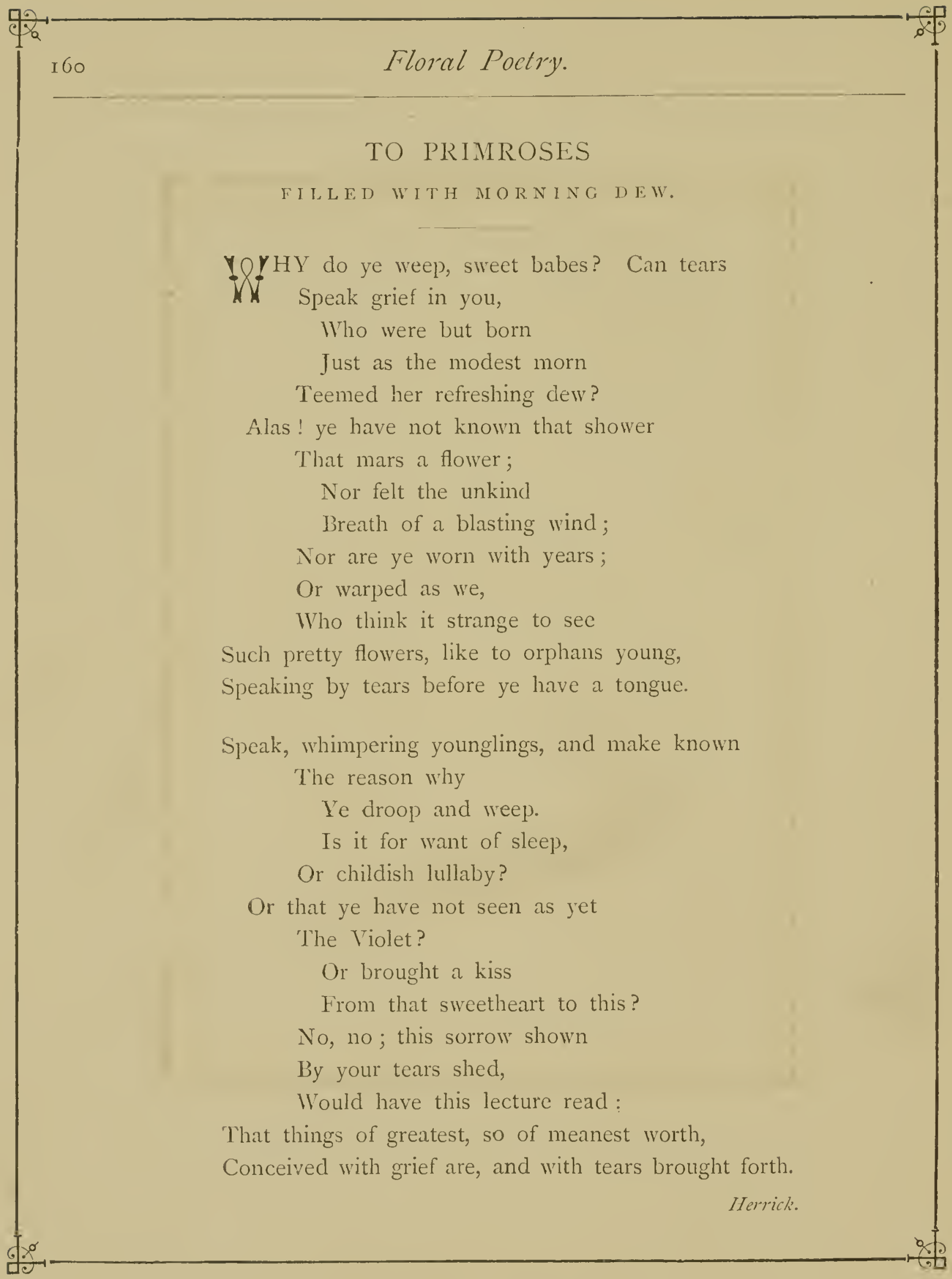




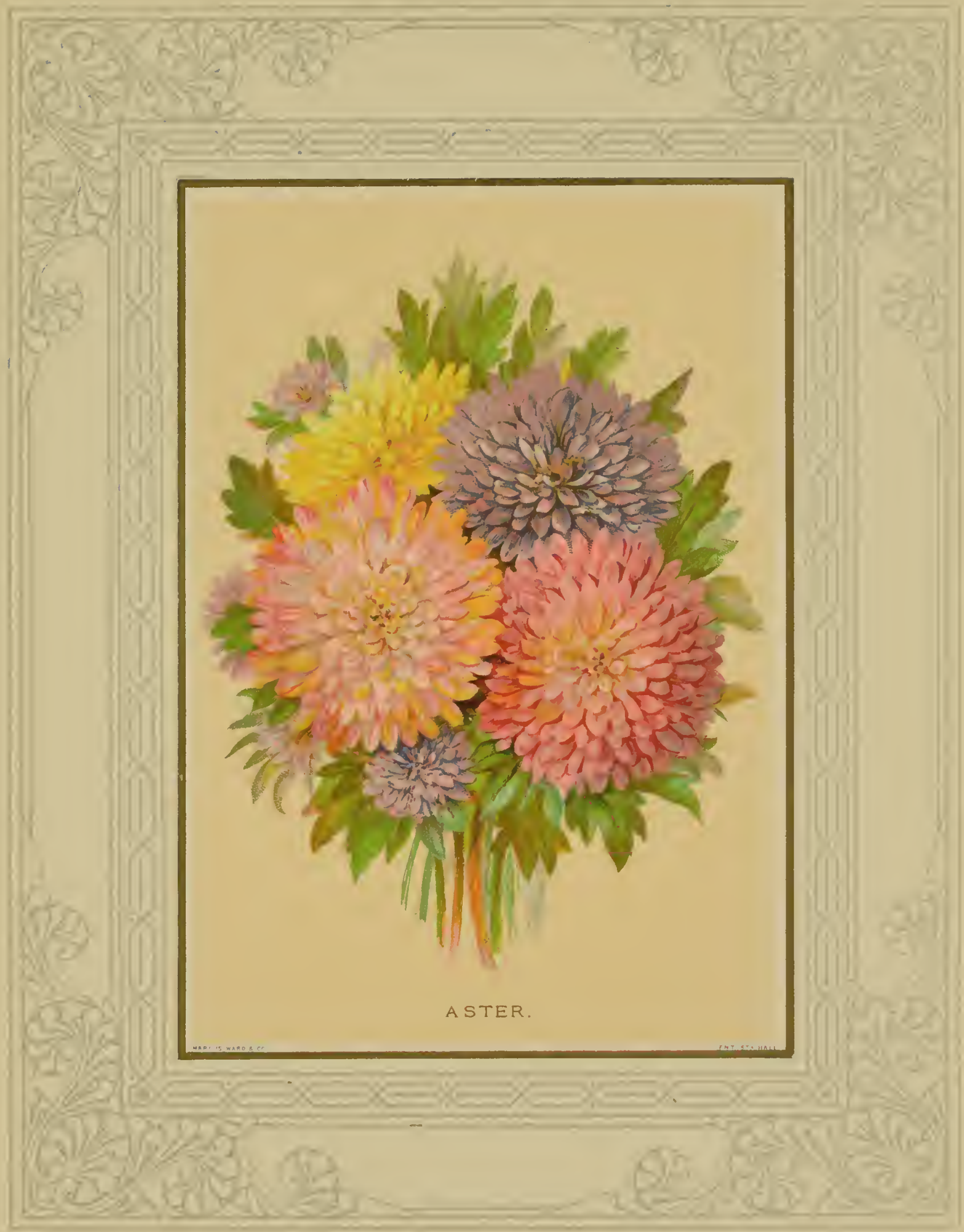


, 


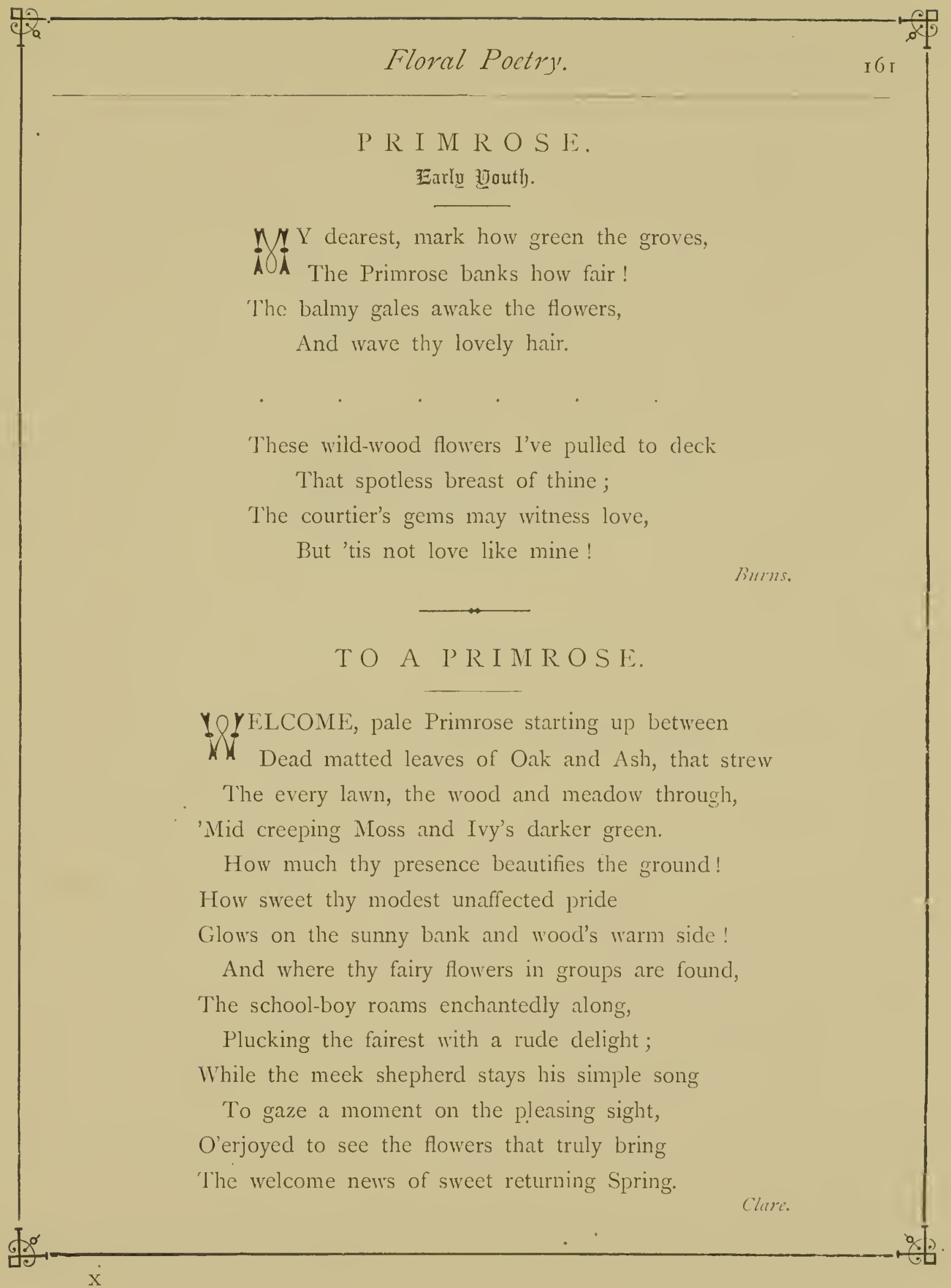




\section{TO AN EARLY PRIMROSE.}

ILD offspring of a dark and sullen sire!

IOI Whose modest form, so delicately fine,

Was nursed in whirling storms,

And cradled in the wind.

Thee, when young Spring first questioned Winter's sway,

And dared the sturdy blusterer to the fight-

Thee on this bank he threw,

To mark his victory.

In this low vale, the promise of the year,

Serene thou openest to the nipping gale,

Unnoticed and alone,

Thy tender elegance.

So virtue blooms, brought forth amid the storms

Of chill adversity, in some lone walk

Of life she rears her head,

Obscure and unobserved;

While every bleaching breeze that on her blows,

Chastens her spotless purity of breast,

And hardens her to bear

Serene the ills of life.

II. K. White. 


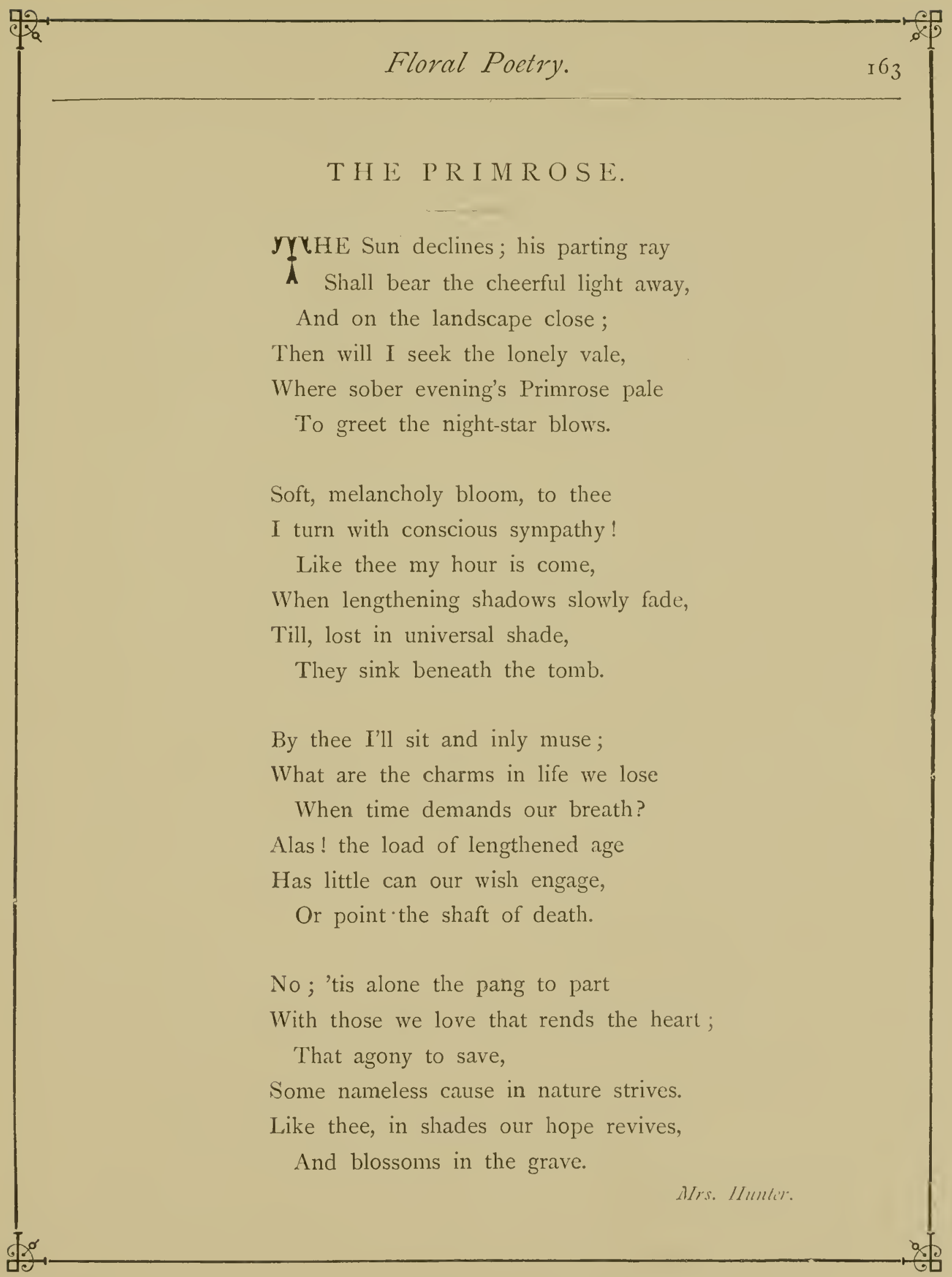




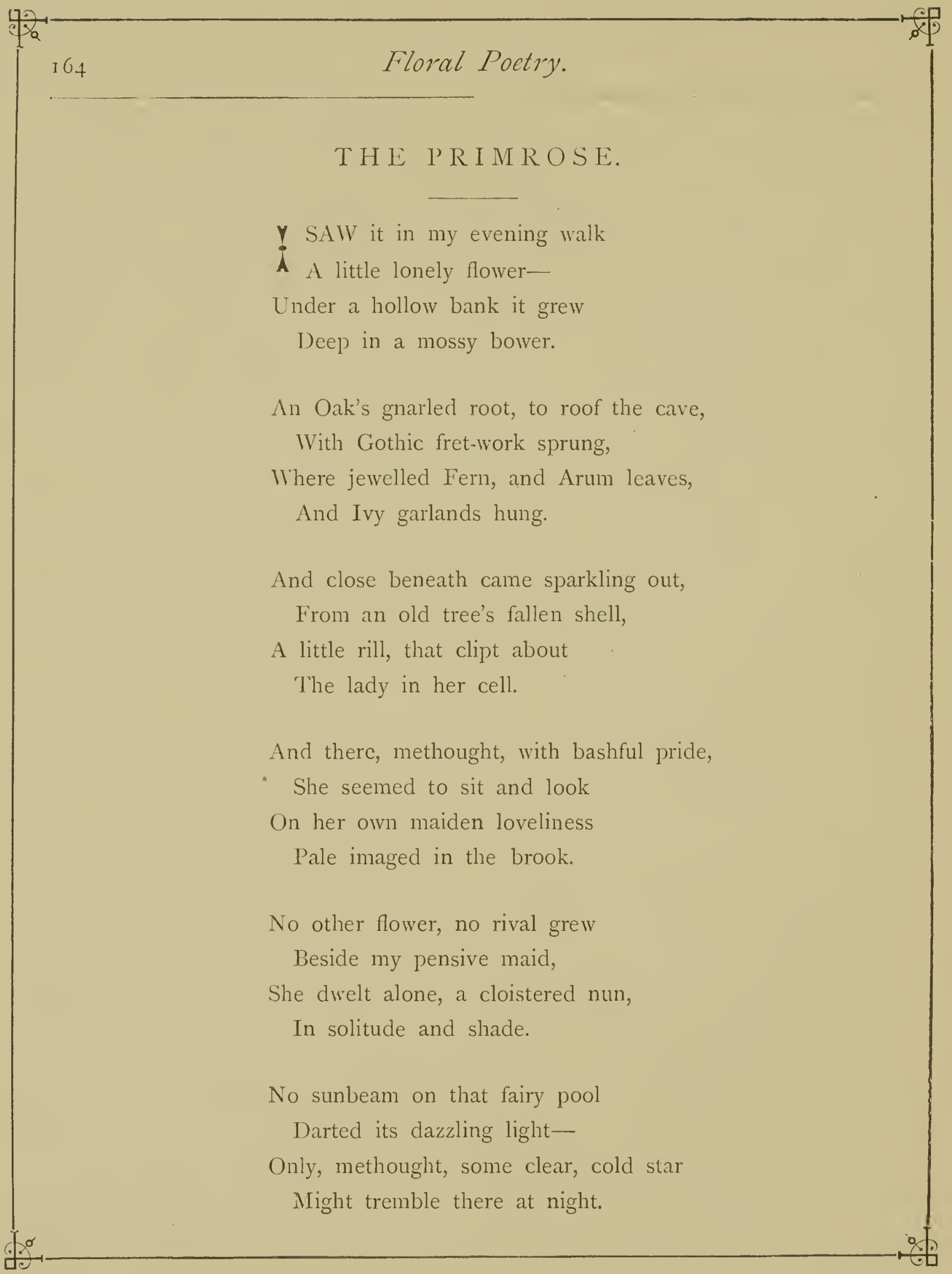




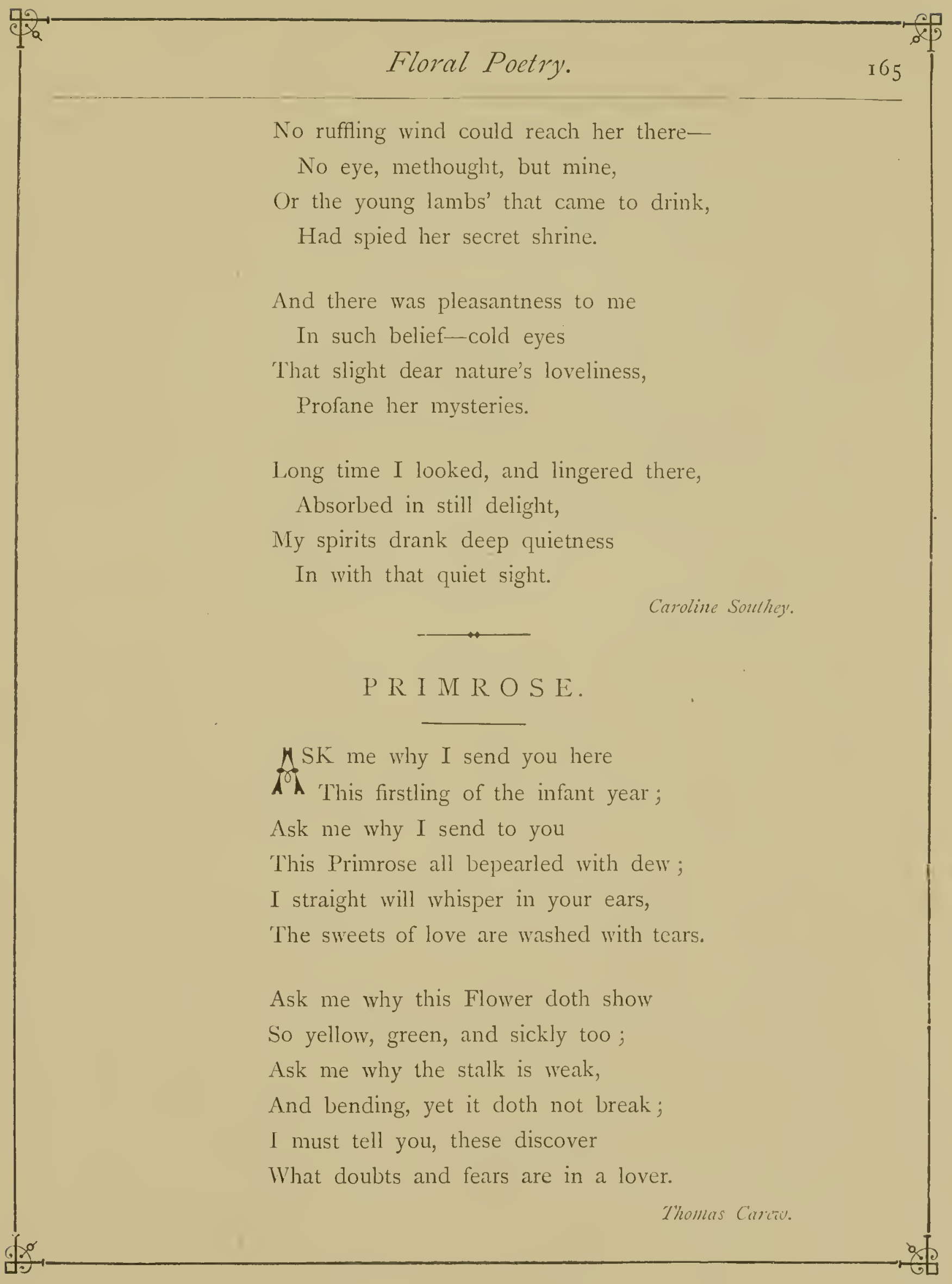




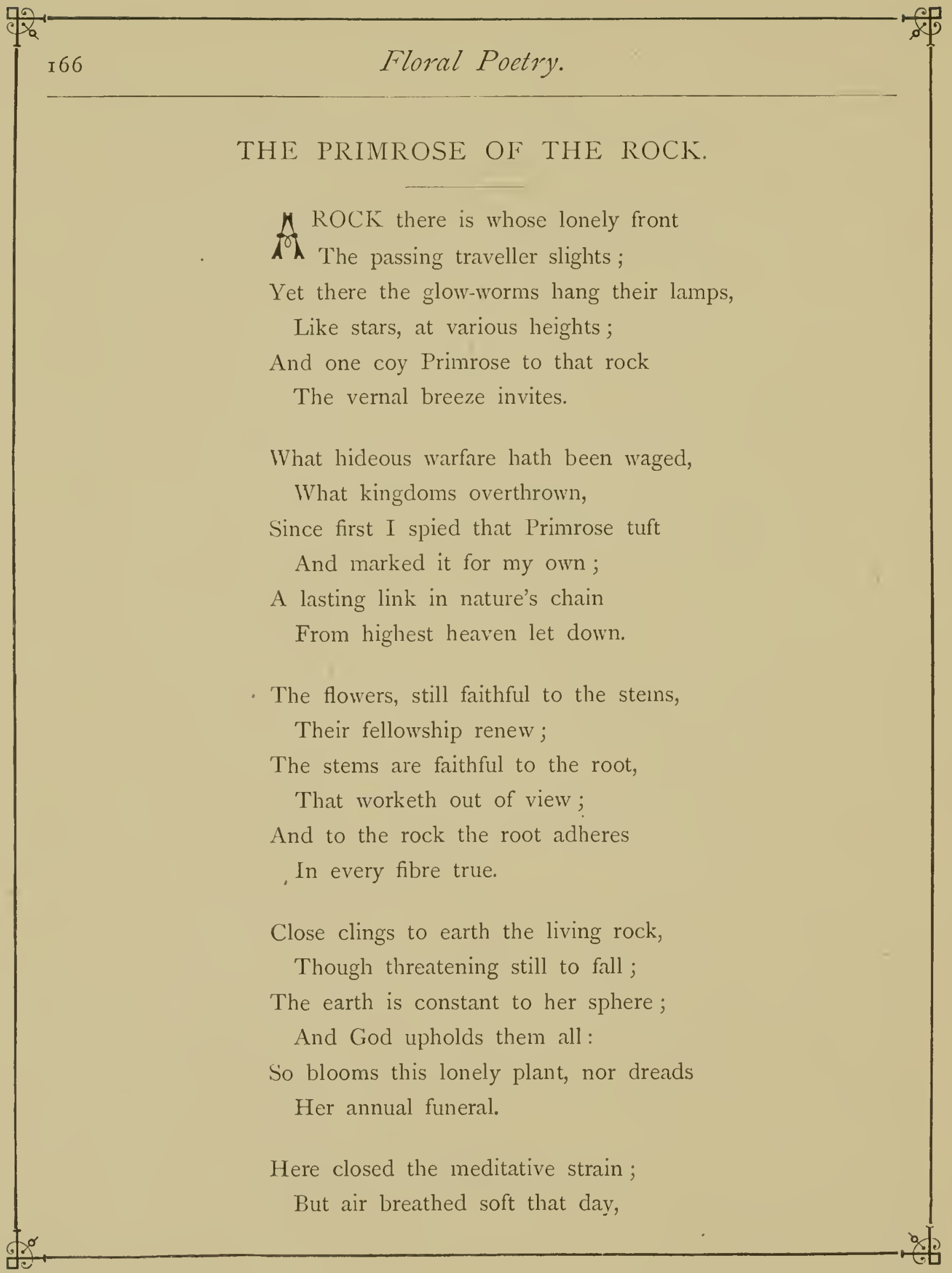




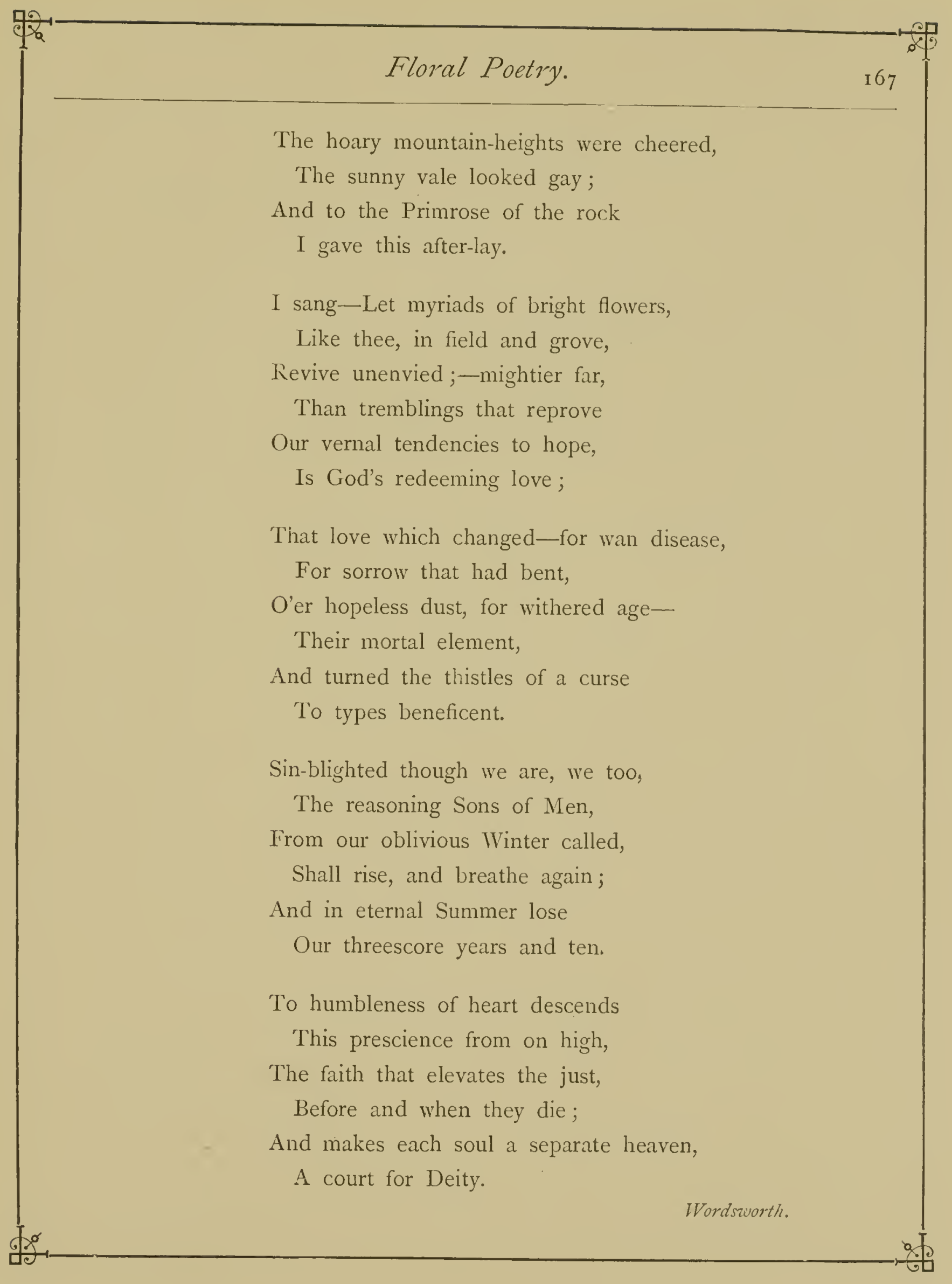




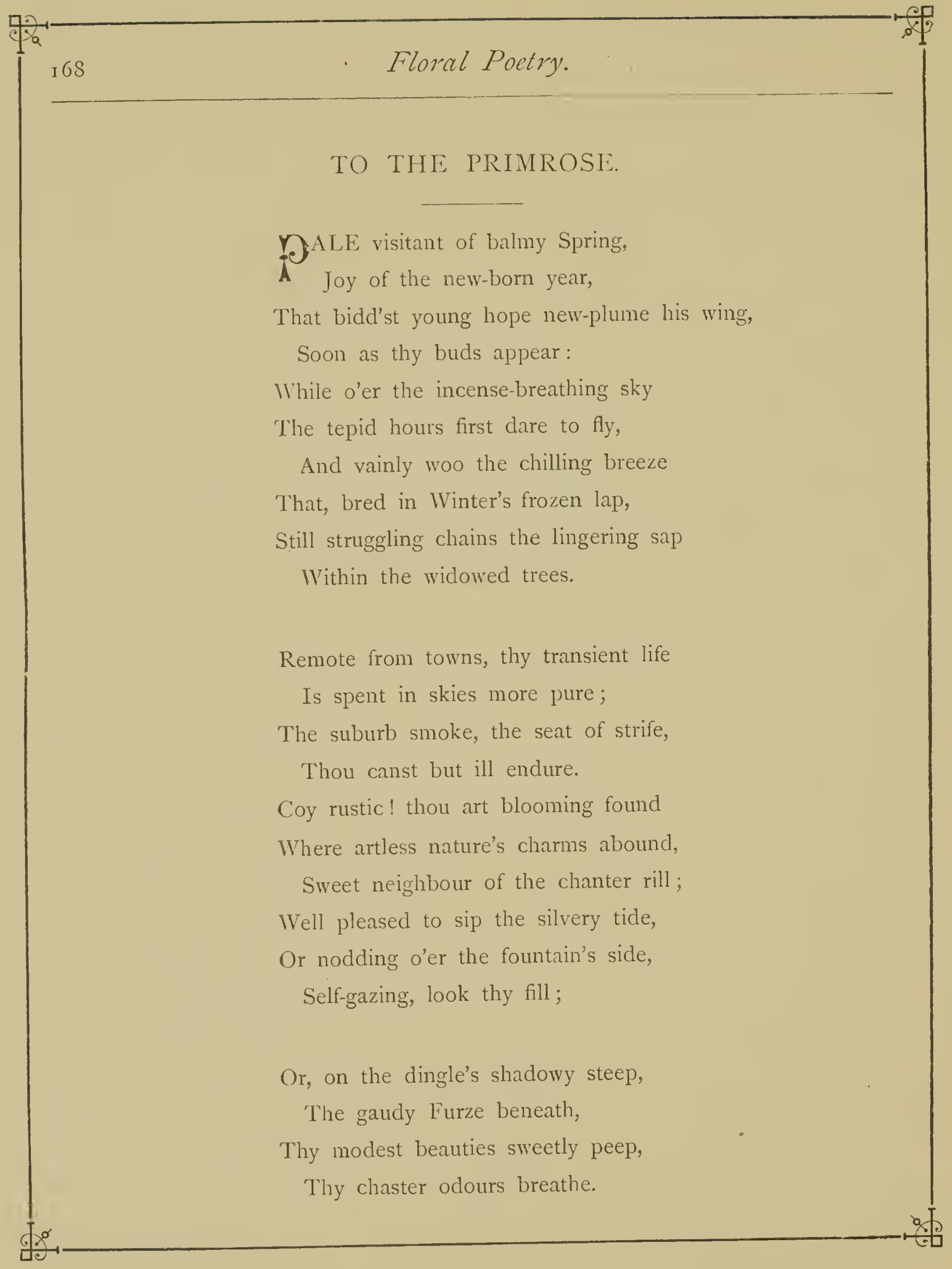




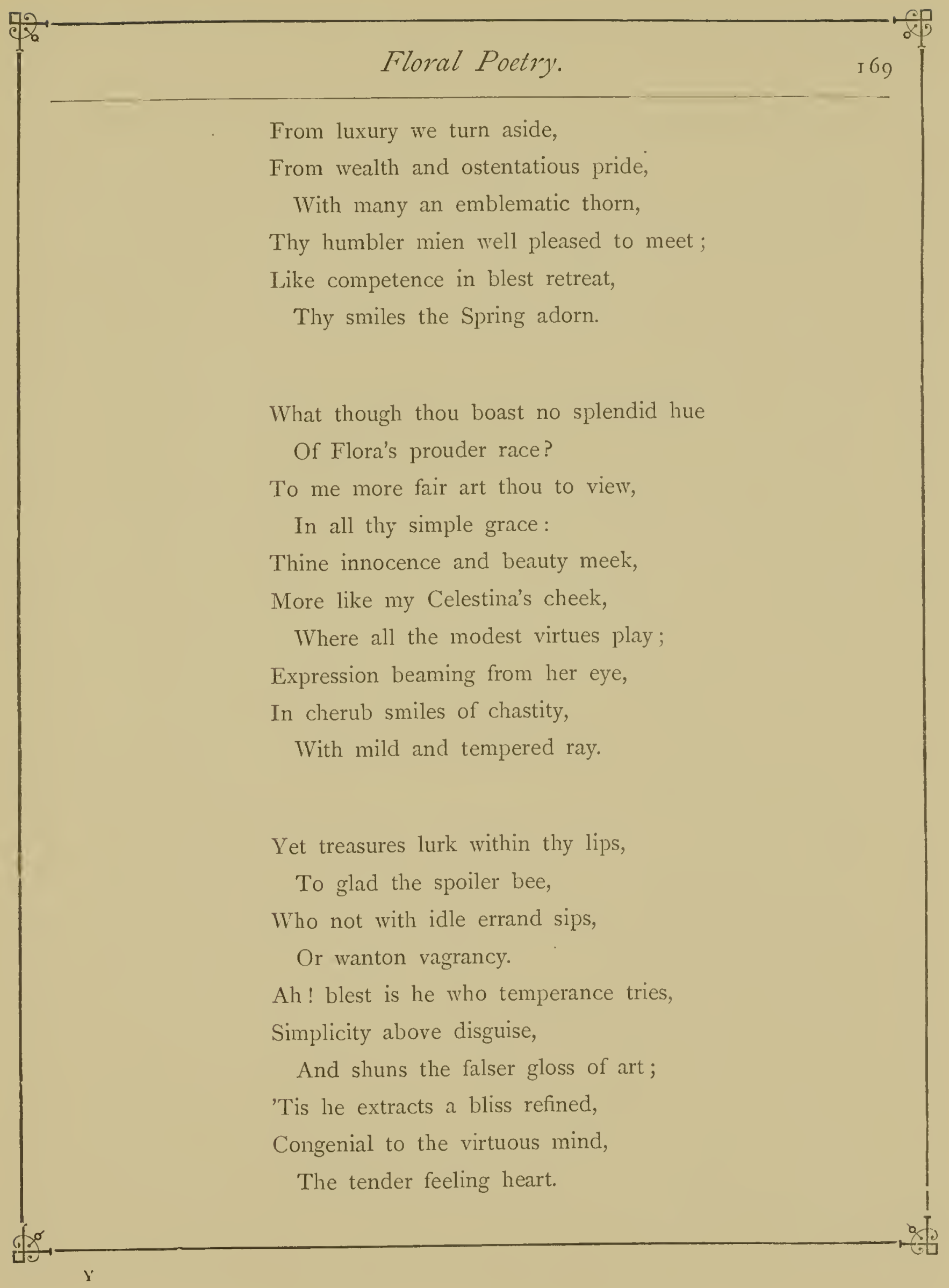




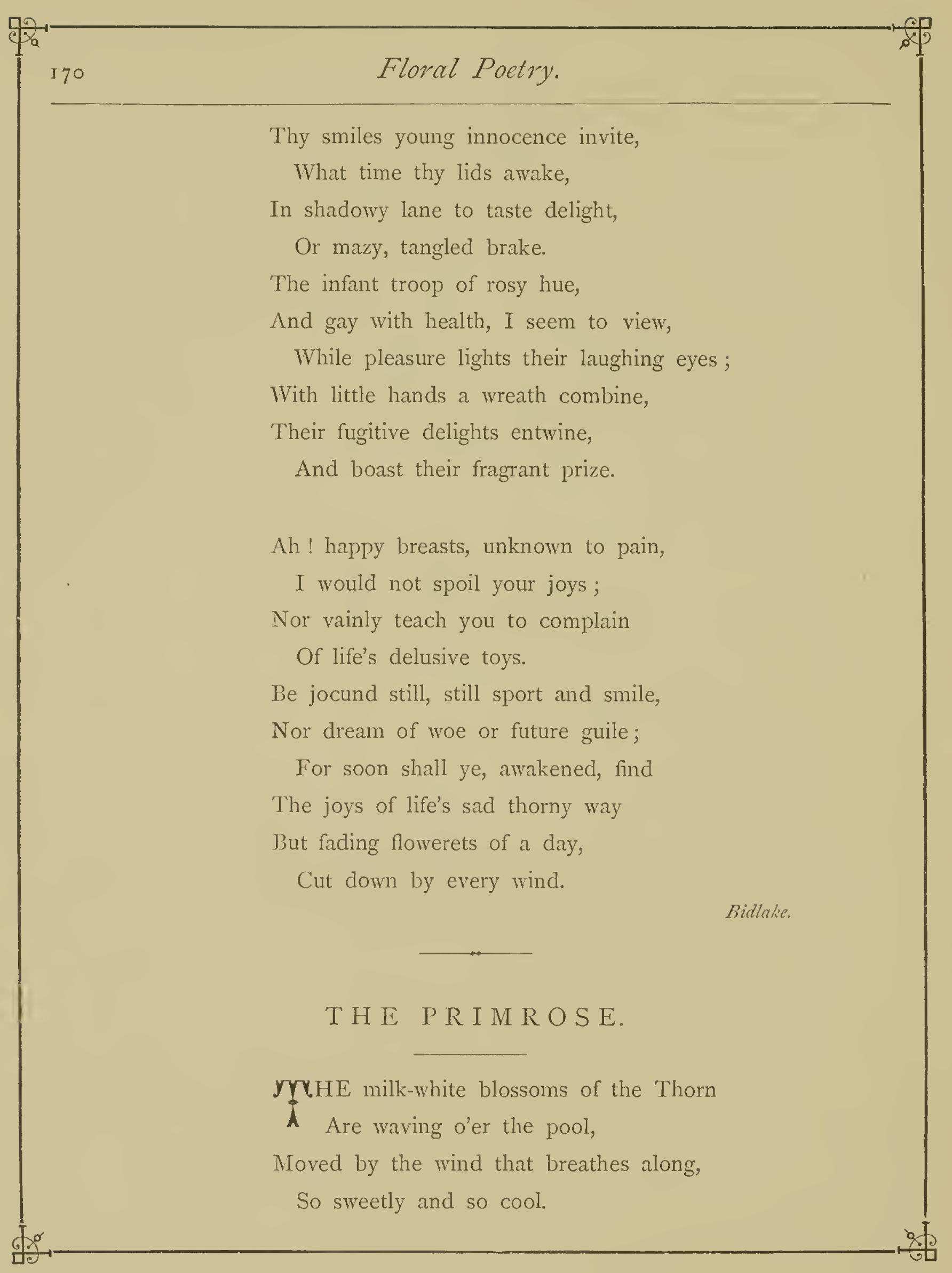




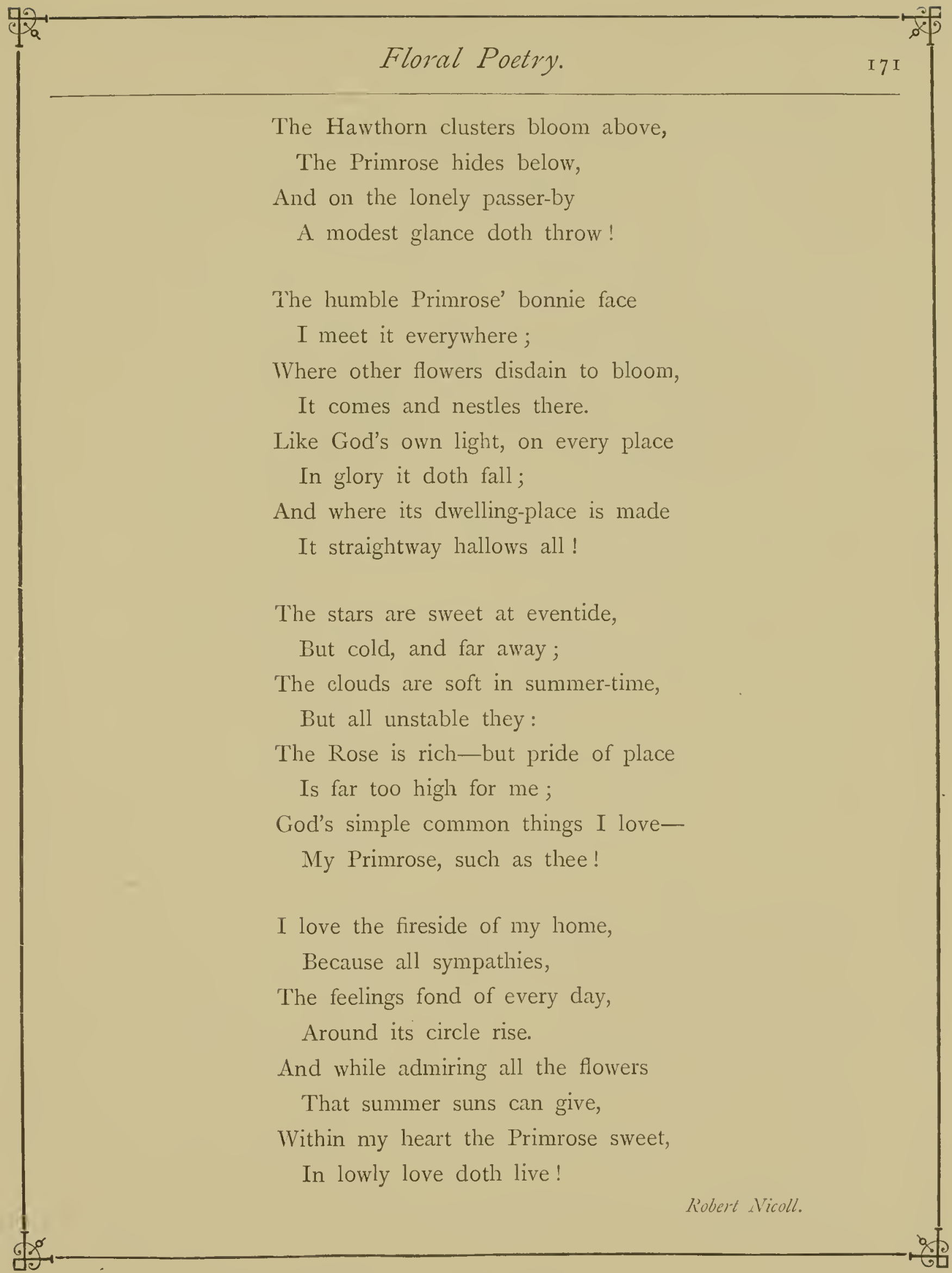




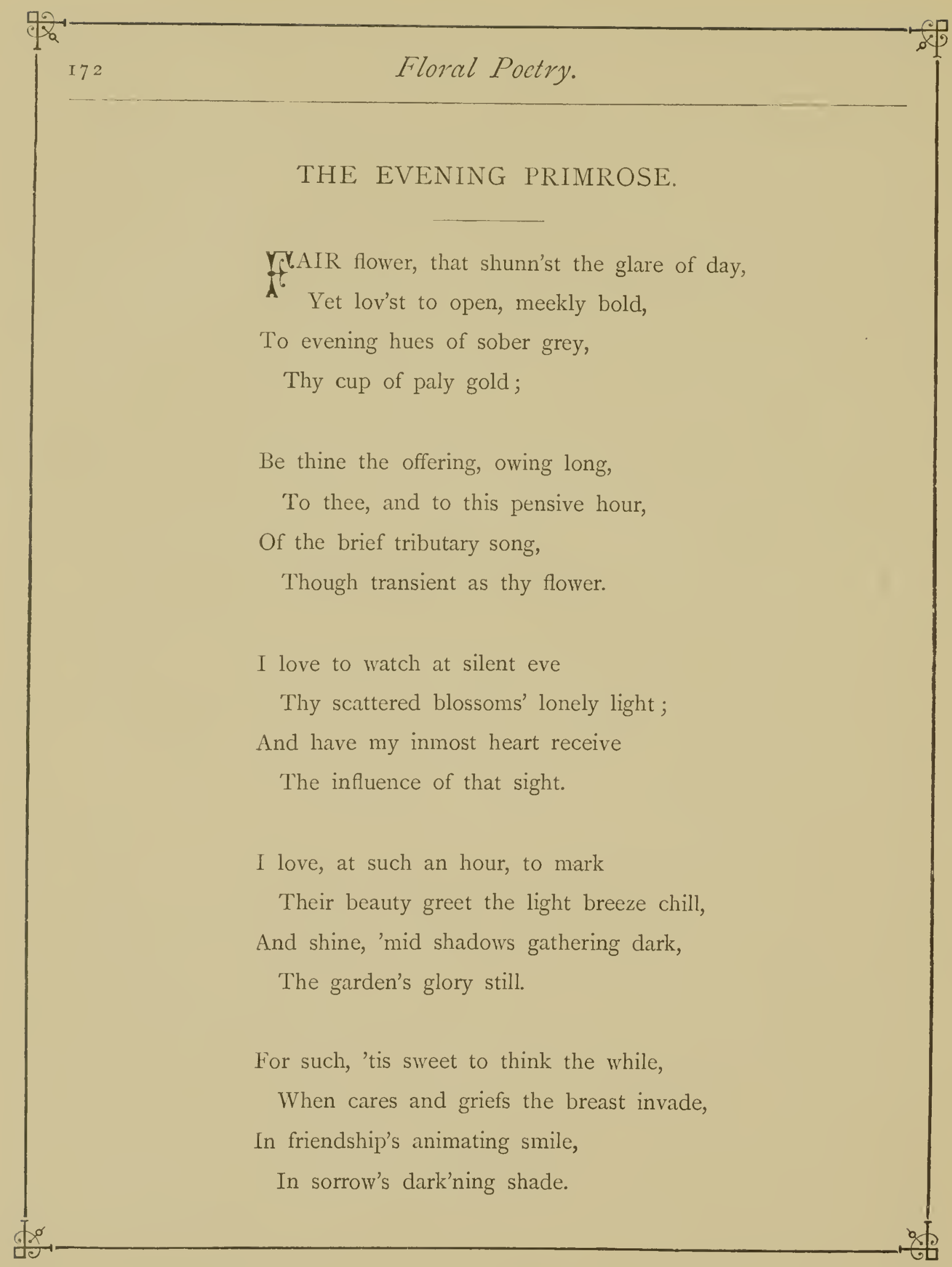




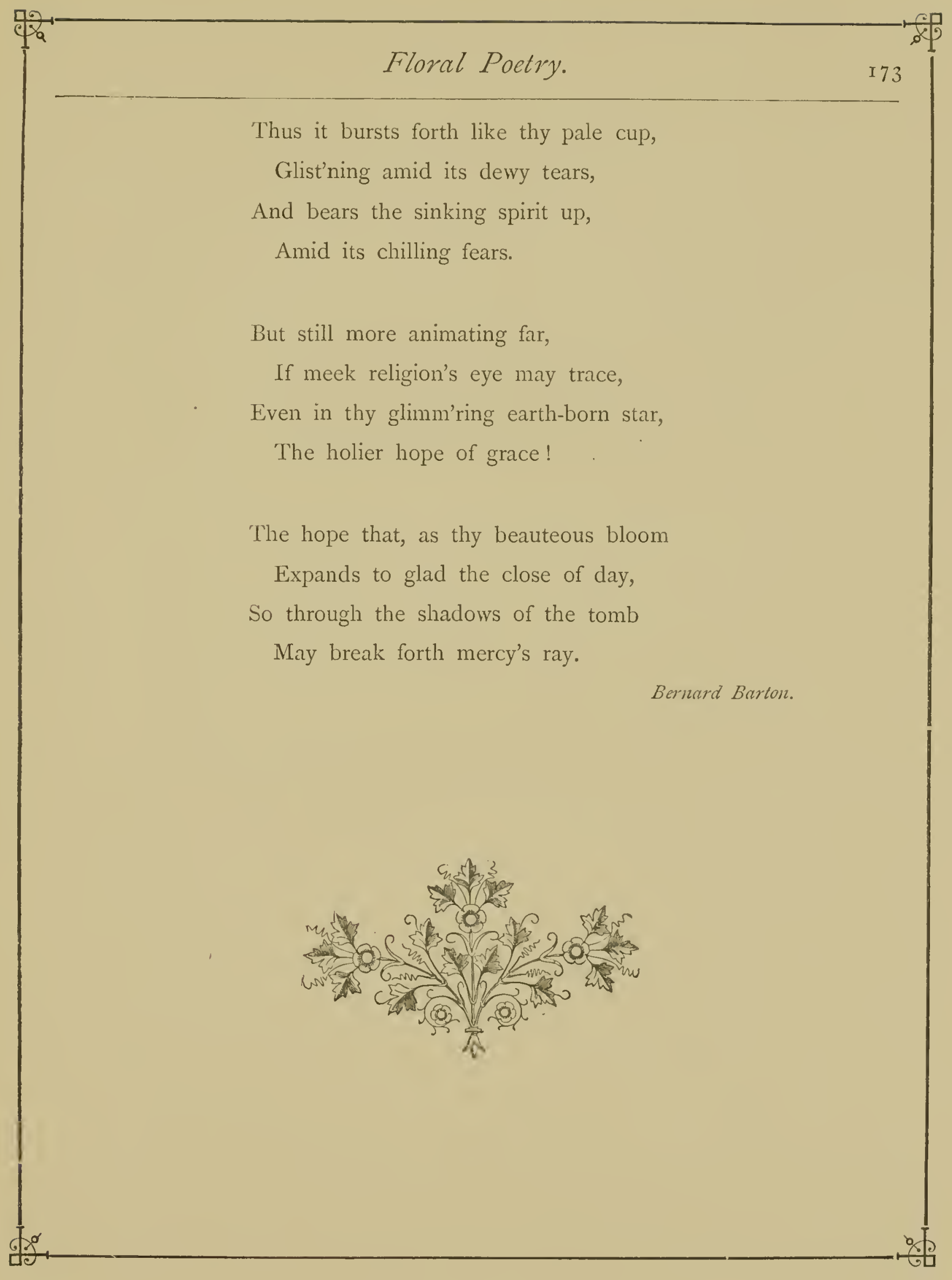




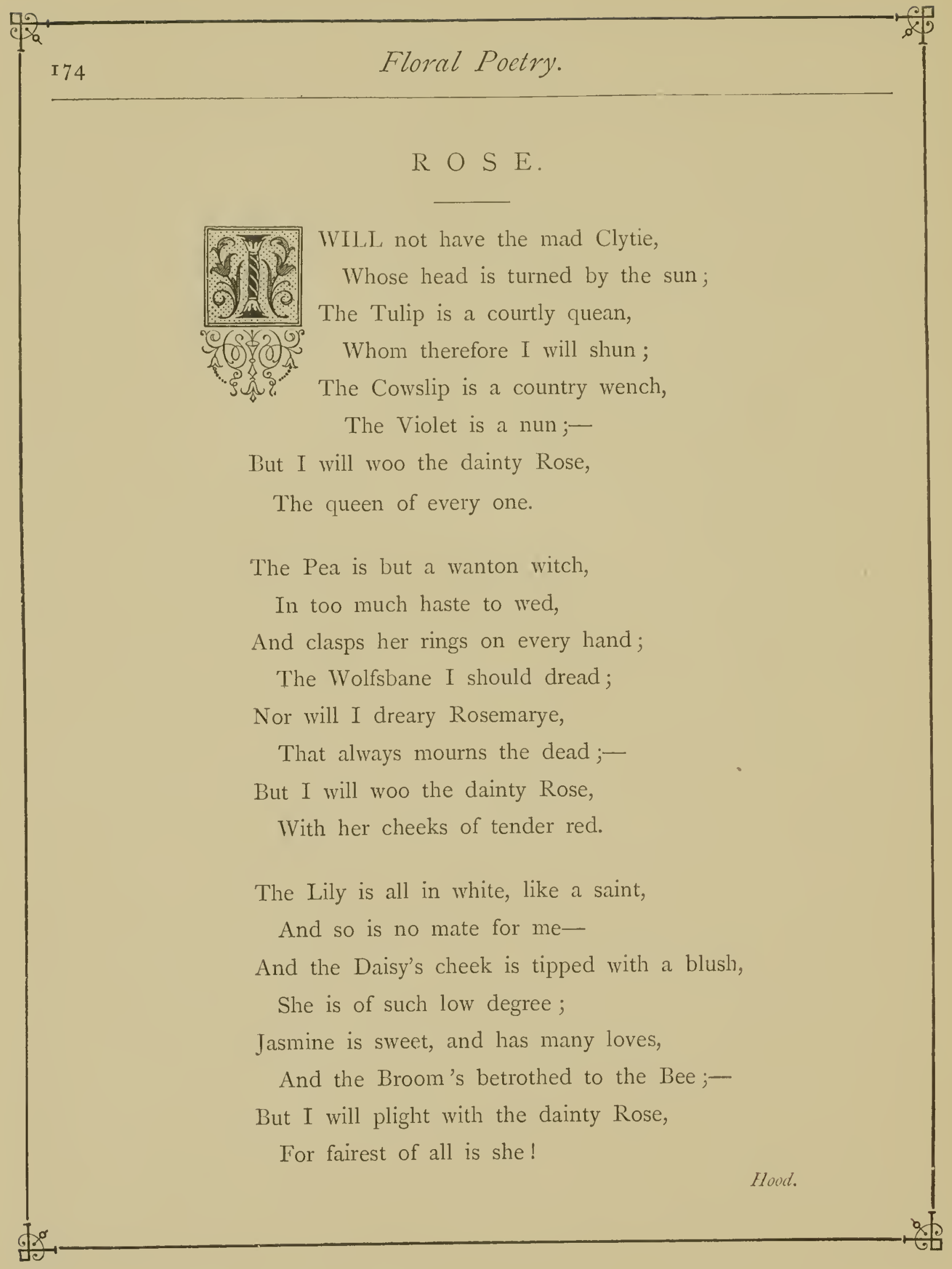




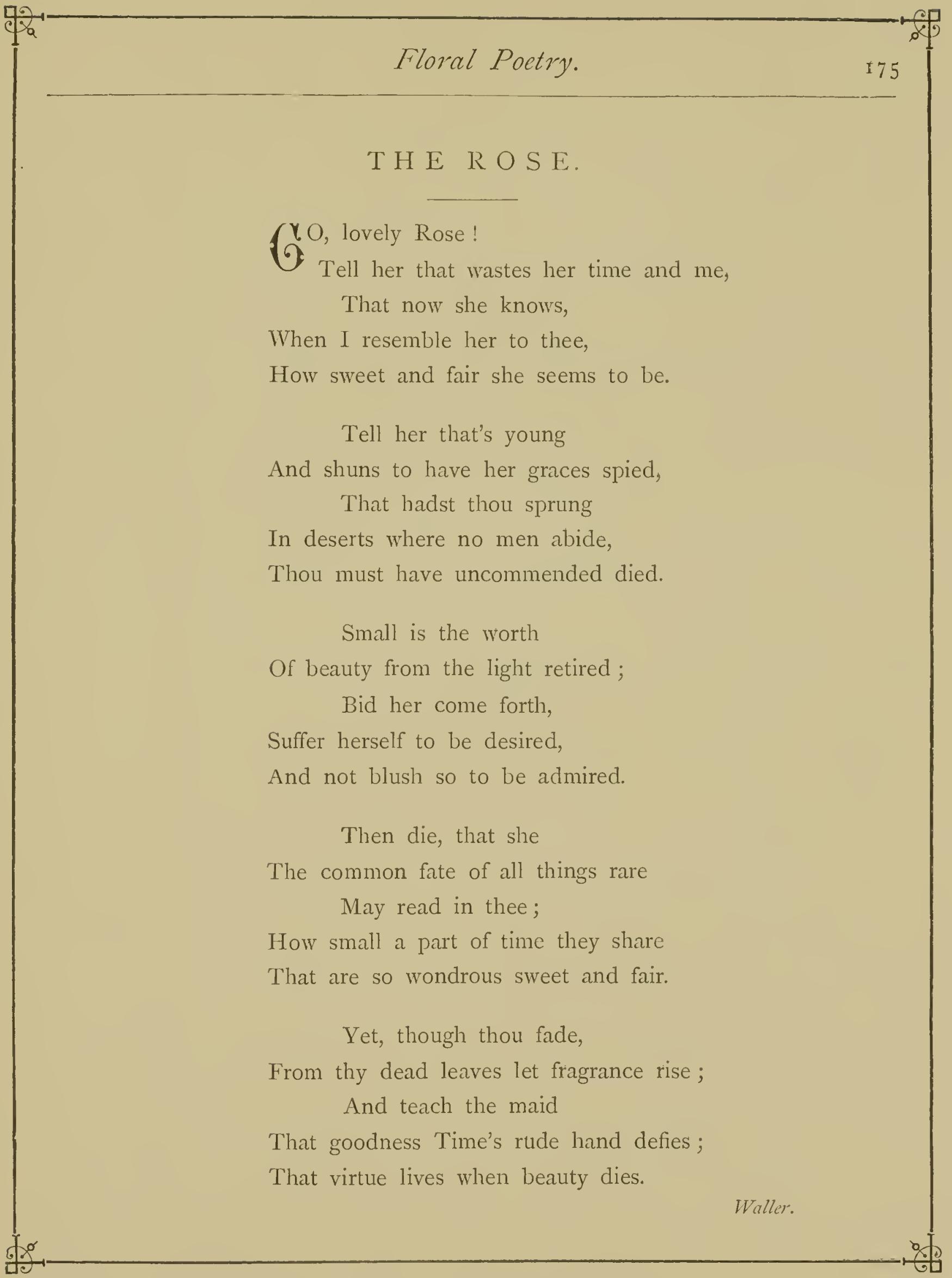




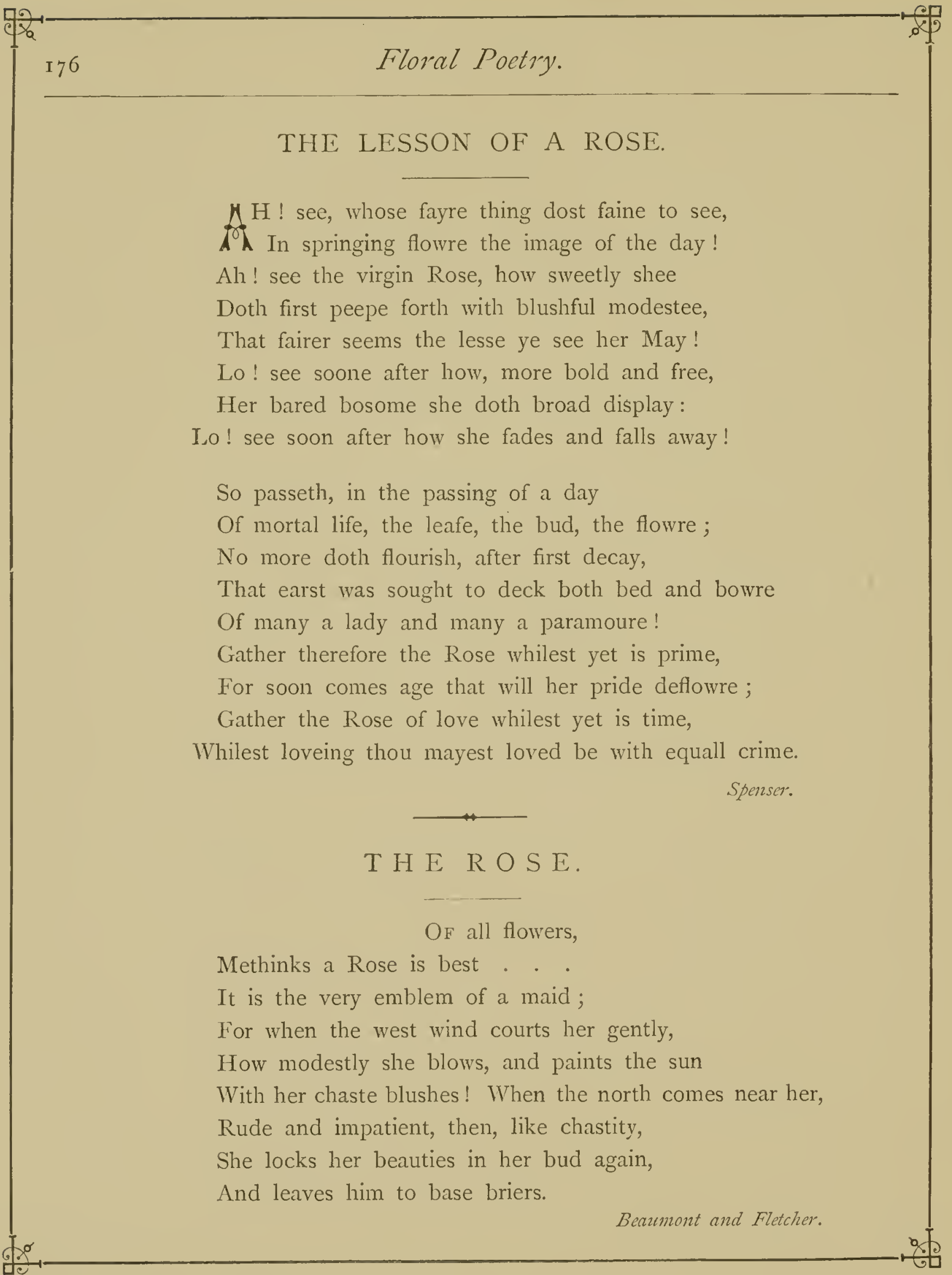




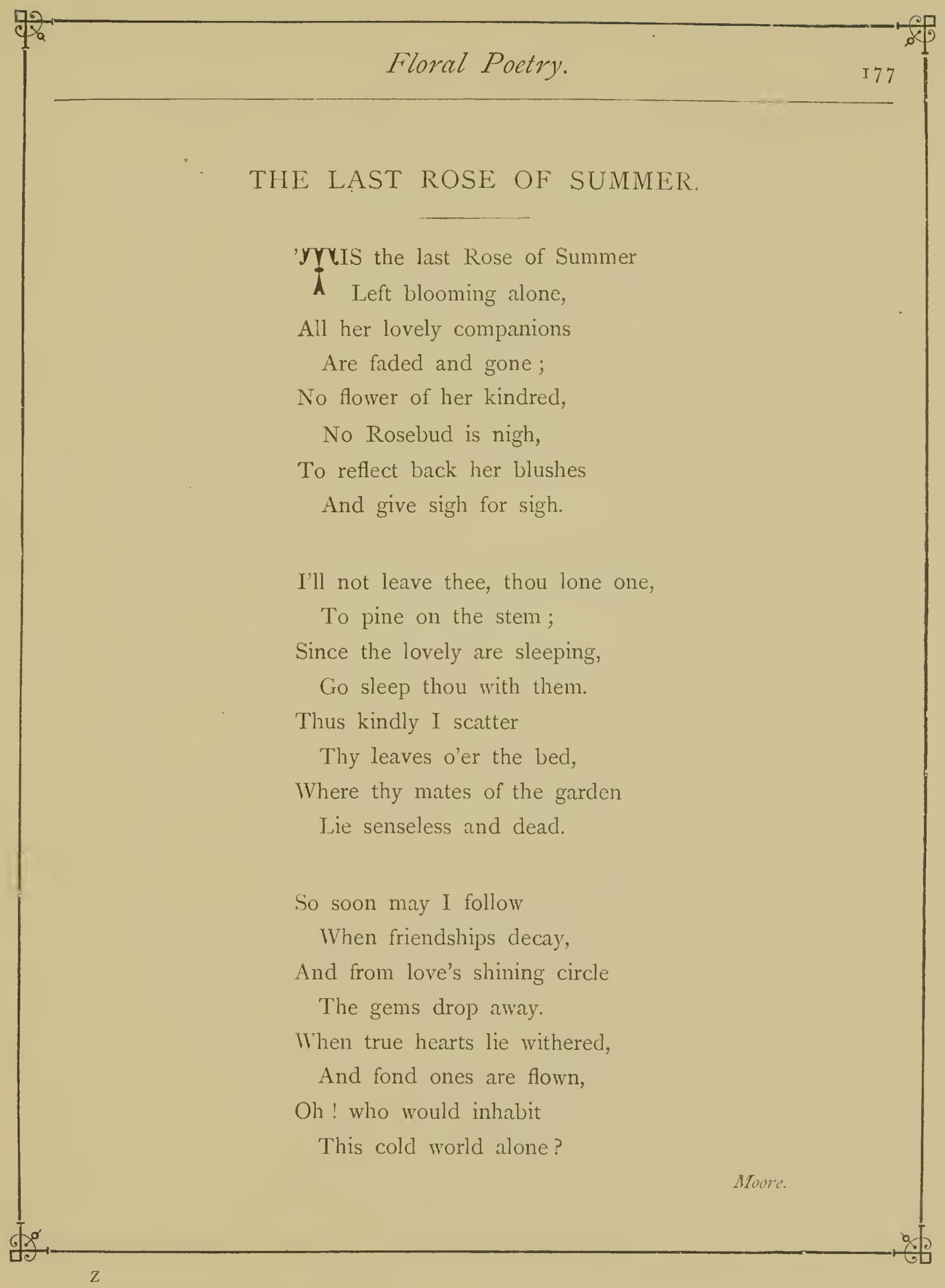




\section{THE ROSE S.}

Y SAIV them once blowing,

$\boldsymbol{\lambda}$ While morning was glowing;

But now are their withered leaves strewed o'er the ground,

For tempests to play on,

For cold worms to prey on,

The shame of the garden that triumphs around.

Their buds which then flourished,

With dew-drops were nourished,

Which turned into pearls as they fell from on high;

Their hues are all banished,

Their fragrance all vanished,

Ere evening a shadow has cast from the sky.

I saw, too, whole races

Of glories and graces

Thus open and blossom, but quickly decay;

And smiling and gladness,

In sorrow and sadness,

Ere life reached its twilight, fade dimly away.

Joy's light-hearted dances,

And melody's glances,

Are rays of a moment-are dying when born;

And pleasure's best dower

Is nought but a flower,

A vanishing dew-drop-a gem of the morn. 


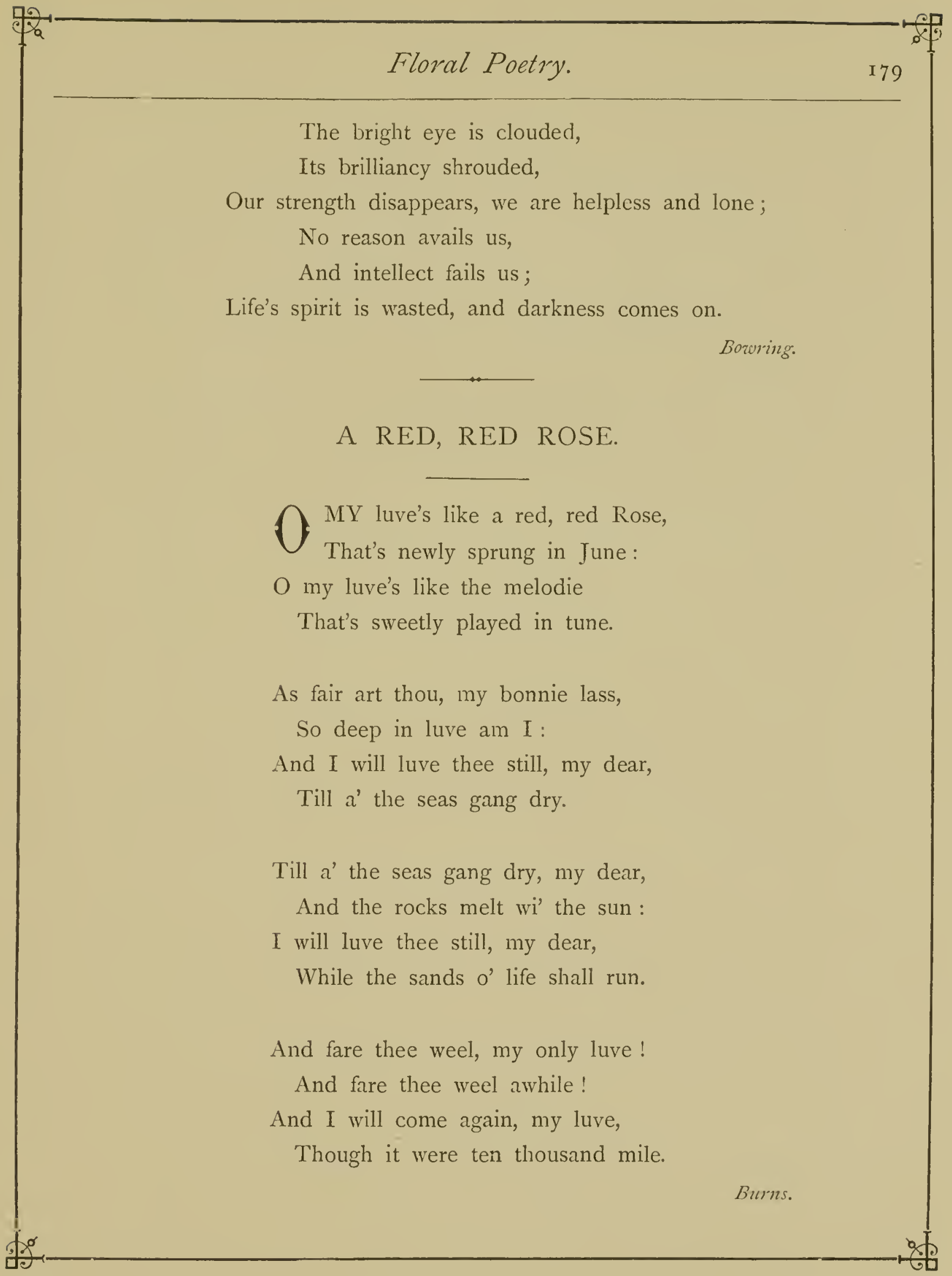




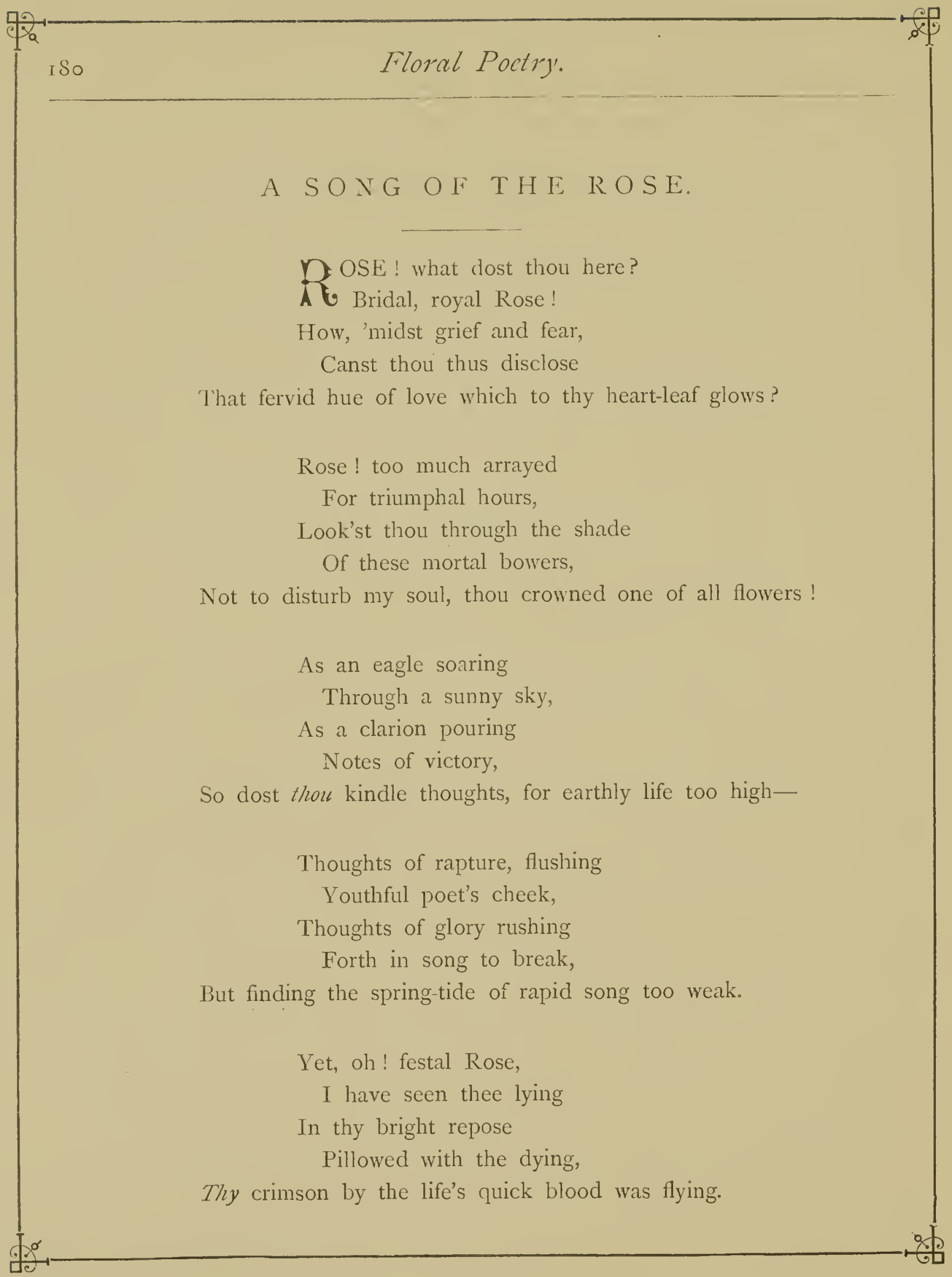




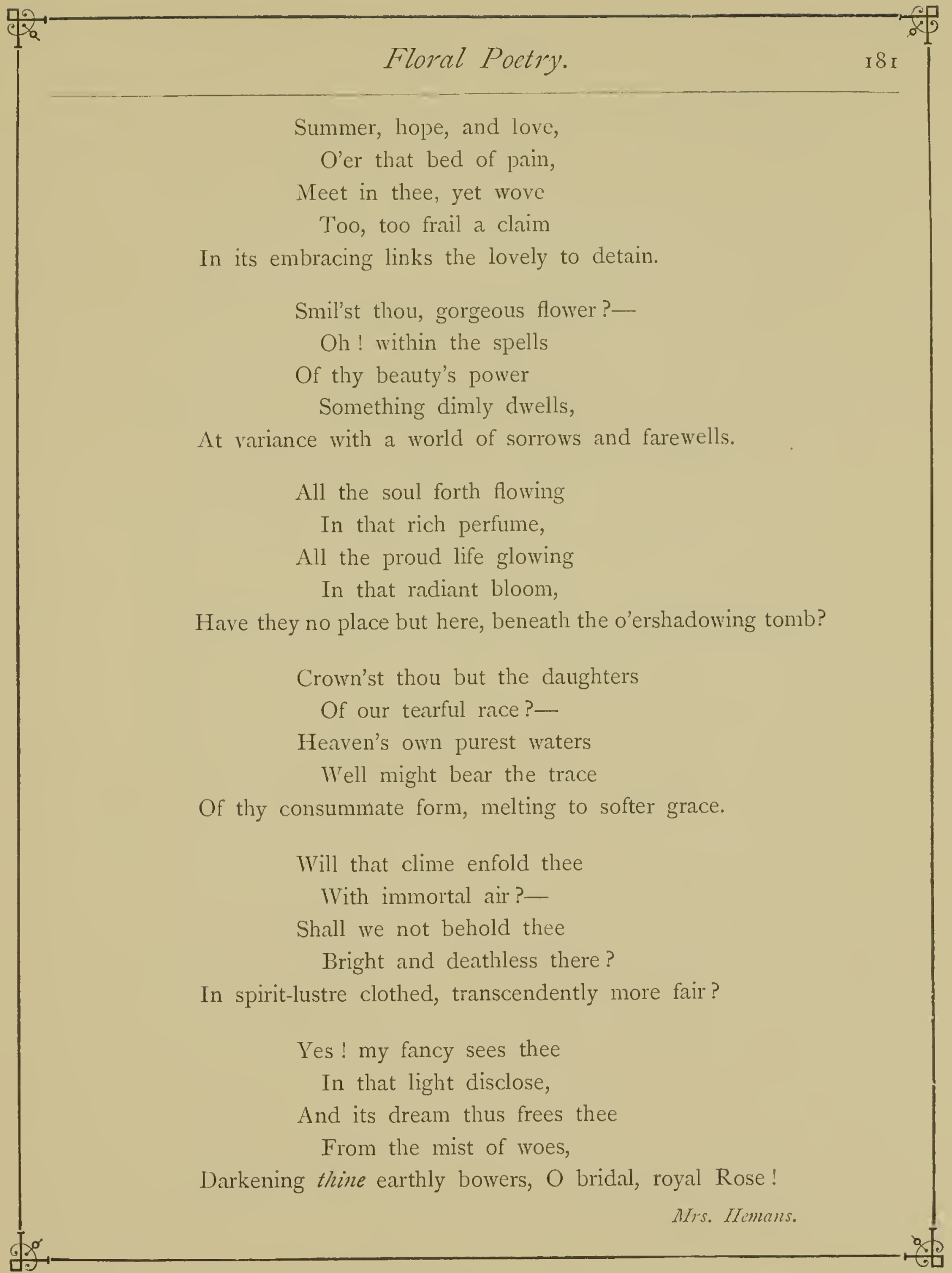




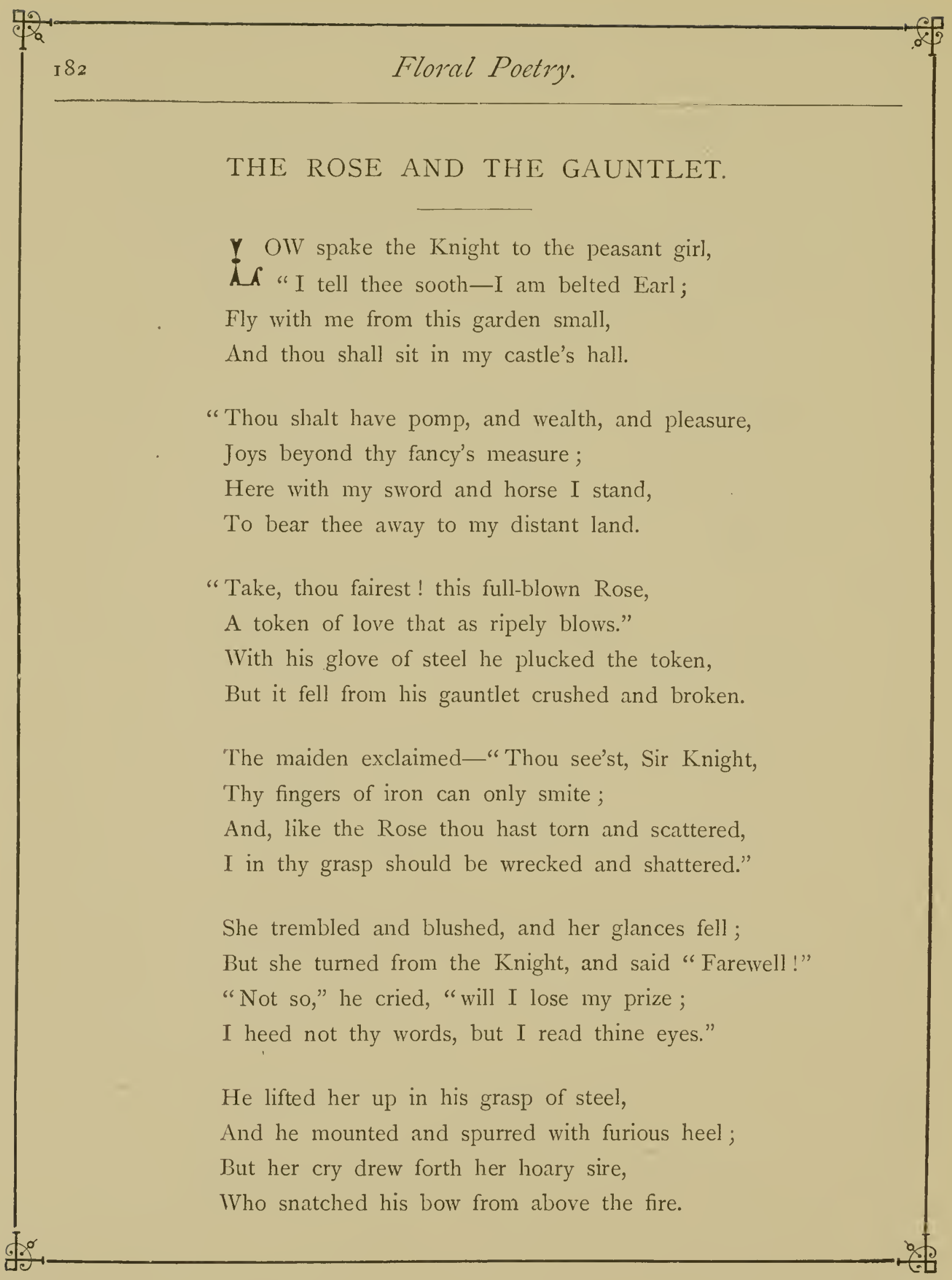




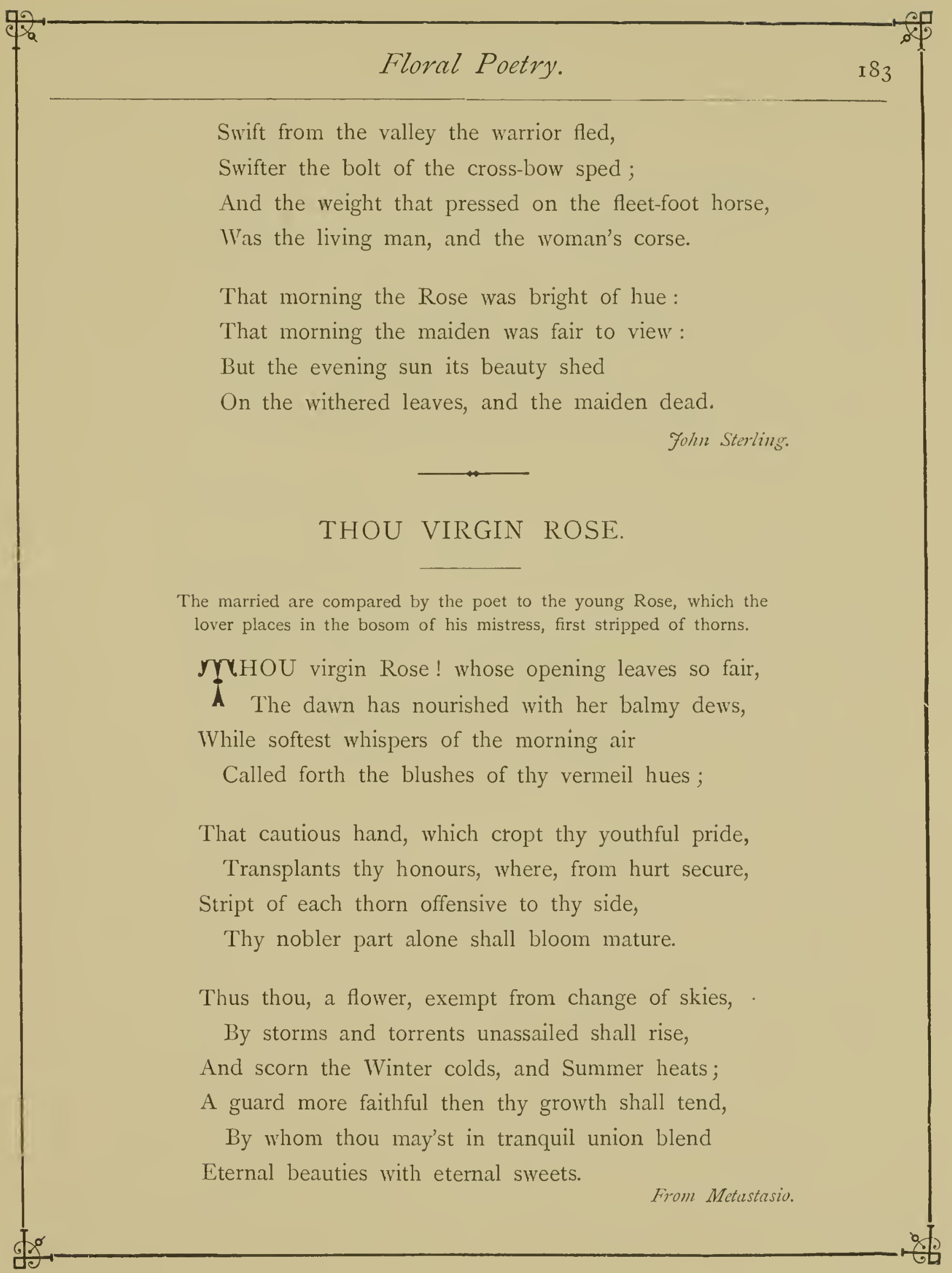




\section{WORSHIP OF THE ROSE-TREE.}

UTHOR of beauty, spirit of power,

7 Thou who didst will that the Rose should be,

Here is the place, and this the hour

To seek thy presence, and bow to thee.

Bright is the world with the sun's first ray,

Cool is the dew on the soft, green sod;

The Rose-tree blooms, while the birds sing praise,

And earth gives glory to nature's God.

Under this beautiful work of thine,

The flowery boughs that are bending o'er

The glistening turf, to thy will divine

I kneel, and its Maker and mine adore.

Thou art around us; the robe of light

Touches the gracefully waving tree;

Turning to jewels the tears of night,

And making the buds unfold to thee.

Thy name is marked in delicate lines,

On flower and leaf that deck the stem;

Thy care is seen, and thy wisdom shines,

In even the thorn that is guarding them.

Now while the Rose that has burst her cup,

Opens her heart, and freely throws

To me her odours, I offer up

Thanks to the Being who made the Rose.

IT. F. Gould. 


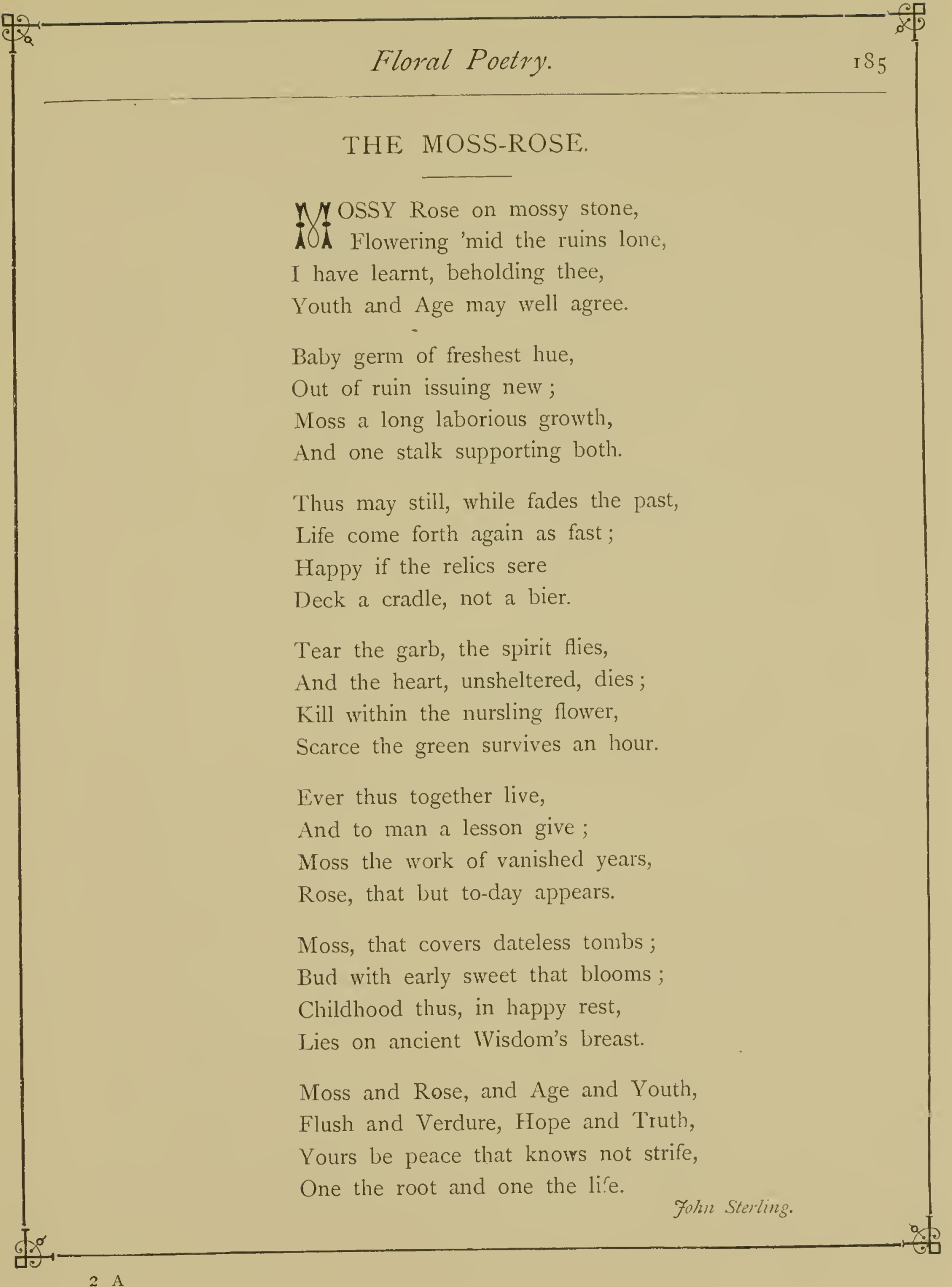




\section{THE MOSS-ROSE.}

yrute Rose arose in Sharon's vale,

$\dot{A}$ And bloomed in Eden beauteously;

It drank the breath of southern gale;

It proved the warmth of Summer sky ;

But o'er thy growth no Summer rose,

But drifted lay the untrodden snows.

The Rose of England, Rose of yore,

In lily and in crimson hue,

Its bloom was dipped in human gore,

And sullied were its leaves to view ;

But thou hast spread amidst the storm, In stainless purity, thy form.

Sweet innocence! by mercy fed,

With light and warmth, and shelter meet,

Whilst Winter all his horrors sped

In drifted snow and driving sleet.

Thus have I seen in maiden form

A beauteous nursling of the storm.

Sweet purity! no grosser breath

Of fervid winds and scorching skies,

Taught thee to spring from mother earth,

And 'midst impurities arise :

But thou hast sprung, a lovely thing,

Nor proved the genial breath of Spring. 


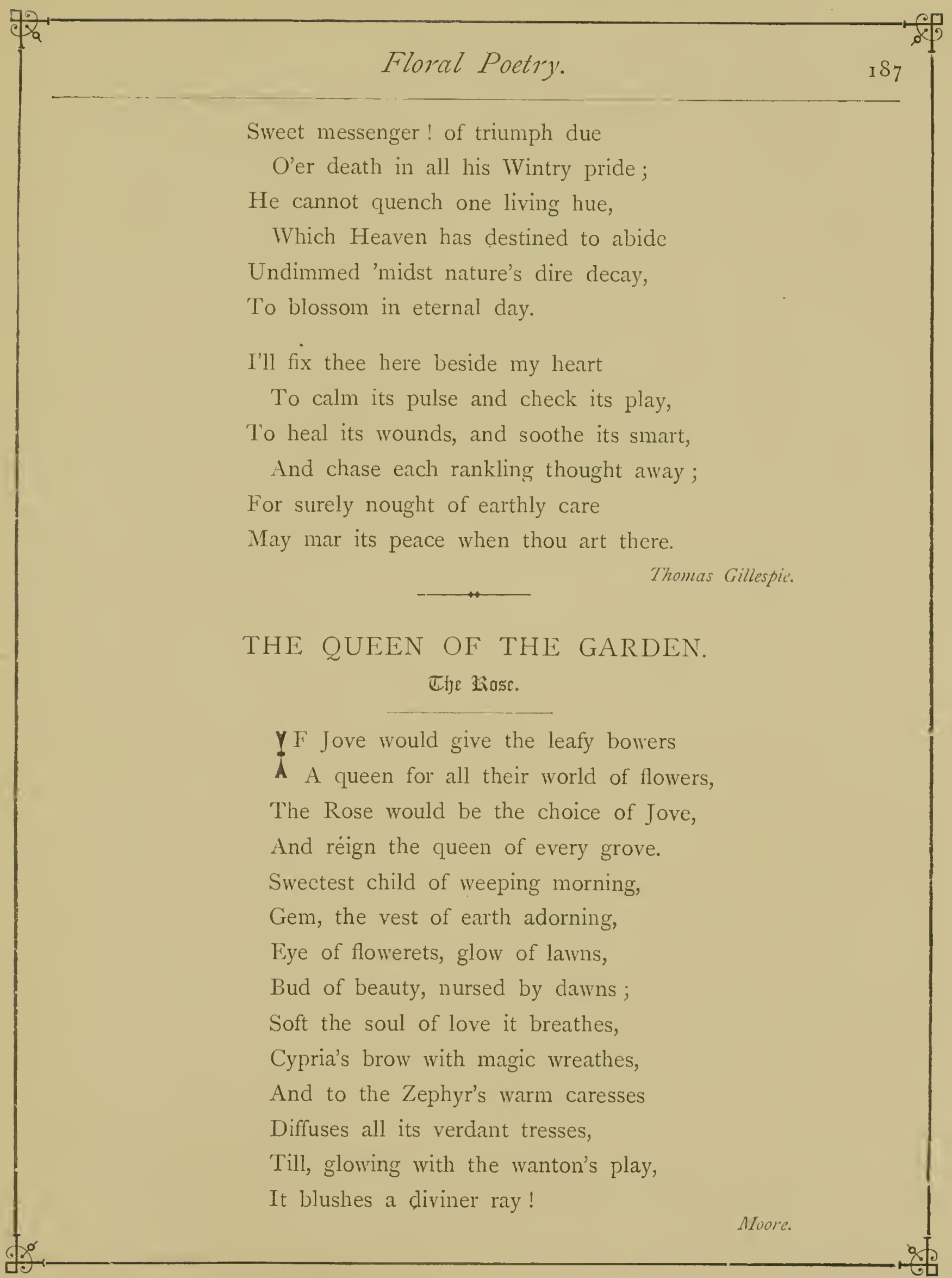




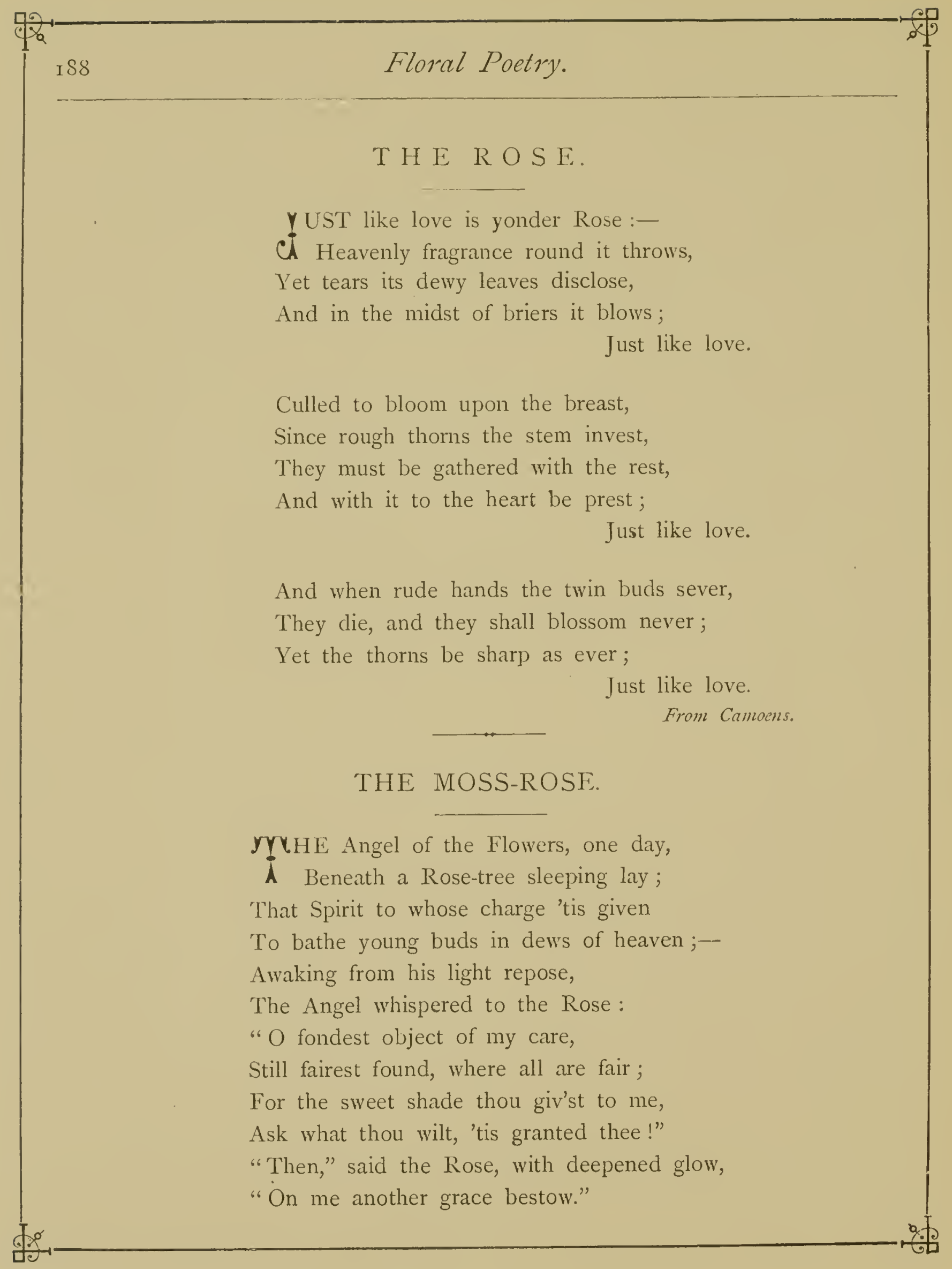




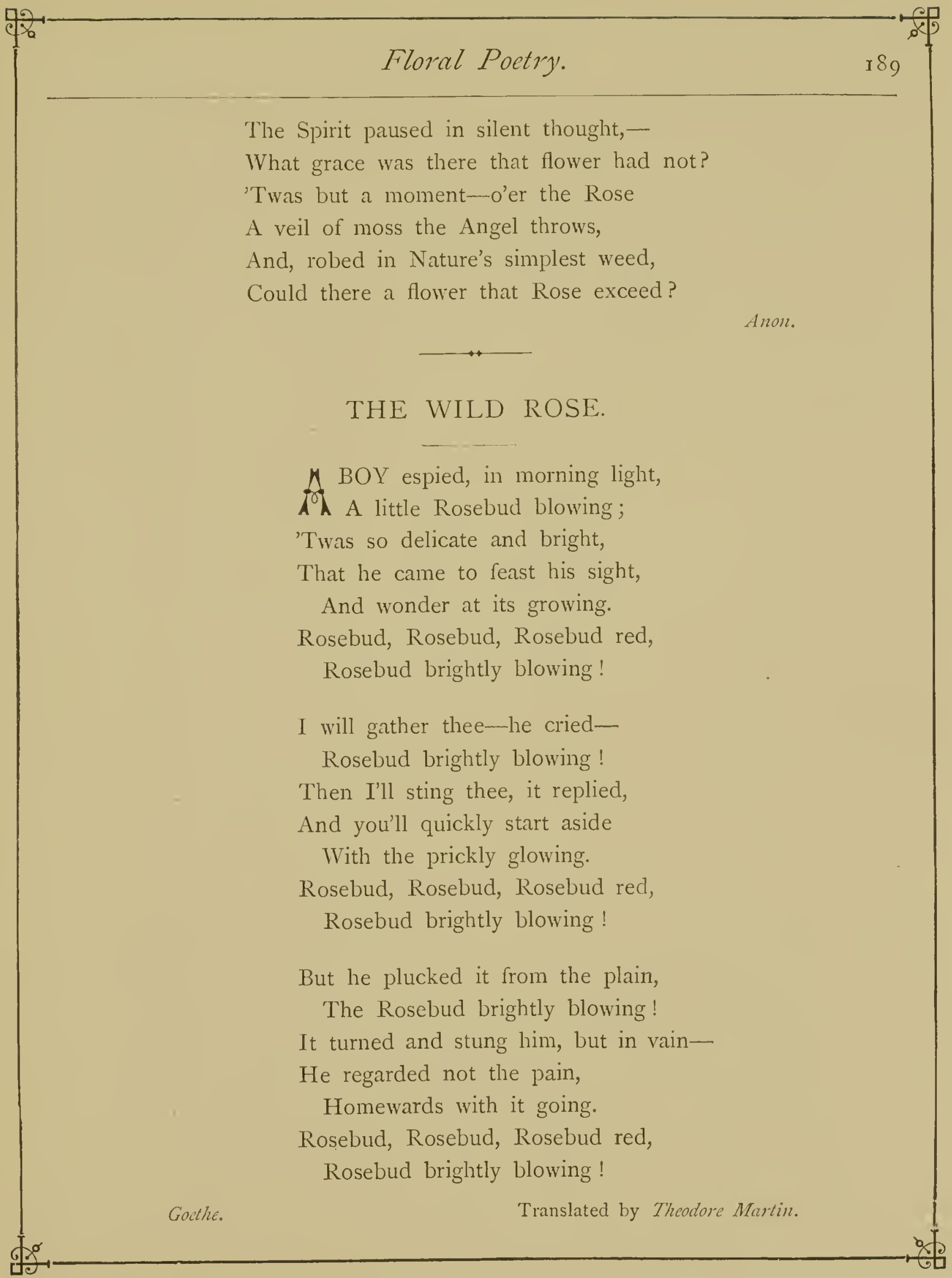




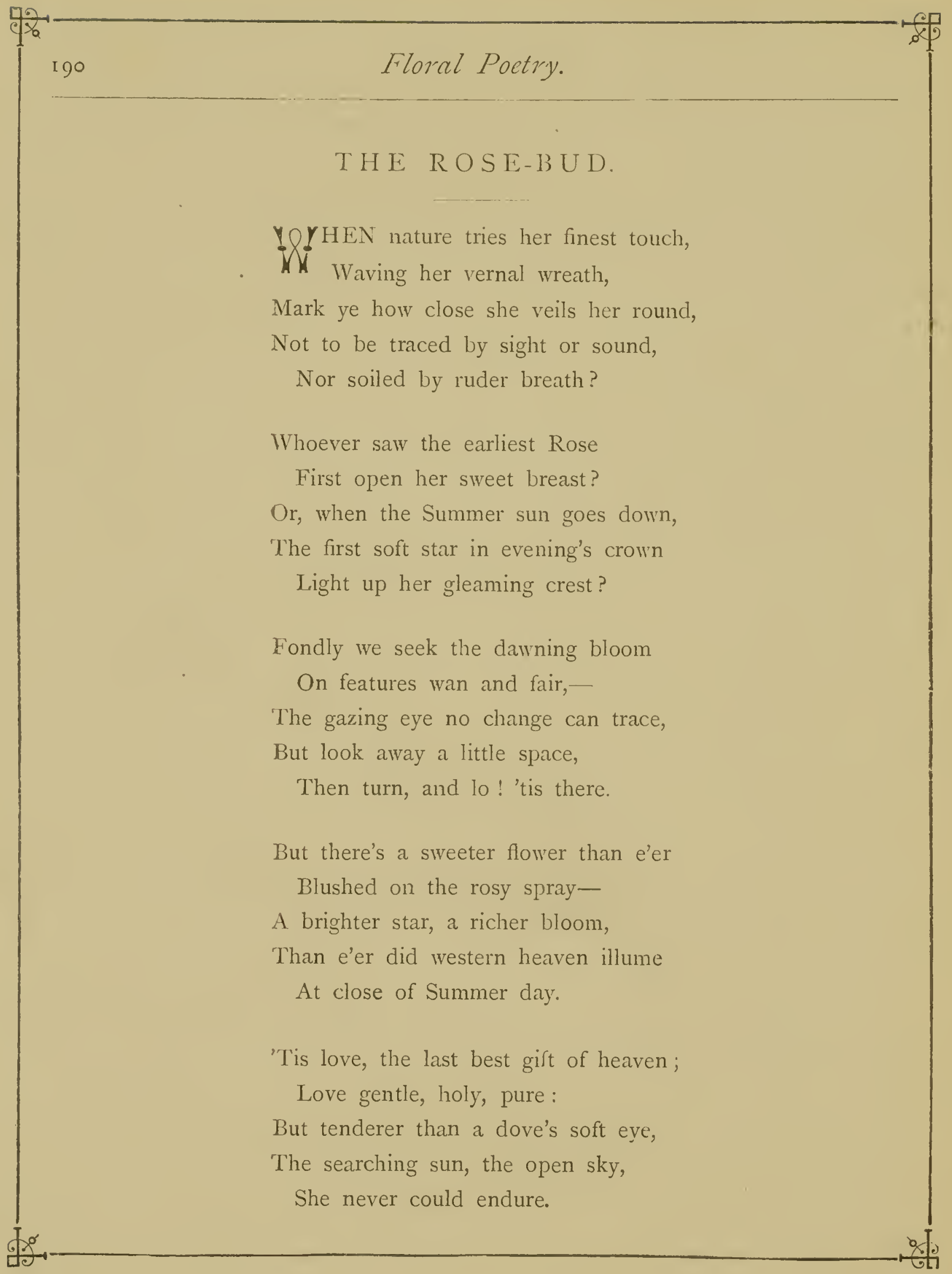




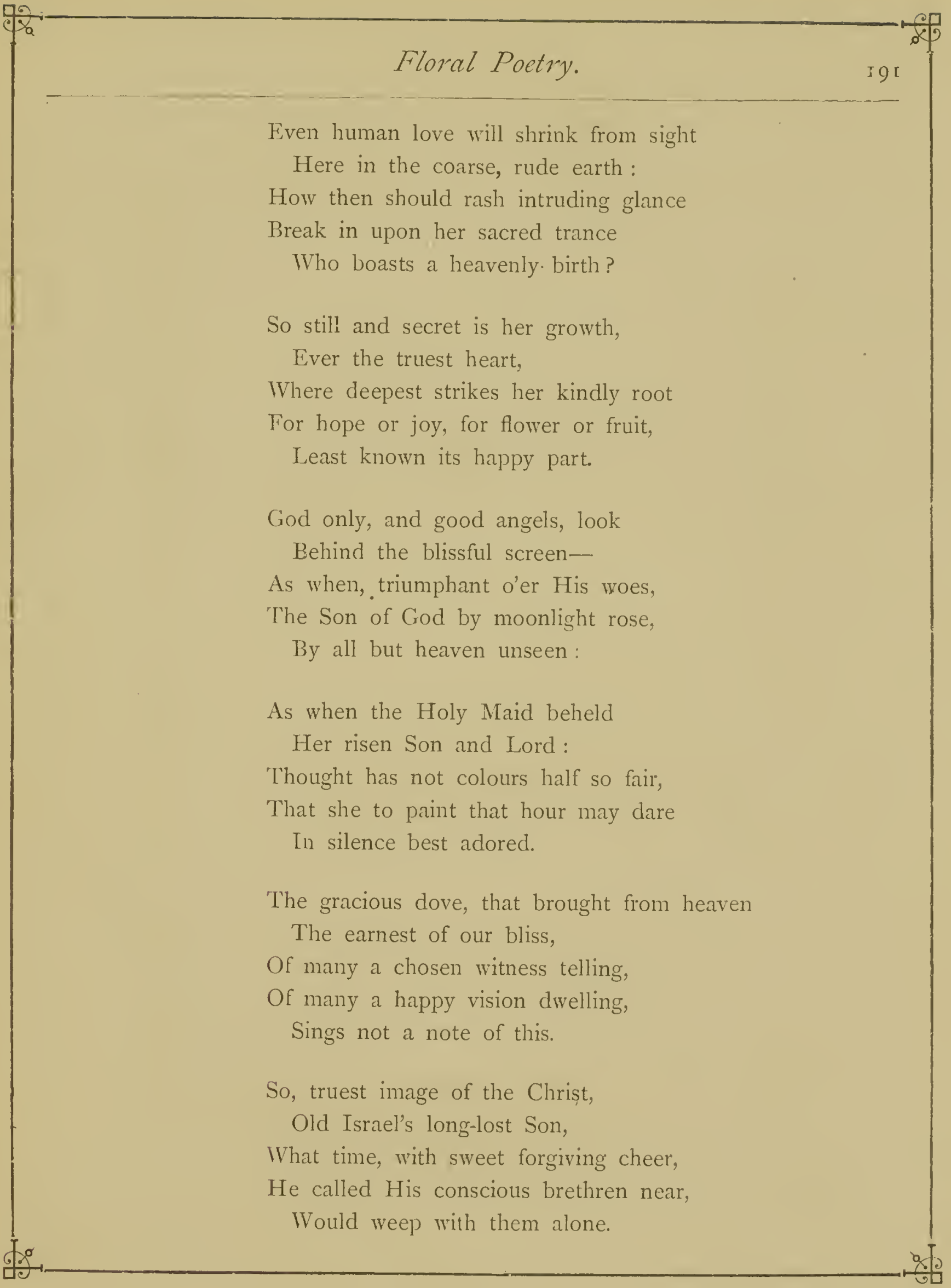




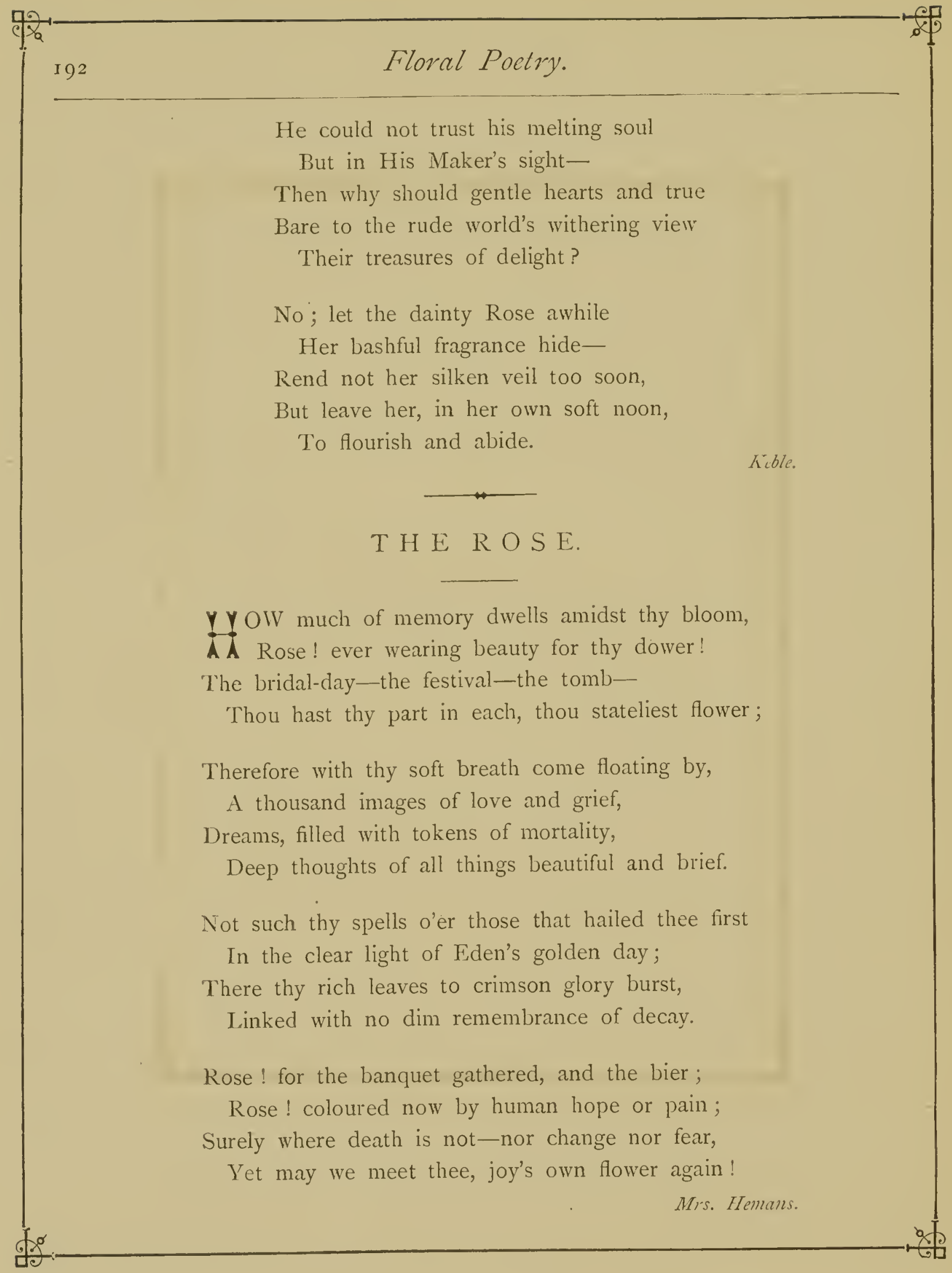




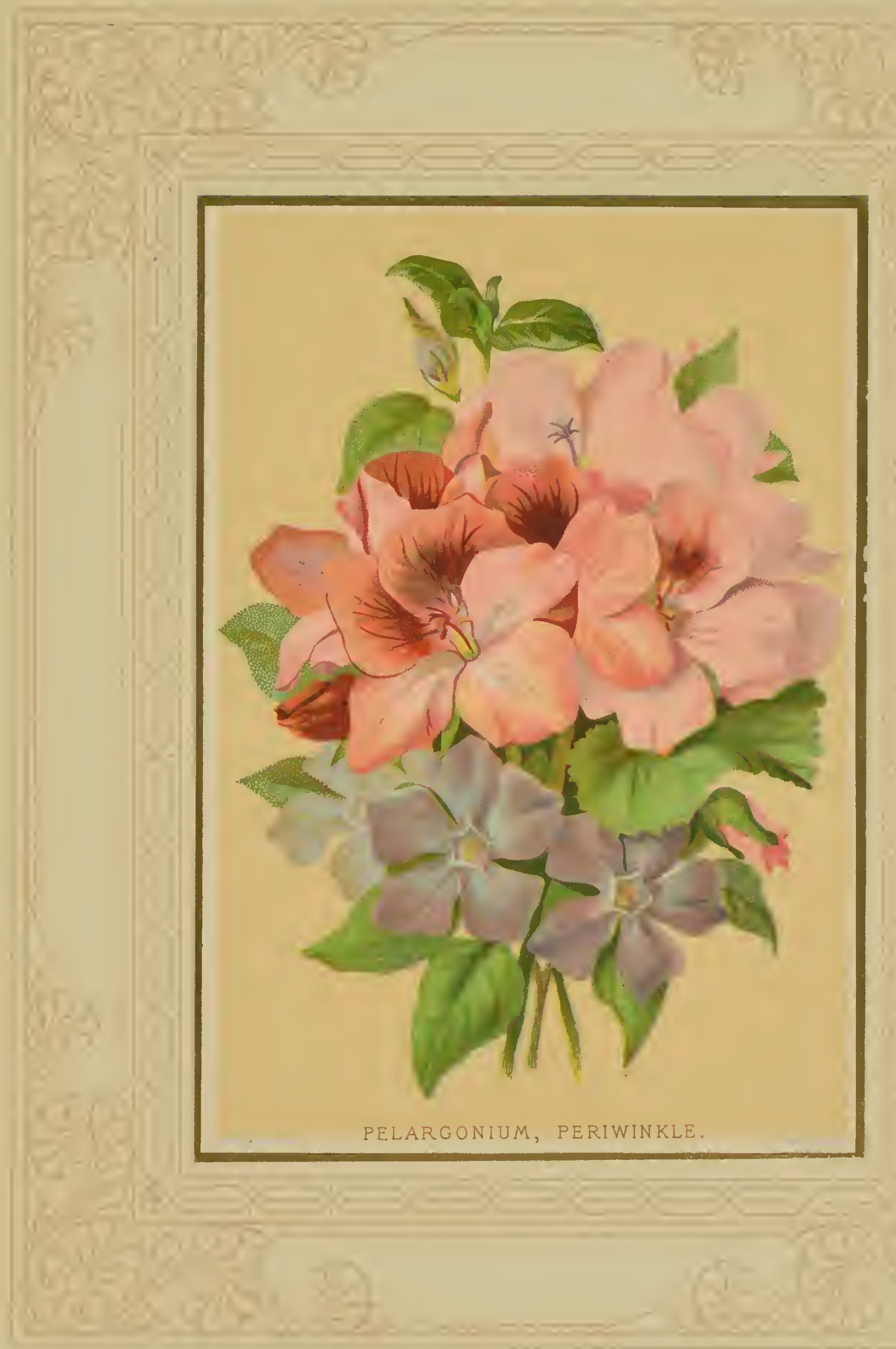




\section{A CHRISTMAS ROSE.}

If HEN the days are dark and cloudy

X And the year's wreck strews the earth,

Pure, all around besoiled,

Springs the Christmas Rose to birth.

So when earth's wide realms were dark

With sin, and hate, and strife,

Sinless, the Son of God

Came to His earthly life.

Then a Christmas Rose I send thee,

Now Wintry skies are drear,

The pledge of Christ's abiding

Through all the long New Year.

Rev. Canon Gover.

\section{CUPID AND THE DIAL.}

NE day, young frolic Cupid tried

To scatter Roses o'er the hours,

And on the dial's face to hide

The course of time with many flowers.

By chance, his rosy wreaths had wound

Upon the hands, and forced them on;

And, when he looked again, he found

The hours had passed, the time was done.

"Alas!" said Love, and dropped his flowers,

"I've lost my time in idle play;

The sweeter I would make the hours,

The quicker they are passed away."

Arron. 


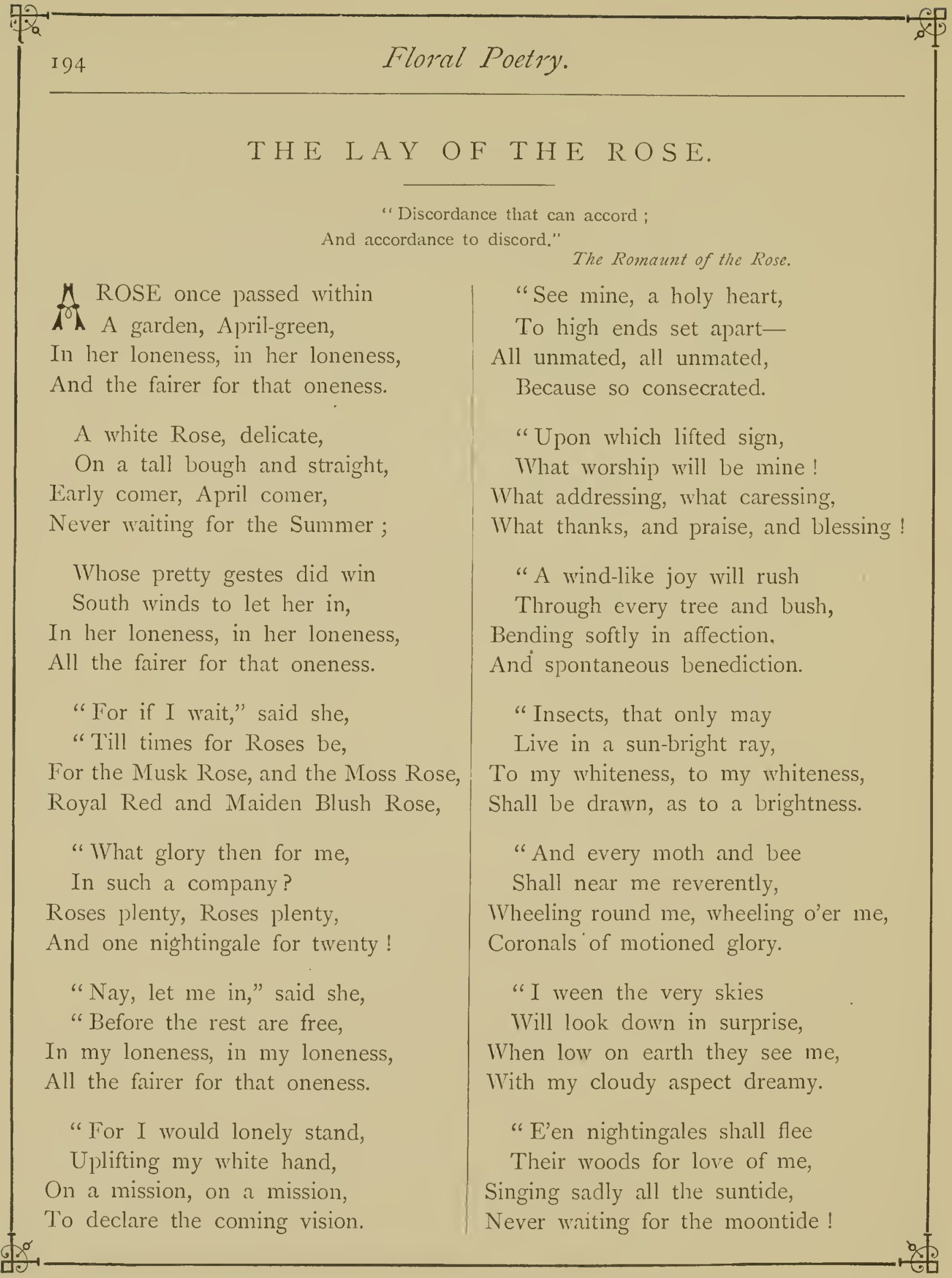


"Three larks shall leave a cloud To my whiter beauty vowed, Singing gladly all the moontide, Never waiting for the suntide."

So praying did she win South winds to let her in, In her loneness, in her loneness, And the fairer for that oneness.

But out, alas! for her, No thing did minister To her praises, to her praises, More than might unto a Daisy's.

No tree nor bush was seen

To boast a perfect green, Scarcely having, scarcely having One leaf broad enow for waving.

The little flies did crawl Along the southern wall, Faintly shifting, faintly shifting, Wings scarce strong enow for lifting.

The nightingale did please

To loiter beyond seas, Guess him in the happy islands, Hearing music from the silence.

The lark too high or low, Did haply miss her soWith his crest down in the gorses, And his song in the star-courses!

Only the bee, forsooth, Came in the place of bothDoing honour, doing honour, To the honey-dews upon her.
The skies looked coldly down, As on a royal crown; Then, drop by drop, at leisure, Began to rain for pleasure.

Whereat the earth did seem

To waken from a dreamWinter frozen, Winter frozen, Her anguish eyes unclosing,

Said to the Rose, "Ha, Snow!

And art thou fallen so?

Thou who wert enthronéd stately Along my mountains lately.

"Hullo, thou world-wide snow!

And art thou wasted so?

With a little bough to catch thee, And a little bee to watch thee?"

Poor Rose, to be misknown!

Would she had ne'er been blown, In her loneness, in her loneness, All the sadder for that oneness.

Some words she tried to say, Some sigh—ah, well away! But the passion did o'ercome her, And the fair frail leaves dropped from her.

Dropped from her, fair and mute,

Close to a poet's foot, Who beheld them, smiling lowly, As at something sad yet holy:

Said, "Verily and thus,

So chanceth e'er with us, Poets, ringing sweetest snatches, While deaf men did keep the watches. 
"Saunting to come before

Our own age evermore, In a loneness, in a loneness, And the nobler for that oneness.

"But if alone we be,

Where is our empiry?

And if none can reach our stature, Who will mate our lofty nature?

"What bell will yield a tone

Save in the air alone?

If no brazen clapper bringing, Who can bear the chiméd ringing?

"What angel but would seem

To sensual eyes glent-dim? And without assimilation, Vain is interpenetration!

"Alas! what can we do,

The Rose and poet too, Who both antedate our mission In an unpreparéd season?

"Drop, leaf-be silent, songCold things we came among!

We must warm them, we must warm them, Ere we even hope to charm them.

"Howbeit"-here his face Heightened around the place, So to mark the outward turning Of his spirit's inward burning-

"Something it is to hold

In God's world's manifold, First revealed to creatures' duty, A new form of His mild beauty.
"Whether that form respect

The sense or intellect, Holy rest in soul or pleasance, The chief beauty's sign of presence.

"Holy in me and thee,

Rose fallen from the tree, Though the world stand dumb around us, All unable to expound us.

"Though none us deign to bless, Blessed are we natheless;

Blessed age and consecrated In that, Rose, we were created!

"Oh, shame to poet's lays,

Sung for the dole of praiseHoarsely sung upon the highway, With an 'obolum da mini"!

"Shame! shame to poet's soul, Pining for such a dole, When heaven-called to inherit The high throne of his own spirit!

"Sit still upon your thrones,

O ye poetic ones!

And if, sooth, the world decry you, Why, let that world pass by you!

"Ye to yourselves suffice,

Without its flatteries; Self-contentedly approve you Unto Him who sits above you.

"In prayers that upward mount, Like to a sunnéd fount, And, in gushing back upon you, Bring the music they have won you! 
Through fissures of the clay-

Promised things, which shall be given And sung ever up in heaven!

"For life, so lonely vain,

For death, which breaks the chain-

For this sense of present sweetness, And this yearning to completeness!"

Elizabeth B. Browuning.

\section{THE HALF-BLOWN ROSE.}

YOK, now, now we esteem the half-blown Rose,

If The image of thy blush and Summer's honour;

Whilst yet her tender bud doth undisclose

That full of beauty time bestows upon her.

No sooner spreads her glories to the air,

But straight her wide-blown pomp comes to decline;

She then is scorned that late adorned the fair;

So fade the roses of those cheeks of thine;

No April can revive thy withered flowers,

Whose springing grace adorns thy glory now;

Swift, speedy time, feathered with flying hours,

Dissolves the beauty of the fairest brow:

Then do not thou such treasure waste in vain,

But love now whilst thou may'st be loved again.

Daniel. 


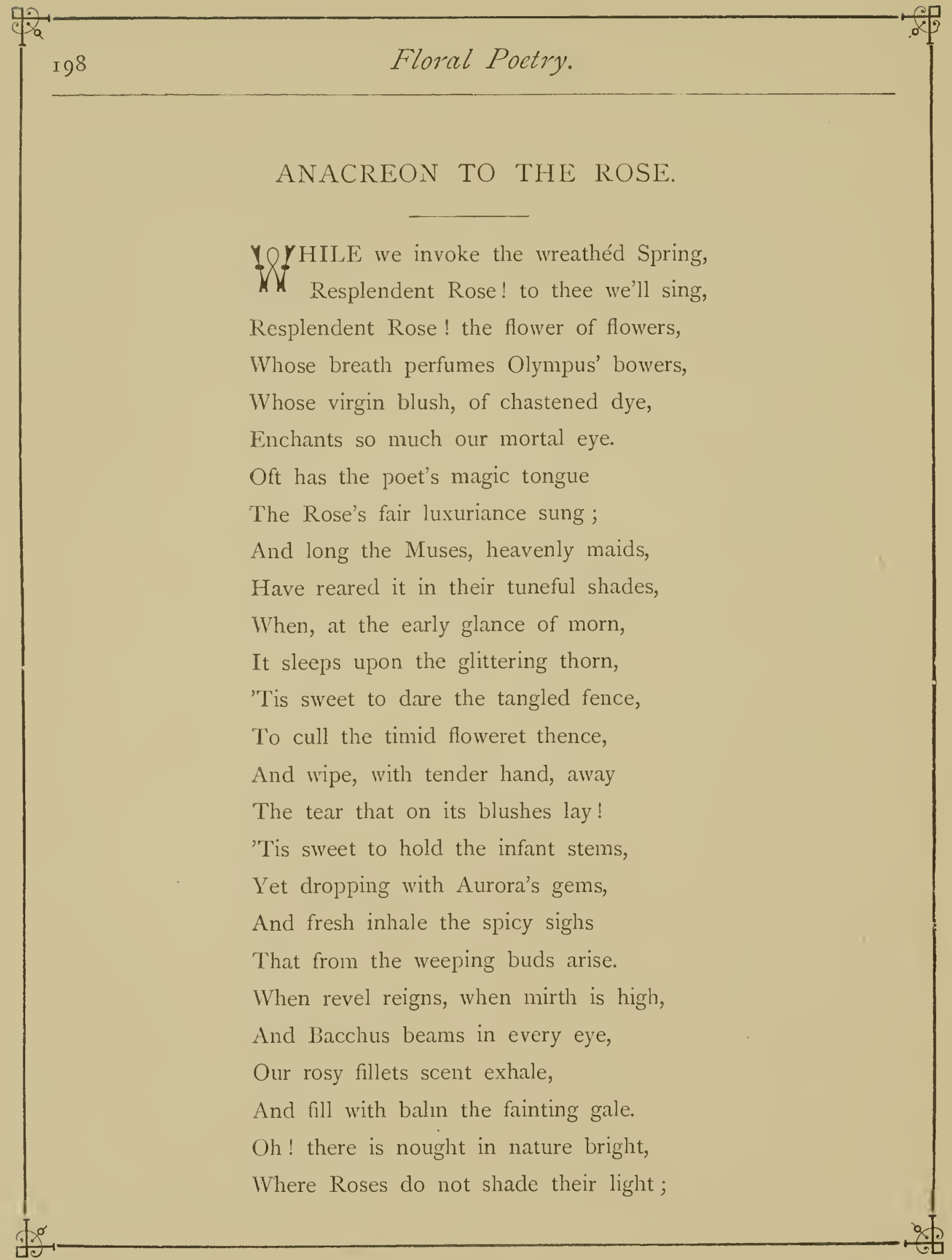




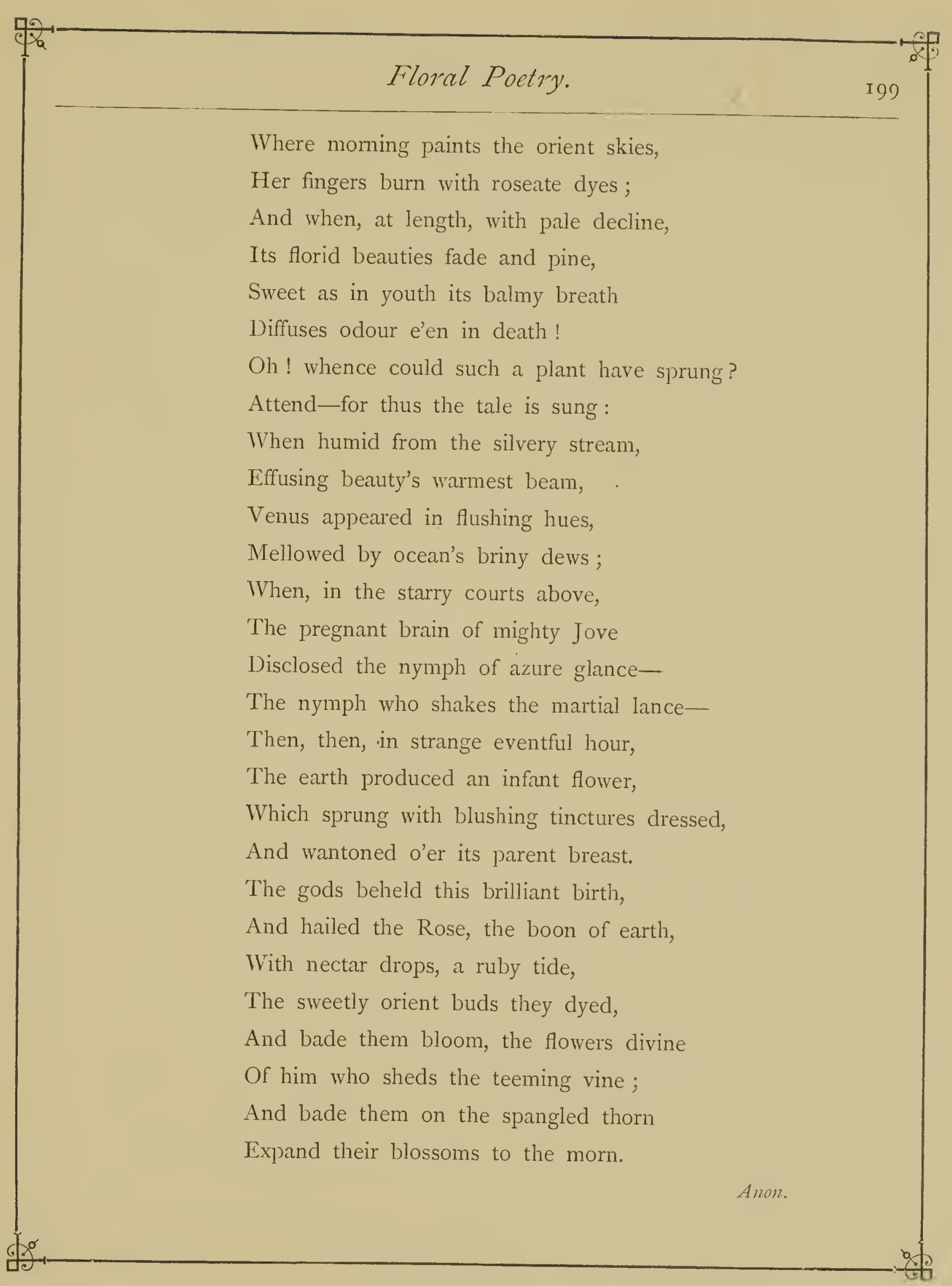




\section{A MOUR OF THE ROSE.}

Drigin of the Thorns.

YOUNG Love, rambling through the wood,

A Found me in my solitude,

Bright with dew and freshly blown

And trembling to the Zephyr's sighs;

But as he stopped to gaze upon

The living gem with raptured eyes,

It chanced a bee was busy there,

Searching for its fragrant fair ;

And Cupid, stooping too, to sip,

The angry insect stung his lip;

And, gushing from the ambrosial cell,

One bright drop on my bosom fell.

Weeping, to his mother he

Told the tale of treachery,

And she, her vengelul boy to please,

Strung his bow with captive bees,

But placed upon my slender stem

The poisoned sting she plucked from them;

And none since that eventful morn

Have found the flower without a thorn.

Anon. 


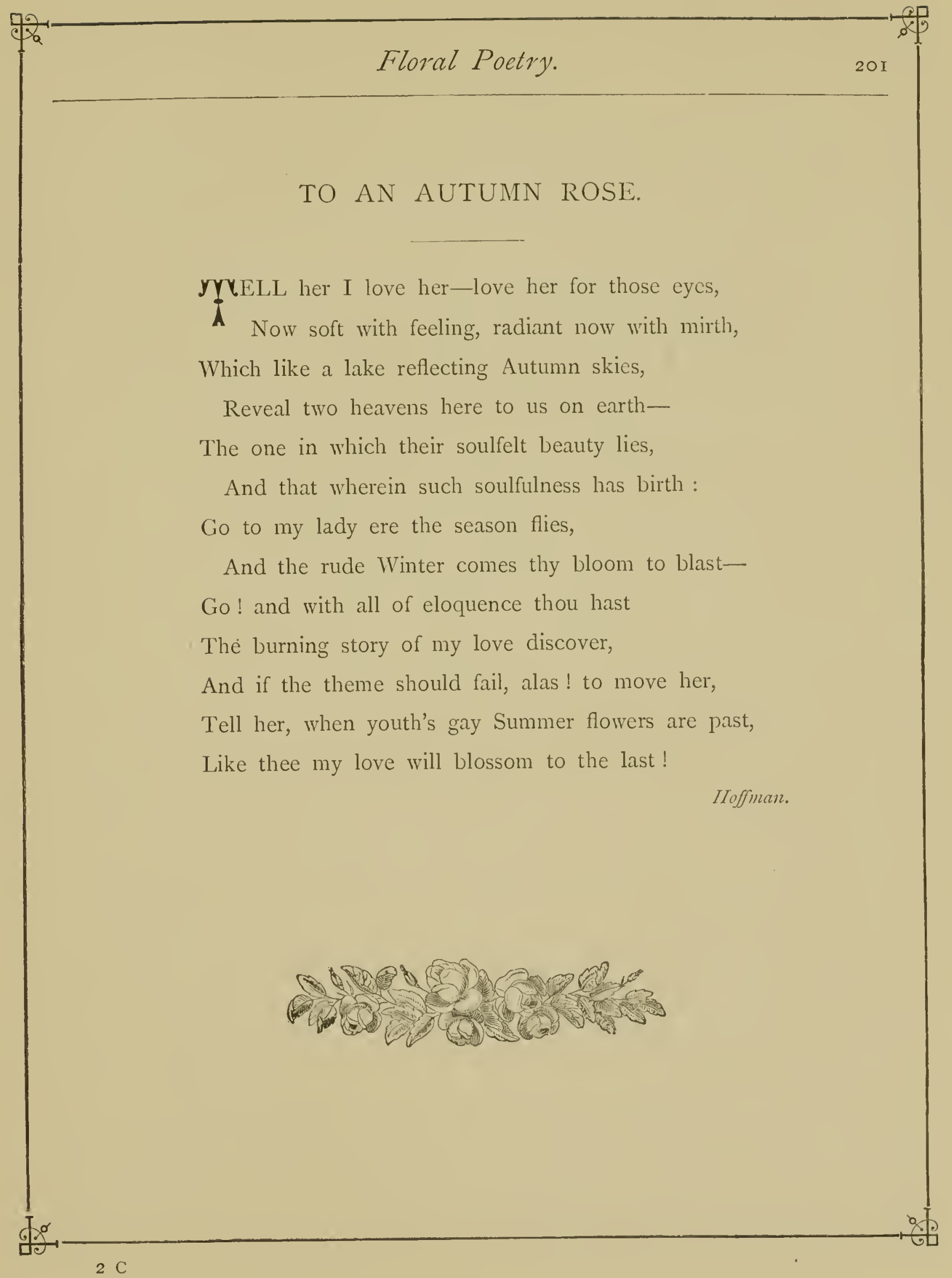




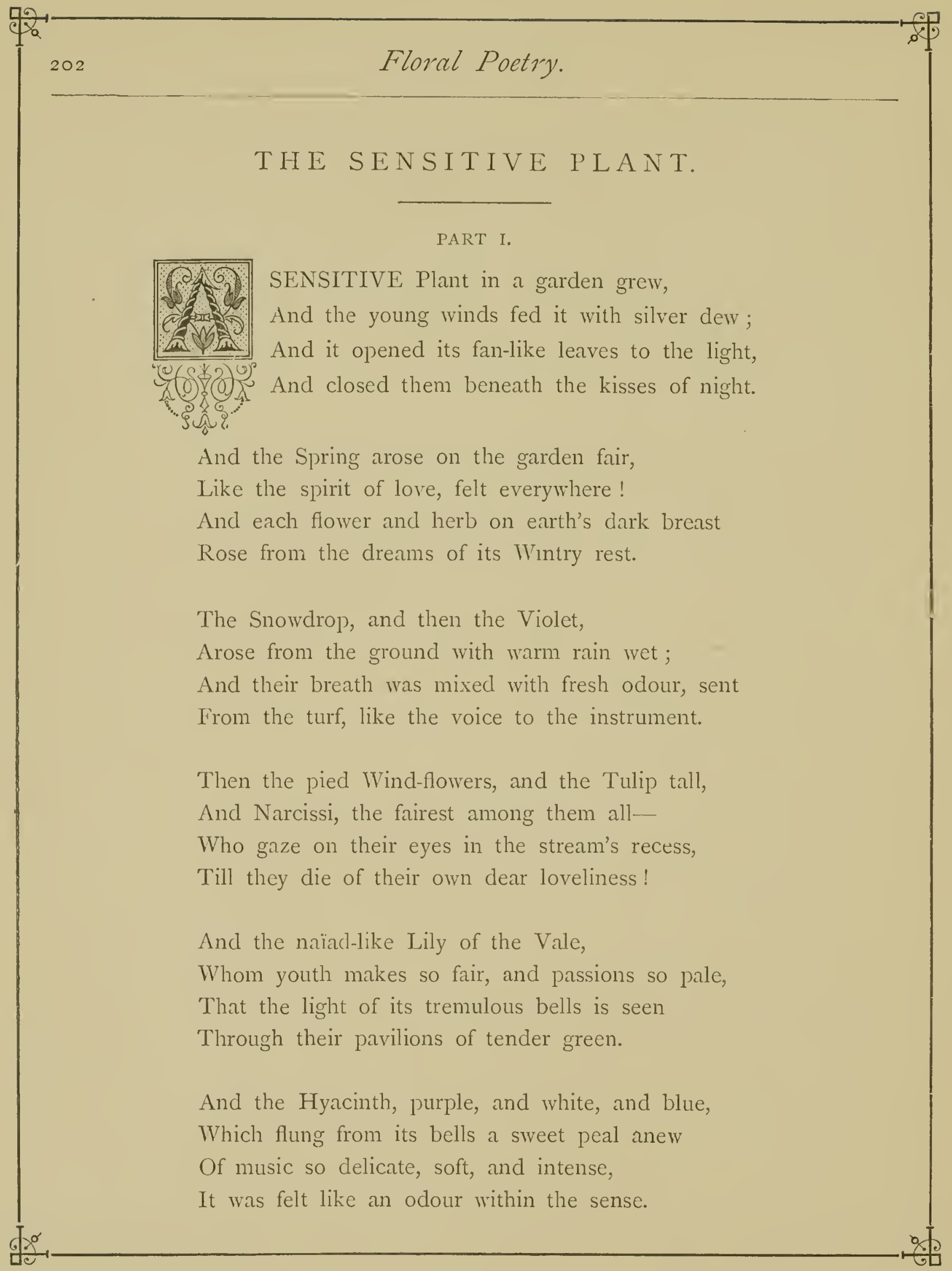




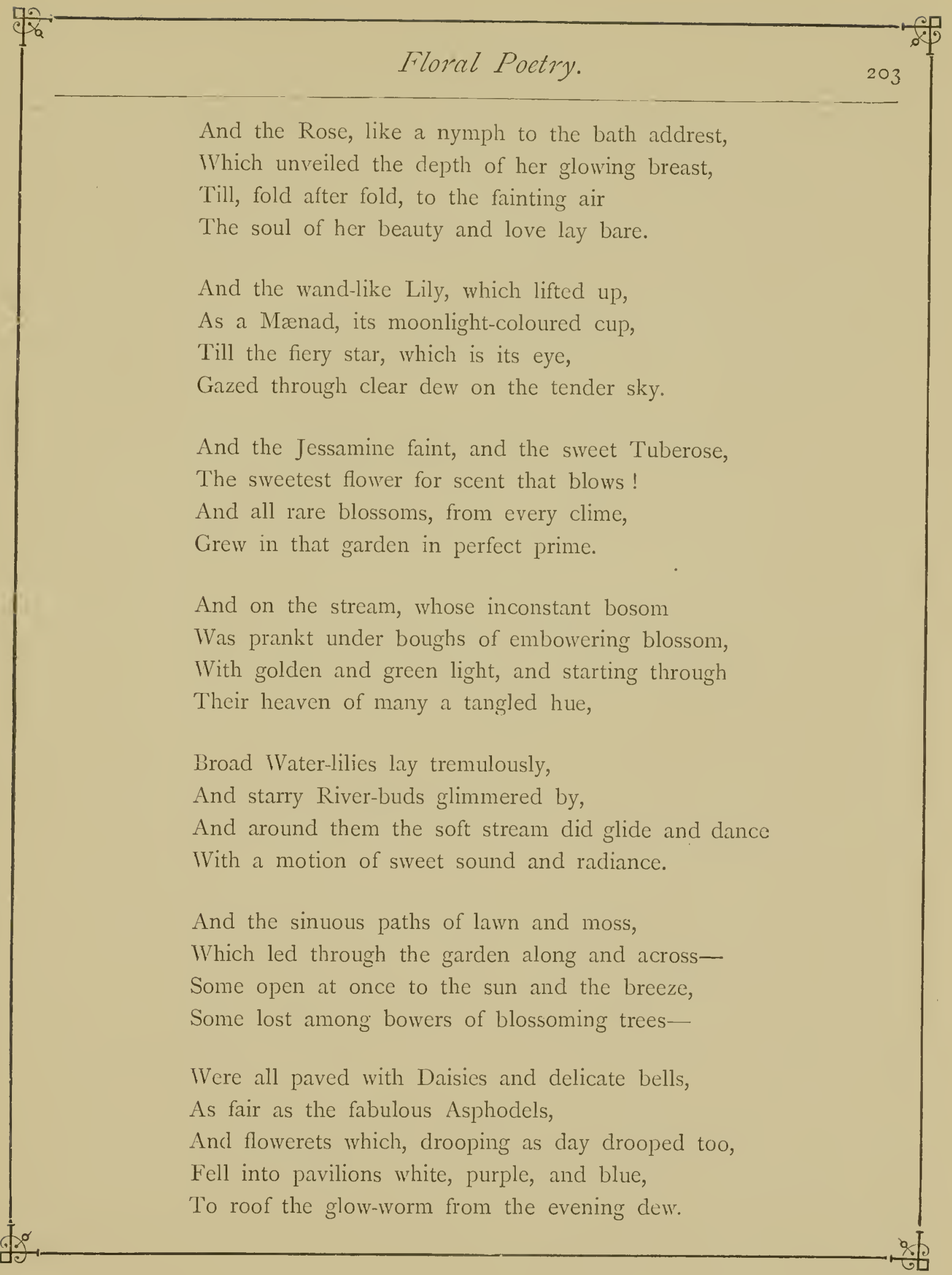




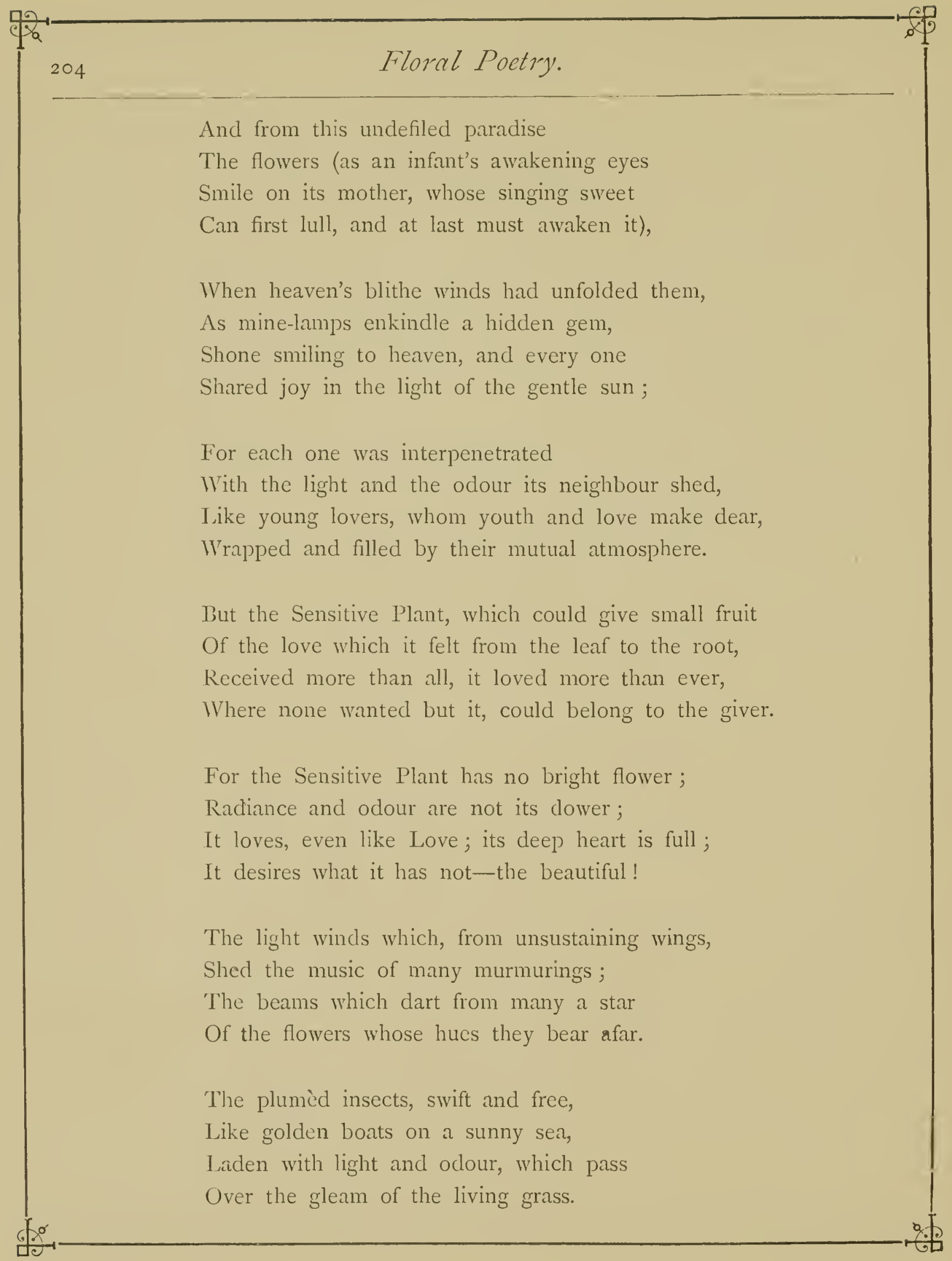


The unseen clouds of the dew, which lie

Like fire in the flowers till the sun rides high,

'Then wander like spirits among the spheres,

Each cloud faint with the fragrance it bears.

The quivering vapours of dim noon-tide,

Which, like a sea, o'er the warm earth glide,

In which every sound, and odour, and beam,

Move as reeds in a single stream.

Each and all like ministering angels were,

For the Sensitive Plant sweet joy to bear;

Whilst the lagging hours of the day went by,

Iike windless clouds o'er a tender sky.

And when evening descended from heaven above, And the earth was all rest, and the air was all love, And delight, though less bright, was far more deep, And the day's veil fell from the world of sleep;

And the beasts and the birds and the insects were drowned In an ocean of dreanus without a sound;

Whose waves never mark, though they ever impress,

The light sand which paves it-consciousness;

Only overhead the sweet nightingale

Ever sang more sweet as the day might fail,

And snatches of its Elysian chant

Were mixed with the dreams of the Sensitive Plant.

The Sensitive Plant was the earliest Upgathered into the bosom of rest;

A sweet child, weary of its delight, The feeblest, and yet the favourite, Cradled within the embrace of night. 


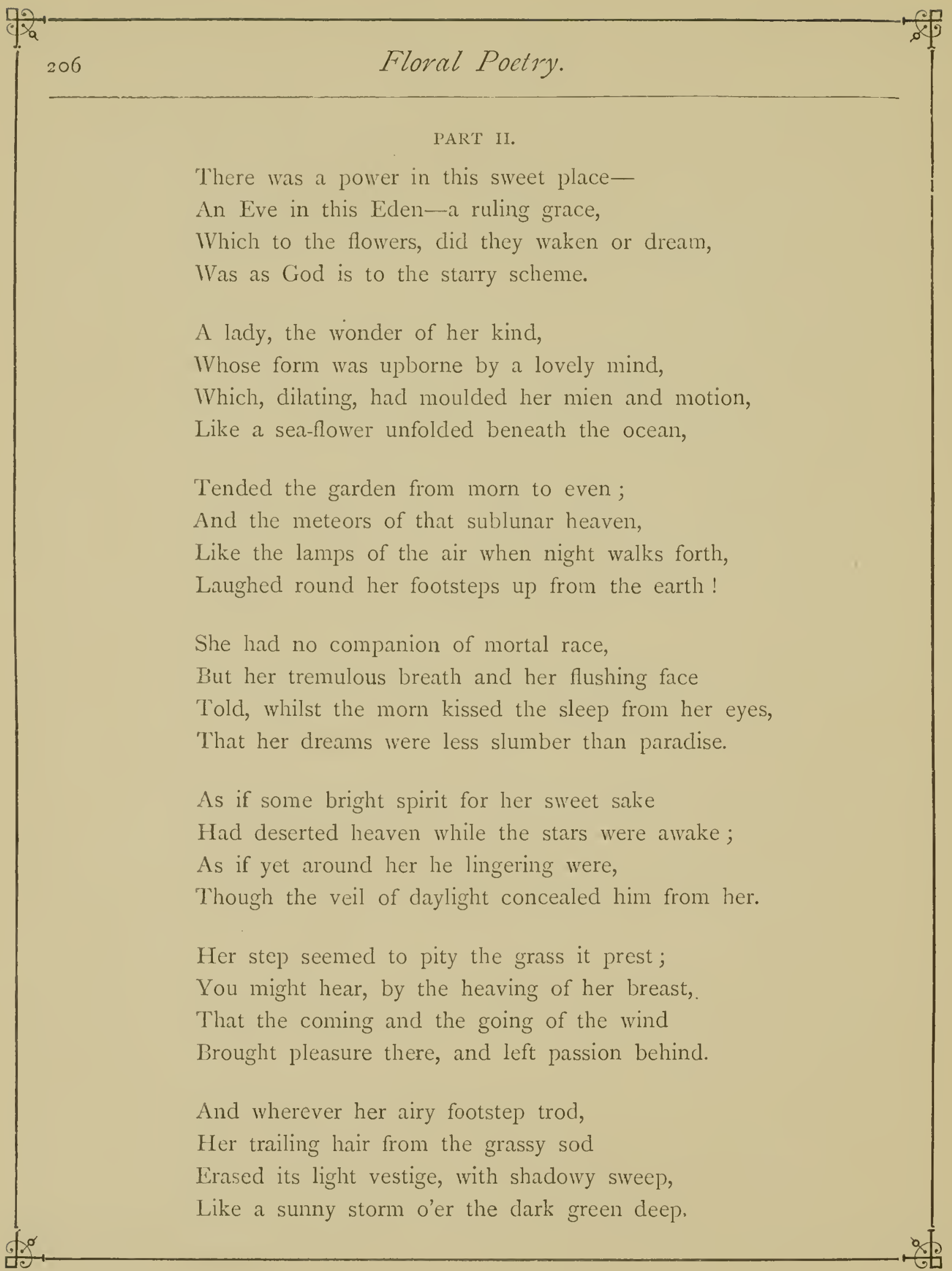




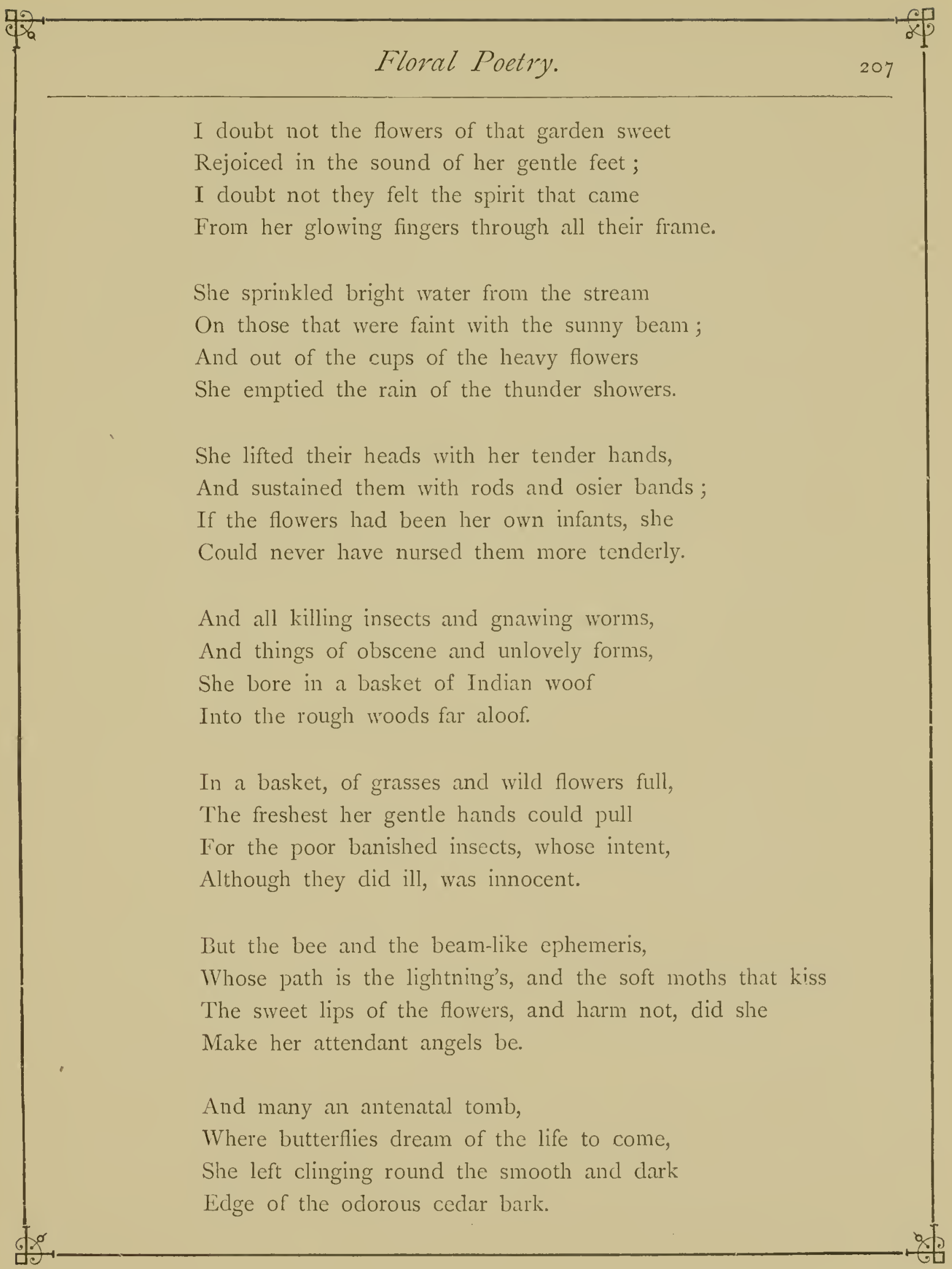


This fairest creature, from earliest spring, Thus moved through the garden, ministering, All the sweet season of the summer-tide, And ere the first leaf looked brown-she died.

\section{PART III.}

Three days the flowers of the garden fair, Iike stars when the noon is awakened, were;

Or the waves of the Baix, ere, luminous, She floats up through the smoke of Vesuvius.

And on the fourth, the Sensitive Plant Felt the sound of the funeral chant, And the steps of the bearers, heavy and slow, And the sobs of the moumers, deep and low,

The weary sound and the heavy breath, And the silent motions of passing death, And the smell, cold, oppressive, and dank, Sent through the pores of the coffin plank.

The dark grass, and the flowers among the grass, Were bright with tears as the crowds did pass, From their sighs the wind caught a mournful tone, And sate in the pines, and gave groan for groan.

The garden, once fair, became cold and foul, Like the corpse of her who had been its soul:

Which at first was lovely, as if in sleep, Then slowly changed, till it grew a heap To make men tremble who never weep.

Swift Summer into the Autumn flowed, And frost in the mist of the morning rode, Though the noon-day sun looked clear and bright, Mocking the spoil of the secret night. 


\section{Floral Poetry.}

The Rose-leaves, like flakes of crimson snow,

Paved the turf and the moss below;

The Lilies were drooping, and white and wan,

Like the head and the skin of a dying man.

And the Indian plants, of scent and hue,

The sweetest that ever were fed on dew,

Leaf after leaf, day by day,

Were massed into the common clay.

And the leaves, brown, yellow, and grey, and red,

And white with the whiteness of what is dead,

Like troops of ghosts on the dry wind passed;

Their whistling noise made the birds aghast.

And the gusty winds waked the wingéd seeds

Out of their birth-place of ugly weeds,

Till they clung round many a sweet flower's stem,

Which rotted into earth with them.

The water-blooms under the rivulet

Fell from the stalks on which they were set;

And the eddies drove them here and there,

As the winds did those of the upper air.

Then the rain came down, and the broken stalks

Were bent and tangled across the walks;

And the leafless network of parasite bowers

Massed into ruin, and all sweet flowers.

Between the time of the wind and the snow,

All loathliest weeds began to grow,

Whose coarse leaves were splashed with many a speck,

Like the water-snake's belly and the toad's back. 


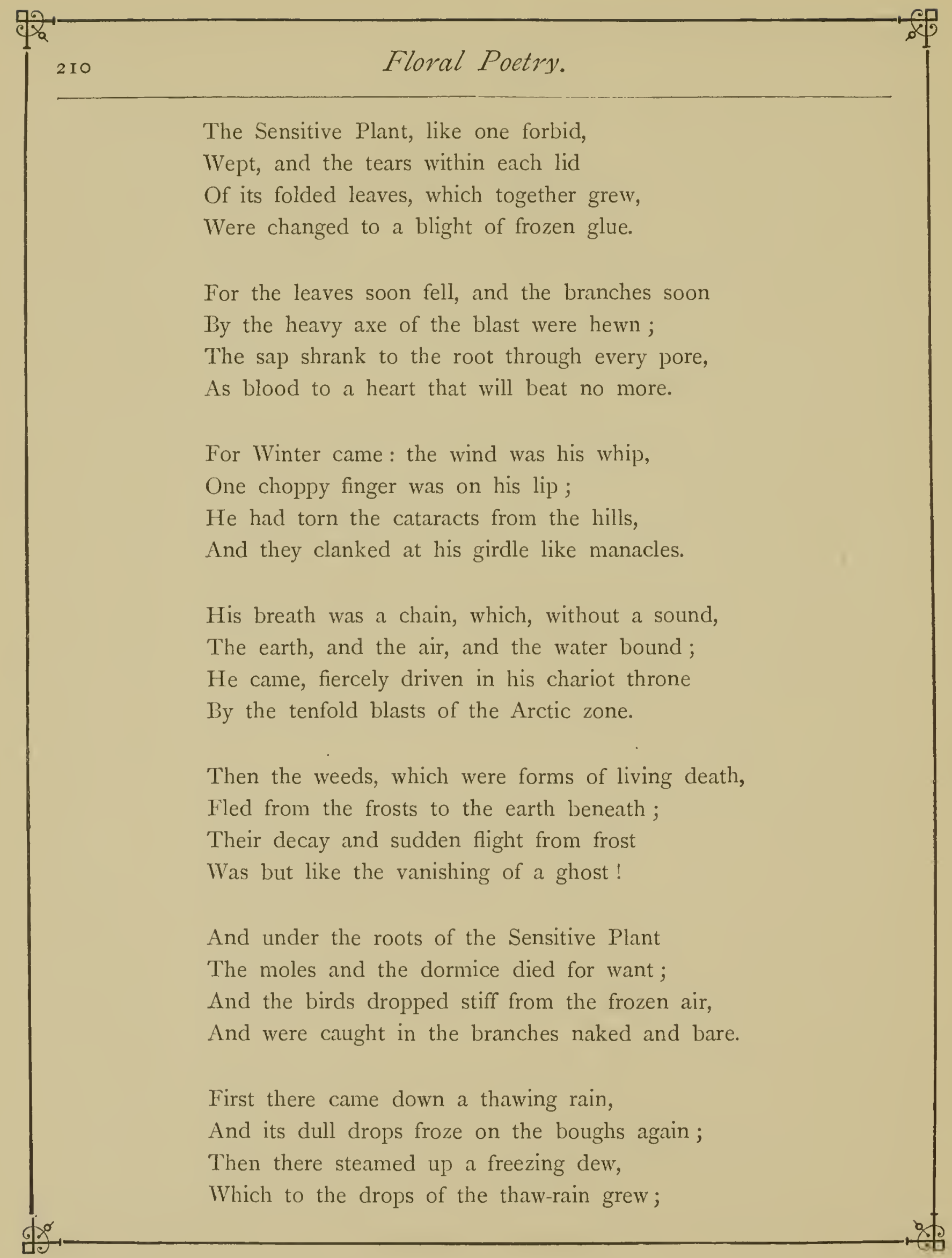




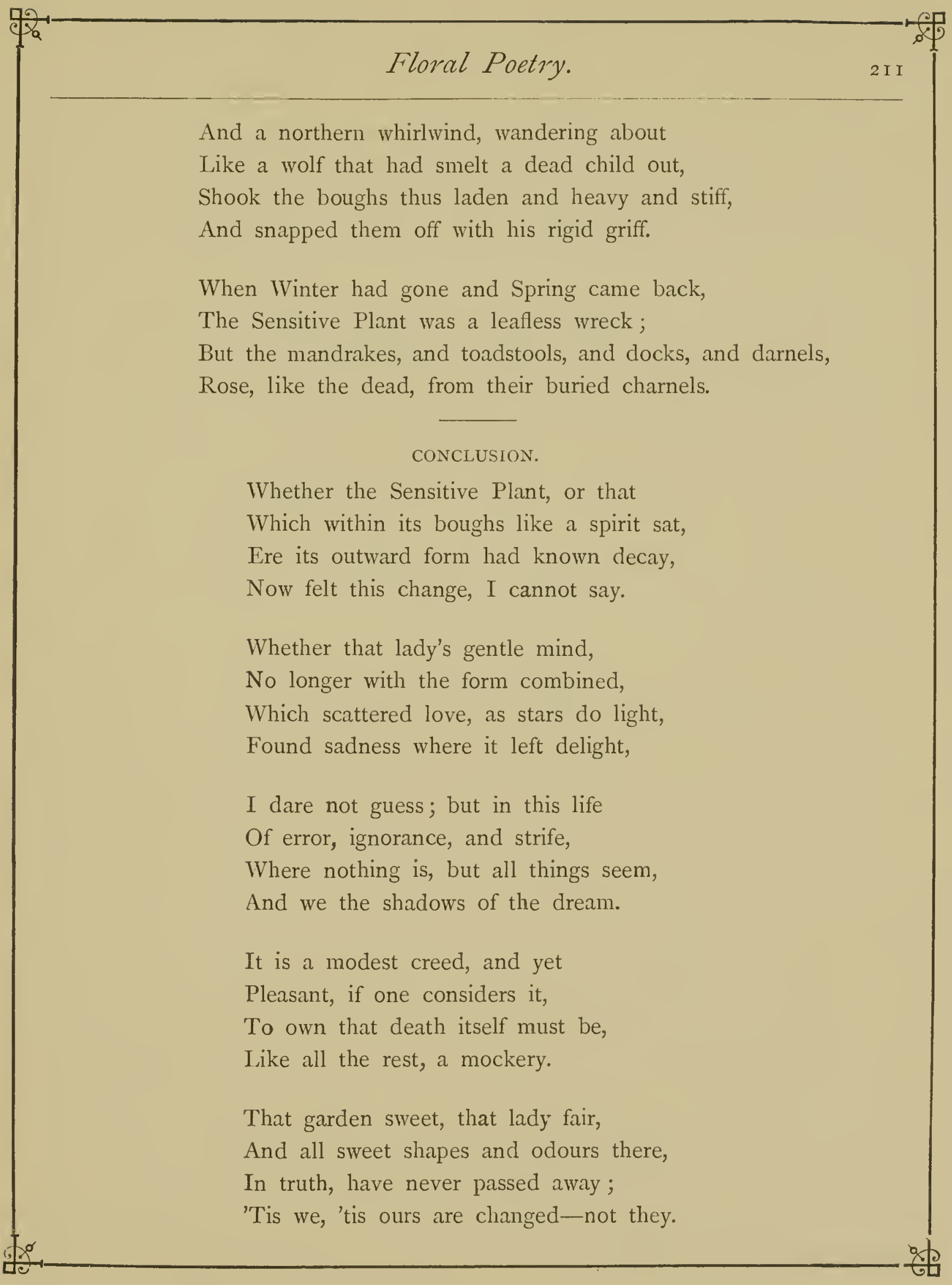




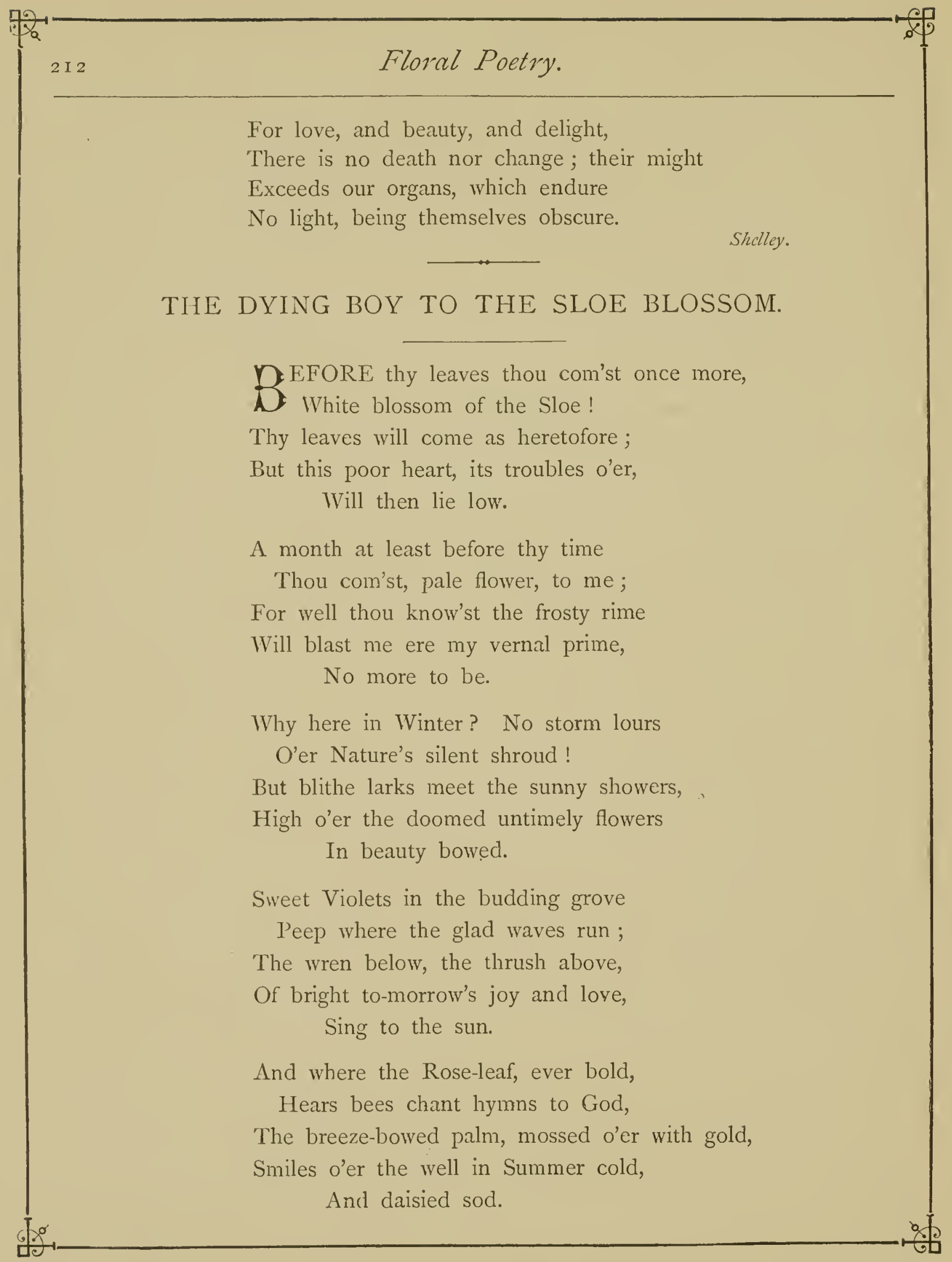




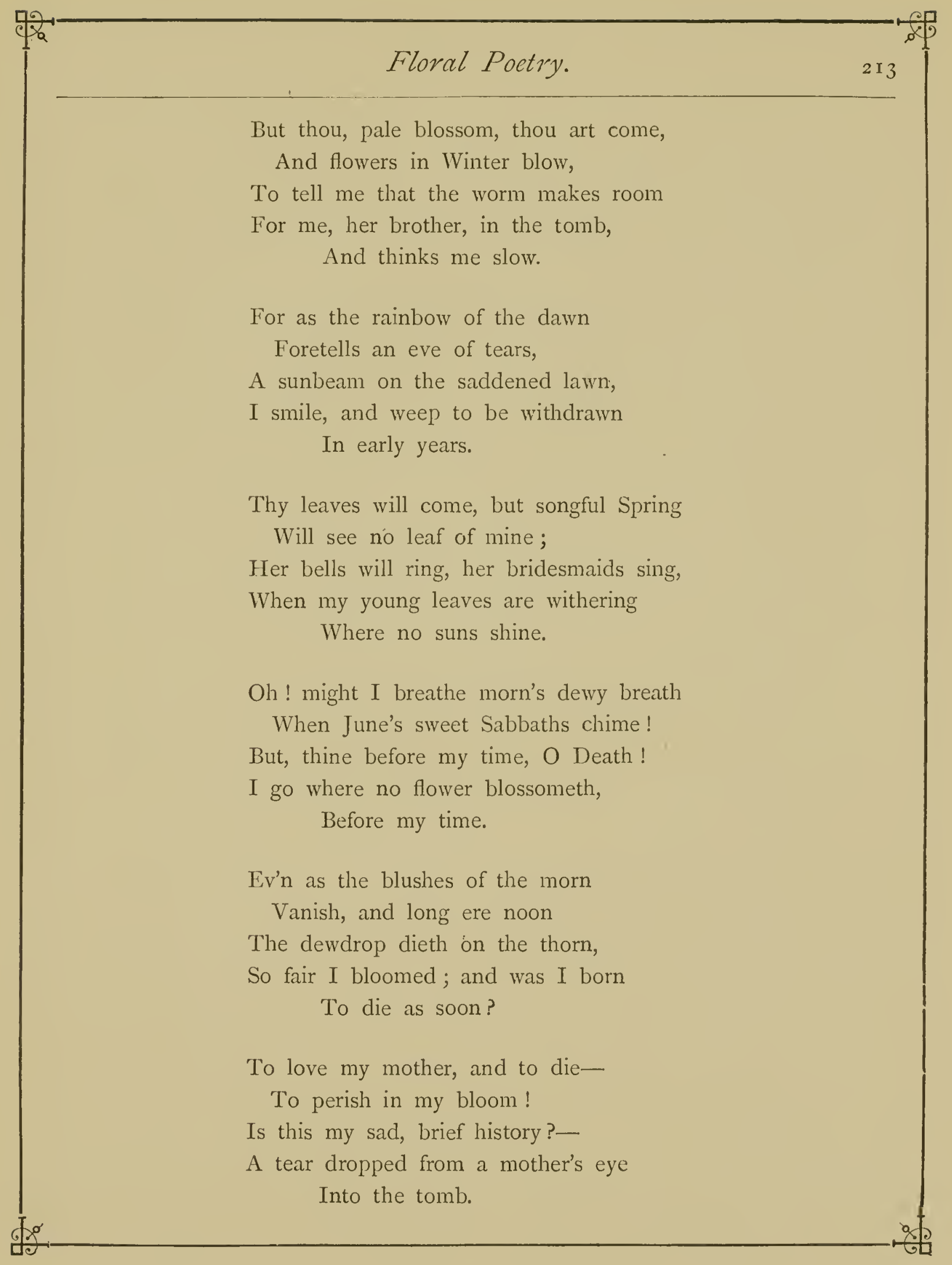




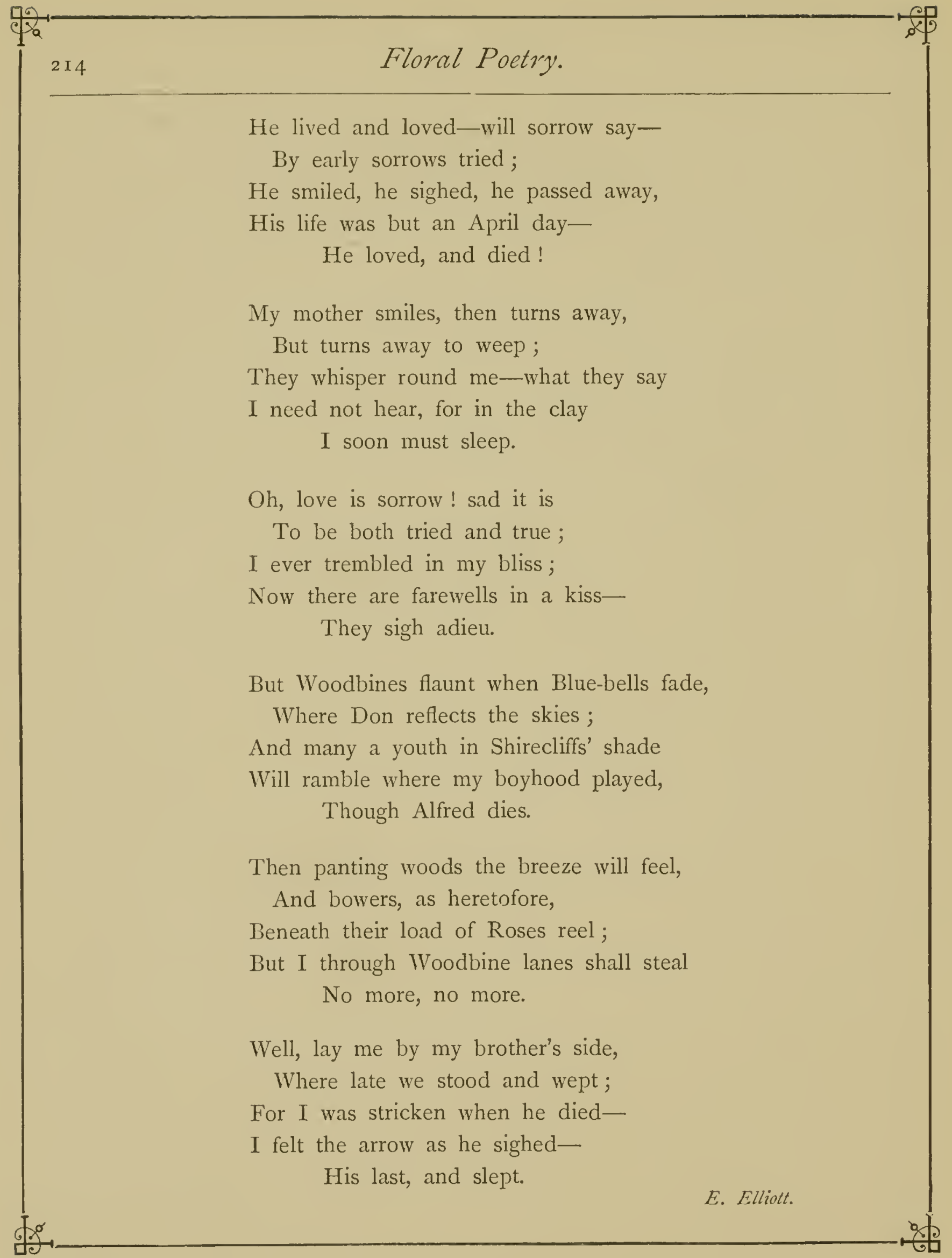




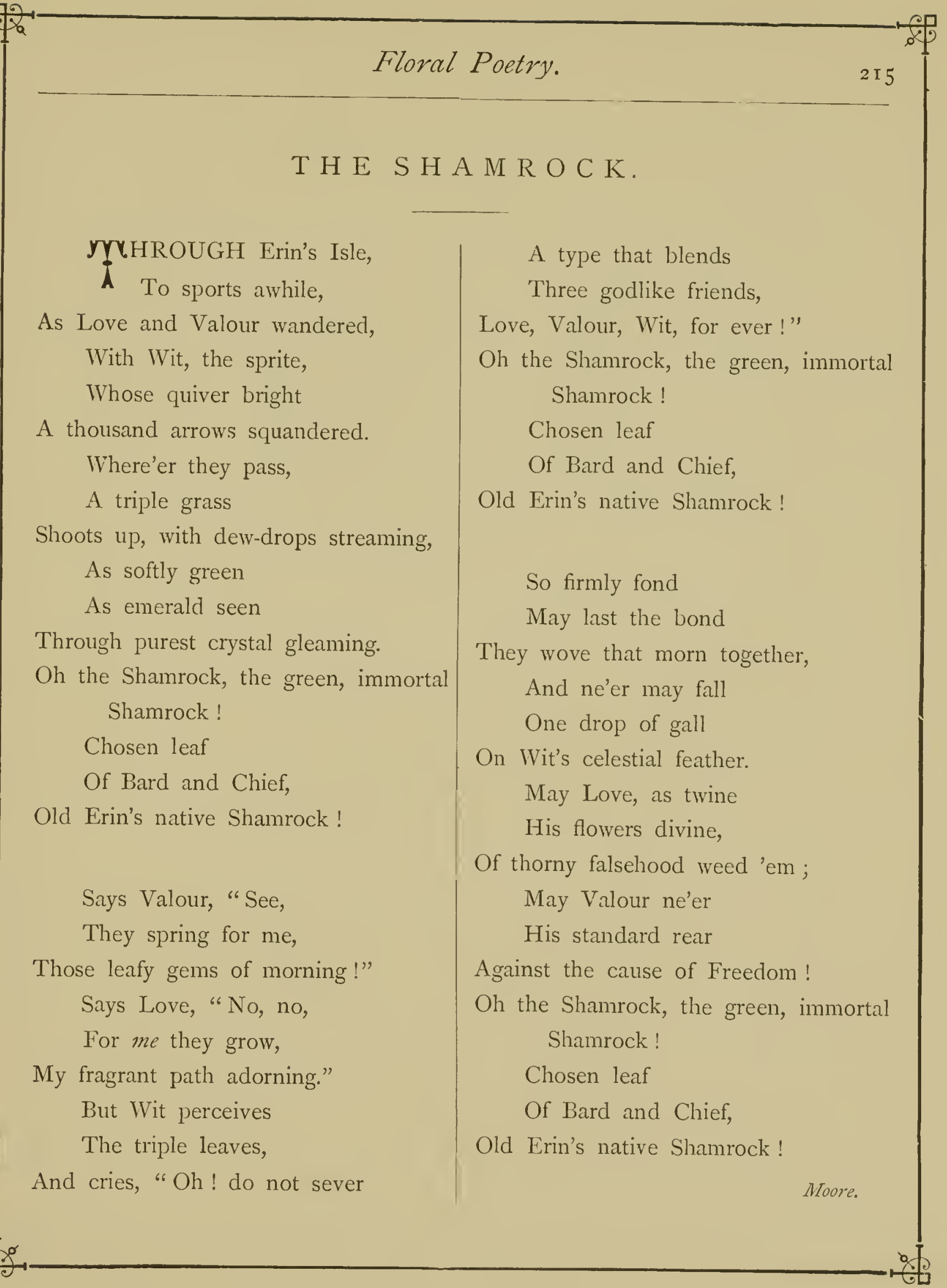




\section{ORIGIN OF THE SNOWDROP.}

MY fading flowers in Eden grew,

iX Nor Autumn's withering spread,

Among the trees, a browner hue,

To show the leaves were dead:

But through the groves and shady dells,

Waving their bright immortal bells,

Were Amaranths and Asphodels,

Undying in a place that knew

A golden age the whole year through.

But when the angel's fiery bands,

Guarding the eastern gate,

Told of a broken law's commands,

And agonies that came too late:-

With "longing, lingering" wish to stay,

And many a fond but vain delay

That could not wile her grief away,

Eve wandered aimless o'er a world

On which the wrath of God was hurled.

Then came the Spring's capricious smile,

And Summer sunlight warmed the air,

And Autumn's riches served a while

To hide the curse that lingered there;

Till o'er the once untroubled sky .

Quick driven clouds began to fly,

And moaning Zephyrs ceased to sigh,

When Winter's storms in fury burst

Upon a world indeed accurst. 


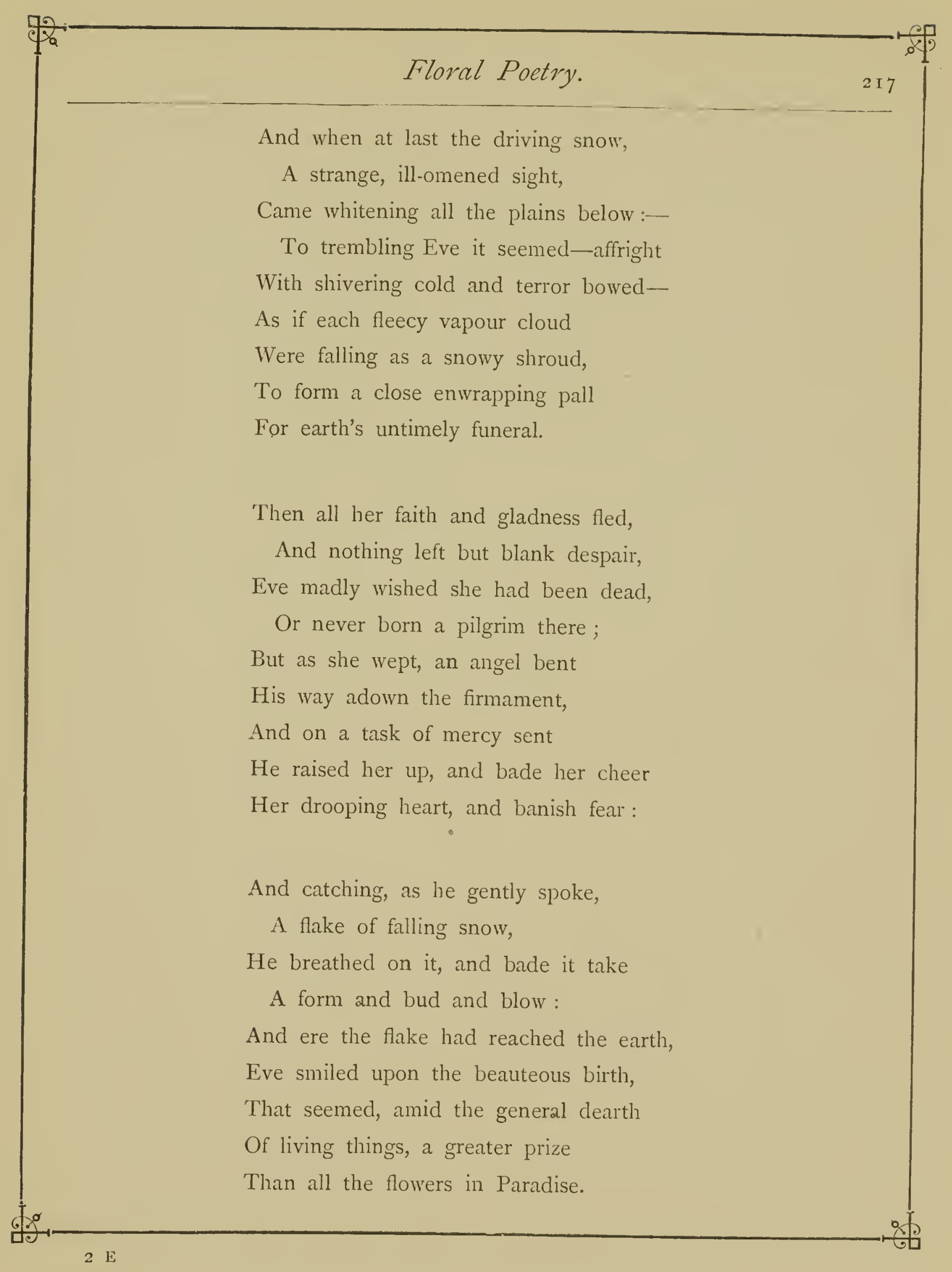




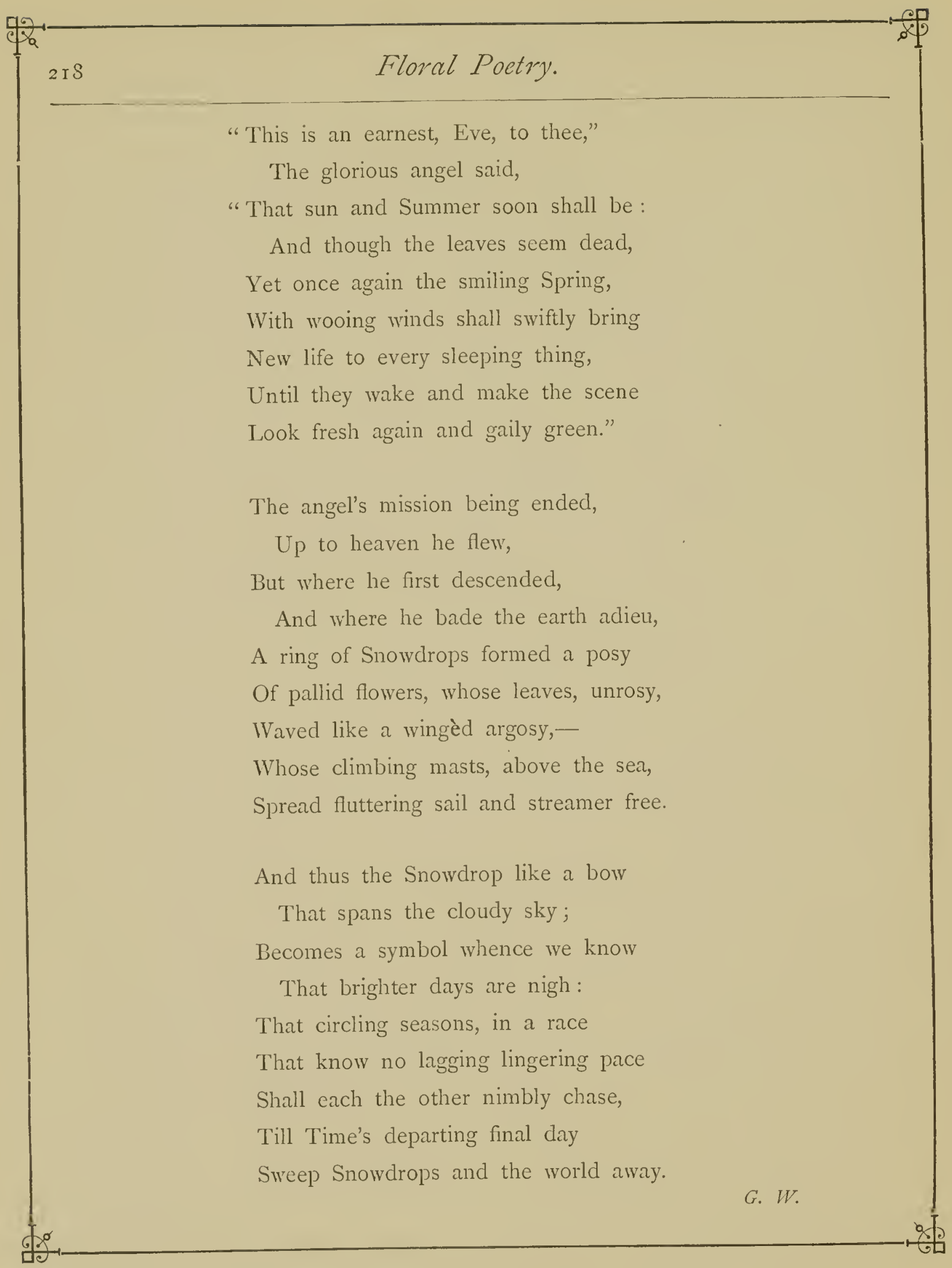




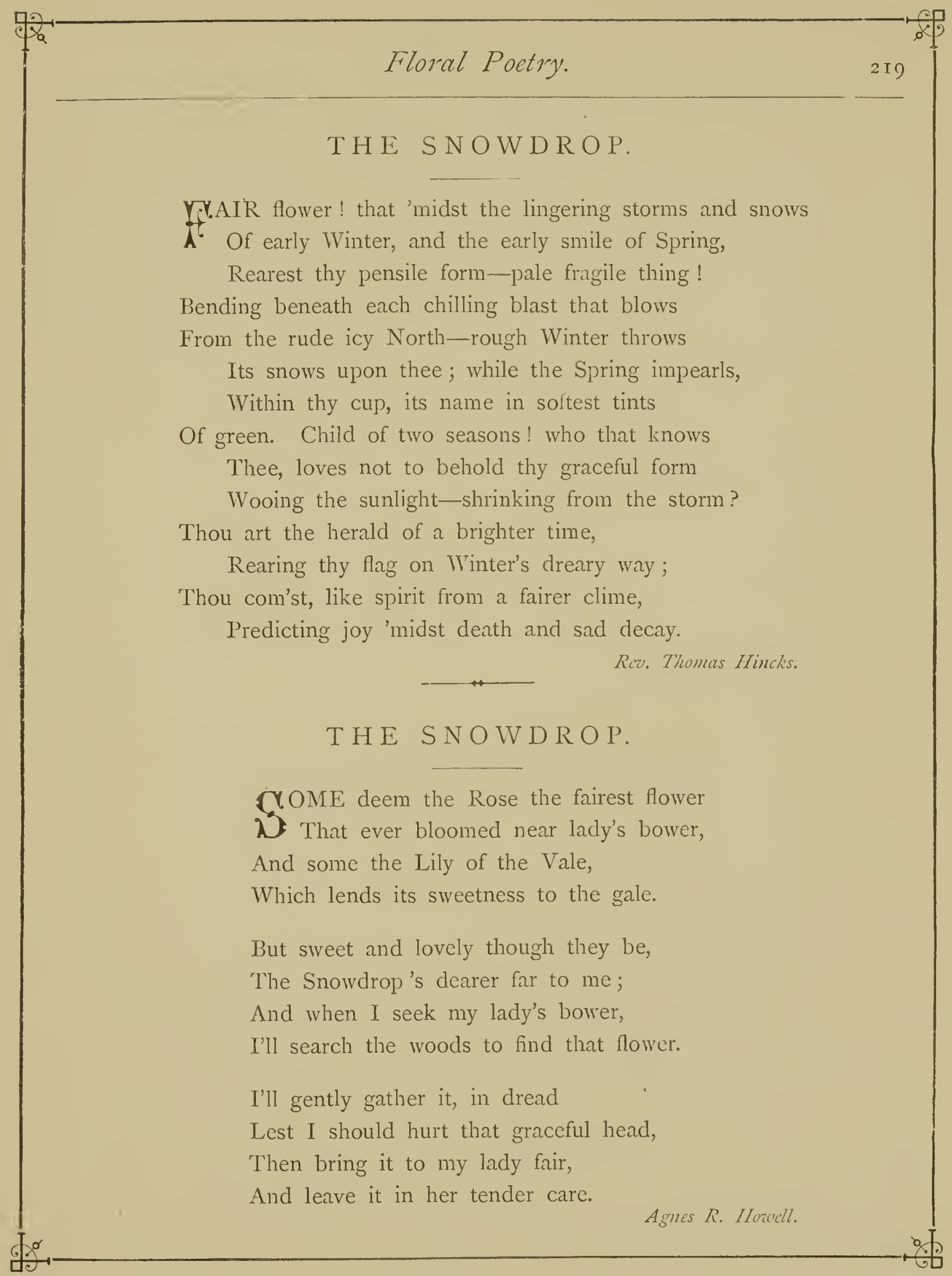




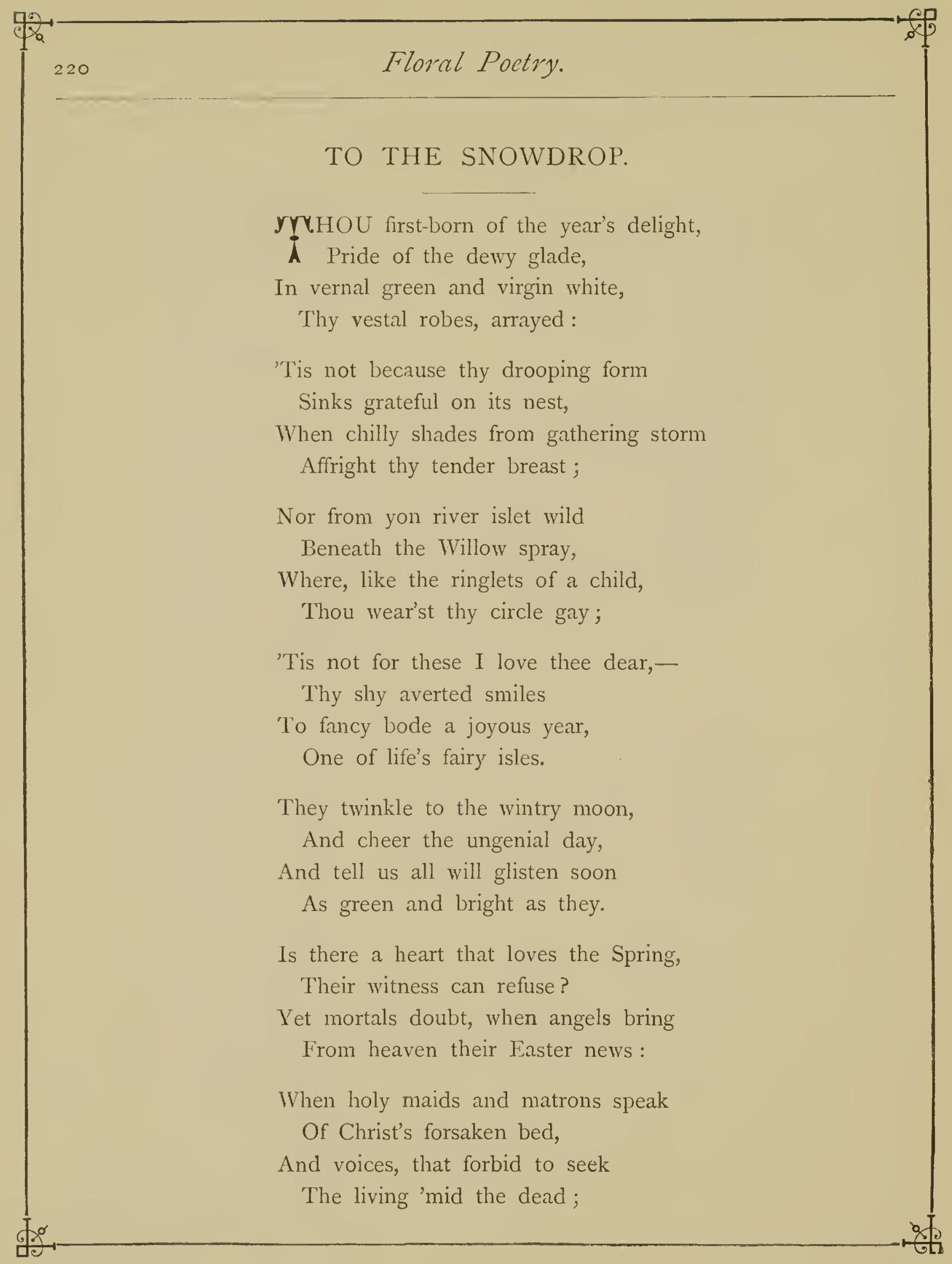




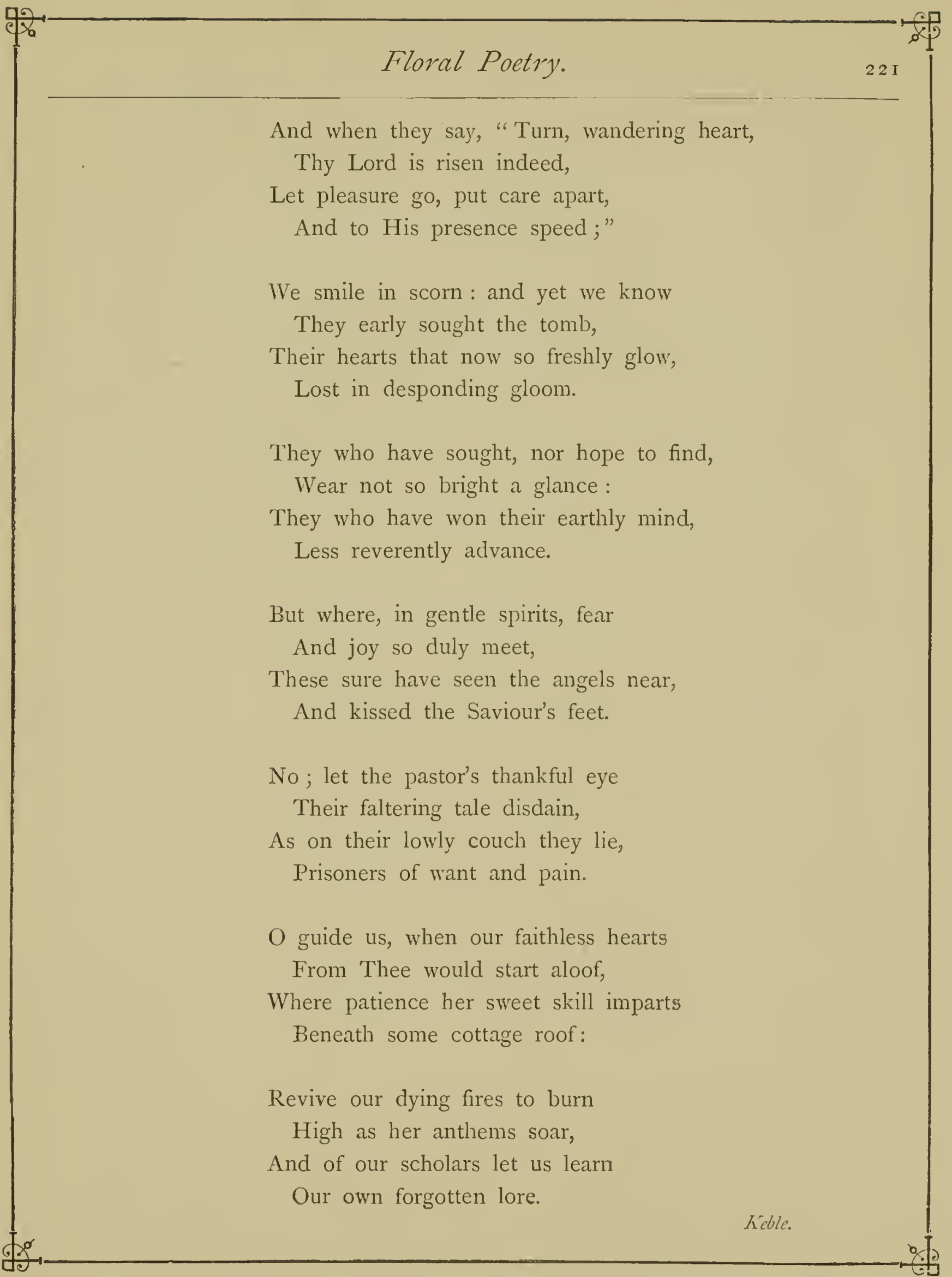




\section{TO THE SNOWDROP.}

DRETTY firstling of the year!

Herald of the host of flowers!

Hast thou left thy cavern drear,

In the hope of Summer hours?

Back unto thy earthen bowers,

Back to thy warm world below,

Till the strength of suns and showers

Quell the now relentless snow!

Art still here?-Alive, and blithe?

Though the stormy night hath fled,

And the Frost hath passed his scythe

O'er thy small unsheltered head?

Ah! some lie amid the dead

(Many a giant stubborn tree,-

Many a plant, its spirits shed),

That were better nursed than thee!

What hath saved thee? Thou wast not

'Gainst the arrowy Winter furred-

Armed in scale-but all forgot

When the frozen winds were stirred.

Nature, who doth clothe the bird,

Should have hid thee in the earth,

Till the cuckoo's song was heard,

And the Spring let loose her mirth.

Nature-deep and mystic word,

Mighty mother! still unknown;

Thou didst sure the Snowdrop gird

With an armour all thine own! 


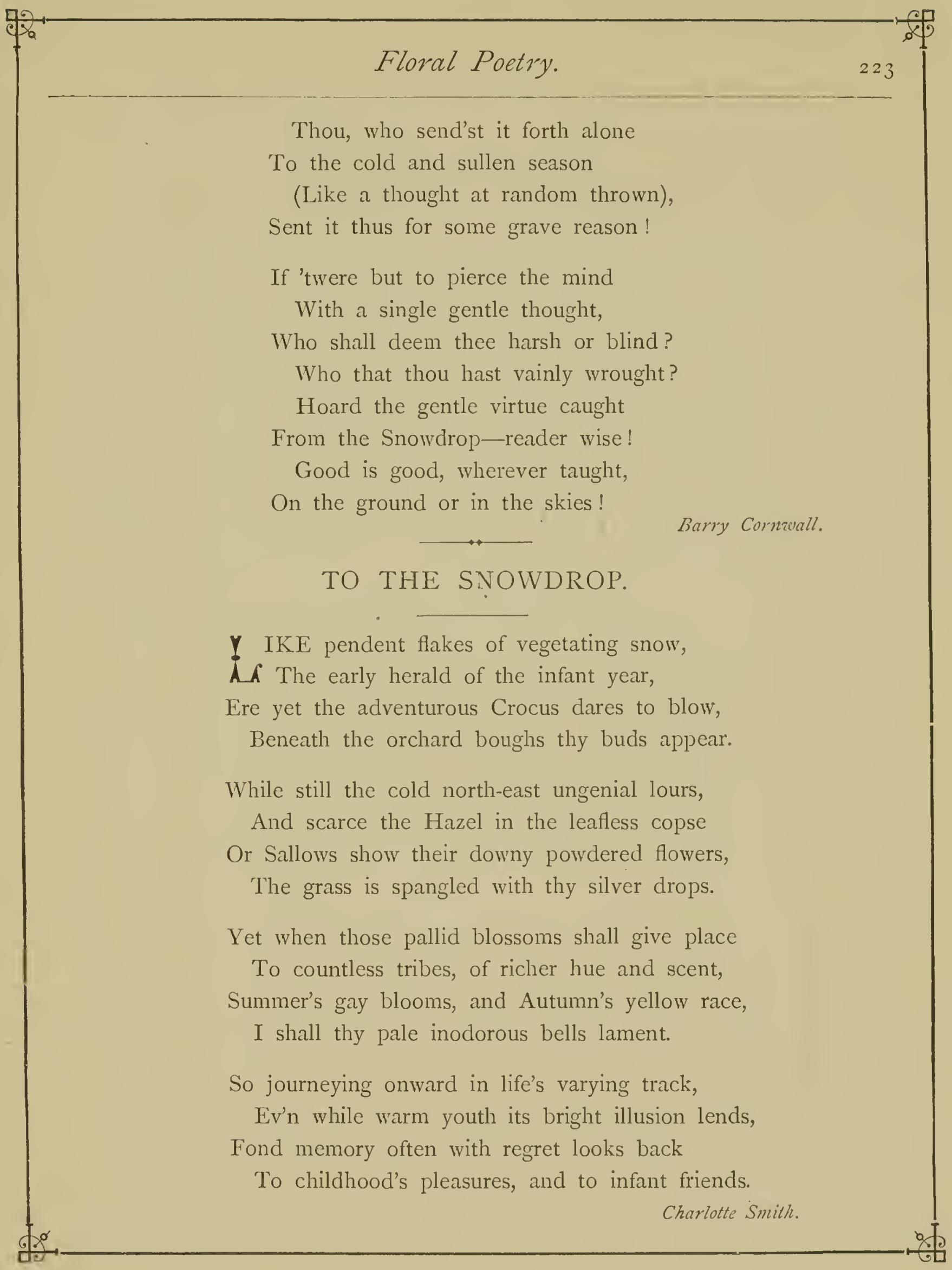




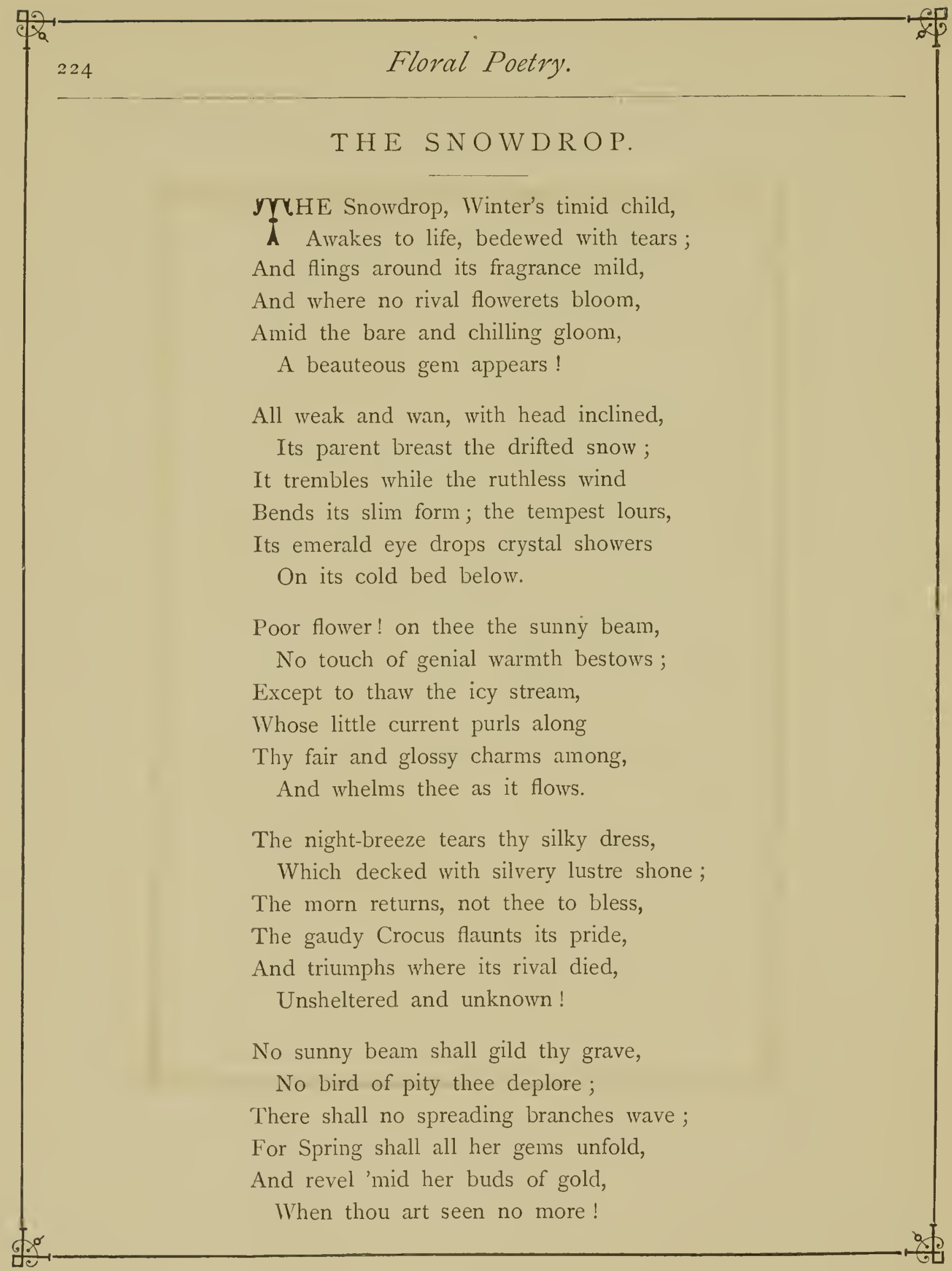




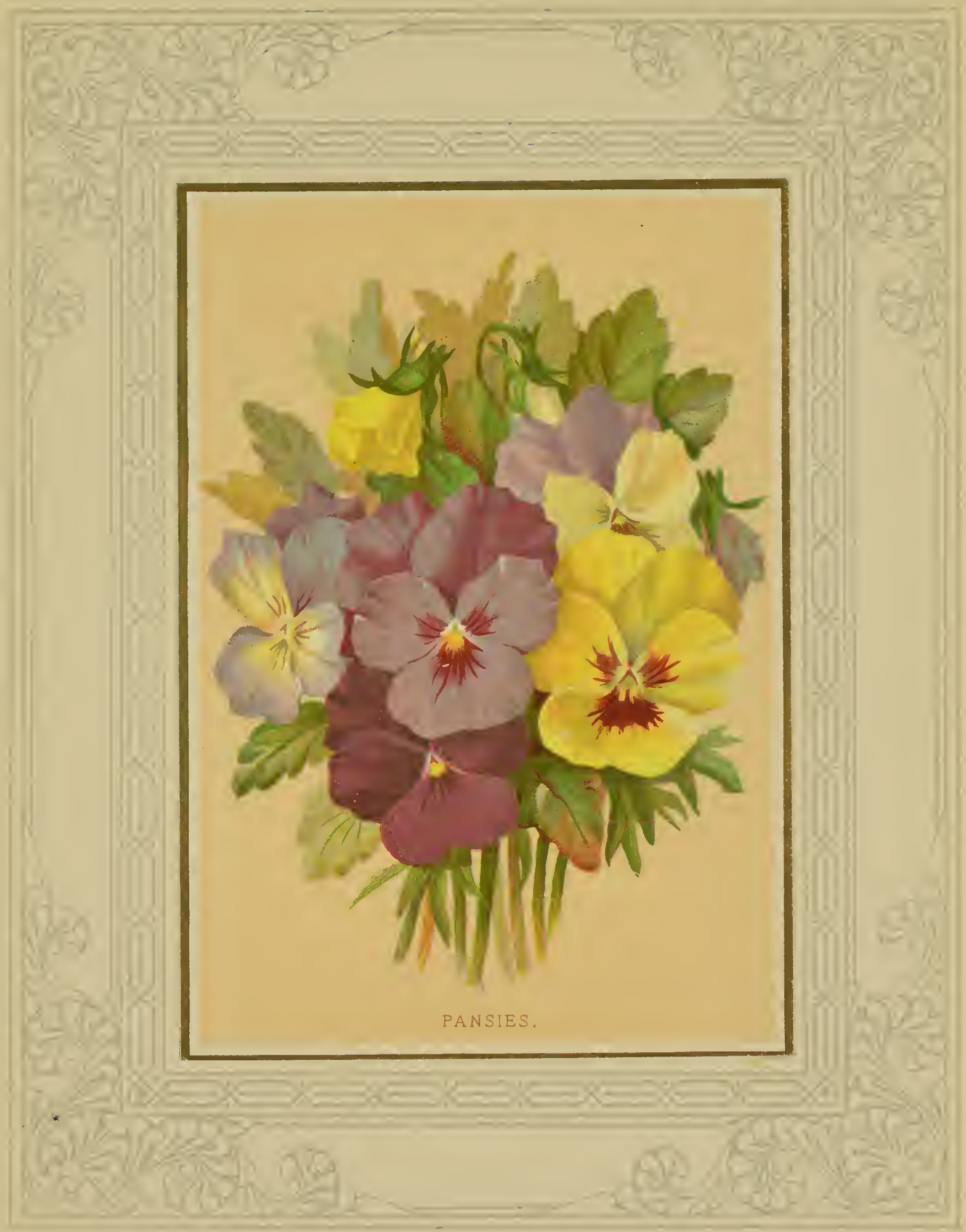


$+$ 


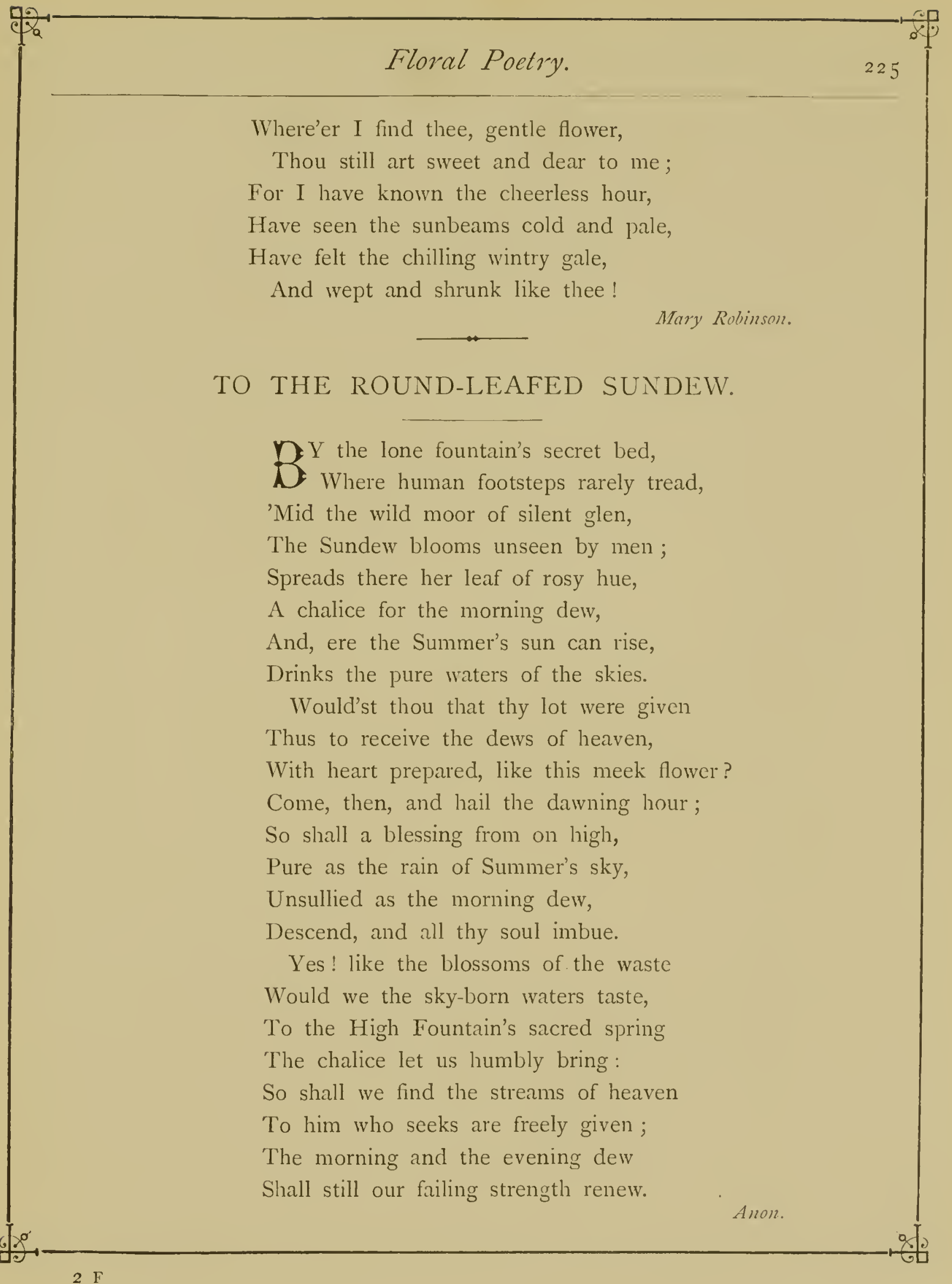




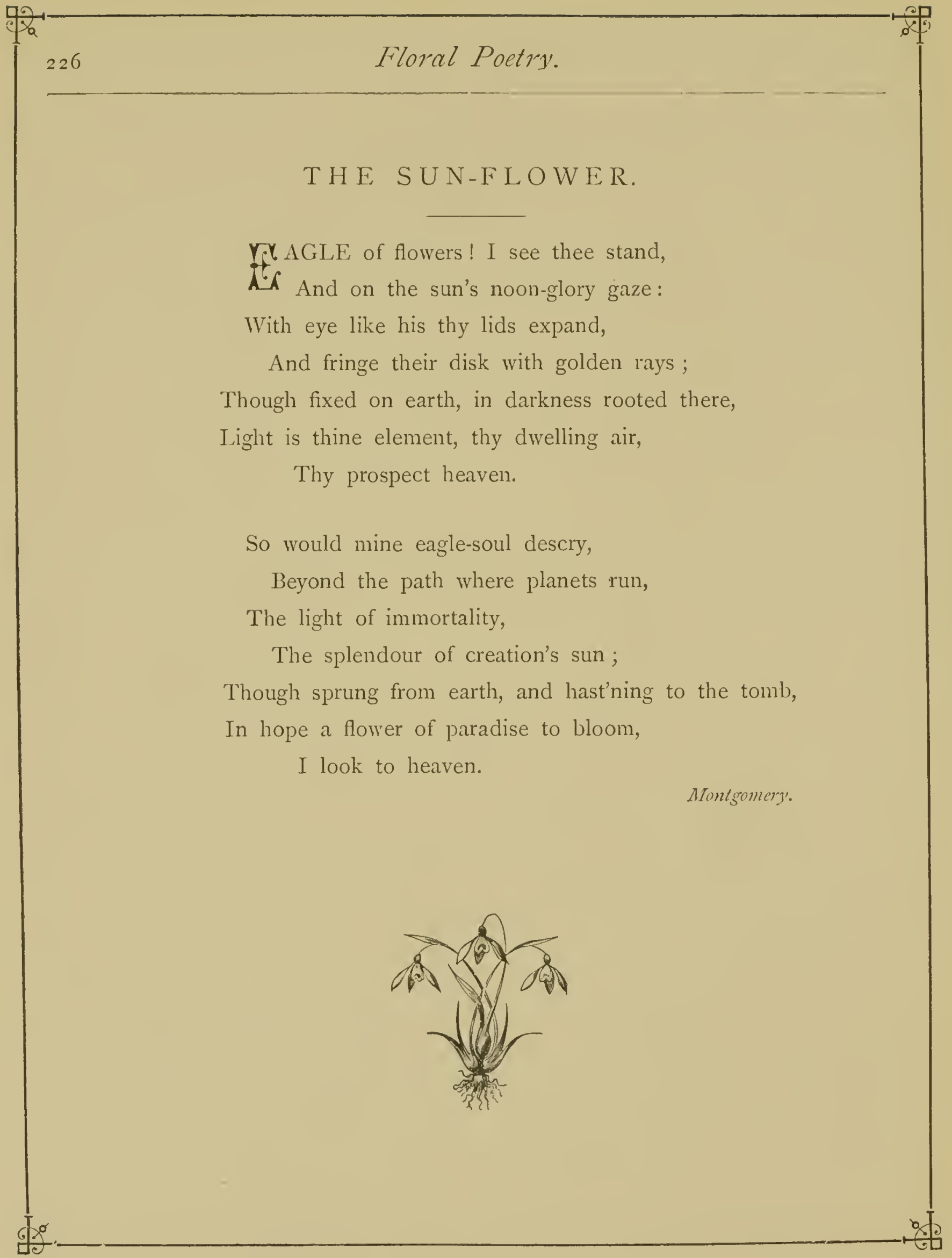




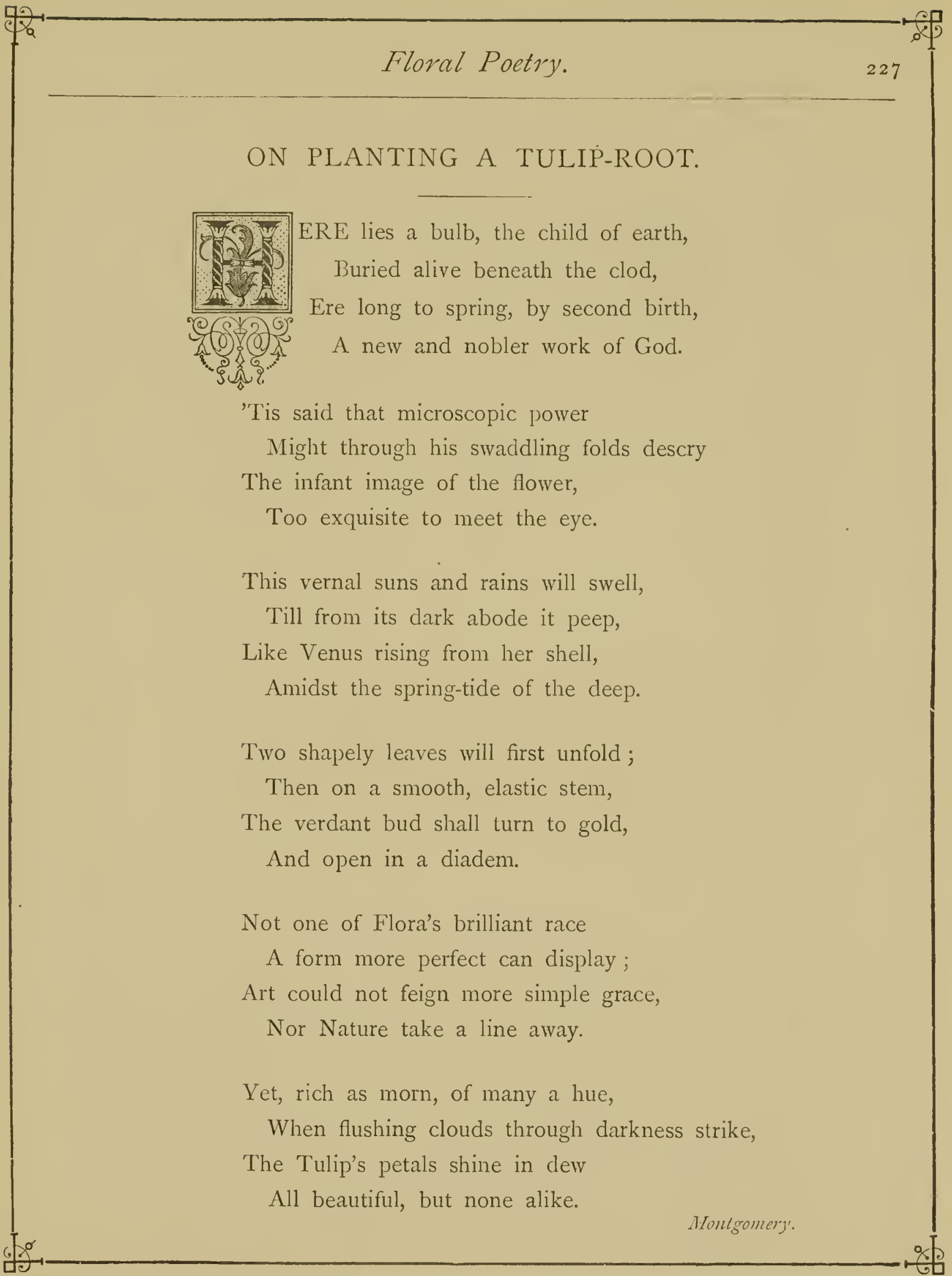




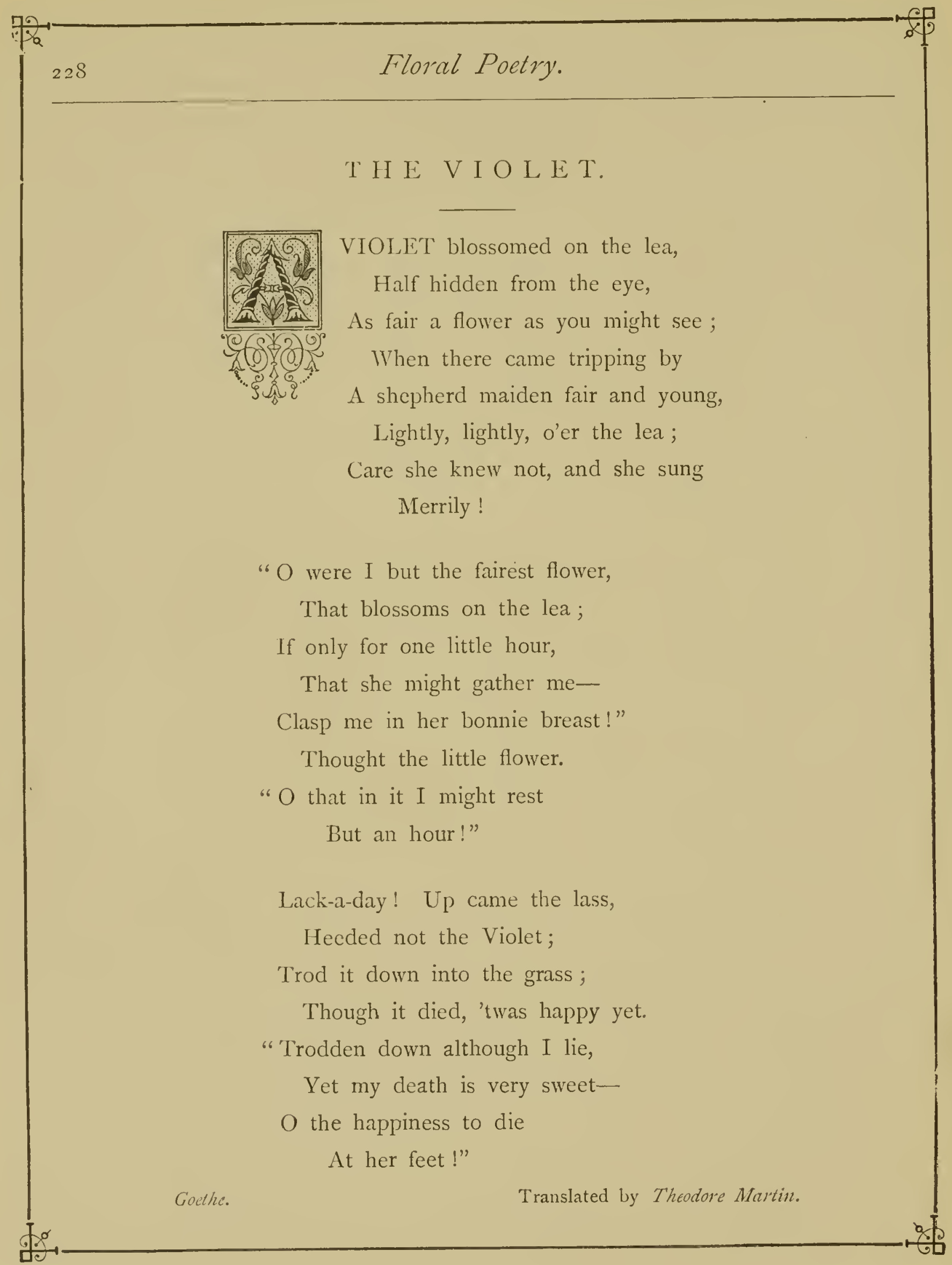




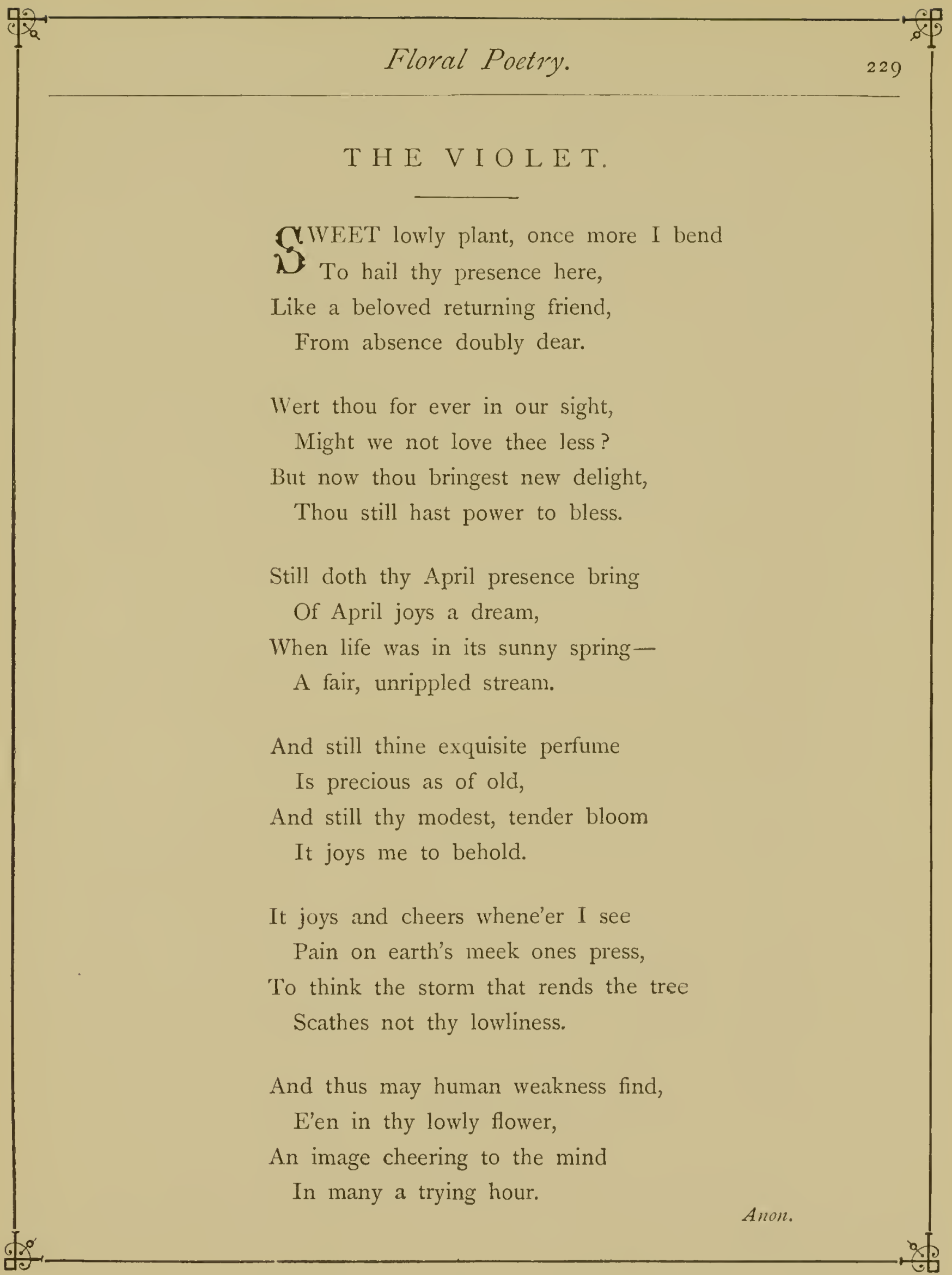




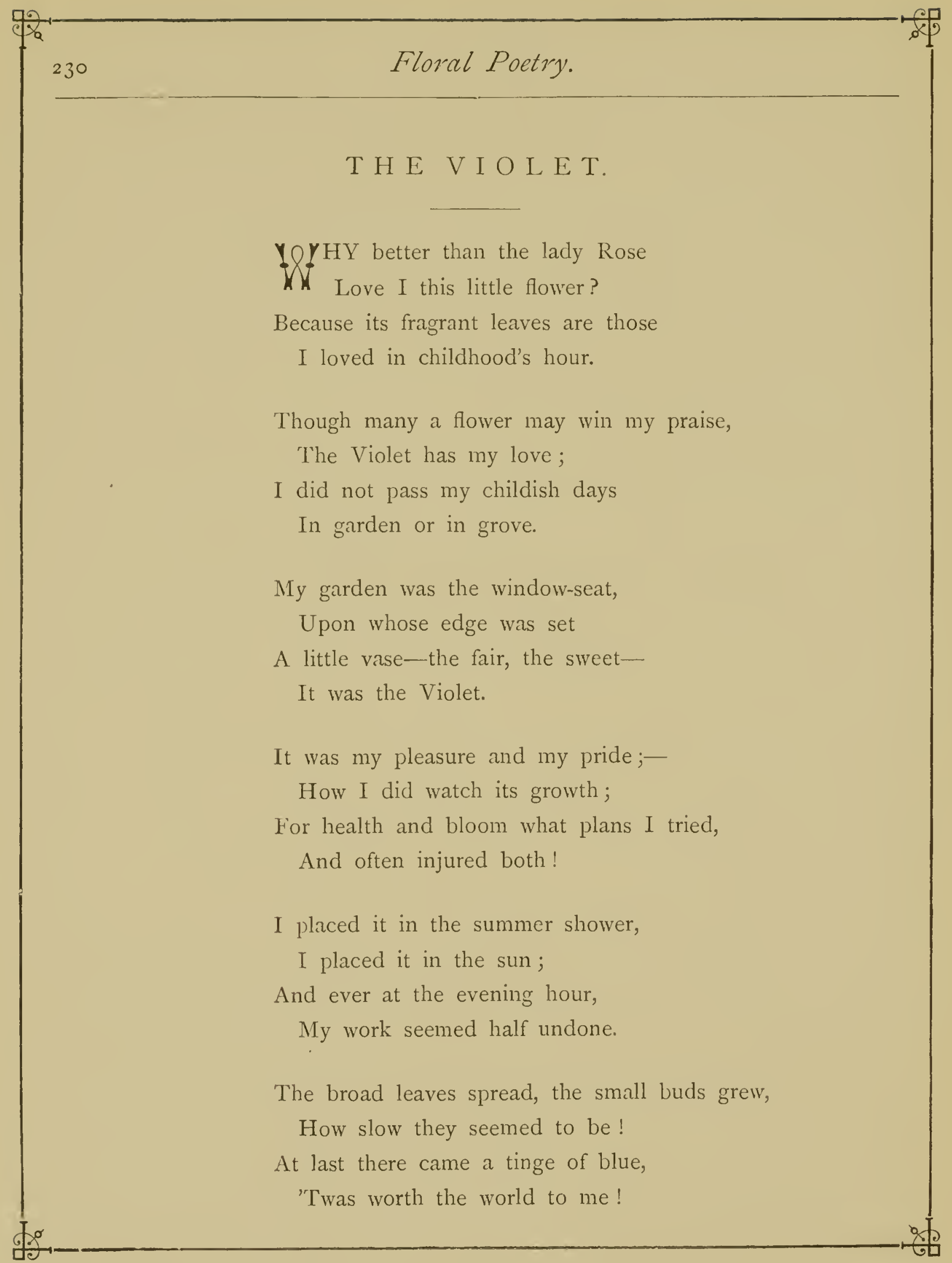




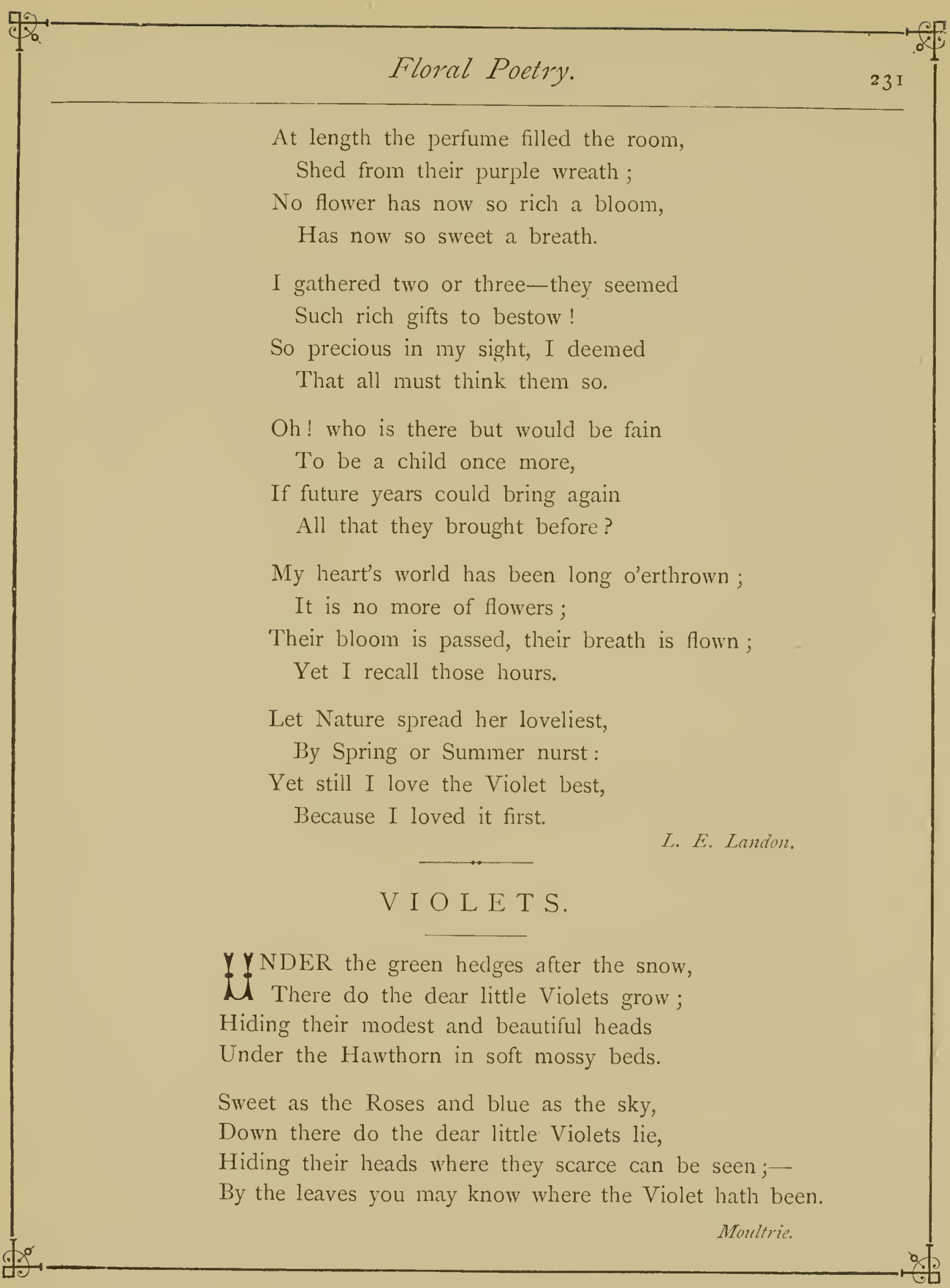


CWEET Violets, Love's paradise, that spread

2. Your gracious odours, which you couchèd bear

Within your palie faces,

Upon the gentle wing of some calm-breathing wind,

That plays amidst the plain,

If by the favour of propitious stars you gain

Such grace as in my ladie's bosom place to find,

Be proud to touch those places!

Your honours of the flowrie meads I pray,

You pretty daughters of the earth and sun.

Raleigh.

\section{VIOLETS.-A SONNET.}

EAUTIFUL are you in your lowliness:

3 Bright in your hues, delicious in your scent,

Lovely your inodest blossoms, downward bent,

As shrinking from our gaze, yet prompt to bless

The passer-by with fragrance, and express

How gracefully, though mutely eloquent,

Are unobtrusive worth and meek content,

Rejoicing in their own obscure recess.

Delightful flowerets! at the voice of Spring

Your buds unfolded to its sunbeams bright;

And, though your blossoms soon shall fade from sight,

Above your lonely birth-place birds shall sing,

And from your clustering leaves the glow-worm fling

The emerald glory of its earth-born light.

Barton. 


\section{TH E V I O L E T.}

rryet Violet in her greenwood bower,

A Where Birchen boughs with Hazels mingle,

May boast herself the fairest flower

In glen, or copse, or forest dingle.

Though fair her gems of azure hue,

Beneath the dew-drop's weight reclining,

I've seen an eye of lovelier blue,

More sweet through watery lustre shining.

The summer sun that dew shall dry,

Ere yet the day be past its morrow;

No longer in my false love's eye

Remained the tear of parting sorrow.

Sir Walter Scott.

\section{ON A FADED VIOLET.}

yrHE odour from the flower is gone

A Which, like thy kisses, breathed on me;

The colour from the flower is flown,

Which glowed of thee, and only thee!

A shrivelled, lifeless, vacant form,

It lies on my abandoned breast,

And mocks the heart, which yet is warm,

With cold and silent rest.

I weep,-my tears revive it not!

I sigh,-it breathes no more on me;

Its mute and uncomplaining lot

Is such as mine should be. 


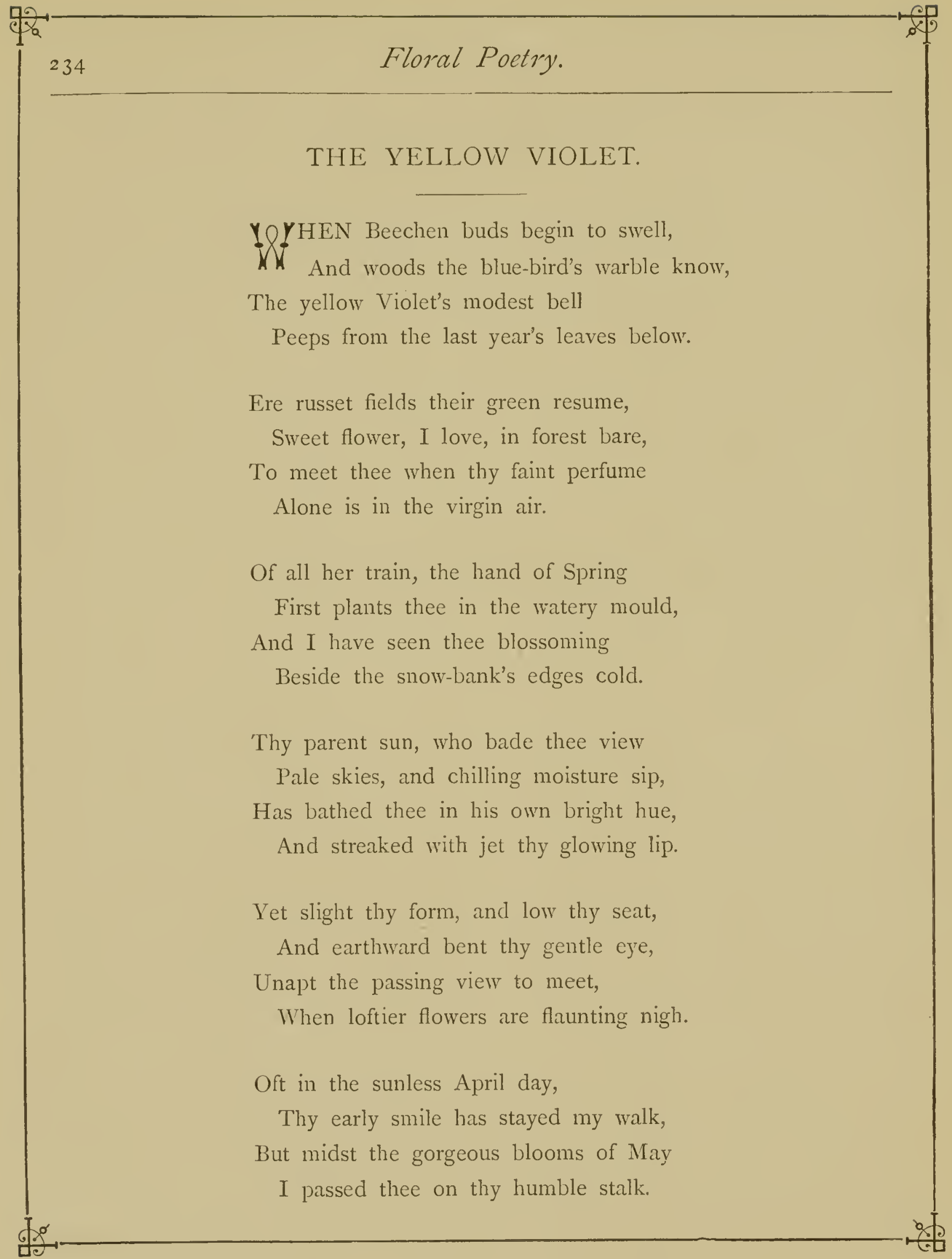




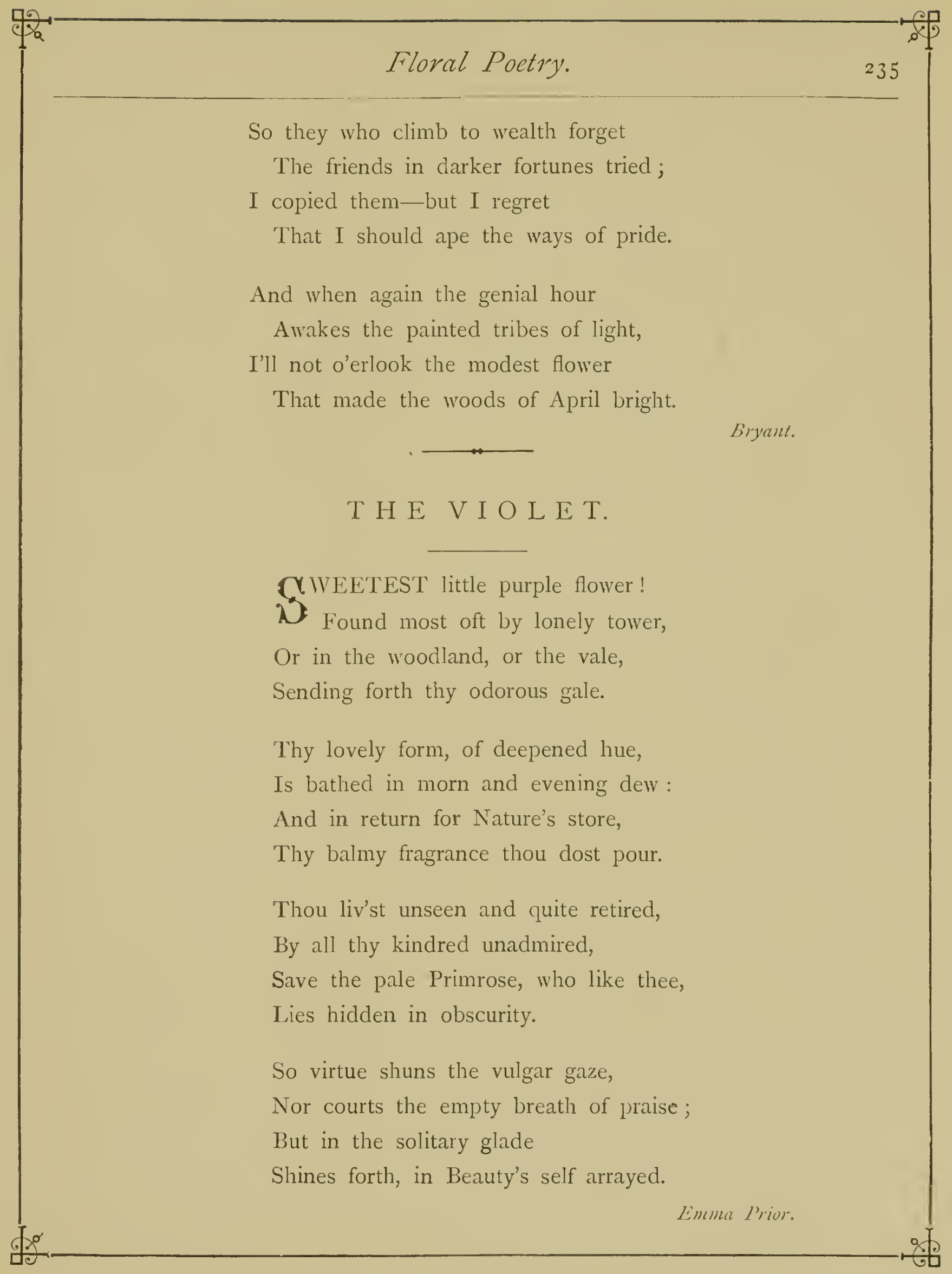




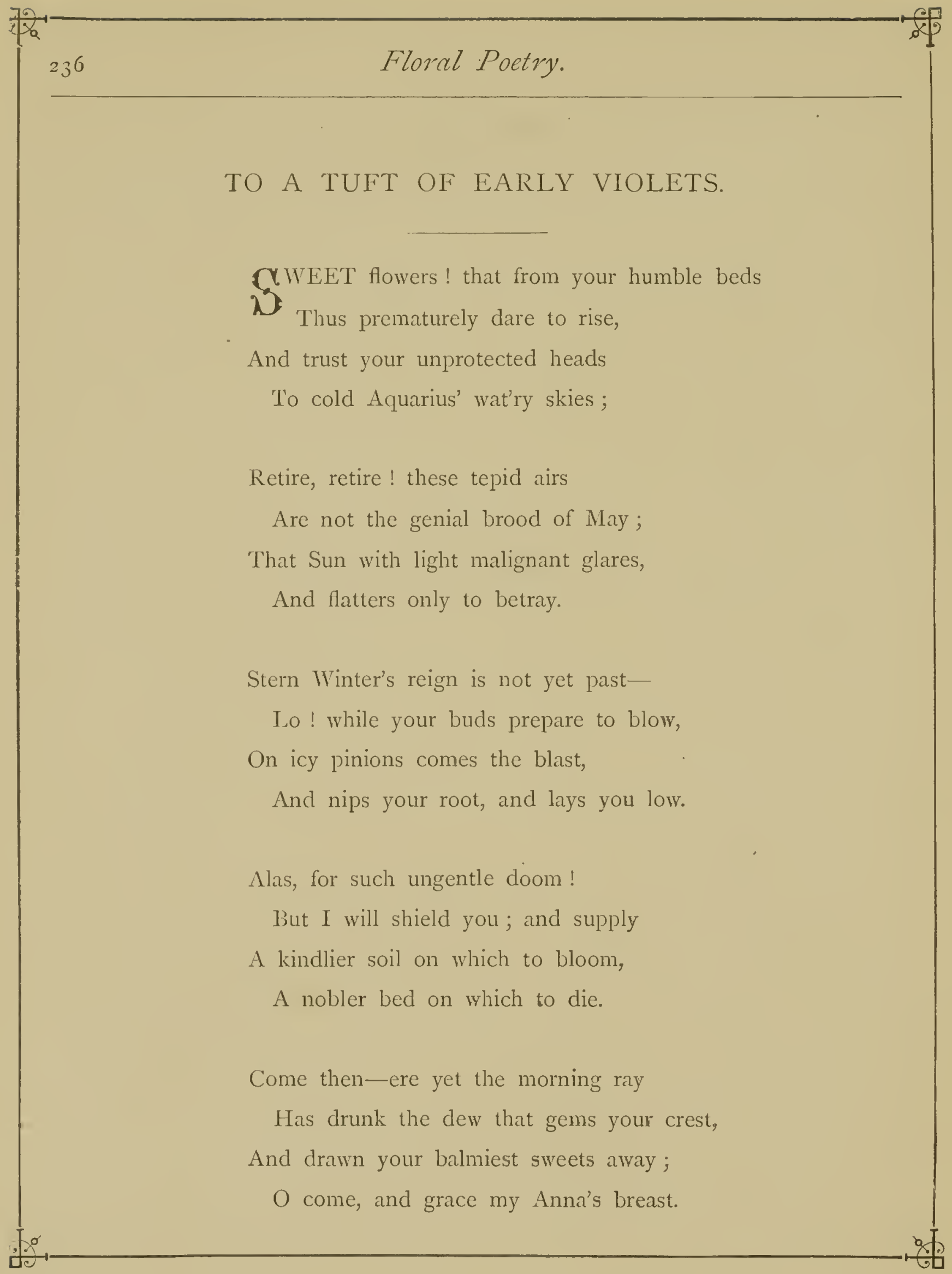




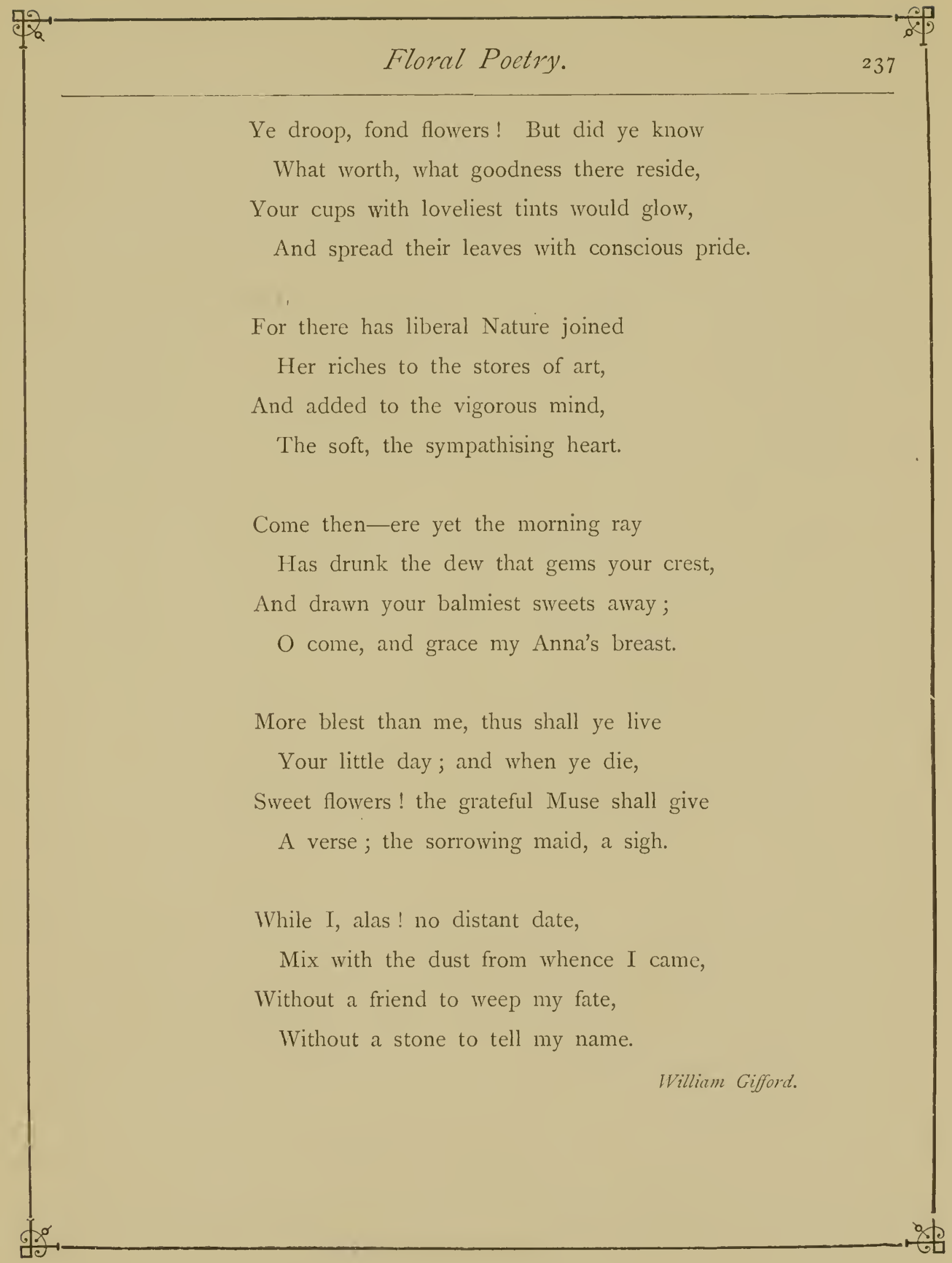




\section{THE VI O L E T.}

yrye forward Violet thus did I chide:

$\bar{\lambda}$ Sweet thief, whence did'st thou steal thy sweet that smells, If not from my love's breath? The purple pride

Which on thy soft cheek for complexion divells In my love's veins thou hast too grossly dyed,

The Lily I condemnèd for thy hand, And buds of Marjoram had stolen thy hair:

The Roses fearfully on thorns did stand, One blushing shame, another white despair;

A third, nor red nor white, had stolen of both, And to his robbery had annexed thy breath;

But, for his theft, in spite of all his growth, A vengeful canker ate him up to death.

More flowers I noted, yet I none could see

But sweet or colour it had stolen from thee.

Shakspere.

\section{THE SCENTLESS VIOLET.} ECEITFUL plant! from thee no odours rise,
Perfume the air, or scent the mossy glade, Although thy blossoms wear the modest guise Of her, the sweetest offspring of the shade.

Yet not like hers, still shunning to be seen, And by their fragrant breath, alone, betrayed, Veiled in the vesture of a scantier green,

To every gazer are thy flowers displayed.

Thus Virtue's garb Hypocrisy may wear,

Kneel as she kneels, or give as she has given; But, ah! no meek, retiring worth is there-

No incense of the heart exhales to Heaven.

C. H. Townsend. 


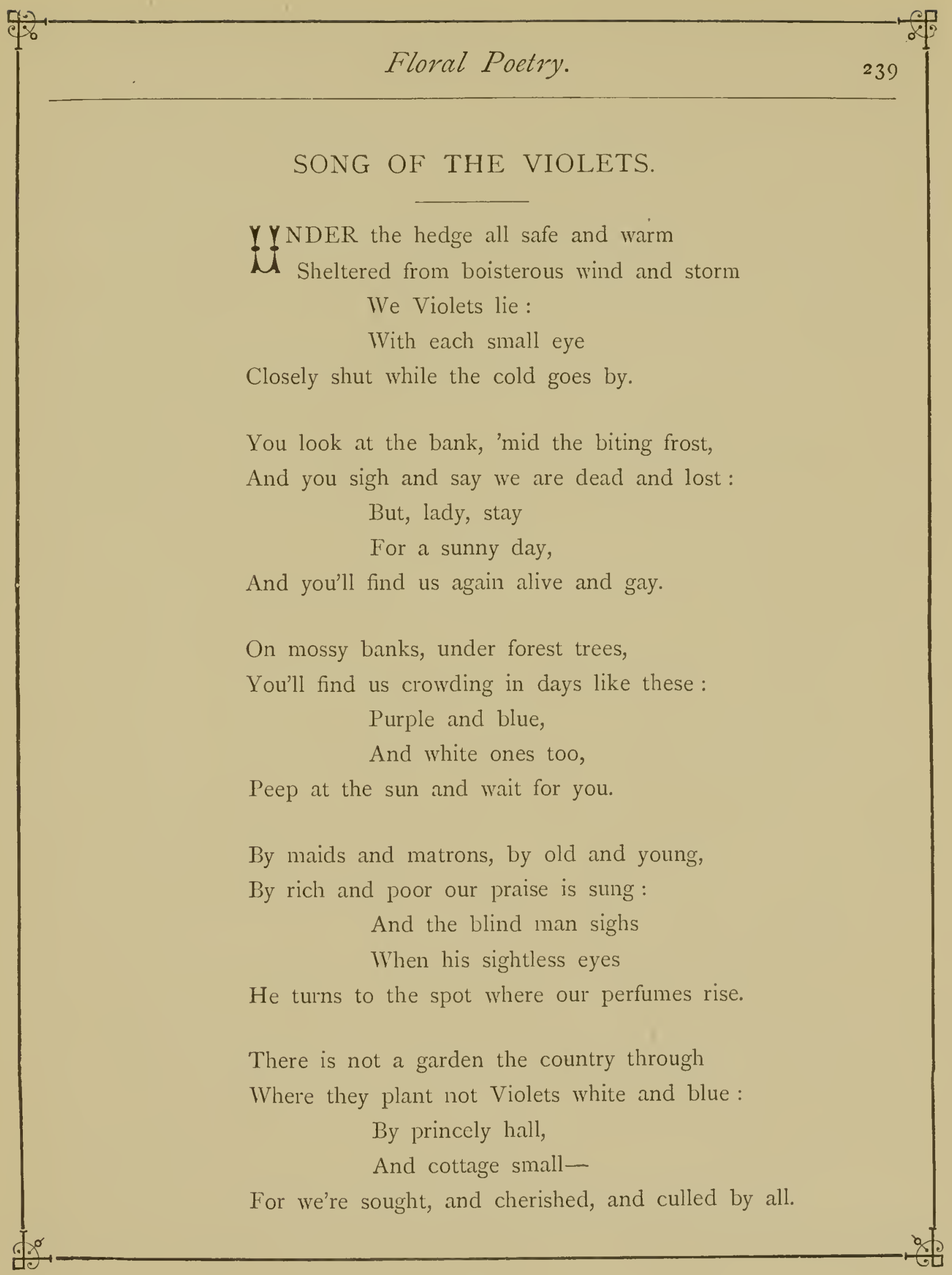




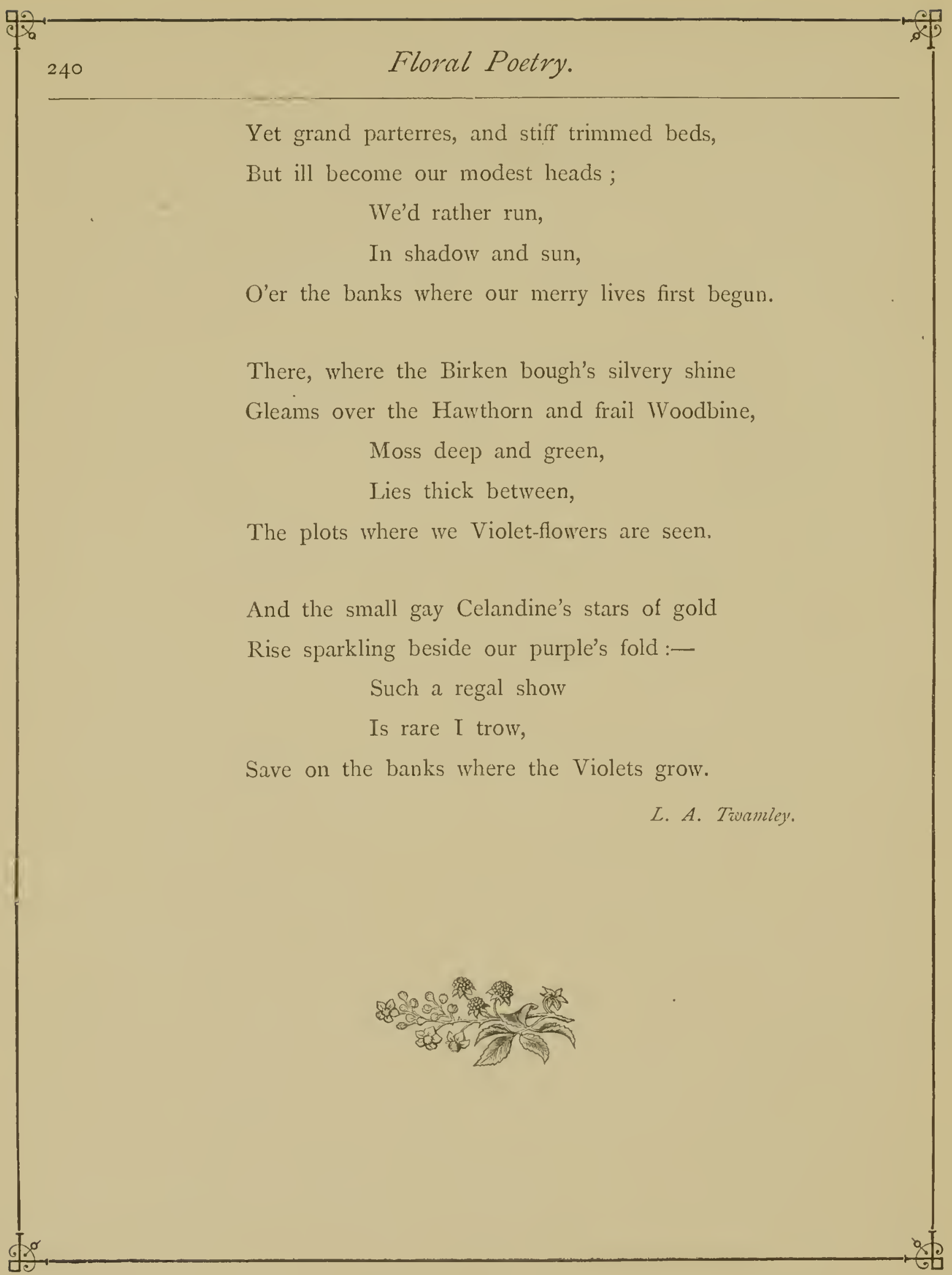




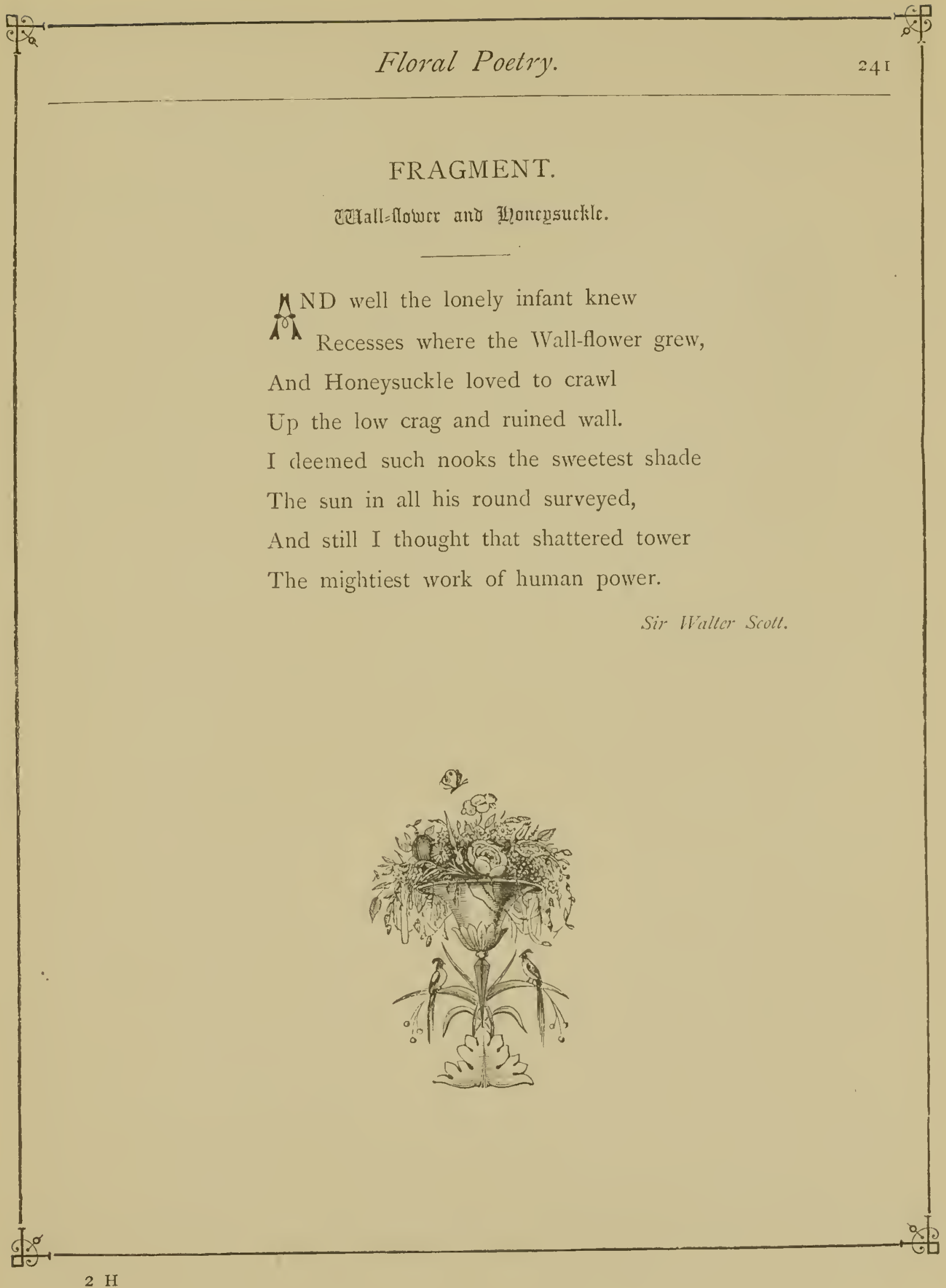




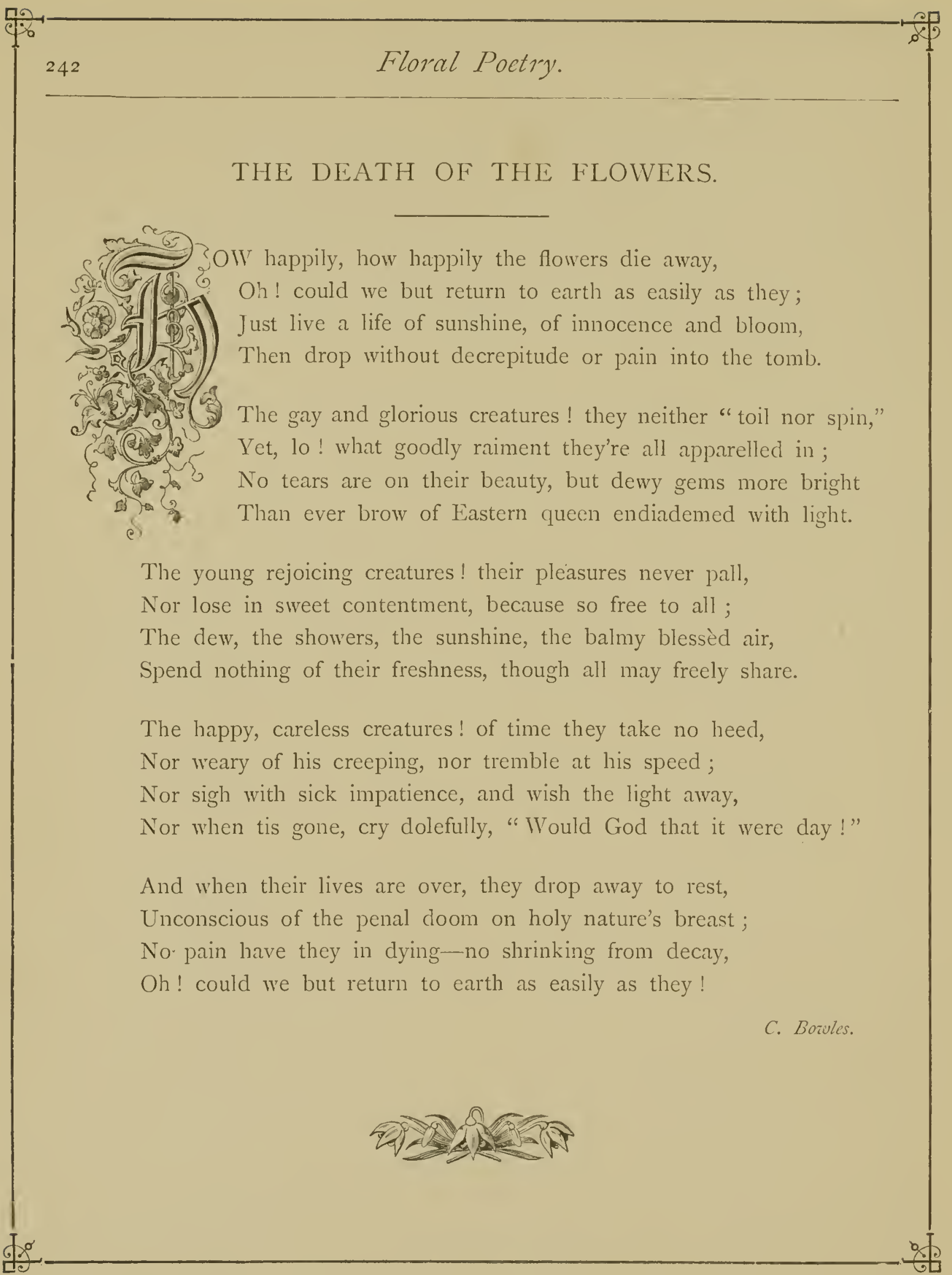




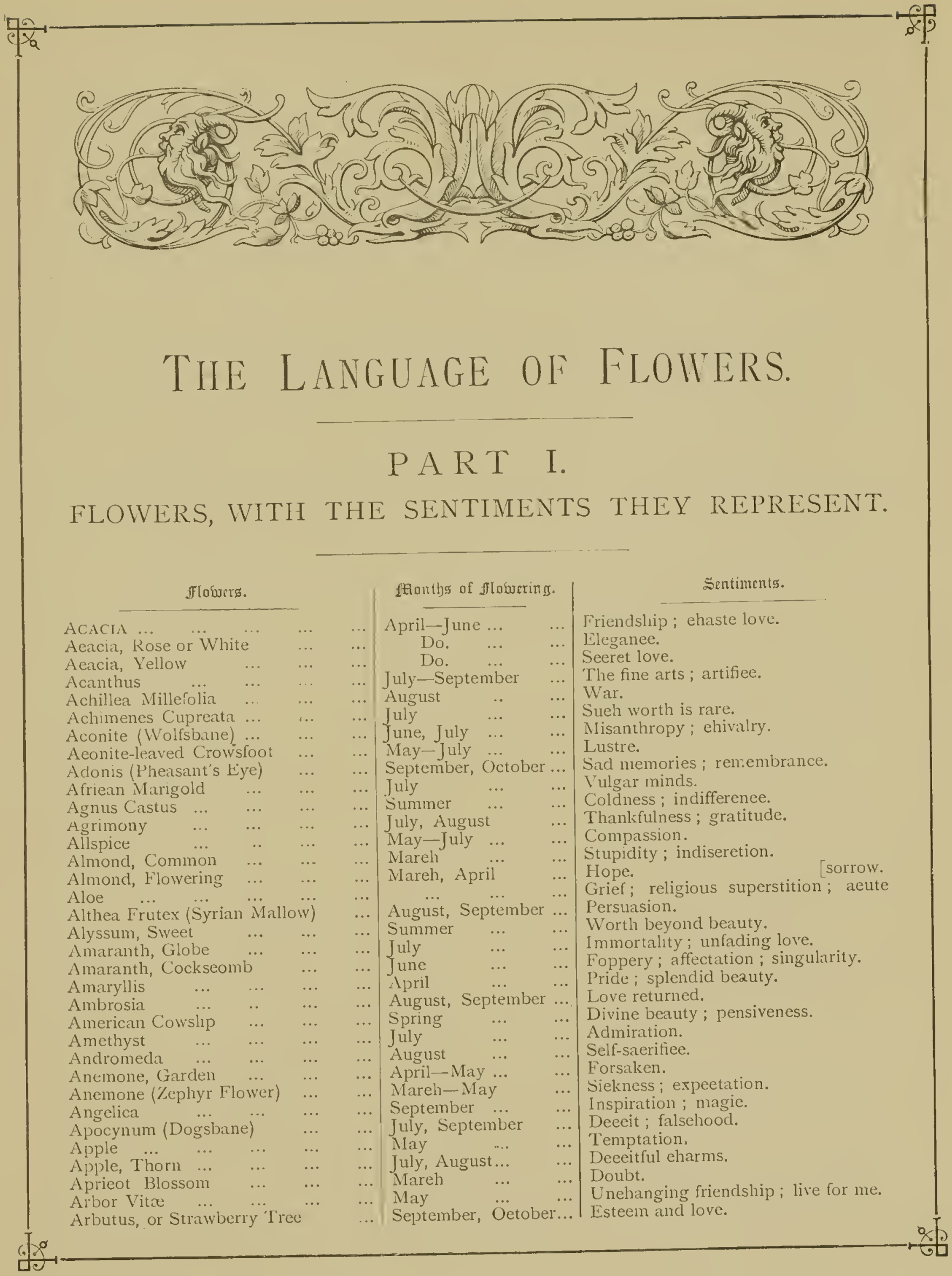




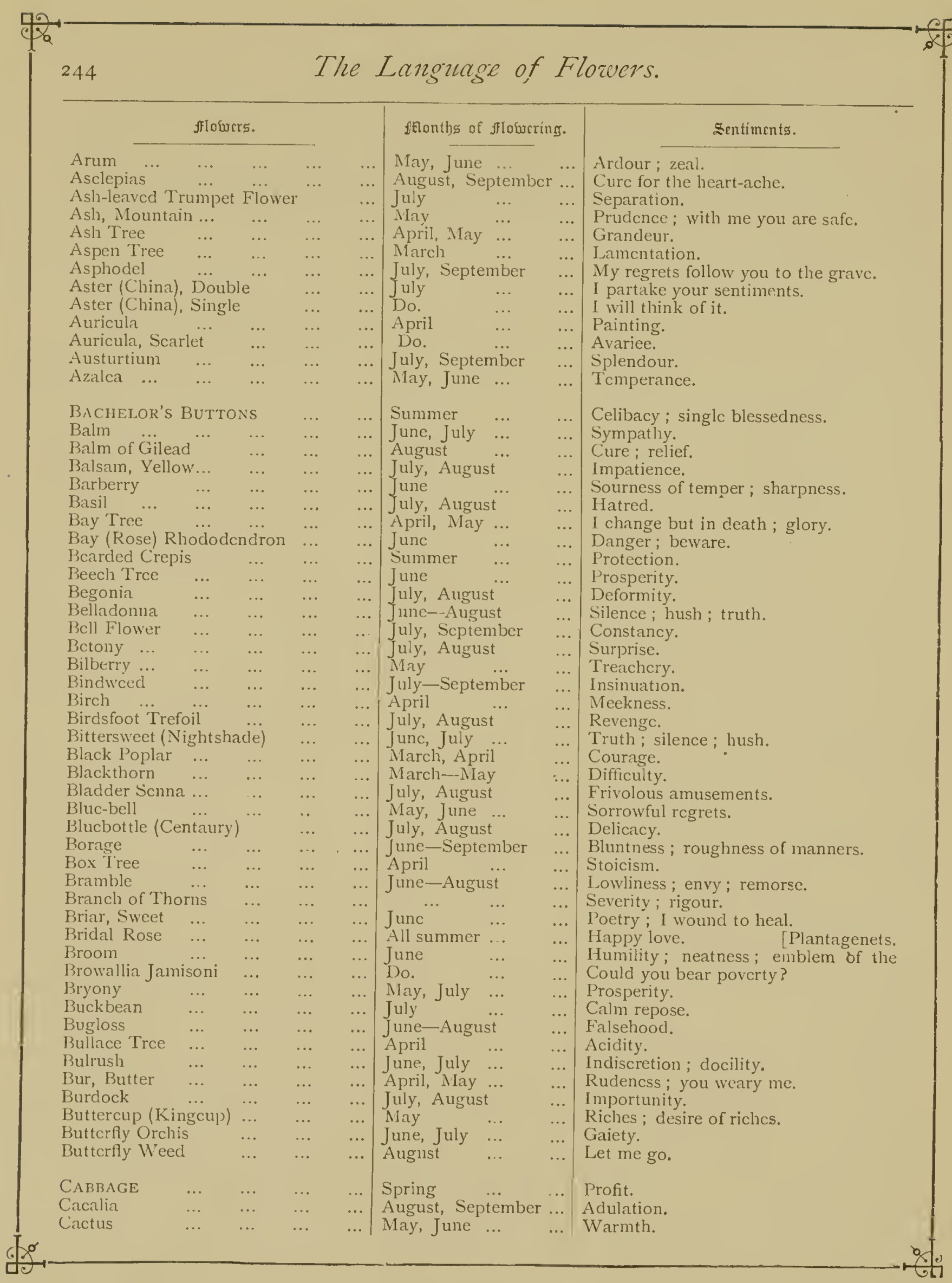




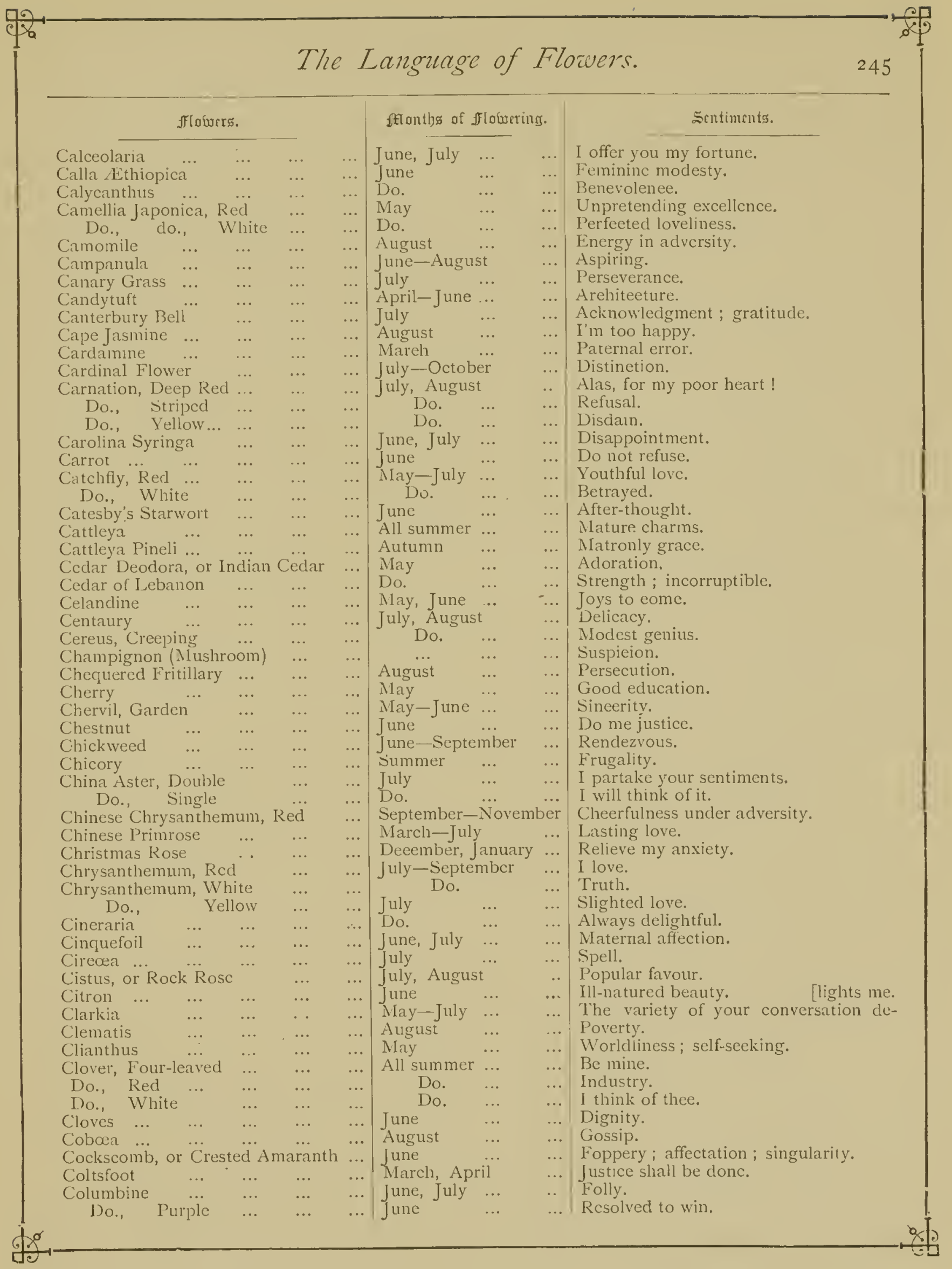




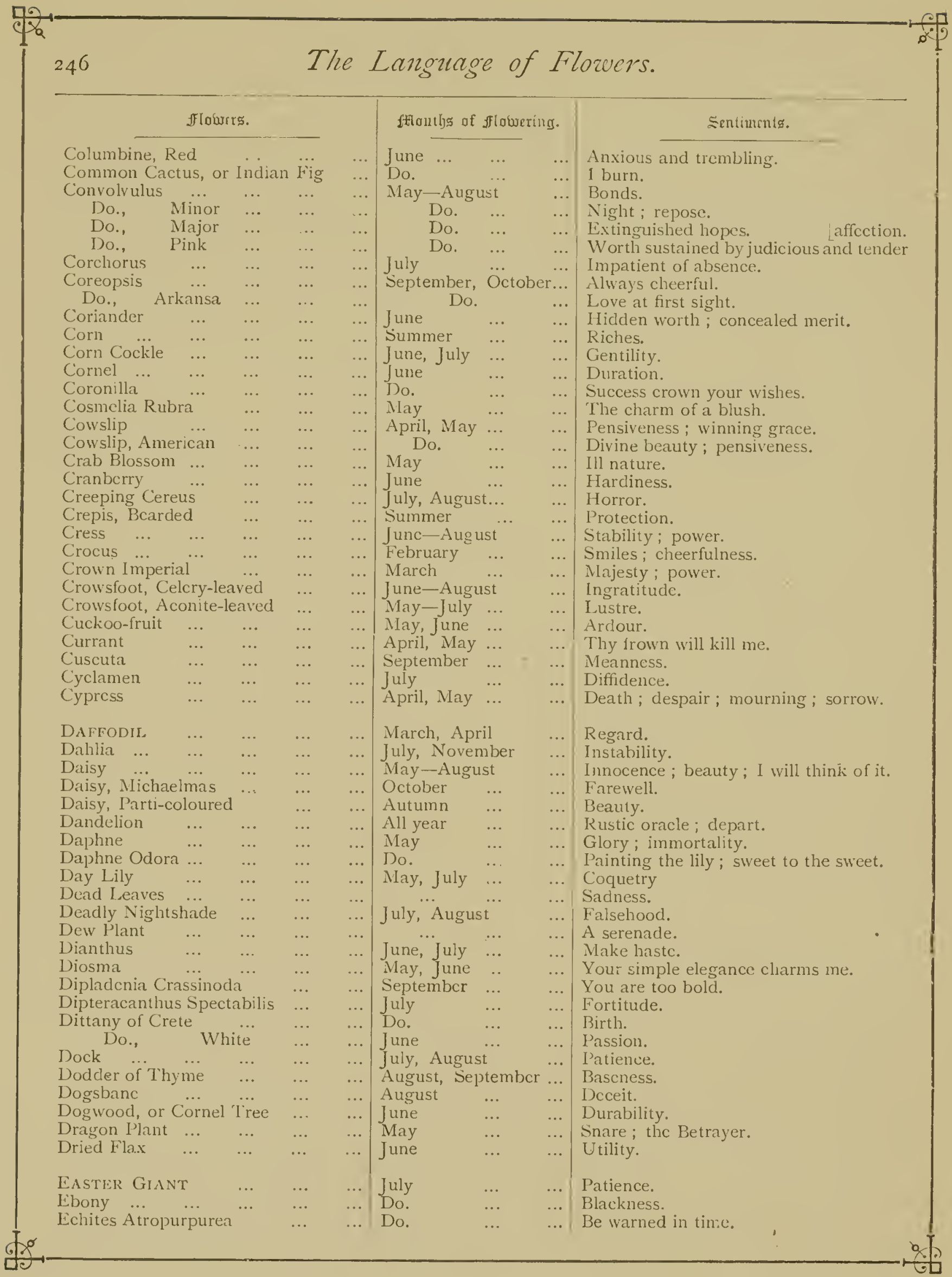




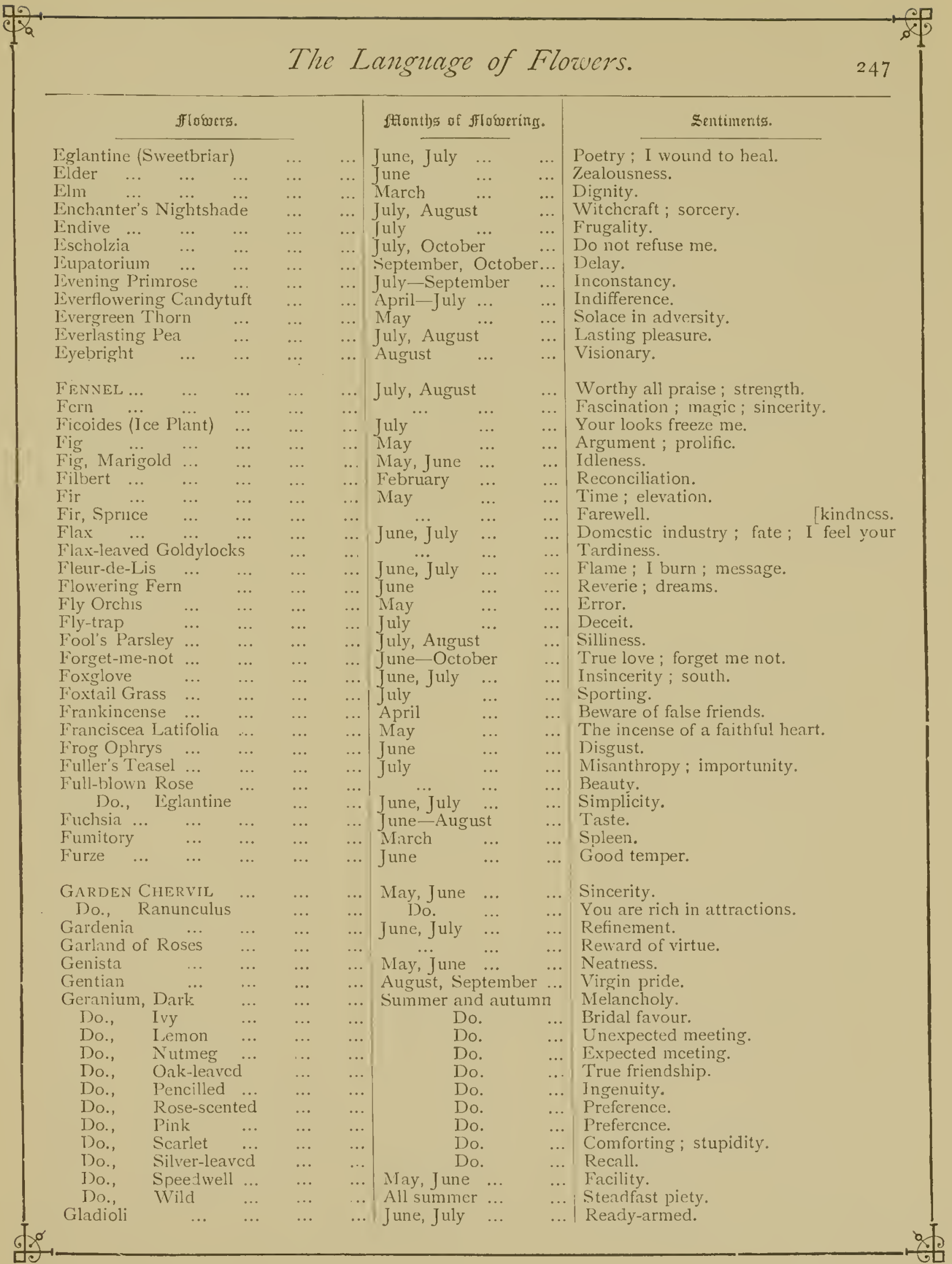




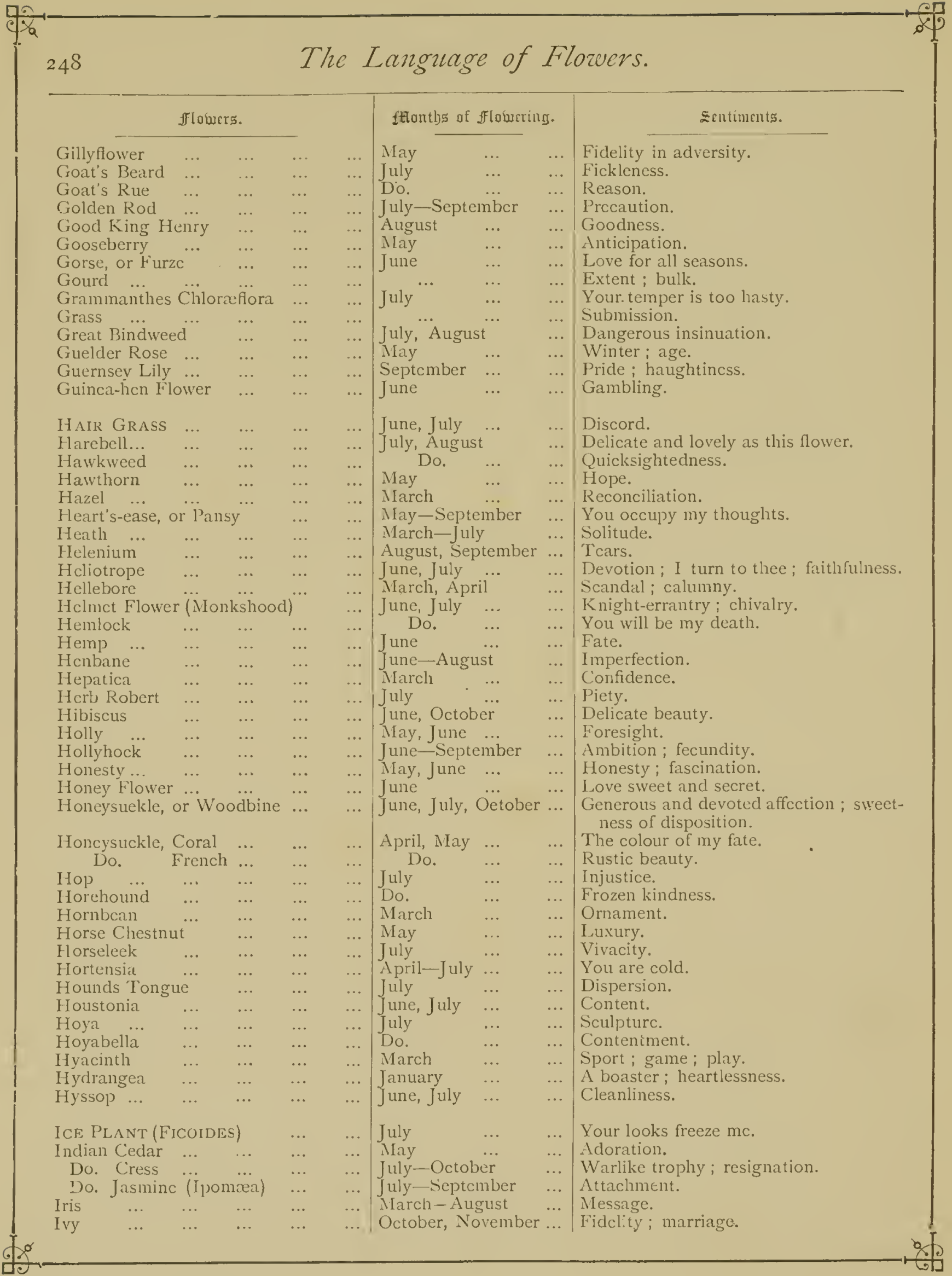




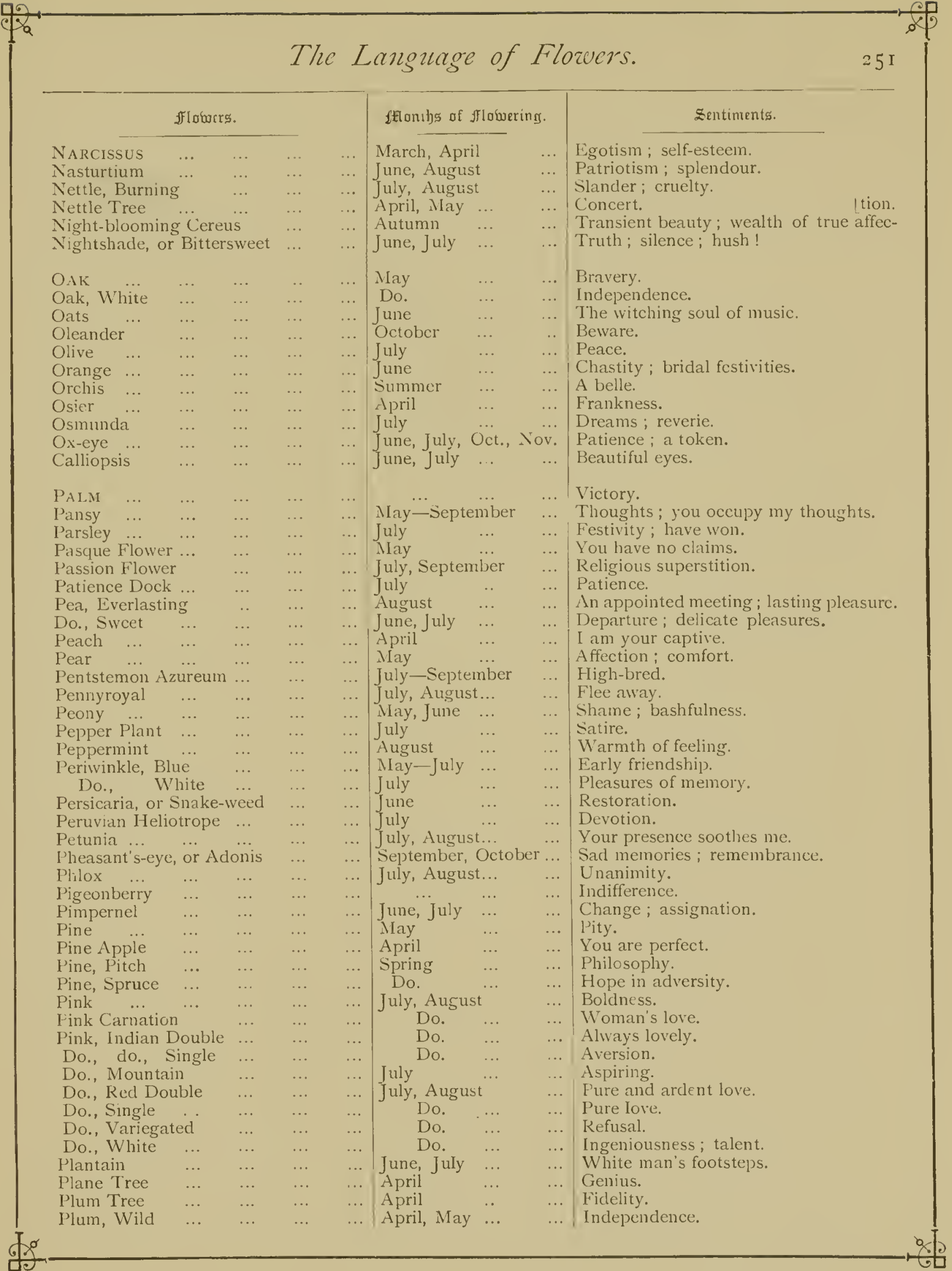




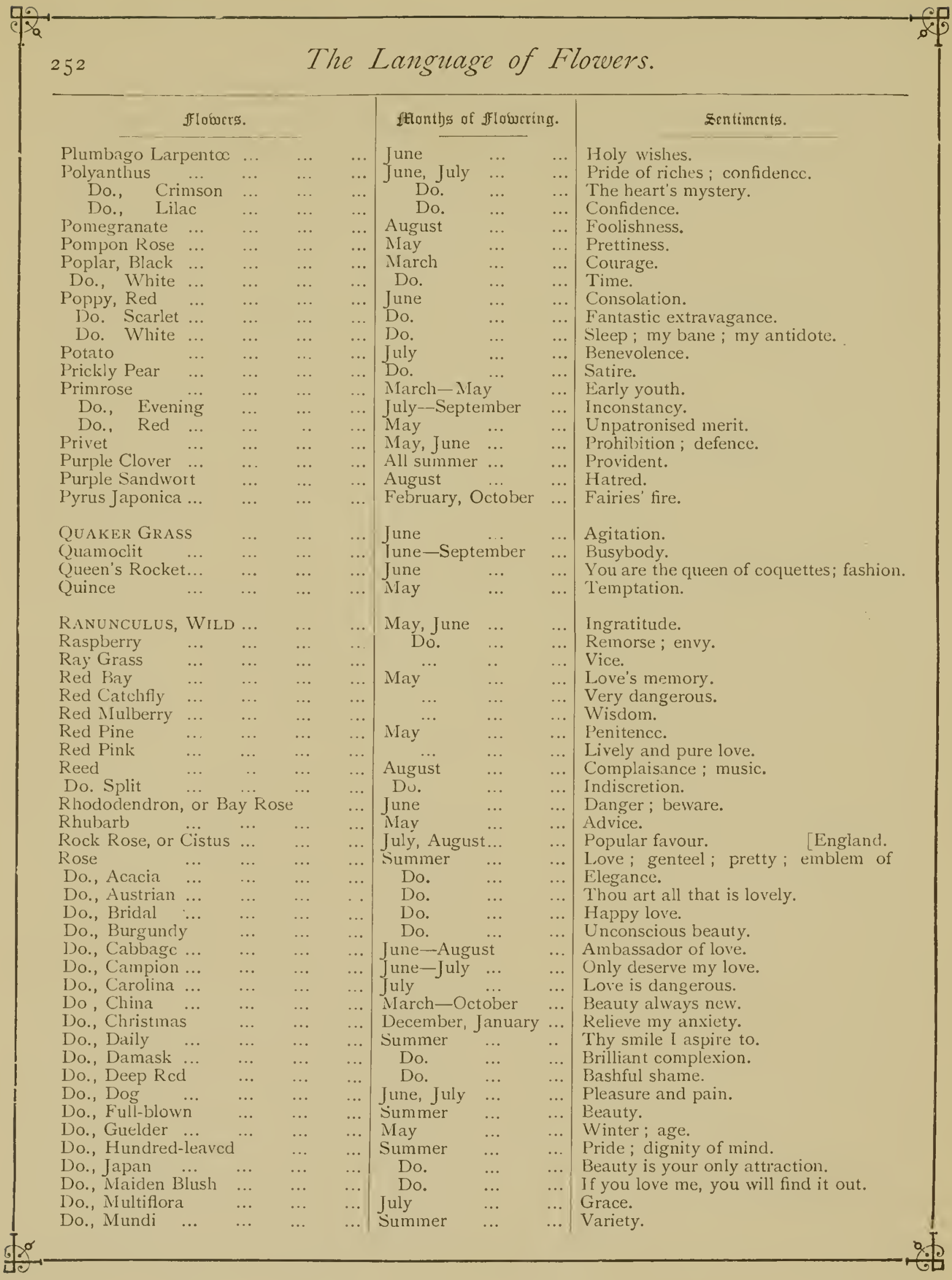




\section{The Language of Flowers.}

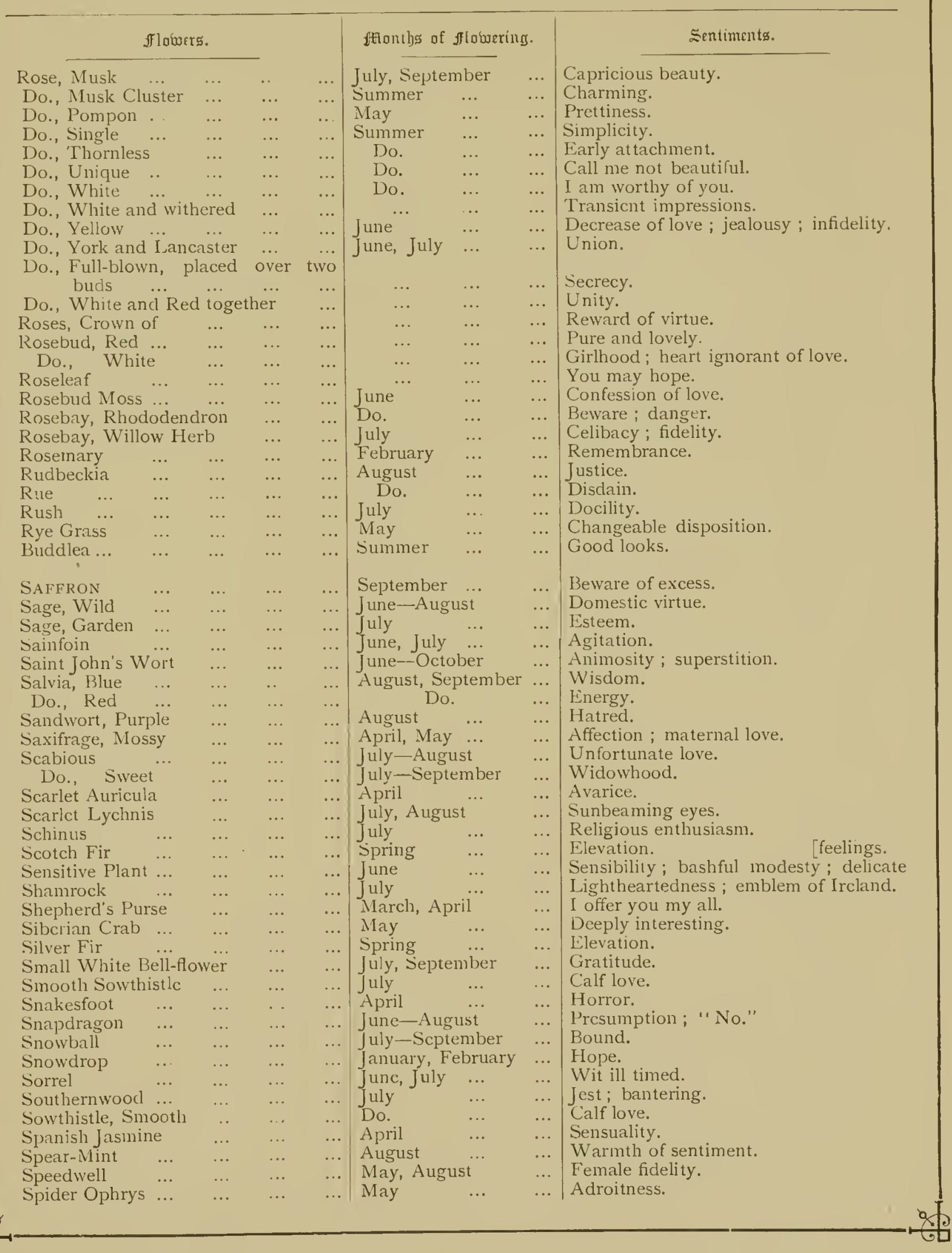




\begin{tabular}{|c|c|c|c|c|c|c|c|c|}
\hline \multicolumn{4}{|c|}{ fFlowుcts. } & \multicolumn{4}{|c|}{ ftontbs of flowering. } & Sentiments. \\
\hline Spiderwort & $\cdots$ & $\cdots$ & $\cdots$ & $\cdots$ & May, June & ... & & Esteem not love ; transient happiness. \\
\hline Spindle Tree & $\cdots$ & $\cdots$ & $\cdots$ & .. & May & $\cdots$ & .. & Your charms are engraven on my heart. \\
\hline Spiroca & $\cdots$ & $\cdots$ & $\cdots$ & $\cdots$ & April, May & $\cdots$ & .. & Uselcssness. \\
\hline Spruce Fir & $\cdots$ & $\cdots$ & $\ldots$ & .. & Spring & $\ldots$ & .. & Farewell. \\
\hline Squirting Cucu & mber & $\ldots$ & $\cdots$ & $\ldots$ & June, July & $\ldots$ & $\ldots$ & Critic. \\
\hline Star of Bethlel & em & $\cdots$ & $\cdots$ & $\ldots$ & Jume & $\cdots$ & $\cdots$ & Purity. \\
\hline Starwort & $\because$ & $\cdots$ & $\cdots$ & $\cdots$ & August, Scp & tember & $\cdots$ & Afterthought. [stranger. \\
\hline Starivort, Ame & rican & $\cdots$ & $\cdots$ & $\cdots$ & May-Octol & ber & $\cdots$ & Cheerfulness in old agc; welcome to a \\
\hline Stinging Nettle & & $\cdots$ & $\cdots$ & $\cdots$ & $\int_{J} u l y$, Augus & & $\cdots$ & Slander ; cruelty. \\
\hline Stitchwort & $\cdots$ & $\cdots$ & $\cdots$ & $\cdots$ & $\int \operatorname{anuary}-\int \mathrm{u}$ & uly & $\cdots$ & Captivating purity. \\
\hline Stock, or Gillyf & hower & $\cdots$ & $\cdots$ & $\cdots$ & $\int$ une--Augu & ust & $\cdots$ & Lasting beauty ; bonds of affection. \\
\hline Stock, Ten-wee & ek & $\cdots$ & $\cdots$ & $\cdots$ & May-Nove & ember & $\cdots$ & Promptness. \\
\hline Stonecrop & $\cdots$ & $\cdots$ & $\cdots$ & $\cdots$ & June, July & $\cdots$ & $\cdots$ & \\
\hline $\begin{array}{c}\text { Straw, Broken } \\
\text { Do., Whole }\end{array}$ & $\begin{array}{l}\cdots \\
\cdots\end{array}$ & $\begin{array}{l}\cdots \\
\cdots\end{array}$ & $\begin{array}{l}\cdots \\
\cdots\end{array}$ & $\begin{array}{l}\cdots \\
\cdots\end{array}$ & $\begin{array}{l}\cdots \\
\cdots\end{array}$ & $\begin{array}{l}\cdots \\
\cdots\end{array}$ & $\begin{array}{l}\cdots \\
\cdots\end{array}$ & $\begin{array}{l}\text { Kupture of a contract. } \\
\text { Union. }\end{array}$ \\
\hline Strawberry & $\cdots$ & $\cdots$ & $\ldots$ & $\cdots$ & May & $\ldots$ & $\ldots$ & Foresight ; perfect goodness. \\
\hline Strawberry Tre & e, or & Arbutu: & & .. & September, & October & r... & Esteem and love. \\
\hline Sunderv & $\cdots$ & $\cdots$ & $\cdots$ & $\cdots$ & July, Augus & & ... & Greed. \\
\hline Sunflower & $\cdots$ & $\cdots$ & $\cdots$ & $\cdots$ & July-Septer & mber & $\cdots$ & False riches. \\
\hline Do., Dwar & f & $\cdots$ & $\cdot \cdot$ & $\cdots$ & August, Sep & ptember & $\cdots$ & Adoration ; your devoted adorer. \\
\hline Swallow-wort & $\cdots$ & $\cdots$ & $\cdots$ & $\cdots$ & July & $\cdots$ & $\cdots$ & Medicine; cure for heartache. \\
\hline $\begin{array}{l}\text { Swcet Basil } \\
\text { Sweet Briar }\end{array}$ & $\begin{array}{l}\cdots \\
\cdots\end{array}$ & $\begin{array}{l}\cdots \\
\cdots\end{array}$ & $\begin{array}{l}\cdots \\
\cdots\end{array}$ & $\begin{array}{l}\cdots \\
\ldots\end{array}$ & July, Augus & st & $\cdots$ & $\begin{array}{l}\text { Good wislies. } \\
\text { Poetry; I wound to heal. }\end{array}$ \\
\hline $\begin{array}{l}\text { Sweet Briar } \\
\text { Sweet Flag }\end{array}$ & $\cdots$ & $\ldots$ & $\ldots$ & $\begin{array}{l}\cdots \\
\cdots\end{array}$ & $\begin{array}{l}\text { June, July } \\
\text { June }\end{array}$ & $\cdots$ & $\cdots$ & $\begin{array}{l}\text { Poetry; I wound to heal. } \\
\text { Fitness. }\end{array}$ \\
\hline & ... & $\ldots$ & $\ldots$ & $\cdots$ & & $\cdots$ & $\cdots$ & $\begin{array}{l}\text { Fitness. } \\
\text { Delicate pleasures ; departure. }\end{array}$ \\
\hline $\begin{array}{l}\text { Siveet Pea } \\
\text { Sweet Sultan }\end{array}$ & $\ldots$ & $\ldots$ & $\ldots$ & $\ldots$ & August & $\begin{array}{l}\cdots \\
\cdots\end{array}$ & $\begin{array}{l}\cdots \\
\cdots\end{array}$ & $\begin{array}{l}\text { Delicate pleasures; departure. } \\
\text { Felicity. }\end{array}$ \\
\hline Swect Willian & $\ldots$ & $\ldots$ & $\ldots$ & $\ldots$ & July & $\ldots$ & $\ldots$ & Gallantry. \\
\hline Sweet-scented & Tussila & age & .. & .. & March & $\cdots$ & $\cdots$ & You shall have justice. \\
\hline Sycamore & $\cdots$ & $\cdots$ & $\cdots$ & $\cdots$ & April & $\cdots$ & ... & Meet me. \\
\hline Syringa & $\cdots$ & $\cdots$ & $\cdots$ & $\cdots$ & May, June & $\cdots$ & $\ldots$ & Memory: \\
\hline Syringa, Caroli & & ․ & $\cdots$ & $\cdots$ & Do. & $\cdots$ & $\cdots$ & Disappointment. \\
\hline TAMARISK & & ... & ... & ... & June, July & $\cdots$ & $\ldots$ & Crime. \\
\hline Tansy, Wild & $\cdots$ & $\cdots$ & $\ldots$ & $\cdots$ & August & $\ldots$ & $\cdots$ & I declare war against you. \\
\hline Teasel & $\ldots$ & $\ldots$ & $\cdots$ & $\cdots$ & July & $\cdots$ & $\cdots$ & Misanthropy. \\
\hline Tendrils of clim & nbing 1 & plants & $\cdots$ & $\cdots$ & $\cdots$ & $\cdots$ & $\cdots$ & Lies. \\
\hline Ten-iveek Stocl & & $\cdots$ & $\cdots$ & $\cdots$ & May-Novel & ember & $\cdots$ & Promptness. \\
\hline 'Thistle & $\cdots$ & $\cdots$ & $\cdots$ & $\cdots$ & July & $\cdots$ & $\cdots$ & Austerity. \\
\hline Thistle, Scotch & $\cdots$ & $\cdots$ & $\cdots$ & $\cdots$ & July, Augus & & $\cdots$ & Retaliation ; emblem of Scotland. \\
\hline & & $\cdots$ & $\cdots$ & $\cdots$ & August & $\cdots$ & $\cdots$ & $\begin{array}{l}\text { Deceitful charms. } \\
\text { Severity }\end{array}$ \\
\hline $\begin{array}{l}\text { Thorn, Branch } \\
\text { 'Thrift }\end{array}$ & or & $\cdots$ & $\begin{array}{l}\cdots \\
\ldots\end{array}$ & $\cdots$ & July ${ }^{\cdots}$ Augus & st & $\cdots$ & $\begin{array}{l}\text { Severity. } \\
\text { Sympathy : mutual sensibility. }\end{array}$ \\
\hline $\begin{array}{l}\text { Thrift } \\
\text { 'Ihroatwort }\end{array}$ & $\cdots$ & $\begin{array}{l}\cdots \\
\cdots\end{array}$ & $\cdots$ & $\begin{array}{l}\cdots \\
\cdots\end{array}$ & $\begin{array}{l}\text { Juy, Augus } \\
\text { July }\end{array}$ & St $\ldots$ & $\begin{array}{l}\cdots \\
\cdots\end{array}$ & $\begin{array}{l}\text { sympatny ; mutual sensibility. } \\
\text { Neglected beauty. }\end{array}$ \\
\hline $\begin{array}{l}\text { Throatwort } \\
\text { Thyme }\end{array}$ & ... & $\ldots$ & $\ldots$ & $\begin{array}{l}\cdots \\
\ldots\end{array}$ & July & $\begin{array}{l}\cdots \\
\cdots\end{array}$ & $\begin{array}{l}\cdots \\
\cdots\end{array}$ & $\begin{array}{l}\text { Neglected Deauty. } \\
\text { Activity; courage. }\end{array}$ \\
\hline Thymer Flower & $\ldots$ & $\cdots$ & $\ldots$ & $\ldots$ & July -Septer & mber & $\begin{array}{l}\cdots \\
\cdots\end{array}$ & For once may pride befriend mc. \\
\hline Iraveller's Joy, & or $\mathrm{Cle}$ & ematis & $\ldots$ & $\ldots$ & August & $\ldots$ & $\ldots$ & Poverty; safety. \\
\hline Tree of Life & & $\ldots$ & $\ldots$ & ... & May & $\ldots$ & $\ldots$ & Old Age. \\
\hline Trefoil (Birdsfo & ot) & ... & ... & $\ldots$ & July, Augus & & ... & Revenge. \\
\hline Irillium Pictum & & $\cdots$ & $\ldots$ & $\cdots$ & May, June & ... & $\cdots$ & Mlodest beauty. \\
\hline Triptilion Spinc & osum & $\cdots$ & $\cdots$ & $\cdots$ & July & $\cdots$ & $\ldots$ & Be prudent. \\
\hline Truffle & $\cdots$ & $\cdots$ & $\cdots$ & $\ldots$ & I $\quad \ldots$ & $\cdots$ & $\cdots$ & Surprise. \\
\hline Trumpet Flowe & & $\cdots$ & $\cdots$ & .. & June & .. & .. & Separation ; fame. [lovely girl. \\
\hline Tuberose & $\cdots$ & $\cdots$ & $\cdots$ & $\cdots$ & August & $\cdots$ & .. & Dangerous pleasures; I have scen a \\
\hline Tulip & $\cdots$ & $\cdots$ & $\ldots$ & $\cdots$ & April & ... & ... & Fame. \\
\hline Do., Rcd & ... & ... & $\ldots$ & $\ldots$ & Do. & $\ldots$ & $\cdots$ & Declaration of love. \\
\hline 'Tulip 'Tree & $\cdots$ & $\cdots$ & $\cdots$ & $\cdots$ & June & $\cdots$ & $\cdots$ & Fame. \\
\hline Do., Variegate & & .. & $\cdots$ & $\cdots$ & April & $\cdots$ & $\cdots$ & Bcautiful eyes. \\
\hline Do., Yellow & $\cdots$ & ... & $\cdots$ & $\cdots$ & April, May & $\cdots$ & & Hopeless love. \\
\hline Turnip & $\cdots$ & ‥ & $\cdots$ & $\cdots$ & Spring & $\therefore$ & $\cdots$ & Charity. \\
\hline Tussilage, Sivee & et-scer & ted & $\cdots$ & & March, Apri & & & Justice shall be done you. \\
\hline
\end{tabular}


${ }_{25}{ }^{2} \quad$ The Language of Flowers.

\begin{tabular}{|c|c|c|c|c|c|c|c|}
\hline \multicolumn{4}{|c|}{ fflowers. } & & \multicolumn{2}{|l|}{ ftlontiss of fflowering. } & Sentiments. \\
\hline Xeranthemum & $\cdots$ & $\cdots$ & $\cdots$ & $\cdots$ & July ... & $\cdots$ & Cheerfulness under adversity. \\
\hline YARROW & & $\ldots$ & $\ldots$ & $\ldots$ & August & $\ldots$ & War. \\
\hline Yellow Carnatic & on & $\ldots$ & $\ldots$ & ... & Summer & $\ldots$ & Disdain. \\
\hline Yellow Day-lily & & ... & $\ldots$ & $\ldots$ & Do. & $\ldots$ & Coquetry. \\
\hline Yellow Gentian & & ... & $\ldots$ & $\ldots$ & June, July & ... & Ingratitude. \\
\hline Yellow Iris & & ... & $\ldots$ & $\ldots$ & July ... $\quad \ldots$ & $\cdots$ & Flame of love. \\
\hline Yellow Jasmine & & ... & $\ldots$ & $\cdots$ & July-September & .. & Grace and elegance. \\
\hline Yellow Lily & ... & $\cdots$ & $\ldots$ & $\ldots$ & Suminer $\quad \ldots$ & ... & Falsehood ; Gaiety. \\
\hline Yellow Rose & $\ldots$ & $\ldots$ & $\ldots$ & $\ldots$ & Do. & $\ldots$ & Infidelity. \\
\hline Yellow Violet & $\ldots$ & ... & $\ldots$ & $\ldots$ & Spring and autumn & $\ldots$ & Rustic liappiness. \\
\hline Yew $\quad \ldots$ & $\cdots$ & $\cdots$ & $\ldots$ & $\cdots$ & February $\quad \ldots$ & $\ldots$ & Sadness ; mourning. \\
\hline $\begin{array}{l}\text { ZEPHYR FLOWF } \\
\text { Zinnia }\end{array}$ & $\begin{array}{l}\mathrm{ER}, \\
\cdots\end{array}$ & in & & & $\begin{array}{l}\text { March--May } \\
\text { June, July }\end{array}$ & $\begin{array}{l}\cdots \\
\cdots\end{array}$ & $\begin{array}{l}\text { Expectation; sickness. } \\
\text { Thoughts of absent friends. }\end{array}$ \\
\hline
\end{tabular}

\section{P A R T II.}

\section{SENTIMENTS, AND THEIR REPRESENTATIVE FLOWERS.}

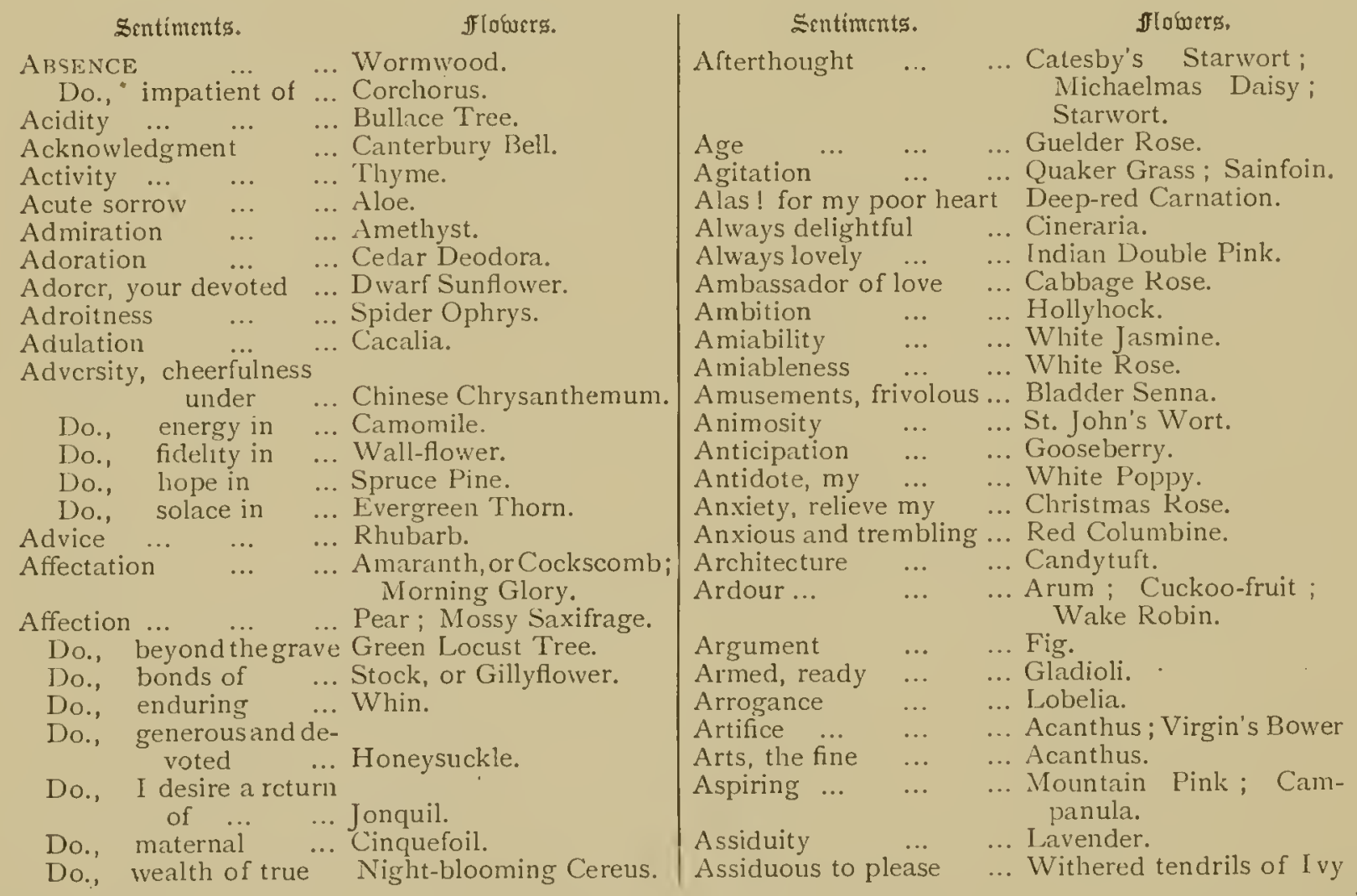




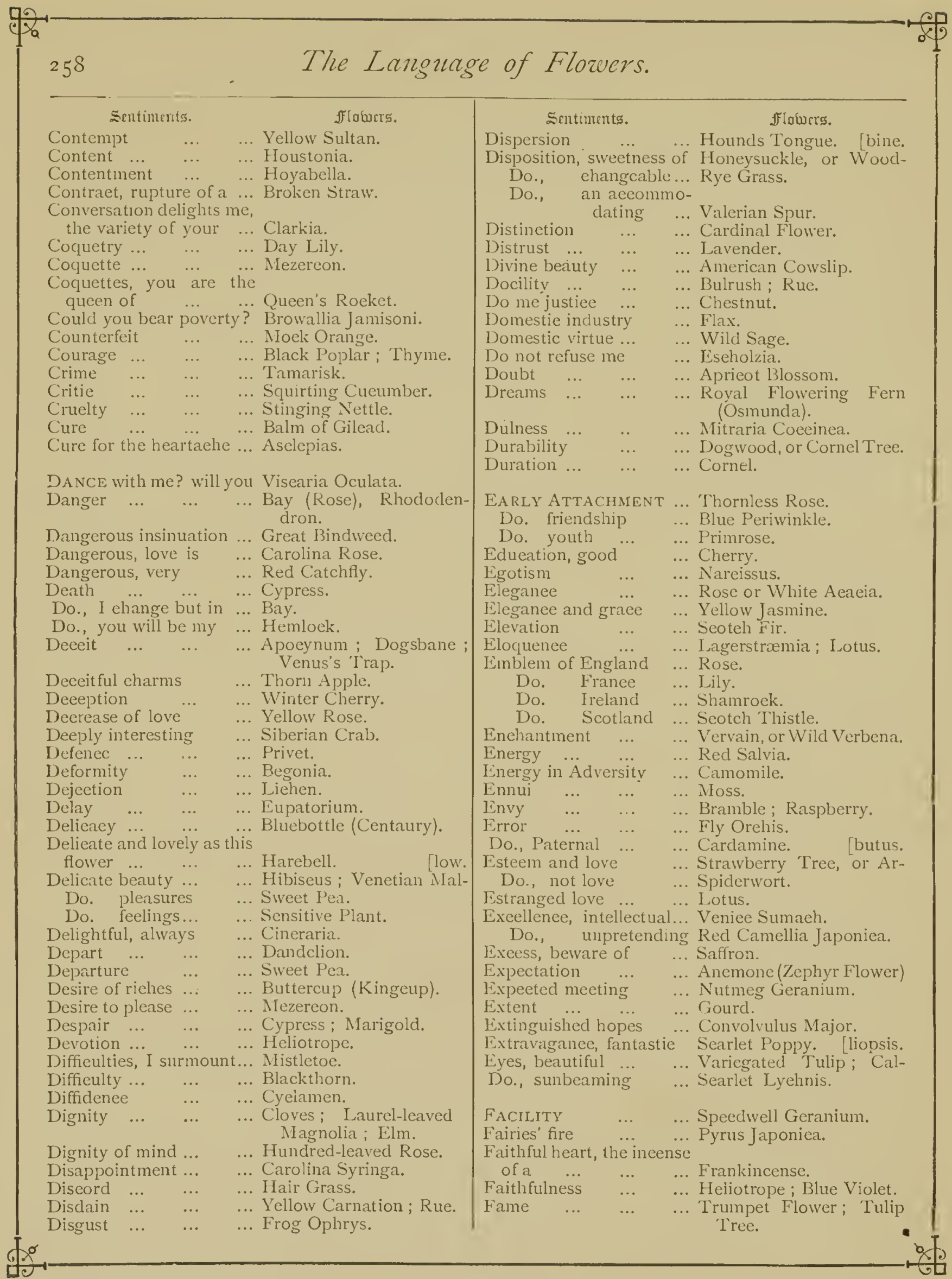


Falsehood

Fantastic extravagance... Scarlet Poppy.

Farewell ... ... ... Michaelmas Daisy ; Sipruce Fir.

Fascination $\quad$.. ... Fern; Honesty.

Fashion ... ... ... Qucen's Rocket.

Fate $\quad \ldots . \quad \ldots . \quad \ldots$. Flax; Hemp.

Do., the colour of my ... Coral Honeysuckle.

Favour, bridal ... ... Ivy Geranium.

Do., popular ... ... Cistus, or Rock Rose.

Fecundity $\quad \ldots . \quad \ldots$ Hollyhock.

Fecling, warmth of ... Peppermint.

Feelings, delicate

Felicity ... ...

Female fidelity $\ldots$

Feminine modesty

Festivities, Bridal

Festivity. ... ...

Ficlileness $\quad .$.

... Pink Larkspur

.... Ivy; Willow Herb; Lemon ; Rosebay; Plum 'Tree.

Do., female ... ... Speedwell.

Do., in adversity $\ldots$ Wall-flower,

Filial love $\quad . . \quad$... Virgin's Bower.

Fine arts, the $\ldots . \quad \ldots$ Acanthus.

Fitness $\ldots \quad \ldots$... Sweet Flag.

Flame $\quad \ldots \quad \ldots . \quad \ldots$ Fleur-cle-lis

Flame of Love ... ... Yellow Iris.

Flattery ... $\quad . . . \quad \ldots$ Venus's Looking-glass.

Flee away $\quad$... $\quad$... Pennyroyal.

Folly $\quad . . \quad \ldots . \quad \ldots$. Columbine.

Foolishness $\quad . . \quad$... Pomegranate; Wild Vine.

Footsteps, white man's Plaintain.

Foppery ... ... ... Amaranth, or Cockscomb

Foresight $\quad \ldots \quad \ldots$. ... Holly ; Strawberry.

Forgetfulness $\quad \ldots \quad$... Moonwort.

Forget me not $\ldots$... Forget-me-not; Mouseear, or Scorpion Grass.

Forsaken ...

. Garden Anemone; Laburnum; Lilac; Willow.

Fortitude

Dipteracanthus Spectabilis.

Fortune, I offer you

France, emblem of

Frankness

of Calceolaria.

... Day Lily.

.. Osier.

Frecze me, your looks ... Ice Plant (Ficoides).

Friends, beware of false Franciscea Latifolia.

Friendship $\quad \ldots . \quad \ldots$ Acacia.

Do., early ... $\quad \ldots$... Blue Periwinkle.

Do., true ... ... Oak-leaved Gcranium.

Do., unchanging ... Arbor Vita.

Frivolity ... ... ... London Pride.

Frivolous amusements ... Bladder Senna.

Frown will kill me, thy... Currant.

Frozen kindness ... ... Horehound.

Frugality ... ... ... Chicory; Endive.

\section{Sentiments.}

Garety ... ... ... Yellow Lily ; Butterfly Orchis.

Gallantry $\quad$... ... Sweet IVilliam.

Gambling $\quad .$. ... Guinca-hen Flower.

Game $\quad \ldots \quad \ldots \quad \ldots$ Hyacinth.

Generous and clevotcd affection $\quad . . \quad$... Honeysuckle, or Woodbine.

Genius $\quad . .6 \quad \ldots \quad$... Plane Trec.

Do., modest ... ... Creeping Cereus.

Genteel ... ... ... Rose.

Gentility ... ... ... Com Cockle

Girlhood ... ... ... White Rosebud.

Girl, I have seen a lovely Tuberose.

Gladness ... ... ... Myrrh.

$\begin{array}{lllll}\text { Glory } & \ldots & \ldots & \ldots & \text {... Bay Tree ; Daphne ; }\end{array}$

Laurel

Go, let me $\quad . . \quad$... Butterfly W'eed.

Good education ... ... Cherry.

Good looks $\quad . . . \quad \ldots$ Buddiea.

Good nature $\quad \ldots \quad \ldots$ White Mulberry.

Good, there is no unalloyed ... $\quad \ldots \quad$... Lapageria Rosea.

Goodness $\quad \ldots . \quad \ldots$ Good King Henry ; Mler-

Do., perfect ... Strawberry.

Gossip $\quad \ldots \quad \ldots \quad \ldots$ Cobœa.

Grace $\quad \ldots \quad \ldots . \quad \ldots$ Mlultifiora Rose.

Do., and clegance ... Yellow Jasmine.

Do., matronly $\quad$... Cattleya Pineli.

Do., winning ... ... Cowslip.

Grandeur $\quad \ldots . \quad \ldots$ Ash 'Tree.

Gratitude $\quad . . . \quad \ldots$ Agrimony ; Canterbury bell ; Small Whitc Bellflower.

Greed $\quad . .6 \quad \ldots \quad \ldots$ Sundew.

Grief $\quad \ldots \quad \ldots \quad \ldots$ Aloe; Marigold.

Happiness $\quad$... ... Mudivort; Mugwort.

Do., momentary... Virginian Spiderwort.

Do., return of ... Lily of the Valley.

Do., rural $\quad$... Yellow Violet.

Do., transient ... Spiderwort.

Happy, I'm too ... … Cape Jasmine.

Do., may you be ... Volkameria.

Happy love ... ... Bridal Rose.

Hardiness $\quad$... $\quad$... Cranberry.

Haste, makc $\quad \ldots . \quad \ldots$ Dianthus.

Hasty, your temper is too Grammanthes

Hatred ... ... ... Basil.

Haughtiness ... ... Guernsey I.ily ; Purple

Have won

Heal, I wound to $\quad$... Eglantine, or Sweet Brial".

Heartache, cure for the... Asclepias.

Heart! alas, for my poor Deep-red Carnation.

Do., ignorant of love... White Rosebud.

Do., purity of ... White Water-lily.

Do., the incense of a faithful ... Frankineense.

Heart's mystery, the ... Crimson Polyanthus. 


\section{The Language of Flowers.}

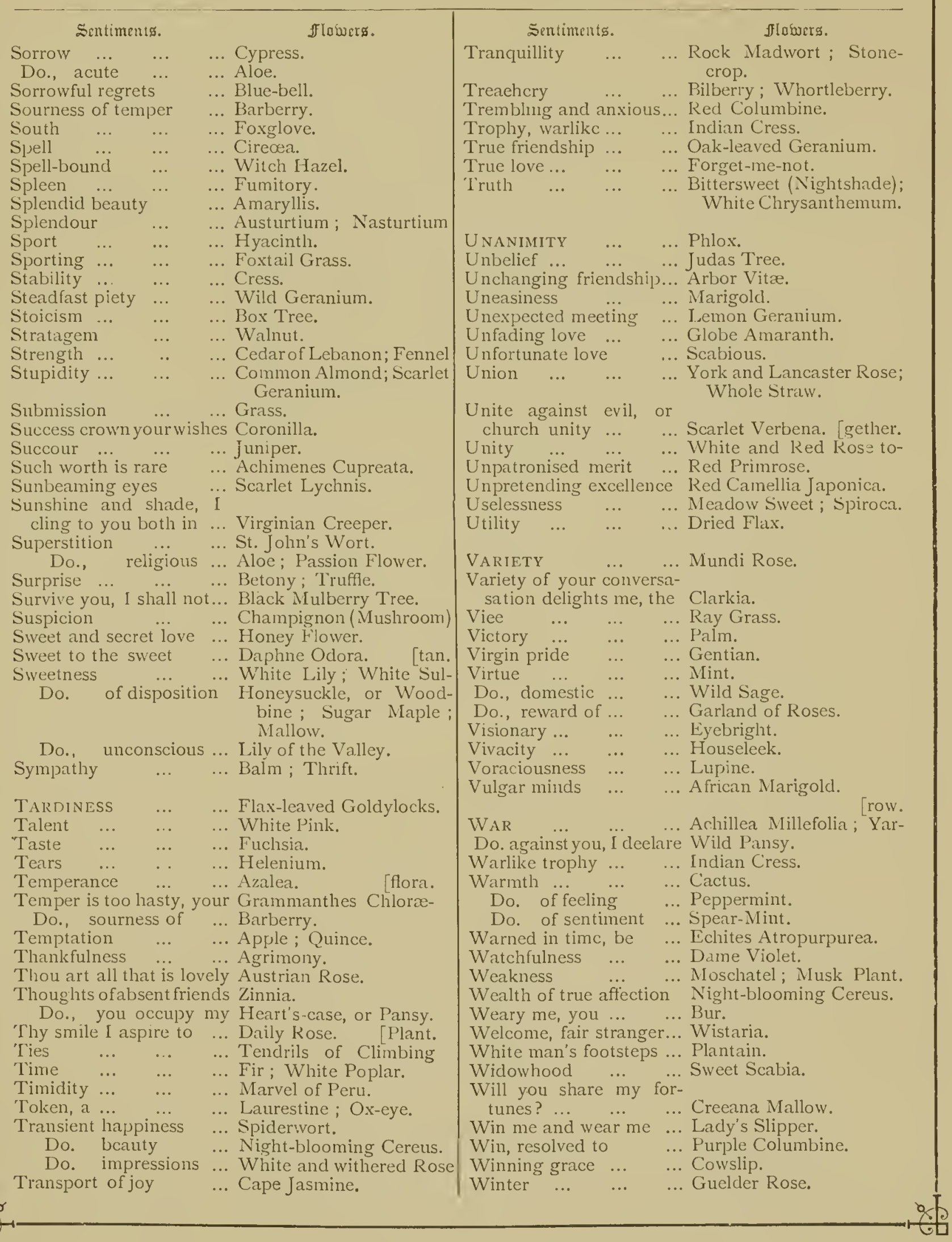




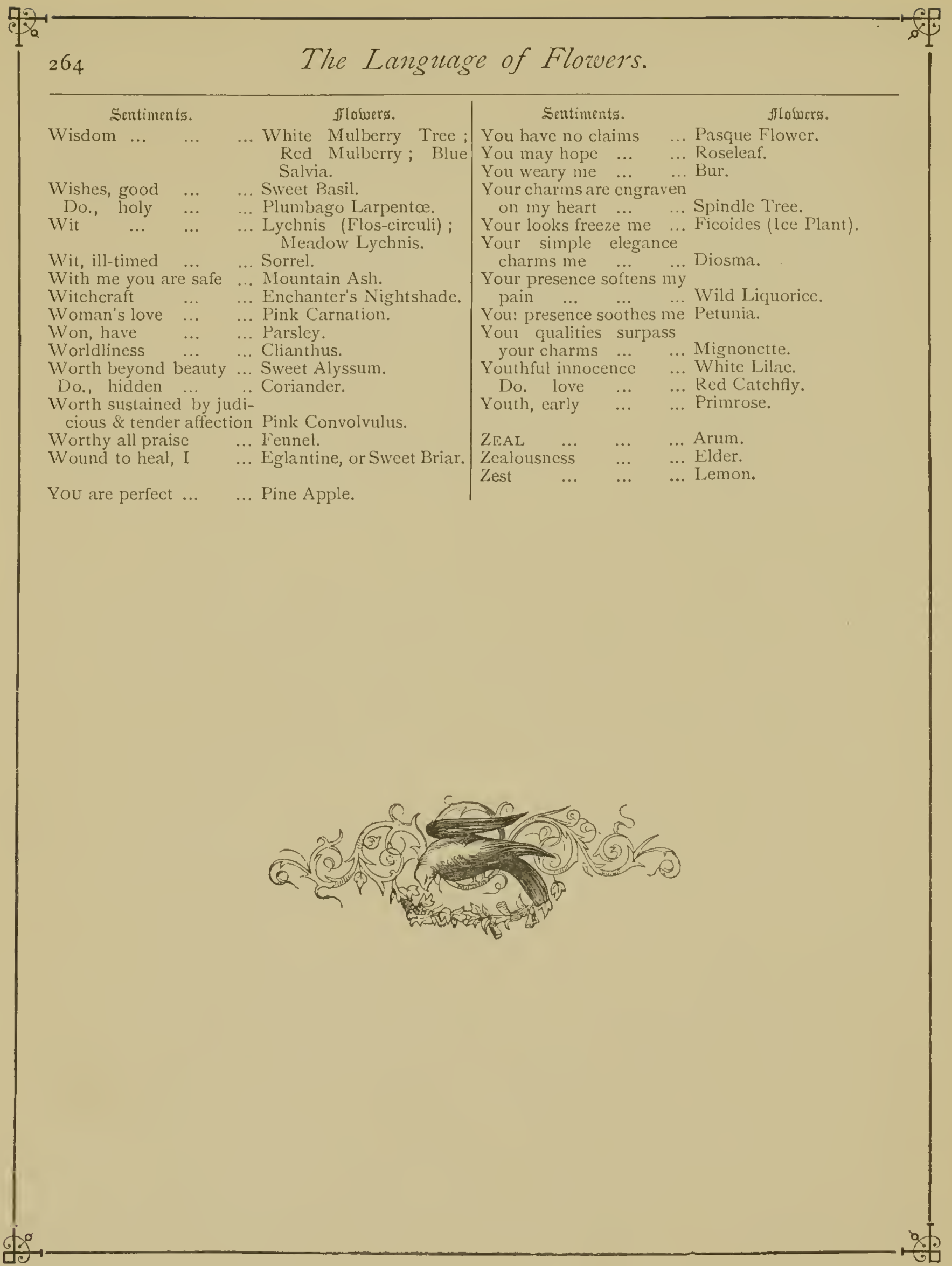




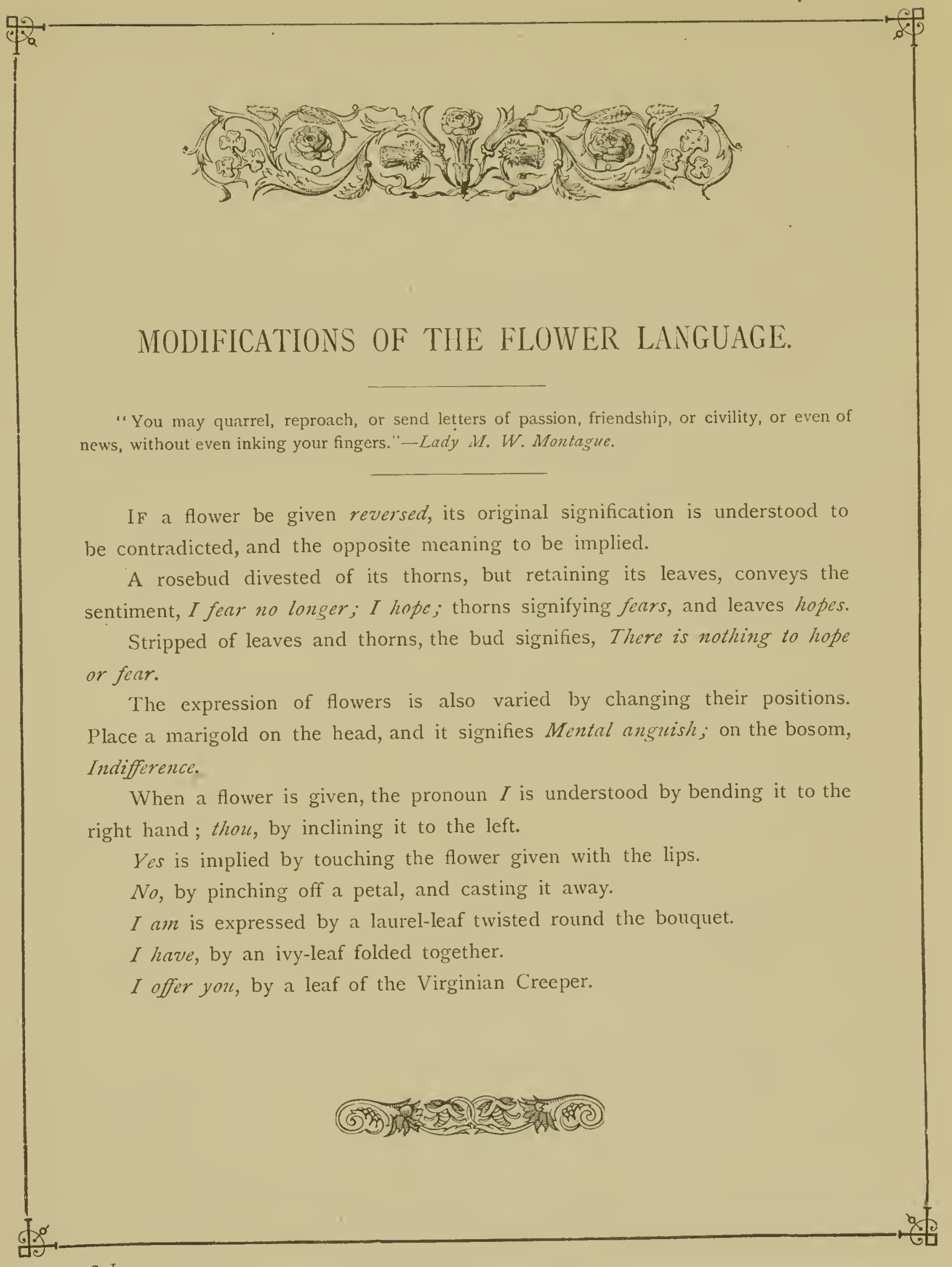

2 I 


\section{BOUQUETS AS EXAMPLES.}

Be temperate in your taste.

I. Tempcrance . . Azalea.

2. Taste . . . . Fuchsia.

Meet me to-night; do not forget.

I. Meet me . . . : Sycamore.

2. To-night . . . . Night Convolvulus.

3. Do not forget . . Forget-me-not.

May maternal love protect your early youth in innocence and joy.

I. Maternal love . . Mossy Saxifrage.

2. Protect. . . . . Bearded Crepis.

3. Early youth . . . Primrose.

4. Innocence . . . Daisy.

5. Joy . . '. . . Wood Sorrel.

Remember our rendezvous, but beware of a false friend.

I. Remembrance . . Rosemary.

2. Rendezvous . . . . Chickweed.

3. Beware of false friends. Franciscea Latifolia.

Do not refuse to come down and comfort my solitude.

I. Do not refuse . . Eschcolzia.

2. Come down . . . Jacob's Ladder.

3. Comfort . . . Pear Tiee.

4. Solitude . . . Heath.

I am docile and dejected, do not refuse me.

x. Docile.. . . . Kush. .

2. Dejected . . . . Lichen.

3. Do not refuse . . Carrot Flower.

Let the bonds of marriage unite us.

I. Bonds . . . . . Convolvulus.

2. Marriage . . . . Ivy.

3. Unite us . . . . A fero whole Straws.

My fortitude forsook me on your refusal to be mine.

I. Fortitude . . . . Dipteracanthus Spec-

2. Forsaken . . . Laburmum. [tabilis.

3. Refusal . . . . Striped Carnation.

4. Be mine . . . . . Four-leaved Clover.

I hope you may be happy, and offer you pecuniary aid.
I. Hope
Flowering Almond.
2. May you be happy . Volkameria.
3. Offer pecuniary aid. Calceolaria.

Our unexpccted mecting left but transient impressions.

Answer-Vulgar minds soon forget.

I. Unexpected meeting - Lemon Geranium.

2. Transient impressions . Withered White Rose.

3. Vulgar minds . . . African Marigold.

4. Forgetfulness . . . Moonzwort.

I love to disappoint your curiosity.

I. Love . . . . . Red Rose.

2. Disappointment . - Caralina Syringa.

3. Curiosity . . . . Sycamore.

Your affectation and deceit I disdain.

I. Affectation . . Cockscomb Amaranth.

2. Deceit . . . . Fly-trap.

3. Disdain . . . Yeliow Carnation.

I sorrowfully regrct your indifference, and am melancholy on account of your coldness.

I. I sorrowfully regret Blue-bells.

2. Indifference . . . Mustard Seed.

3. Melancholy . . . Dead leaves.

4. Coldness . . . . Agnus Castus.

Your humility and amiability have won my love.

I. Humility . . . . Broom.

2. Amiability . . . White Fasmine.

3. Have won . . . Paisley.

4. Love . . . . Myrtle.

Your patriotism, courage, and fidelity merit everlasting remembrance.

I. Patriotism . . . . Nasturtium.

2. Courage . . . Oak leaves.

3. Fidelity . . . Heliotrope.

4. Everlasting romembrance Immortelles.

Beware of deceit. Danger is near. Depart.

I. Beware . : . . Oleander.

2. Deccit . . . . Fly-trap.

3. Danger is near . . Rhododendron.

4. Depart . . . . Dandelion.

By foresight you will surmount your difficulties.

I. Foresight . . . . Holly.

2. You will surmount your

difficulties . . Mistletoe. 


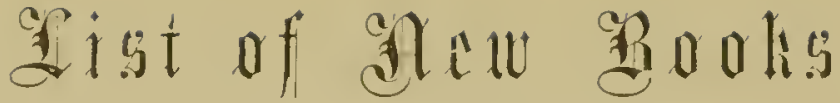 \\ JUST PUBLISHED BY \\ MARCUS WARD \& CO.}

Floral Poetry and the Language of Flowers. A collection of choice poems on Flowers, with most complete Indexes to the Language of Flowers, and eight exquisite Chromographs. Small quarto, cloth elegant, gilt edges, io, 6 .

English Echoes of German Song. Translated by Dr. R. E. Wallis, Dr. J. D. Morell, and F. D'Anvers. Edited by N. D'ANvers. With Twelve beautiful Engravings on Steel. Small quarto, cloth elegant, gilt edges, iol6.

Childhood a Hundred Years Ago. By Sarah Tytler, Author of "Papers for Thoughtful Girls," \&c., \&c. With Six Chromos, after Paintings by Sir Joshua REynolds. Small quarto, cloth elegant, gilt edges, io/6.

Landseer's Dogs and their Stories. By SARAH TyTLER, Author of "Childhood a Hundred Years Ago," \&c., \&c. With Six Chromos, after Paintings by Sir Edwin Landseer. Small quarto, cloth elegant, gilt edges, Io!6. Stories of Roman History for the Little Ones. By CharLotTe M. YONGE, Author of "Stories of Greek History for the Little Ones," \&c. Illuminated Frontispiece and Title-page, and numerous Woodcuts. Square octavo, cloth extra, bevelled boards, gilt edges, $6 /-$.

Last Cruise of the Ariadne. By S. Whitchurch SADLER, Author of "The Ship of Ice," "Perilous Seas," \&c. Coloured Frontispieçe and Illustrations. Crown octavo, cloth extra, 5/-.

Three Years at Wolverton: a Public School Story. By a Wolvertonian. Coloured Frontispiece and Illustrations. Crown octavo, cloth extra, 5 i-.

India, Historical and Descriptive. With an Account of the Sepoy Mutiny of 1857-58, by C. H. EDEN. 66 Illustrations, Map, and Coloured Frontispiece. Crown octavo, cloth extra, 3/6.

Notes of Travel in Egypt and Nubia. By J. L. STEPhens. Revised and enlarged, with an Account of the Suez Canal. 7 I Illustrations, Map, and Coloured Frontispiece. Crown octavo, cloth extra, 3/6.

Fairy Land: Tales and Legends of Dwarfs, Fairies, WaterSprites, Elves, \&c. From the German of Villamaria. 25 Illustrations and Coloured Frontispiece. Crown octavo, cloth extra, 3/6.

Robinson Crusoe. By DANiel DE FoE. A new and beautiful edition, with numerous Illustrations, Coloured Frontispiece and Title. Crown octavo, cloth extra, $3 / 6$.

The Vicar of Wakefield. By OLiver Goldsuith. Numerous Illustrations, Coloured Frontispiece and Title. Crown octavo, cloth extra, 3:6. 
Mildred's Mistake. A Still-Life Study. By F. Levien, Author of "Little Ada's Jewels," \&c. Coloured Frontispiece and Illustrations. Small octavo cloth extra, $2 / 6$.

Kaspar and the Seven Wonderful Pigeons of Wurzburg. By Julia Goddard. Coloured Frontispiece and Illustrations. Small octavo, cloth extra, $2 / 6$.

Nanny's Treasure. Nineteen full-page Illustrations and Coloured Frontispiece. Small octavo, cloth extra, $2 / 6$.

The Little Head of the Family. Fourteen full-page Illustrations and Coloured Frontispiece. Small octavo, cloth extra, $2 / 6$.

Where the Rail Runs Now: a Story of the Coaching Days. By F. Frankfort Moore. With Illustrations. Small octavo, cloth extra, 26.

Dobbie and Dobbie's Master: a Peep into the Life of a very little Man. By N. D'Anvers, Author of "Little Minnie's Troubles," \&c. With Illustrations. Small octavo, cloth extra, $2 / 6$.

Animals of the Farm: their Structure and Physiology. A Handbook for Agricultural Students and Farmers. By JoHN F. HongES, M.D., F.C.S., \&c. Second Edition, revised by the Author. Numerous Illustrations. Small octavo, cloth, $2 / 6$.

Aunt Charlotte's Stories of Bible History for the Little Ones.

By C. M. Yonge. School Edition. Nurnerous Illustrations. Neatly bound in cloth, $2 /$.

Wildflower Win: the Journal of a Little Girl. By Kathleen Knox. Numerous Illustrations. Cloth extra, i/6.

My Dolly. By H. Rutherfurd Russell, Author of "Tom," "Tom Seven Years Old," \&c. Coloured Frontispiece and Numerous Illustrations. Cloth extra, $\mathrm{i} / 6$. Language and Poetry of Flowers. Pocket Edition, Illustrations in Go!d and Colours. Cloth extra, $1 /$-.

\section{T玒E PRESS.}

Japan, Historical and Descriptive. Map and numerous Illustrations. Uniform with "India, Historical and Descriptive." Crown octavo, cloth extra, 3'6.

The Mythology of Greece and Rome, with special reference to its use in Art. From the German of O. Seemann. Edited by G. H. BIAnchI, B.A., late Scholar of S. Peter's College, Cambridge; Brotherton Sanskrit Prizeman, 1875. 64 Illustrations.

Bards and Blossoms. With Twelve Floral Plates, illuminated in Gold and Colours. By F. E. Hulie, F.L.S., F.S.A., Marlborough College; Author of

"Plants: their Natural Growth and Ornamental Treatment," \&c.

A complete Catalogue of Marcus Ward \& Co.'s Publications may be had, free by post, on application. 

